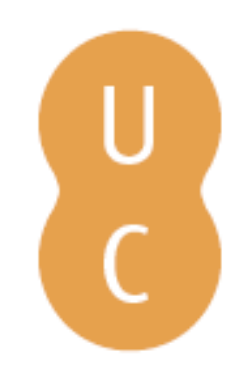

\title{
nombalina
}

\section{Intrigas palacianas nos "Annales" de Tácito: processos e tentativas de obtenção de poder no principado de Tibério}

\begin{tabular}{ll} 
Autor(es): & Nobre, Ricardo \\
Publicado por: & $\begin{array}{l}\text { Centro de Estudos Clássicos e Humanísticos; Imprensa da Universidade } \\
\text { de Coimbra }\end{array}$ \\
$\begin{array}{l}\text { URL } \\
\text { persistente: }\end{array}$ & URI:http://hdl.handle.net/10316.2/2375 \\
DOI: & DOI:http://dx.doi.org/10.14195/978-989-8281-39-5 \\
Accessed : & 26-Apr-2023 14:29:56 \\
\hline
\end{tabular}

A navegação consulta e descarregamento dos títulos inseridos nas Bibliotecas Digitais UC Digitalis, UC Pombalina e UC Impactum, pressupõem a aceitação plena e sem reservas dos Termos e Condições de Uso destas Bibliotecas Digitais, disponíveis em https://digitalis.uc.pt/pt-pt/termos.

Conforme exposto nos referidos Termos e Condições de Uso, o descarregamento de títulos de acesso restrito requer uma licença válida de autorização devendo o utilizador aceder ao(s) documento(s) a partir de um endereço de IP da instituição detentora da supramencionada licença.

Ao utilizador é apenas permitido o descarregamento para uso pessoal, pelo que o emprego do(s) título(s) descarregado(s) para outro fim, designadamente comercial, carece de autorização do respetivo autor ou editor da obra.

Na medida em que todas as obras da UC Digitalis se encontram protegidas pelo Código do Direito de Autor e Direitos Conexos e demais legislação aplicável, toda a cópia, parcial ou total, deste documento, nos casos em que é legalmente admitida, deverá conter ou fazer-se acompanhar por este aviso.

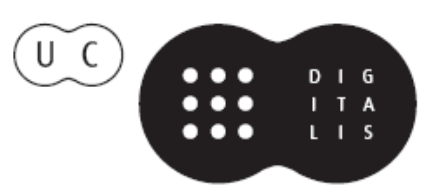




\section{intrigas palacianas nos Annales de Tácito}

processos e tentativas de obtenção de poder no principado de Tibério

Ricardo Nobre 


\section{Ricardo Nobre}

(Universidade de Lisboa e Universidade Aberta)

\section{Intrigas Palacianas nos Annales de Tácito}

Processos e tentativas de obtençâo de poder no Principado de Tibério 
Todos os volumes desta série são sujeitos a arbitragem científica independente.

Autor: Ricardo Nobre

Título: Intrigas Palacianas nos AnNales de Tácito -

PROCESSOS E TENTATIVAS DE OBTENÇÃo DE PODER NO PRINCIPADO DE TIBÉRIO

\title{
Editor: Centro de Estudos Clássicos e Humanísticos IMPRENSA DA UNIVERSIDADE DE COIMBRA
}

\author{
Coordenador Científico do Plano de Edição: Maria do Céu Fialho \\ Conselho Editorial: José Ribeiro Ferreira, Maria de Fátima Silva, \\ Francisco de Oliveira, Nair Castro Soares \\ Director técnico da ColecÇão: Delfim F. LeÃo \\ Concepçấo gráfica e paginação: Elisabete Cação, Nelson Ferreira, \\ RODOLFO LOPES
}

\section{OBRa REALIZADA No ÂMBITO DAS ACTIVIDADES DA UI\&D \\ Centro de Estudos Clássicos e Humanísticos}

\author{
Universidade de CoImbra \\ FACUlDADE DE LETRAS \\ TEL.: 239859981 | FAX: 239836733 \\ 3000-447 CoImbra
}

ISBN: 978-989-8281-38-8

ISBN Digital: 978-989-8281-39-5

Depósito Legal: 312189/10

Obra Publicada com o Apoio de:

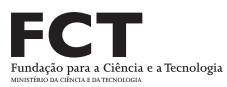

$\mathrm{POCI} / 2010$

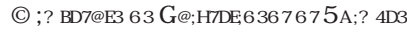

(C) Classica Digitalia Vniversitatis Conimbrigensis

(C) Centro de Estudos Clássicos e Humanísticos da Universidade de Coimbra

C Centro de Estudos Clássicos da Universidade de Lisboa
\end{abstract}

Reservados todos os direitos. Nos termos legais fica expressamente proibida a reprodução total ou parcial por qualquer meio, em papel ou em edição electrónica, sem autorização expressa dos titulares dos direitos. É desde já excepcionada a utilização em circuitos académicos fechados para apoio a leccionação ou extensão cultural por via de e-learning. 


\section{ÍNDICE}

Palavras Prévias

Prefácio $\quad$ V

Professora Cristina Pimentel

$\begin{array}{lr}\text { INTRODUÇÃO } & 1\end{array}$

Capítulo I - A ConstruÇÃo e as Fronteiras da Instituiçấo Literária:

Tácito, Literatura e História 9

1. História e Literatura 12

2. Historiografia Antiga 18

3. O Plano do Historiador $\quad 25$

3.1 As Fontes dos Annales $\quad 30$

3.2 Fidelidade às fontes $\quad 33$

Capítulo II - AvgVtatae Conscientia, CAESARIS Favor 35

1. Augusto: ESTABelecimento De uM MOdelo Retórico 42

2. Eliminação da descendênCia de Augusto $\quad 51$

3. Germânico 61

3.1 O herói da Germânia $\quad 65$

3.2 O herói da História $\quad 79$

4. Pisão e Plancina. A morte de Germânico 85

4.1 A morte de Germânico $\quad 90$

4.2 A vingança de Germânico $\quad 98$

Capítulo III - Continvae Accusationes, Fallaces Amicitiae 113

1. Amizades falsas e perniciosas: Libão Druso 120

2. Da morte de Druso ao isolamento de Tibério 136

3. Ataque e destruiçấo da Casa de Germânico 153

3.1 A perseguição de Tício Sabino $\quad 155$

3.2 A casa de Germânico 162

4. Liberdade de expressão: Cremúcio Cordo 165

$\begin{array}{lr}\text { ConClusấo } & 173\end{array}$

$\begin{array}{lr}\text { BIBLIOGRAFIA } & 179\end{array}$

$\begin{array}{ll}\text { INDEX NOMINVM } & 201\end{array}$

$\begin{array}{ll}\text { INDEX LOCORVM } & 205\end{array}$ 
Para os meus pais 


\section{Palavras Prévias}

A obra que agora se publica é resultado da minha investigação no âmbito do Mestrado em Estudos Clássicos, com especialização em Literatura Latina. A dissertação, que foi apresentada à Faculdade de Letras da Universidade de Lisboa e orientada pela Professora Doutora Maria Cristina de Castro-Maia de Sousa Pimentel, foi defendida a 13 de Novembro de 2008 (tendo sido arguida pelo Professor Doutor Francisco de Oliveira). A distância temporal que nos separa dessa data justificou a necessidade de algumas actualizaçóes bibliográficas, que provam que os estudos tacitianos atravessam uma época de assinalável interesse (recorde-se que acaba de vir a lume o The Cambridge Companion to Tacitus, editado por A. J. Woodman e com a colaboração dos principais entendidos na obra do historiador latino). Além disso, a versão que agora se publica na já prestigiada colecção Classica Digitalia beneficia de uma nova conclusão e, resultado de uma cuidada revisão (feita com a colaboração da Ana Filipa Silva e do J. Filipe Ressurreição), nela se evita a repetição de algumas gralhas e erros da primeira versão.

Cabe aqui ainda uma nota sobre a edição dos Annales adoptada: é a da Oxford Classical Texts (de 1906), preparada por C. D. Fisher, não só por ser a edição utilizada na elaboração do Oxford Latin Dictionary, como por ter vindo a ser considerada como "meritorious" e com poucos "obvious demerits" (Goodyear 1972 16 e 20 n.1). Consciente de que o texto estabelecido em 1906 tem alguns problemas, houve a necessidade de divergir dele em alguns casos, assinalando-os devidamente (versôes alternativas 
ou pontuação diferente ${ }^{1}$ ); foi ainda adoptada a grafia $u$ em vez de $v$ e a divisão em parágrafos é a que comummente se utiliza em trabalhos académicos sobre Tácito, originária das ediçóes da Teubner.

As referências dos passos remetem para livros, capítulos e parágrafos dos Annales, salvo quando indicada a obra por meio de abreviaturas de autores e títulos, de harmonia com as consagradas pelo Oxford Latin Dictionary. Todas as datas são da nossa era, a menos que o contrário seja indicado. Os nomes próprios surgem em português, seguindo, naturalmente, o Vocabulário da Língua Portuguesa de Rebelo Gonçalves; quando náo contemplados nessa obra, a sua transposição para português obedeceu aos preceitos adequados.

Dirijo ainda palavras de sincero agradecimento ao Professor Doutor Delfim Leão, director técnico da colecção Classica Digitalia, ao Professor Doutor Francisco de Oliveira, ao Professor Doutor Arnaldo do Espírito Santo e à Professora Doutora Maria Cristina de Sousa Pimentel, por terem possibilitado esta publicação.

Agradeço também à Professora Doutora Maria Lúcia Lepecki, cujos ensinamentos iluminaram sempre estas páginas, e à Professora Doutora Serafina Martins, pelo inestimável auxílio em caminhos difíceis da teoria da literatura.

Uma palavra especial de reconhecimento para o Professor Doutor Dylan Sailor, da University of California, Berkeley, pelo incentivo e por ter tido a generosidade de me ter feito chegar uma primeira versão do capítulo sobre Cremúcio Cordo, do seu livro Writing and Empire in Tacitus (entretanto publicado na Cambridge University Press).

Às funcionárias da Biblioteca da Faculdade de Letras devo um grato acolhimento; dirijo uma palavra especial para a Dr. ${ }^{a}$ Manuela Basílio, Graça Lopes, Eduarda Osório Lopes, Dr. ${ }^{a}$ Amália Cipriano, Ana Paula Alexandre, pois em muito contribuíram para facilitar as tarefas realizadas ao longo deste percurso.

Tenho ainda de agradecer à Ana Cristina Matafome, Ana Filipa Roldão, Ana Filipa Silva, Fernanda Carrilho e Lívia Barreto, pelo apoio, interesse e amizade. Ao J. Filipe, agradeço a inspiração.

${ }^{1}$ Outros problemas, como o apontado por Goodyear 197220 n.1, acerca de alguns acusativos do plural em is, quando o manuscrito testemunha es, não influenciam o trabalho de interpretação. 
Finalmente, estou grato à Professora Cristina Pimentel pela sábia e apaixonada orientaçáo, pelos diversos momentos de saudável discussão e amadurecimento de ideias, além de me ter fornecido inúmera bibliografia. À Professora agradeço ainda o Prefácio desta obra. 


\section{Prefácio}

Tem o leitor em mãos um estudo inédito sobre Tácito, o maior historiador da literatura latina. Tácito é um autor difícil. Cada palavra requer atenção, porque em cada uma se escondem sentidos que é preciso desvendar, porque cada uma é peça de um puzzle estilístico que não se deixa dominar à primeira leitura, porque exige do leitor a perspicácia de entender insinuaçóes, juízos de valor e tomadas de posição não explícitas mas sugeridas.

Tácito é um autor fascinante, por tudo o que acabámos de dizer e também pela fabulosa construção de um mundo em que a tirania impera e as personagens se movimentam, uns, muito poucos, em função de valores de que, orgulhosa e inabalavelmente, não abdicam, outros, a maioria, ao sabor do interesse imediato e mesquinho, que pode ser o de conservar a vida a qualquer preço ou, tão-só, a pequena promoção política ou social, o favor dos poderosos, ou a gloríola de um momento.

Por isso, a leitura de Tácito, para os que a empreendem com a consciência de que só um duro percurso os levará ao domínio da sua prosa tersa e elegante, revela-se uma extraordinária descoberta e, quase sempre, o começo de uma paixão de que é impossível libertarmo-nos: Tácito lê-se cada dia com mais deslumbramento, nunca entra no número dos autores que, uma vez lidos, já nos disseram tudo.

Ricardo Nobre, sendo tão jovem, deixou-se tomar por esse fascínio que Tácito exerce sobre nós. Mergulhou na sua obra, leu-a com o respeito e o escrúpulo que uma obra-prima requer, mas também com a ousadia da análise que desbrava caminhos novos de investigação e abre perspectivas originais que confirmam a riqueza da maior das obras do historiador, os Annales.

Num panorama tão pobre em que Tácito se afigura como um autor a quem raramente se dedicam, pelo menos entre nós, estudos ou investigação, já para não falar da escassez ou inexistência de boas traduçôes da sua obra, é sumamente de saudar que alguém, como Ricardo Nobre faz, tenha tido o arrojo de o tomar como autor de cabeceira, fazendo-nos partilhar as suas justas reflexôes sobre os Annales e revermo-nos, na desmontagem 
dos processos e das intrigas palacianas do tempo de Tibério, no que Tácito nos transmite sobre o lado mais negro da condição humana, mas também, por vezes, em clarão de glória e dignidade que o historiador não quer que fique esquecido, sobre o lado mais luminoso do ser humano, na sua fragilidade, na sua inteireza, na capacidade de viver a vida no meio das trevas e de enfrentar a morte como um porto seguro.

Professora Maria Cristina de Castro-Maia de Sousa Pimentel 


\section{INTRODUÇÃo}

Quando o jovem Libório, personagem principal do romance A Via Sinuosa, de Aquilino Ribeiro, adormece durante uma homilia e sonha que caminha no Paráso, ao encontrar-se com Deus, é assim recebido: "Olá, Libório, bem-vindo sejas! Então esse Tácito?” (Ribeiro 2008 51). O reconhecimento de Tácito enquanto representaçâo dos estudos de Latim, que ocupavam grande parte da educaçấo do devoto Libório, diz bem da sua importância para a cultura e formação individual. Por seu turno, Eça de Queirós admitia Afonso da Maia como entusiasta de Tácito, e encontramo-lo a ler o historiador no primeiro capítulo de Os Maias (Queirós s.d. 11 e 186). Não se pode dizer, porém, que a fama que estas referências da nossa literatura documentam tenha sido a mesma que o autor conheceu na Antiguidade - pois apenas Amiano Marcelino e, posteriormente, Sulpício Severo, Orósio, Sidónio Apolinar e Cassiodoro parecem ter sido influenciados por ele —, apesar de a Historia Augusta referir que o imperador Cláudio Tácito mandou copiar as obras e erigir estátuas em louvor de Cornélio Tácito, de quem reclamava parentesco (SHA Tac. 10.3). Na Idade Média este era um autor muito mal conhecido, e foi apenas no Renascimento (logo depois que se iniciou a ediçấo da sua obra) que começou a ser apreciado e a servir de fonte de inspiração a outros escritores.

Com efeito, da vida daquele que é considerado o maior historiador romano pouco se sabe (Birley 2000). As incertezas acerca da sua biografia começam pelo nome. O códice Mediceus I (o mais antigo, que data do século IX e transmite os Annales do início ao fim do livro VI) identifica-o como Publius Cornelius Tacitus, mas o códice mais recente (Mediceus alter, do século XI) e Sidónio Apolinar (Epistulae, 4.14.1 e 4.22.2) nomeiam-no Gaius. Contudo, as informaçóes seguras que existem sobre a vida de Cornélio Tácito sáo recolhidas das suas obras, de algumas cartas de Plínio-o-Moço (de quem era, aliás, muito amigo'), e de algumas evidências arqueológicas.

${ }^{1}$ Os dois foram herdeiros de L. Dasumico de Córdova (CIL vi 10229). É famoso o episódio narrado por Plínio, em que, durante uns jogos, Tácito estava a falar sobre assuntos eruditos com um cavaleiro, que lhe pergunta: Italicus es an prouincialis?, ao que Tácito lhe responde Nosti me, et quidem ex studiis. E o cavaleiro pergunta Tacitus es an Plinius? (Plin. Ep. 9.23.2-3). Comprova-se que o historiador era um entendido em várias matérias, um 
A data do nascimento, c.55-58 d.C., é deduzida pelas datas em que chega às magistraturas; o seu local de nascimento também é uma incerteza, mas, pela predilecção que demonstra por certas regióes, talvez seja a Itália Transpadana ou as Gálias (Gordon 1936). O seu pai terá sido um cavaleiro, procurador da Gália Bélgica, de que fala Plínio-o-Velho (Nat. 7.76). A sua formação em oratória (Dial. 1.1-2, 2.1) permitiu-lhe auferir grande prestígio como advogado e orador ${ }^{2}$, além de lhe dar matéria para escrever o Dialogus de Oratoribus (que data possivelmente de 102), onde se discorre sobre as causas da decadência da oratória.

É durante o principado de Vespasiano que entra na vida pública, encontrando-se em Roma a partir de 75, provavelmente a preparar a carreira senatorial e a ouvir discursos públicos (Dial. 2.1). Por volta de 76-77, casa com a filha de Gneu Júlio Agrícola, de quem escreve a biografia (De Vita Iulii Agricolae, em 98). Quando o sogro morre (23 de Agosto de 93; $A g$. 45.5), Tácito encontra-se fora de Roma, tendo regressado de imediato, para aí permanecer durante os últimos anos do principado de Domiciano (Ag. 2-3, 45). Aquela ausência explica-se pelo facto de ter estado em serviço público numa província (provavelmente como legatus pro praetore), depois de ter feito parte do colégio dos quindecimuiri sacris faciundis, em 88 (ano em que promove os jogos seculares; Ann. 11.11.1). Em 97, é cônsul suffectus e pronuncia a oração fúnebre de Vergínio Rufo, vencedor de Víndice (Plin. Ep. 2.1.6). Por volta de 99-100, processa o ex-governador da Africa, Mário Prisco, por extorsão. De 102 a 104, talvez tenha governado uma província imperial e, c.112-113, foi procônsul da Asia, cargo de prestígio em que atinge o topo da carreira senatorial (Dittenberger 1960 487).

Depois de Germania (De Origine et Situ Germanorum, de 98?), escreveu as Historiae em 12 ou 14 livros, obra na qual usa o esquema analístico para narrar as guerras civis de 69, os principados de Vespasiano, Tito e Domiciano. Trabalhou nela até 108-109 (Plin. Ep. 6.16, 6.20, 7.20, 7.33.1, 8.7), restando actualmente apenas

estudioso reconhecido, e até que teria sotaque diferente do romano. O mesmo Plínio sugere que Tácito também caçava. De facto, Plínio sabe que o amigo iria rir com uma graça que este lhe conta, a propósito da sua produção intelectual durante uma caçada, aconselhando-o a que também ele leve material de escrita para o bosque e aproveite o silêncio da natureza (Ep. 1.6).

${ }^{2}$ Plínio chama-lhe laudator eloquentissimus (Ep. 2.1.6) e diz que ele fala eloquentissime et, quod eximium orationi eius inest, $\sigma \varepsilon \mu \nu \tilde{\omega} \varsigma$ (2.11.17); cf. Plin. Ep. 4.13.10. 
os quatro primeiros livros e o início do quinto (perdeu-se a parte respeitante a Domiciano e a maior parte relativa a Tito).

Os Annales (ou Ab excessu diui Augusti, que retoma o título da obra de Tito Lívio) são a sua obra-prima. Perfazendo um total de 16 ou 18 livros $^{3}$, contam a história de Roma desde a morte do imperador Augusto até Nero. O livro V perdeu-se no Mediceus I e o Mediceus alter começa no livro XI, pelo que também não temos uma porção significativa que incluía o principado de Calígula e o início do de Cláudio (livros VII-início do XI). Também o final da obra se perdeu. Actualmente, termina na morte de Trásea Peto (16.35), mas presume-se que o seu fim fosse a narração da morte de Nero.

Empregando, como o nome indica, o esquema analístico, próprio das primeiras manifestaçóes da historiografia em Roma, Tácito terá redigido os Annales pelo menos até 116, dedução que assenta na referência à campanha dos Partos e aos limites do império em 2.61.2. É possível que, pela morte do autor, a obra tenha ficado inacabada, teoria confirmada por uma alegada falta de revisão final, tais as diferenças de estilo entre a primeira parte e a segunda (cf. Adams 1972).

Sobre o estilo e interesse literário da obra de Tácito, existem muitos estudos, referidos na bibliografia ${ }^{4}$, mas não será de mais referir algumas das características reconhecidas no seu modo de escrever, a que este trabalho também presta atenção. Recorde-se, como introdução, esta citação de Burnouf 1861 xi-xii:

ce que tout lecteur doit admirer dans Tacite, c'est ce style tantôt vif et rapide, tantôt calme et majestueux, souvent sublime, toujours simple dans sa grandeur, et toujours original et vrai, parce qu'il part d'une âme fortement convaincue et d'un esprit qui pense d'après lui-même; c'est cette précision, qui consiste à dire ce qu'il faut, rien de plus, rien de moins, et qui n'exclut ni la pompe des expressions, ni l'éclat des images, ni l'harmonie des périodes. La concision même, qu'on reproche quelquefois à Tacite, et qui, avare de paroles, enferme dans ses coupes heurtées et ses oppositions inattendues plus de sens que de mots, n'est ordinairement qu'une heureuse hardiesse, un secret du génie, qui conçoit fortement

${ }^{3}$ Sabe-se que as Historiae e os Annales completariam um total de 30 livros.

${ }^{4}$ Em Furneaux 1896 38-74 são compulsados os traços gerais do estilo dos Annales, podendo encontrar-se aí exemplos de todas as características que a seguir se enunciam; v. ainda Perret 1954 e Oakley 2009. 
sa pensée et la dessine à grands traits. Voilà ce qui caractérise la diction de Tacite; voilà pourquoi on ne peut la comparer avec celle d'aucun autre écrivain, pas même de Salluste, qui, avec autant de nerf et de justesse, a peut-être moins âme et de véritable chaleur.

Estas características manifestam-se em estratégias discursivas próprias, de que decorre a fusão dos géneros (historiográfico, poético, oratório) e dos modos (lírico e narrativo ${ }^{5}$ ). Assim, o estilo de Tácito caracteriza-se, por um lado, pelo gosto pela novidade (recuperando arcaísmos, traduzindo literalmente expressóes gregas, criando morfológica e sintacticamente novas formas, termos, sentidos) e, por outro, pela contínua busca de variedade (uariatio). De facto, ao mesmo tempo em que conserva construçóes paralelísticas (como a anáfora, simetria, agrupamentos binários ou ternários, isocólon e homeoteleuto), verifica-se um esforço para evitar repetiçóes (empregando sinónimos, desfazendo a simetria de termos, casos, preposiçóes, tempos e modos verbais). Os anacolutos e as alternâncias entre frases longas e curtas variam as estruturas sintácticas, enquanto o tipo de ligação entre oraçóes faz com que os enunciados ganhem cor e significado pela sua justaposição.

$\mathrm{O}$ estilo de Tácito caracteriza-se ainda pela abundância de imagens vivas, violentas, sombrias e nebulosas como os pensamentos, metáforas (algumas emprestadas de verbos de acção e de movimento), personificação da natureza e de entidades inanimadas, objectos e abstracçóes. A ordem das palavras está, muitas vezes, ligada à musicalidade que os sons das palavras conferem à narrativa.

A concisão é outra grande propriedade do latim de Tácito, pois dela decorre o vigor da sua escrita. É certo que se conservam (principalmente nos discursos) o pleonasmo, a hendíadis e a amplificação oratória, mas são o assíndeto, a elipse, o zeugma, a substituição de oraçóes principais ou relativas por construçóes mais curtas, apostas, e o particípio e ablativo absoluto que são mais recorrentes e importantes. A brevidade resulta, porém, no obscurecimento do discurso, mas a eliminação de palavras inúteis realça o sentido das que estão expressas. De facto, Tácito usa táo poucas palavras quanto possível e agrupa-as com significado semanticamente marcado. Aliás, o sentido próprio dos vocábulos é tomado do contexto.

${ }^{5}$ A título de exemplo, refira-se que há inúmeros ecos de Virgílio e de Horácio. A intenção é enfatizar um enunciado ou dar proeminência a uma palavra. 
Com efeito, os vocábulos são escolhidos com rigor: na prosa de Tácito lêem-se os termos apropriados, expressivos com intensidade (por exemplo, a hipérbole traduz a indignação que sente perante os acontecimentos que narra). E a atitude pedagógico-didáctica é plasmada em sententiae, que surgem sobretudo no fim de um desenvolvimento: "Son expression est aussi pleine que sa pensée"6. Estes enunciados epigramáticos são, de acordo com Miller 1992 10-18, fonte de uma profunda e muitas vezes trágica experiência de vida; são elegantes e retoricamente elaborados, mas têm alguma coisa de importância para dizer — algo que pode ser amargo ou cínico, mas nunca artificial ou afectado.

O estilo do autor espelha, assim, a concepção que Tácito tem de História, cuja função é revelar a psicologia do ser humano tendo em vista a identificação dos bons e maus exemplos. Esta perspectiva justifica o desinteresse do autor por descriçóes realistas de corpos e expressóes. $\mathrm{Na}$ verdade, a ele se adequa a afirmação de Axel Münthe 2001 269: "Para aqueles a quem a psicologia interessa, um retrato corrente dum rosto humano tem um valor mínimo.”

Ao fazer uso destes recursos, Tácito não pretende entreter o leitor, senão surpreendê-lo, chamando a sua atenção para o ponto de vista expresso. Nas suas frases sinuosas pode ser vista não só a busca de variedade, mas a intensidade e a amargura dos seus pensamentos. Concluindo, pode dizer-se, tal como Wuilleumier $1978 a$ 1, que "Tacite domine toute la littérature latine. Par sa sensibilité d'homme, sa loyauté d'historien, sa clairvoyance de moraliste, sa pénétration de psychologue et son talent d'artiste, malgré les lacunes de l'information, les excès du pessimisme et les abus de la rhétorique, il s'inscrit parmi les plus nobles figures et les plus riches écrivains de l'humanité."

Apesar de o novo regime político romano se basear numa sucessáo por hereditariedade (na medida em que Augusto adopta aqueles que reúnem capacidades para assegurar o poder), na obra Ab excessu diui Augusti, Tácito mostra, explícita ou implicitamente, que, no Principado, o poder não é alcançado por testamento sem que haja influências alheias. São intrigas políticas, urdidas com fins imediatos diversos, como a retirada coerciva da cena política dos agentes que poderiam ser oposição à assunção de poderes

${ }^{6}$ Wuilleumier $1978 a$ l. Cf. últimas frases dos capítulos 6, 8, 55, 69, 73 e 81, do livro I. 
"ilegítimos" (onde se incluem falsas acusaçôes, em que têm especial relevo as acusaçóes de maiestas) ou relações amorosas que configuram traição conjugal. Mesmo que a intriga apareça nos Annales enquadrada em diferentes moldes, o seu objectivo último é normalmente um: a obtenção ou manutenção do poder.

Os Annales são reflexo de uma sociedade cujo modelo político tinha sofrido uma enorme mudança e que procurava ainda adaptar-se ao novo regime, dominado por príncipes que chegam ao poder como resultado de operaçóes de bastidores. A simulação é a característica mais visível, pois é com uma aparência enganosa que as personagens actuam, num regime que é ele mesmo de cosmética. M. Comber 1997 52, que realça o lado intriguista da historiografia imperial, reconhece a vertente especulativa da versão da História desse tempo: "Much imperial history (...) took place behind closed doors and was shrouded in mystery. Hard facts were difficult to come by. There was, therefore, considerable scope for speculation and dramatic recreation". Partindo deste pressuposto, e com a consciência de que a escrita histórica não é alheia às categorias da narrativa literária, o objectivo deste estudo é a análise das intrigas e traiçôes, tendo em vista a identificação de processos retóricos dominantes, no enquadramento narrativo-descritivo e no estilo do autor.

$\mathrm{O}$ estudo encontra-se dividido em três capítulos. $\mathrm{O}$ primeiro, mais curto, tem um forte componente teórico. Nele, analiso as semelhanças formais entre a escrita historiográfica e a literatura que, na legitimação retórica, conhecem diversas sobreposiçôes. Trata-se de um capítulo em que se demonstram igualmente as ténues fronteiras entre a criação literária e a História, nomeadamente a sua relação com a Verdade. Esta ideia vem reforçada por alguns apontamentos sobre o papel da historiografia na antiguidade. Meio de promoção política e de elevação nacionalista, a História era vista como um género literário que não só tinha algo a ensinar, mas sobretudo tinha de o fazer de forma lúdica e retoricamente elaborada. Por isso, é importante atentar no testemunho do historiador, autor dos Annales. Pondo em relevo os momentos da narrativa em que a voz diegética se assume como protagonista, dou a conhecer o 'plano do historiador', não só em passos em que se verifica uma posição doutrinária relativa à historiografia, mas também no uso e fidelidade de Tácito relativamente às suas fontes.

Os capítulos 2..$^{\circ}$ e $3 .^{\circ}$ inserem-se noutro âmbito. Ainda que neles inclua alguns preceitos da teoria literária, eles debruçam-se 
essencialmente sobre o texto dos Annales e analisam-no na prática. O 2. ${ }^{\circ}$ capítulo trata os passos mais significativos em que se verifica a actuação insidiosa de algumas personagens. O pouco que Tácito escreveu sobre o principado de Augusto permite estabelecer um modelo retórico que se espelha noutros passos, não só pelo vocabulário e construçóes empregues, mas sobretudo pelos motivos ambíguos que levam à perpetração de tais actos. Também é analisada a eliminação da descendência de Augusto, a fim de colocar Tibério no poder. Quando este o assume, Germânico surge como uma das personagens com mais preponderância na narrativa, pelas acçóes que empreende e pelo que representa para outras personagens, principalmente para o povo. O seu papel no enredo da história, as isotopias a si ligadas, a sua relaçáo com Tibério e Pisáo, bem como a sua morte serão objecto de pormenorizada análise. Morto Germânico, Pisão, o seu alegado assassino, é julgado e acaba por se suicidar ainda no decorrer do processo: estudam-se esses passos, juntamente com os que dão conta da absolvição vergonhosa de Plancina, a sua esposa. Assim, apresento um estudo retórico de alguns episódios que considero mais relevantes em que Augusto, Tibério, ou Lívia Augusta surgem como (possíveis) responsáveis por crimes, mediante intrigas ocultamente orquestradas.

Finalmente, no $3 .^{\circ}$ capítulo, estudam-se principalmente episódios representativos que configuram, pela actuação do poderoso ministro de Tibério, Sejano, e seus sequazes, exemplos de intrigas palacianas: a sedução de Lívia Júlia, que aquele torna cúmplice da morte de Druso, filho de Tibério; a perseguição de amigos de Germânico com o intuito de melindrar Agripina e os filhos (estuda-se o caso de Tício Sabino pelo desenvolvimento que conhece na obra, mas o de Gaio Sílio e Sósia Gala são também significativos); a tentativa de eliminação da casa de Germânico ${ }^{7}$. Como exemplo da influência dos clientes de Sejano, apresenta-se o caso da perseguição de Cremúcio Cordo, que denuncia um ataque à liberdade de expressão que caracterizava a evolução do regime imperial. O capítulo inicia-se, porém, com o estudo do episódio da acusação de maiestas lançada sobre Libão Druso, sem que Sejano seja agente provocador da mesma. No entanto, por ter sido o primeiro caso deste género, o narrador dá-lhe especial

${ }^{7}$ O estudo do plano do ataque a Agripina e aos filhos de Germânico é dificultado pelo facto de se ter perdido a porção de texto relativa à morte de Nero, o primogénito, e ao exílio de Agripina, no livro V. 
importância e na sua análise poderão reconhecer-se vários elementos que o aproximam dos sequentes.

Pode, assim, verificar-se que este trabalho incide sobretudo sobre os quatro primeiros livros dos Annales, focando primeiro as intrigas antes de Sejano, e em seguida as orquestradas depois que a sua influência começa a fazer sentir-se. É natural que assim aconteça, tendo em consideração a perda do livro $\mathrm{V}$, e atentando no facto de o livro VI se debruçar já sobre crimes perpetrados não por meio de intrigas ${ }^{8}$, mas como resposta à cumplicidade e amizade de Sejano, num primeiro momento, e, depois, sob a sinistra actuação de Macrão. Por outro lado, tratam-se apenas casos ocorridos na corte imperial ou que envolvem o poder em Roma, deixando-se de lado episódios relativos ao poder nas províncias (nomeadamente no que à Arménia e à Pártia diz respeito).

Como se vê, o estudo que agora se apresenta não tem como objectivo verificar no âmbito da História e da epistemologia a veracidade da narrativa, mas somente o estudo retórico do texto tacitiano. Também por isso, mas sobretudo porque já não existem muitas das fontes em que o autor se baseou para escrever a sua obra, neste trabalho não se enveredou pela confrontação com versóes de outros historiadores. De facto, se autores como Suetónio e Díon Cássio escreveram a história do principado de Tibério, também é verdade que são escritores posteriores (ou, no limite, contemporâneos, no caso de Suetónio) e que o seu estilo e linguagem são muito diferentes ${ }^{9}$.

${ }^{8}$ Para a natureza das acusaçóes de maiestas no livro VI, v. Walker 1952 105-108. Neste livro dos Annales, verifica-se a fraca presença de vocabulário indicador de intrigas — dolus, fraus, insidiae, ambitus surgem no livro VI referentes, e.g., a fraus financeira (6.16.2) ou relativa à Astrologia (6.21.1), e mais significativamente no episódio da deposição de Artabano do trono dos Partos, e sequente recuperaçáo do poder por parte deste (6.31-33, 6.3637) - e de ocultaçáo (occultus, obscurus). A isotopia aparência-realidade não se manifesta com a proeminência de outros livros: apenas 6.6, 6.39.2 e 6.51 são significativos desse tema, se se atender àquilo a que Walker 1952 49 identifica como "the practice of inferring motives which make an action appear hypocritical or at least give it a meaning unlike the obvious one."

9 Isto não quer dizer, naturalmente, que não se apresentem, em casos pontuais, a versão consagrada pela História (mediante outras fontes e o uso da arqueologia). 
Capítulo I

A ConstruÇÃo e as Fronteiras da Instituição Literária:

Tácito, Literatura e História 
Esta reflexão inicial sobre a natureza literária de um texto pretende legitimar o discurso histórico como artefacto literário (White 1978), a fim de se proceder à sua análise retórica. Com efeito, o que se verifica a propósito da elaboraçáo estética de um enunciado literário tem de ser dito do discurso da História, nomeadamente se se estiver a falar de uma historiografia como a que se praticava na Antiguidade, onde se encontram vários testemunhos da elaboração da História com fins retóricos e lúdicos.

De facto, a atitude institucionalizada em relação à História tem vindo a evoluir desde Heródoto, mas há um elemento programático universalmente comum a todas as épocas: a História é o relato da verdade (alêtheia) e é nesse facto que se pode contrapor ao mythos da literatura. Se as primeiras manifestaçóes de prosa narrativa são do género historiográfico (Kennedy 1989 184), a concepção de História na Antiguidade tem, ainda assim, características que a isolam da concepção moderna, que está por seu turno contaminada pelos preceitos positivistas e pela tentativa de independência desta área do saber relativamente aos estudos literários. A distância temporal e a evolução do conceito daí resultante levam a que A. J. Woodman 199818 afirme que "ancient and modern historiography are two quite different things", pois que se esperam coisas diferentes de cada uma delas. Por isso, quaisquer que sejam as conclusôes relativas ao papel dos estudos literários no domínio da historiografia, tem de se aceitar que, na Antiguidade, a escrita da História era um exercício eminentemente estético e literário ${ }^{1}$.

${ }^{1}$ Leeman 1963 329-363 fornece uma perspectiva alargada sobre o modo como a Antiguidade entendia a História, bem como a sua relação com a Retórica. 


\section{História e Literatura}

No século XIX, os pensadores positivistas continuaram um processo iniciado no Século das Luzes de institucionalização da História como ciência autónoma ${ }^{2}$, reclamando-a para o âmbito da epistemologia e resgatando-a da área da Retórica, onde ocupara um importante lugar. É porém larga a discussão académica acerca do conceito de História, sua prática e metodologias, e, mais significativamente, acerca da forma como ela é escrita. A tentativa de isolamento e de afastamento da produção estética e artisticamente elaborada (que caracteriza a escrita literária e que parecia contaminar a da História) tem vindo a ser posta em causa por diversos historiadores, ao mesmo tempo que outros repudiam essa aproximação. Defende G. R. Elton que, para os historiadores, "lutar contra as pessoas que submeteriam os estudos históricos aos ditames da crítica literária equivale a, de certa maneira, lutar pela nossa própria sobrevivência" ${ }^{3}$.

Autores como Paul Veyne ${ }^{4}$, Hayden Whites, E. H. Carr (1986), Lionel Gossman (1978), ou Louis O. Mink (1978) têm outra perspectiva. Declaram estes críticos literários e historiadores que a História tem, na sua redacçáo e exposição, uma vertente literária, quer em termos linguísticos ("literariedade"), quer em termos de ficcionalidade. Por isso, o objectivo de historiadores e de romancistas é semelhante. Afirma H. White 197621 que "the extent to which the discourse of the historian and that of the writer of imaginative fictions overlap, resemble, or correspond with each other", uma vez que "the forms of their respective discourses and their aims in writing are often the same". Concomitantemente, "the techniques or strategies that they use in the composition of their discourses can be shown to be substantially the same,

${ }^{2}$ V. Schaff 1988 85-116; Neff 1961 189-202.

${ }^{3}$ Elton 1991 49, citado por Evans 2000 20. No entanto, como se verá, a relação entre História e literatura opera-se, antes de mais, do ponto de vista do processo de escrita, narrativo, e não do ponto de vista epistemológico.

${ }^{4}$ Autor que esbate a distinção entre as duas formas de escrita, nomeadamente em Veyne 1971.

5 White 1987 41-62; White 1976; White 1985; cf. Munslow 2000 s.v. "White, Hayden". 
however different they may appear on a purely surface, or dictional, level of their texts".

Esta sobreposição explica-se porque quer historiadores, quer romancistas "wish to provide a verbal image of 'reality'. The novelist may present his notion of this reality indirectly, (...) by figurative techniques, rather than directly, (...) by registering a series of propositions which are supposed to correspond point by point to some extra-textual domain of occurrence or happening, as the historian claims to do." Nesta medida, é legítimo afirmar-se que "history is no less a form of fiction than the novel is a form of historical representation" (White 197622 e 23).

Mesmo ao defender-se que a História tem de mostrar os factos passados, apoiada em fontes (documentais escritas ou arqueológicas, por exemplo), não se pode admitir a existência de uma concepção expositiva da História: enunciar um facto ocorrido numa determinada data e em certo local não é História. Esta exige a criação de um sistema de selecção, organização e arranjo de informação e uma arquitectura narrativa que a transmita. G. M. Trevelyan chegou a afirmar que a História "era uma fusão de elementos científicos (pesquisa), fantasiosos ou especulativos (interpretação) e literários (apresentação)", observando também que, "no que respeita à ocorrência dos acontecimentos, a recolha de factos e a avaliação dos testemunhos são, sob certos aspectos, científicas; contudo, tal não se aplica à descoberta das causas e dos efeitos inerentes aos mesmos acontecimentos"6.

Por seu lado, se o termo "literatura" tem vindo a ser entendido como confinado à identificaçáo de obras de valor estético reconhecido ${ }^{7}$, não se pode deixar de notar um pendor narrativo na actividade de escrita da História, "em cujo contexto é possível encontrar projectadas técnicas narrativas consagradas pelo romance (caracterização das personagens, retrospectivas, etc.)", como diz Carlos Reis 1997118.

Entendo, juntamente com os críticos citados, que não só a escrita da História pode ser literatura, na medida em que as qualidades da escrita daquela se misturam com as do texto literário, mas também que a literatura pode incluir no seu âmbito a historiografia. A diferença baseada no referente real e empírico das acçóes narradas, ou seja, no campo epistemológico, é atenuada

\footnotetext{
${ }^{6}$ As citaçóes de G. Trevelyan são de Evans 200039.

7 Para a "definição" de literatura, v., e.g., Silva 1987 1-42.
} 
pelo aparecimento dos romances históricos ${ }^{8}$, ao mesmo tempo que o Romantismo e o Realismo e Naturalismo trouxeram ainda textos ficcionais baseados em verdades alegadas?.

Carlos Reis observa: "a interacção literatura/História formula-se de modo explícito. Referimo-nos aqui, naturalmente, àquelas obras em que se concretiza a incorporação de temas históricos; é o que acontece com a epopeia, com o romance histórico e com o drama histórico. Essa incorporação não esgota, contudo, as possibilidades de representação literária da História, observável também em obras literárias de diferentes tempos históricos”. O autor dá como exemplo Os Maias, obra que "centra o fundamental da sua acçáo no devir de uma intriga (...) e na ilustraçáo de 'episódios da vida romântica', sem que isso iniba o privilégio de "aspectos importantes da História de Portugal; a emergência do vintismo, as lutas liberais, os exílios que elas suscitaram, a Regeneração, constituem componentes importantes do cenário do romance, lembrando possíveis conexôes existentes entre ele e o Portugal Contemporâneo de Oliveira Martins. Ora o que torna Os Maias uma obra a todos os títulos fascinante é o diálogo entre a História e a ficção" (Reis 1997 87-88).

Há que lembrar que "essa representação não obedece aos protocolos de comportamento do historiador propriamente dito. Não está em causa, portanto, nem n'Os Maias nem em nenhuma outra obra literária, a reconstituição fiel de personalidades e cenários históricos, mas antes a articulação de elementos ficcionais com essas personalidades e cenários históricos, no contexto de uma interacção História/ficção quase sempre muito complexa" ${ }^{10}$.

${ }^{8}$ Para os quais os romancistas fazem trabalho de investigação heurística e hermenêutica semelhante ao de um historiador: cf. J. Saramago, "História e Ficção", citado por Reis 1997 500-503. Um estudo do romance histórico português, com uma breve introdução teórica, é fornecido por Marinho 2005.

9 Camilo Castelo Branco é um exemplo flagrante desta técnica de incorporação da realidade nas suas obras. Por exemplo, Amor de Perdição baseia-se em "livros de antigos assentamentos das cadeias de Relação do Porto" - e mesmo se a história de Simão Botelho fosse verídica, a construção do discurso narrativo é ficcional. Outro exemplo do mesmo autor é o texto de A Sereia, um relato "verídico" que também se baseia num documento "autêntico". Para a discussão deste elemento, v. Martins 2005.

${ }^{10}$ Reis 1997 88. De notar ainda que, em obras literárias de carácter histórico, representam-se, "num contexto ficcional, figuras, eventos e lugares cujas propriedades fundamentais o escritor respeita, como forma de assegurar o seu reconhecimento enquanto entidades históricas”. Sobre a diferença da 
Numa outra perspectiva, a literariedade (literaturnost) também se pode aplicar à escrita histórica. Esta literaturnost é uma noção desenvolvida por Roman Jakobson (1973 15) no contexto do formalismo russo, que postula que a "linguagem literária tinha de se distanciar dos estereótipos, dos lugares-comuns, da linguagem desgastada pelo uso quotidiano; daí a atenção dada aos processos capazes de provocarem a sensaçáo de estranhamento", como resume Matos 2001 246. Esta distinçáo entre os registos de linguagem surge já em Aristóteles ${ }^{11}$ :

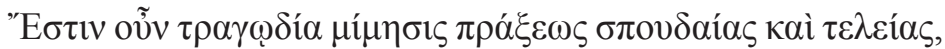

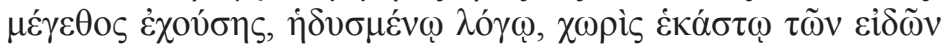

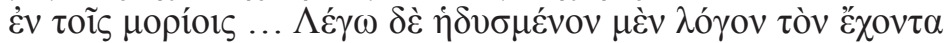


De facto, lembra ainda Carlos Reis: "A escrita literária pode ser entendida como prática dotada de um certo índice de especificidade técnica, empreendida por um sujeito que a leva a cabo num contexto cultural a que dificilmente é indiferente e assumindo uma atitude diversa da de outros sujeitos quando enunciam outras linguagens". Posto isto, poderá concluir-se que "escrever literatura é (...) um acto deliberadamente estético" (Reis 1997105 e 103, respectivamente). A literariedade de um texto é, pois, colocada ao serviço da estética, elemento considerado fundamental para entender qualquer texto literário (Waugh 2006).

profundidade da construção de personagens na História e na literatura, v. Cap. 2, sec. 3 .

${ }^{11}$ A diferenciação feita por Jakobson entre a linguagem não-marcada (do dia-a-dia) e a linguagem marcada (literária) tem por isso antecedentes antigos.

${ }^{12}$ Poética, 1449b: 'tragédia é a imitação de uma acção elevada e completa, dotada de extensão, numa linguagem embelezada por formas diferentes em cada uma das suas partes (...). Por linguagem embelezada entendo a que tem ritmo, harmonia e canto'. As traduçôes do grego são de Valente 2007. Há uma linguagem para cada momento da tragédia, assim como o resultado final tem de ser distinto da produção linguística do dia-a-dia. Este registo da linguagem

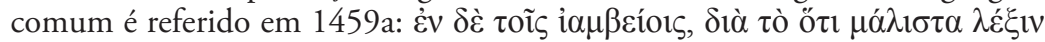

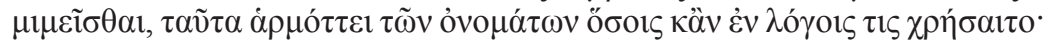

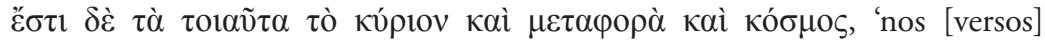
iâmbicos, porque se imita o mais possível a linguagem corrente, convêm as palavras que se usariam na língua falada. São elas a palavra corrente, a metáfora e o ornamento.' 
No entanto, a "função estética" da linguagem defendida por Jakobson tem sido posta em causa pelos Estudos Literários do século XX (Silva 1987 45-79), não sendo, assim, "possível uma definição de literatura com base na caracterização da linguagem literária”, como nota Matos 2001 253. Esta postulação é verificada ainda que as marcas linguísticas que caracterizam a linguagem literária tenham vindo a ser identificadas ou definidas pelos formalistas ("estranhamento"), estruturalistas ("desautomatização") ou pelo new criticism ("ambiguidade") ${ }^{13}$. Carlos Reis 1997 117-118 defende:

o discurso literário náo reclama uma especificidade expressiva que o autonomize claramente em relação às utilizaçóes não artísticas da linguagem verbal. E se algumas propriedades formais parecem poder responsabilizar-se por essa especificidade (o verso, a rima, a conotação, etc.), deve acrescentar-se que tais propriedades ocorrem também em discursos não literários, continuando a ser, por si sós, insuficientes para a determinaçẫo formal da literariedade.

O desvio da norma é, em termos linguísticos, algo inexistente pelo simples facto de, no limite, não haver norma, mas também não haver linguagem que não seja, ontologicamente falando, desvio, metáfora, idiossincrasia. Aguiar e Silva salienta que em períodos como o Barroco, o Simbolismo, o Decadentismo e movimentos de vanguarda "há a tentativa de a literatura descolar do 'normal' tendo em vista uma ornamentação e enriquecimento" que náo se vêem, por exemplo, em correntes como o Romantismo e principalmente o Realismo, onde se verifica, pelo contrário, um "esforço de reduzir, ou eliminar, a distância comunicativa em relação a um público leitor cada vez mais extenso" ou então "com o objectivo de apreender mais directa, fiel e transparentemente a realidade do mundo físico e social" (Silva 1987 165-166).

Esta proximidade legitima que, ao longo da História, muitos tenham sido os textos que foram sendo transpostos para o campo do literário, situação que remete para a problemática das fronteiras do campo literário e do cânone (Waugh 2006). Se, por

${ }^{13}$ Roland Barthes sublinha a natureza mimética de todo o discurso, algo que impossibilita um discurso náo marcado, ideia secundada por White 1976 23: "all written discourse is cognitive in its aims and mimetic in its means. And this is true even of the most ludic and seemingly expressivist discourse, of poetry no less than of prose, and even of those forms of poetry which seem to wish to illuminate only 'writing' itself". 
exemplo, do cânone literário português fazem parte obras como a História de Portugal, de Alexandre Herculano, ou as Crónicas, de Fernão Lopes, é porque "associamos essa elaboração a uma atitude literária, até ao ponto de podermos ser induzidos a operar a transferência institucional de textos em princípio não literários para o campo do literário" (Reis 199772 e 124). Sáo autores que recorrem, "nos seus textos, a procedimentos técnico-estilísticos de ressonância literária" ${ }^{14}$.

Ainda a este propósito, devem recordar-se duas cartas que Eça de Queirós dirigiu ao amigo Oliveira Martins. Estas documentam a posição do escritor sobre a contaminação da literatura na História: "Recreaste' homens - belo esforço! O teu D. Pedro, o teu D. Duarte são 'criaçóes' superiores. Eram assim? Se eram, bendita seja a tua arte de ressuscitador! Se não eram, honra à alma nobre que pôde inventar almas." 15 Igualmente célebres são as críticas apontadas ao livro $A$ Vida de Nun'Álvares: "não me agradam muito certas minudências do detalhe plástico, como a notaçáo dos gestos, etc. Como os sabes tu? Que documentos tens para dizer que a Rainha, num certo momento, cobriu de beijos o Andeiro, ou que o Mestre passou pensativamente a mão pela face? Estavas lá? Viste?"16

${ }^{14}$ Reis 199721 recorda que o contrário é possível e legítimo: "não raro, as obras literárias revestem-se de um certo significado histórico-cultural, em conexão directa com a sua capacidade de dialogarem com a História, com a Sociedade e com a Cultura que as envolvem e que enviesadamente as motivam".

${ }^{15}$ Carta de 23 de Julho de 1891, sobre Os Filhos de D. João I, in Castilho 1983165.

${ }^{16}$ Carta de 26 de Abril de 1894: Castilho 1983314. 


\section{Historiografia Antiga}

Se historia, em latim, significa 'narrativa de eventos, conto, fábula, história', a origem grega da palavra revela um carácter eminentemente epistemológico, do campo do saber por se ter assistido ao vivo ${ }^{17}$. Pode pensar-se que toda a informação utilizada para a construçáo de um entrecho historiográfico é originada pelo testemunho in loco da acção ou fenómeno descrito, ainda que essa informação directa nem sempre seja possível. Dessa forma, entra-se numa sucessão de fontes que se baseiam noutras fontes e que alteram, mais ou menos significativamente, a informação de raiz. A alteração que essa informação recebe é resultado de um tratamento essencialmente retórico onde também flui a imaginação. Tal tratamento é comprovado quando se pode confrontar o texto com a fonte: os acrescentos, as omissóes e as alteraçôes de estilo são permitidos ao historiador tal como são ao criador literário ${ }^{18}$.

O processo de modificação estilística de um texto-base é explorado e descrito com rigor por A. J. Woodman ${ }^{19}$, que sustenta que os historiadores romanos "were hardly great travellers, doing on-the-spot research into the distant places they described in their works" (Woodman 1998 10), recorrendo então à imaginaçáo ou à experiência pictórica fornecida pela Retórica, a fim de colorir e complexificar a sua narrativa ${ }^{20}$. Tem particular relevo, nesse domínio, a descrição de paisagens e de grandes batalhas ${ }^{21}$.

Esta estratégia discursiva, ainda segundo o mesmo autor, explica que determinados episódios se "repitam" em momentos

${ }^{17}$ O vocábulo historia relaciona-se com o verbo oida: Chantraine 1999 s.v. oí $\delta$.

${ }^{18}$ Pode aduzir-se novamente o exemplo de Camilo Castelo Branco, em $A$ Sereia.

${ }^{19}$ Woodman 1998 1-20. Sobre o papel dos estudos deste ensaísta no campo da crítica da historiografia antiga, v. Feldherr 20097.

${ }^{20}$ Woodman 1998 7-18 exemplifica com descriçóes de Tito Lívio e, mais significativamente, de Quinto Cúrcio Rufo, que descreve paisagens com vegetaçóes que nunca existiram nesses locais. $\mathrm{O}$ historiador respondia, assim, ao gosto do público pelo exótico mais do que ao rigor científico.

${ }^{21}$ Sabe-se que a ekphrasis era um dos progymnasmata que formavam os oradores na Antiguidade: Kennedy 2003 45-47, 86, 117-120, 166-168 e 218-221; Pernot 2005148. 
históricos diferentes ${ }^{22}$ : as "coincidências" ou são invençôes ou derivações da verdade. A criação do ambiente onde ocorrem e a adaptação de acçóes reais mais não fazem do que tentar responder ao gosto e sensibilidade dos leitores.

A Rhetorica ad Herennium ensina que, se os ouvintes começarem a ficar cansados (defessi) do discurso, o orador deve dizer algo que provoque o riso (risum mouere). Uma maneira de o fazer é usar a historia, que neste contexto é entendida como uma curiosidade histórica com graça (Rhet. Her. 1.6.10). Também Quintiliano aponta as características retóricas da História: uerbis remotioribus et liberioribus figuris narrandi taedium euitat. No mesmo contexto, a História é sucintamente definida por aproximação à poesia: est enim [historia] proxima poetis et quodammodo carmen solutum, et scribitur ad narrandum non ad probandum (Inst. 10.1.31). A aproximação da História à poesia ${ }^{23}$ havia sido feita já por Aristóteles:

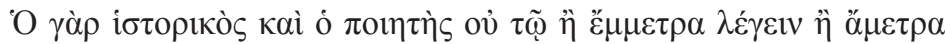

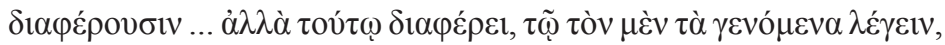

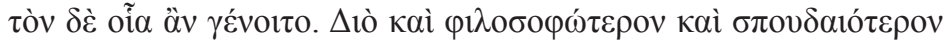

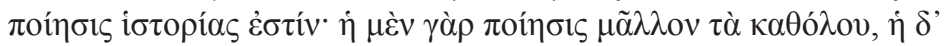

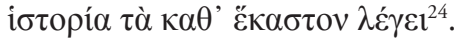

O entretenimento proporcionado pela História é também notado por Plínio-o-Moço, que afirma que historia quoquo modo scripta delectat ${ }^{25}$. Por seu lado, Vitrúvio, ao escrever sobre arquitectura, lamenta-se da sua matéria por ser árida, pois

${ }^{22}$ Referindo-se a Tácito, Woodman realça esta estratégia em episódios isolados descritos no meio de outras narrativas (de batalhas ou viagens): irmáos que se encontram no campo de batalha e decidem não lutar entre si, um narrado em Hist. 3.51 e outro em Hist. 3.25.2-3. Tem ainda especial interesse a aproximação dos episódios em que, nos Annales, Germânico chega ao campo onde jazem as legiōes de Varo, a devastação aí encontrada (1.61-2), e a imagem semelhante que aparece nas Historiae, no momento em que Vitélio visita Bedríaco e depara com um cenário de devastação idêntico (Hist. 2.70): Woodman 1998 13-14 e 70-85.

${ }^{23}$ Cícero (Leg. 1.2.5) mostra que são diferentes: enquanto a História mostra a ueritas, a poesia tem como finalidade a delectatio.

${ }^{24}$ Poética, 1451 b: 'O historiador e o poeta não diferem pelo facto de um escrever em prosa e o outro em verso (...). Diferem é pelo facto de um relatar o que aconteceu e outro o que poderia acontecer. Portanto, a poesia é mais filosófica e tem um carácter mais elevado do que a História. É que a poesia expressa o universal, a História o particular'; v. Halliwell 1989 153-154.

${ }^{25}$ Ep. 5.8.4. Em 5.8.5, testemunha o trabalho de historiador feito pelo tio: historias et quidem religiosissime scripsit; v. Fantham 1989a 292. 
historiae per se tenent lectores; habent enim nouarum rerum uarias expectationes (Vitr. 5.1). Quintiliano refere-se às qualidades da História que devem ser cultivadas pelo orador, mas com algumas precauçóes: historia (...) alere oratorem quodam uberi iucundoque suco potest; (...) plerasque eius uirtutes oratori esse uitandas (Inst. 10.1.31). Por isso, desaconselha-se a brevidade de Salústio e, apoiado em Cícero, o uso de Tucídides e de Xenofonte ${ }^{26}$ como modelos a seguir. Noutro passo, Quintiliano afirma que licet tamen nobis in digressionibus uti uel historico nonnunquam nitore (Inst. 10.1.33). Outra vantagem de saber História é o conhecimento de factos e precedentes dos casos em litígio (ex cognitione rerum exemplorumque ${ }^{27}$ ).

No entanto, o testemunho mais significativo acerca da ideia de História na Antiguidade romana é de Cícero ${ }^{28}$. No De Oratore, defende-se que o atributo essencial do historiador é non esse mendacem (de Orat. 2.12.51). Esta característica também é mencionada na Rhetorica ad Herennium, que considera a historia uma das três partes da exposição dos factos (in negotiorum expositione), ao lado da fabula e do argumentum (em grego, historia, mythos e plasma): desta oposição, ressalta a qualidade da exposição do real, promovida pela História (gesta res) e a ficcionalidade (ficta res) do argumentum ${ }^{29}$.

O mesmo de Oratore fornece, pela fala de António, uma perspectiva diacrónica da História Romana:

Erat enim historia nibil aliud nisi annalium confectio, cuius rei, memoriaequepublicaeretinendaecausa, abinitio rerum Romanarum usque ad P. Mucium pontificem maximum, res omnes singulorum annorum mandabat litteris pontifex maximus, referebatque in

${ }^{26}$ Inst. 10.1.32: refere-se que Salústio não é um autor adequado para servir de fonte para um discurso porque um orador tem de se dirigir a um juiz que não está preparado (ineruditus) para a beleza do discurso. Em alternativa a Salústio, o estilo de Lívio (lactea ubertas) é mais próprio para o uso da oratória porque o ouvinte non speciem expositionis, sed fidem quaerit.

${ }^{27}$ Inst. 10.1.34; v. Fantham 1989a 288-289.

${ }^{28}$ V. Rambaud 1953 e Fantham $1989 b$ 234-235 e 238.

${ }^{29}$ Definido assim: argumentum est ficta res quae tamen fierit potuit, uelut argumenta comoediarum (Rhet. Her. 1.8.13); v. Fantham 1989b 228-229. A aproximação dos factos históricos à fabula é feita por Cícero nestes termos: rerum gestarum historiam (...) quasi fabulam rerum euentorumque (Fam. 5.12.6). Cf. Leg. 1.2.5, onde o mesmo autor diz que até em historiadores como Heródoto e Teopompo há muitas fabulae. 
album, et proponebat tabulam domi, potestas ut esset populo cognoscendi, hique etiam nunc Annales Maximi nominantur. Hanc similitudinem scribendi multi secuti sunt, qui sine ullis ornamentis monumenta solum temporum, hominum, locorum gestarumque rerum reliquerunt (2.12.52-53).

$\mathrm{O}$ orador ilustra o que diz nomeando autores gregos que exemplificam essa tendência (Ferecides, Helânico, Acusilau), tal como Catão, Pictor e Pisão, autores romanos qui neque tenent, quibus rebus ornetur oratio (...) et, dum intellegetur, quid dicant, unam dicendi laudem putant esse breuitatem. O exemplo de Antípatro também é significativo: historiae maiorem sonum uocis uir optimus (...): ceteri non exornatores rerum, sed tantummodo narratores fuerunt ${ }^{30}$. É evidente a preocupação demonstrada pela personagem de Cícero com o embelezamento do discurso historiográfico: ornamentis, ornetur, exornatores. Cátulo, o interlocutor de António, concorda e exemplifica o seu ponto de vista com Célio, um homem que neque distinxit historiam uarietate locorum, neque uerborum collocatione et tractu orationis leni et aequabili perpoliuit illud opus ${ }^{31}$.

António não se admira porque ista res adhuc nostra lingua illustrata non est $t^{32}$. Segue-se uma discussão sobre autores gregos, em que Tucídides é o mais elogiado. António confessa que nos tempos livres costuma ler (legere soleo), náo com o objectivo de se preparar para discursos, mas por simples deleite (sed delectationis causa, 2.13.59), o que revela com bastante clareza que a finalidade social e cultural da História, em Roma, era a evasão e o deleite estético.

As propriedades retóricas da História são exploradas ao pormenor pelo mesmo António, ao referir-se à importância (munus) que este género ${ }^{33}$ tem para a Retórica:

30 2.12.53 e 54; cf. Leg. 1.2.6-7, onde são referidos os mesmos autores, juntamente com outros: Fábio, Catão, Pisão, Fânio, Verónio, Antípatro, Clódio, Aselião, Célio, Macro, Sisena. Em carta a Luceio, Cícero expressa os mesmos sentimentos de desinteresse pela fixação de simples eventos: etenim ordo ipse annalium mediocriter nos retinet, quasi enumeratione fastorum (Fam. 5.12.5).

${ }^{31}$ De Orat. 2.13.54. O aludido Antípatro também tem uma obra sine nitore (Leg. 1.2.6).

${ }^{32}$ De Orat. 2.13.55. Esta ideia também surge em Leg. 1.2.5: dest enim historia litteris nostris.

${ }^{33}$ De facto, em Cícero, a historia é um genus: de Orat. 2.13.55 e Leg. 1.2.5. 
uidetisne, quantum munus sit oratoris historia? Haud scio, an flumine orationis et uarietate maximum. Neque tamen eam reperio usquam separatim instructam rhetorum praeceptis: sita sunt enim ante oculos. Nam quis nescit, primam esse historiae legem, ne quid falsi dicere audeat? Deinde ne quid ueri non audeat? Ne qua suspicio gratiae sit in scribendo? Ne qua simultatis? ${ }^{34}$

É importante, neste aspecto, recordar o pedido que Cícero sem melindre faz a Lúcio Luceio (Fam. 5.12.6). Ao pedir uma história dos seus feitos no consulado, sugere que o amigo não ponha limites no favorecimento (a mesma gratia que acaba de censurar):

Haec scilicet fundamenta nota sunt omnibus; ipsa autem exaedificatio posita est in rebus et uerbis. Rerum ratio ordinem temporum desiderat, regionum descriptionem; (...) et cum de euentu dicatur, ut causae explicentur omnes, uel casus, uel sapientiae, uel temeritatis, hominumque ipsorum non solum res gestae, sed etiam, qui fama ac nomine excellant, de cuiusque uita atque natura (de Orat. 2.15.63).

Na carta a Luceio, Cícero não se inibe de dar alguns conselhos sobre o modo como o amigo poderia escrever a história do seu consulado, período no qual poderá encontrar grande variedade de motivos, como perfídias, intrigas, traiçóes de muitos a que Cícero esteve sujeito (multorum in nos perfidiam, insidias, proditionem notabis). São estes os temas que despertam o interesse do leitor:

nihil est enim aptius ad delectationem lectoris, quam temporum uarietates fortunaeque uicissitudines; quae (...) in legendo tamen erunt iucundae (Fam. 5.12.4).

Insiste na mesma ideia em 5.12.5:

at uiri saepe excellentis ancipites uariique casus habent admirationem, exspectationem, laetitiam, molestiam, spem, timorem; si uero exitu notabili concluduntur, expletur animus iucundissima lectoris uoluptate ${ }^{35}$.

${ }^{34}$ De Orat. 2.15.62. Cf. Leg. 1.2.5 e recorde-se de Orat. 2.12.51.

${ }^{35}$ Políbio (12.25) também critica a dramatização da História, não deixando, apesar disso, de ser um agente desse processo. 
O registo do passado e a celebração da fama dos homens também é, como testemunhava Cícero ${ }^{36}$, um elemento caracterizador da História ${ }^{37}$. Por seu lado, Quintiliano diz: ad memoriam posteritatis et ingenii famam componitur (Inst. 10.1.31); e de acordo com a Rhetorica ad Herennium: historia est gesta res, sed ab aetatis nostrae memoria remota (Rhet. Her. 1.8.13).

Aristóteles defende que a imitação através da narração e em verso tem uma estrutura diferente da narrativa histórica:

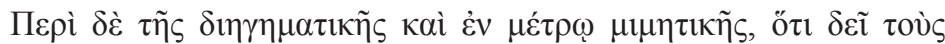

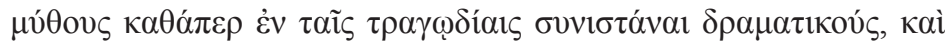

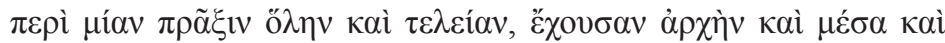

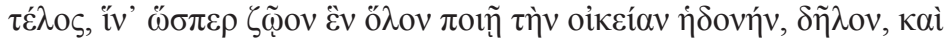

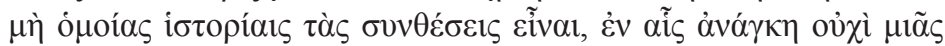

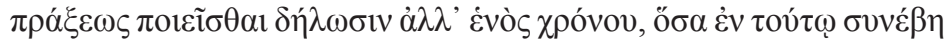

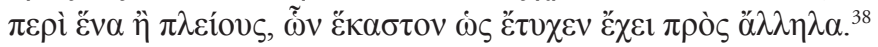

Pelas ideias que ficam sublinhadas, penso que a busca de evasão a que a História tinha de responder, levando o leitor para paisagens e países distantes e para junto de povos desconhecidos, corresponde, grosso modo, à evasáo que o romance propicia nos nossos dias. Assim, é precisamente a vontade de responder ao gosto do público (delectatio) que traz um carácter de ficcionalidade à historiografia antiga, mais especificamente à romana, pelo que "[ancient historians] should be compared with Latin poets" (Woodman 1998 18). Daqui resulta o esbatimento do nível de diferenciação entre História e literatura — a ficcionalidade —, permitindo ainda a eliminação da fronteira de uma em face da outra; por outro lado, este facto não só justifica como legitima

${ }^{36}$ De Orat. 2.15.63 e Leg. 1.3.8-9; em Leg. 1.2.5, surge a ideia de escrever História para celebrar a pátria.

${ }^{37}$ Cf., para a diferença entre Heródoto e Tucídides, Nagy 1989 8-9.

38 Poética, 1459a: 'No que respeita à imitação através da narração e em verso, é necessário, como nas tragédias, construir enredos dramáticos e em volta de uma acçáo única e completa que tenha princípio, meio e fim, para que, tal como um ser vivo único e inteiro, produza um prazer próprio, e, evidentemente, a sua estrutura não deve ser igual à das narrativas históricas, nas quais é forçoso que se faça a exposição não de uma só acção mas de um só período de tempo, de tudo o que, nesse tempo, aconteceu a uma ou várias pessoas, cada uma das quais se liga às outras como o acaso determinou.' De notar a acção histórica definida pelo acaso (cf. o casus, as uarietates e as uicissitudines a que Cícero se referia). 
o testemunho de alguns autores antigos acerca da História. Como demonstrei, escritores de diferentes épocas apresentam uma perspectiva uniforme de como se pensava a História na Antiguidade. 


\section{O Plano do Historiador}

Sintetizo nesta secção os passos em que o narrador dos Annales assume uma atitude doutrinária, ou seja, disserta sobre a qualidade e propriedades da História. A esses momentos em que o narrador faz excursos na história para se exibir ao leitor, e que configuram o seu protagonismo, designo 'plano do historiador' ${ }^{39}$. Esses momentos identificam-se por uma reflexão sobre o modo como apresenta a História, na sua redacção e selecção, pela referência a outros historiadores, de reconhecido valor ${ }^{40}$, a par de consideraçóes acerca do lugar da sua obra na produção historiográfica romana, pela teorização da História e da epistemologia, e pelo registo moralizante e até irónico que imprime à narrativa, utilizando a primeira pessoa do singular ou do plural (Pelling 2009 152-154; cf. Gilmartin 1975).

Num passo do livro II, o narrador lamenta que Armínio não tenha sido referido pela historiografia grega, e que mesmo a romana quase não lhe faça menção. Tal consideração é pretexto para uma breve caracterização de duas formas de tratar do registo do passado, a grega e a romana:

Graecorum annalibus ignotus, qui sua tantum mirantur, Romanis haud perinde celebris, dum uetera extollimus recentium incuriosi. (2.88.3)

${ }^{39}$ Distinto do plano da história, aquele em que se narram os episódios de carácter histórico propriamente dito (caracterizados por um conjunto de isotopias que os une semanticamente, sendo a categoria personagem aquela que mais significativamente identifica esses episódios). A utilizaçáo do termo episódio segue os preceitos da teoria semiótica da narrativa, tal como recordados por Reis — Lopes 2000 s.v. "episódio": "unidade narrativa não necessariamente demarcada exteriormente (...) na qual se narra uma acção autónoma em relação à totalidade da sintagmática narrativa, acção essa que se conexiona com o todo em que se insere por meio de um qualquer factor de redundância (a personagem que protagoniza os diferentes episódios de uma narrativa, o espaço em que eles se desenrolam, as dominantes temáticas que regem a narrativa, etc.)."

${ }^{40}$ Lembro apenas os historiadores do proémio (clari scriptores; decora ingenia, 1.1.2) e a referência a Lívio (eloquentiae ac fidei praeclarus in primis, na voz de Cremúcio Cordo, em 4.34.3) e a Salústio (rerum Romanarum florentissimus auctor, 3.30.2). 
Esta visão de exaltação do passado em detrimento da História recente pode ser entendida como um dos motivos por que o historiador resolveu redigir a História desde a morte de Augusto, traçando um percurso político de uma Roma em que o novo regime, o principado, se institucionaliza e é aceite por todos (1.3.7).

Ainda assim, a exaltação do passado e da historiografia que o registou náo deixa de ser feita pelo narrador dos Annales, uma entidade preocupada por náo poder dar ao leitor aquilo que sabe que ele gostaria de ler, nomeadamente em contraste com esses autores que escreveram a História de Roma em períodos ricos em acontecimentos diversos e interessantes (ou seja, durante a República; v. Gowing 2009 21-22). São célebres estas consideraçóes no livro IV:

Pleraque eorum quae rettuli quaeque referam parua forsitan et leuia memoratu uideri non nescius sum: sed nemo annalis nostros cum scriptura eorum contenderit qui ueteres populi Romani res composuere. ingentia illi bella, expugnationes urbium, fusos captosque reges, aut si quando ad interna praeuerterent, discordias consulum aduersum tribunos, agrarias frumentariasque leges, plebis et optimatium certamina libero egressu memorabant: nobis in arto et inglorius labor; immota quippe aut modice lacessita pax, maestae urbis res et princeps proferendi imperi incuriosus erat. (4.32.1)

A redacção desses acontecimentos, apesar de aborrecidos, é necessária. Há motivos que impulsionam essa necessidade, sendo a primeira a falta de imparcialidade dos outros, notada no primeiro capítulo da obra, estruturado em três parágrafos, correspondendo a cada um deles um motivo programático: a História de Roma (1.1.1), um parecer sobre a historiografia romana (1.1.2), e o "índice" ${ }^{41}$ (1.1.3) desta obra:

Vrbem Romam a principio reges habuere; libertatem et consulatum L. Brutus instituit. dictaturae ad tempus sumebantur; neque decemuiralis potestas ultra biennium, neque tribunorum militum consulare ius diu ualuit. non Cinnae, non Sullae longa dominatio; et Pompei Crassique potentia cito in Caesarem, Lepidi atque

${ }^{41}$ Podem observar-se as linhas temáticas que orientam a estrutura da obra: 1.2.1-4.1: pauca de Augusto; 1.4.2-5.4: extrema [de Augusto]; 1.6.1: Tiberii principatum; de 7.1 .1 até ao fim: et cetera. Leeman 1973 188-189 e Woodman 1998 22-23, pace Miller 1992 105, Goodyear 1972108 e 125, e Syme 1958304. 
Antonii arma in Augustum cessere, qui cuncta discordiis ciuilibus fessa nomine principis sub imperium accepit. sed ueteris populi Romani prospera uel aduersa claris scriptoribus memorata sunt; temporibusque Augusti dicendis non defuere decora ingenia, donec gliscente adulatione deterrerentur. Tiberii Gaique et Claudii ac Neronis res florentibus ipsis ob metum falsae, postquam occiderant, recentibus odiis compositae sunt. inde consilium mihi pauca de Augusto et extrema tradere, mox Tiberii principatum et cetera, sine ira et studio, quorum causas procul habeo.

O primeiro sector resume a história de Roma numa seriação cronológica de formas de governo, referidas em registo metonímico - reges (metonímia por Monarquia) e libertatem et consulatum (metonímias por República) são regimes políticos que deram lugar a outros ${ }^{42}$, mas de menor duração ${ }^{43}$ (e que vão alternar com a República: dictatura, potestas, ius, dominatio, potentia). Estes regimes confluem para uma nova forma política, o principado ${ }^{44}$, e tal confluência surge no âmbito da representaçáo retórica com uma expressão física de movimento, vincada pela construção de in com acusativo: in Augustum cessere ${ }^{45}$.

O segundo parágrafo é a explicaçáo dos motivos por que o narrador não precisa de se referir a assuntos tão antigos: foram já tratados por autores ilustres. Acontece, porém, que na época de Augusto esses escritores foram sendo desvirtuados pela adulação crescente, tendo-se por isso chegado ao ponto em que não só os acontecimentos dos principados de Tibério, Gaio, Cláudio e Nero foram redigidos em termos ficcionais por causa do medo, como também, depois que eles morreram, a História sofreu a influência de animosidades recentes.

${ }^{42}$ A concatenação de sintagmas é feita em seriação cronológica, sem que se exprimam os motivos que levam à queda de uns e à adopção de outros regimes políticos, mas importa lembrar, como o narrador faz nos parágrafos seguintes, que não é o seu objectivo explicá-los. Noutra perspectiva, nota-se que os regimes políticos despóticos fizeram, desde sempre, parte da história de Roma.

${ }^{4}$ A pouca duração de cada um destes regimes é expressa pelas expressóes sumebantur, neque... neque diu ualuit, non... non longa.

${ }^{44}$ A ideia em nomine principis sub imperium accepit é repetida em 1.9.5: non regno tamen neque dictatura, sed principis nomine constitutam rem publicam (cf. 3.56.2).

${ }^{45} \mathrm{O}$ movimento de recepção do poder acabará por revelar-se uma isotopia (da primeira parte) dos Annales, como se estuda no Cap. 2, sec. 1. 
O terceiro parágrafo deste capítulo é a assunçáo, por parte de uma primeira pessoa (mihi, habeo), do papel de historiador, a que se tinha tido acesso, até agora, pelo juízo de valor das suas consideraçóes sobre a historiografia antecedente - ressalta desse parecer um conhecimento de outros escritos históricos — este é, pois, um escritor informado, conhecedor de várias fontes, como se verá a seguir.

Também no proémio das Historiae se mostra a necessidade de redigir uma História que se inicia em 69 d.C., mas não de épocas anteriores, porque até à batalha de Áccio houve muitos historiadores que o fizeram com eloquência e liberdade:

nam post conditam urbem octingentos et uiginti prioris aeui annos multi auctores rettulerunt ${ }^{46}$, dum res populi Romani memorabantur pari eloquentia ac libertate: postquam bellatum apud Actium atque omnem potentiam ad unum conferri pacis interfuit, magna illa ingenia cessere; simul ueritas pluribus modis infracta, primum inscitia rei publicae ut alienae, mox libidine adsentandi aut rursus odio aduersus dominantis: ita neutris cura posteritatis inter infensos uel obnoxios. sed ambitionem scriptoris facile auerseris, obtrectatio et liuor pronis auribus accipiuntur; quippe adulationi foedum crimen seruitutis, malignitati falsa species libertatis inest (Hist. 1.1.1-2).

Porém, estas decisões de suprir o que falta dizer com imparcialidade trazem a questáo da falta de originalidade dos feitos narrados. Nos Annales, o autor textual, a propósito do tipo de acçóes que descreve, diz sobre elas:

ceterum ut profutura, ita minimum oblectationis adferunt. nam situs gentium, uarietates proeliorum, clari ducum exitus retinent ac redintegrant legentium animum: nos saeua iussa, continuas accusationes, fallaces amicitias, perniciem innocentium et easdem exitii causas coniungimus, obuia rerum similitudine et satietate (4.33.3).

A falta de verdade das histórias que circulavam e a necessidade de celebrar as virtudes, e os seus exemplos, são a explicação para que Tácito encontre espaço entre os historiadores romanos para a sua obra. No livro III lê-se o seguinte propósito moral:

Exequi sententias hand institui nisi insignis per honestum aut notabili dedecore, quod praecipuum munus annalium reor ne

46 Tácito fala a partir do ano 69. 
uirtutes sileanturutque prauis dictis factisque ex posteritate et infamia metus sit. ceterum tempora illa adeo infecta et adulatione sordida fuere ut non modo primores ciuitatis, quibus claritudo sua obsequiis protegenda erat, sed omnes consulares, magna pars eorum qui praetura functi multique etiam pedarii senatores certatim exsurgerent foedaque et nimia censerent. ${ }^{47}$

A matéria histórica dos annales tem de ser ilustre e não se confinar a repetir os diurna acta (13.31.1); aliás, em 4.4.3 e 4.6.1, por exemplo, o narrador reflecte acerca de assuntos que merecem ser recordados para a posteridade. Essa mesma preocupação com a memória das geraçóes futuras surge com grande vigor em 4.35.4, depois de narrado o caso de Cremúcio Cordo ${ }^{48}$ :

quo magis socordiam eorum inridere libet qui praesenti potentia credunt extingui posse etiam sequentis aeui memoriam. nam contra punitis ingeniis gliscit auctoritas, neque aliud externi reges aut qui eadem saeuitia usi sunt nisi dedecus sibi atque illis gloriam peperere.

Noutro passo, e apesar do enfado que possa causar ao leitor, o narrador critica quem não recorda nas suas obras a morte e o castigo de muitos homens:

originem [de Seio Quadrato] non repperi. neque sum ignarus a plerisque scriptoribus omissa multorum pericula et poenas, dum copia fatiscunt aut quae ipsis nimia et maesta fuerant ne pari taedio lecturos adficerent uerentur: nobis pleraque digna cognitu obuenere, quamquam ab aliis incelebrata (6.7.5).

Depois ilustra esta sua empresa com um caso isolado, que surge como exemplo de virtude e rectidão moral: Marco Terêncio assume a amizade com Sejano numa época em que todos a desmentiam.

Destas observações decorre também a manifestação da tendência moralizadora que caracteriza a obra, de uma forma geral, e que explica o estilo sentencioso de alguns passos - nomeadamente no fecho de alguns episódios, como que a explicar os motivos por que os acontecimentos ocorrem, ou a generalizar uma lição

${ }^{47}$ Ann. 3.65.1-3. Sobre este capítulo, v. Woodman 1998 86-103, Syme 1958 520, Luce 1991 e McCulloch Jr. 1991.

${ }^{48}$ Objecto de análise no Cap. 3, sec. 4. 
que deles resulte ${ }^{49}$. Estes são momentos em que o narrador da história se mostra alguém preocupado com a acçáo humana e que pretende mostrar o que se passou para servir de liçáo para o presente e para o futuro ${ }^{50}$.

Ainda neste âmbito, refiram-se alguns dos passos em que se mostra a ironia do narrador ${ }^{51}$, usada talvez para reflectir a amargura da desistência de alguém que náo pode mudar o que acha mal. Os exemplos são inúmeros:

nisi forte clarissimo cuique pluris curas, maiora pericula subeunda, delenimentis curarum et periculorum carendum esse (2.33.3); nicta est sine dubio lex, sed neque statim et paucis suffragiis, quo modo etiam cum ualerent leges uincebantur (2.51.2); quid enim aliud laeso patrono concessum quam ut centesimum ultra lapidem in oram Campaniae libertum releget? (13.26.2).

\subsection{As Fontes dos Annales ${ }^{52}$}

Como referido, o plano doutrinário do narrador manifesta-se ainda nos passos em que Tácito refere de forma explícita as suas fontes, evidenciando indícios de que a obra resulta de um trabalho de investigação histórica. Em termos retóricos, há que notar um padrão discursivo que uniformiza, por assim dizer, a citaçáo de fontes. Os verbos que expressam o resultado da pesquisa do narrador sáo reperio e refero, quando diz que refere o que os outros dizem; o que exprime o que os historiadores transmitem é trado (ou compostos deste verbo).

De uma maneira simplificadora, as fontes de Tácito podem distinguir-se como oficiais, bibliográficas e directas ${ }^{53}$. São fontes

${ }^{49}$ A sententia é uma uox uniuersalis que é aplicada e tem interesse além de um contexto ou discurso particular, como diz Quintiliano (Inst. 8.5.3). A propósito do pendor sentencioso dos livros de Tibério, v. Sinclair 1995.

50 Exemplos dessas sententiae são frases como: dum ueritati consulitur, libertas corrumpebatur (1.75.1) e fato potentiae raro sempiternae, an satias capit aut illos cum omnia tribuerunt aut hos cum iam nibil reliquum est quod cupiant (3.30.4).

${ }^{51}$ Sobre a ironia nos Annales, existe o estudo de O'Gorman 2000.

52 A discussão acerca das fontes dos Annales é antiga e tem produzido diversos trabalhos: Syme 1958 271-303, Syme 1988 199-222, Benario 1975 80-87, Devillers 2003, Fabia 1967; v. também Gowing 2009 e Woodman 2009.

${ }^{53}$ A identificação das fontes tem em conta unicamente as que são expressas ao longo da obra, excluindo hipóteses, algumas perfeitamente aceitáveis, como o uso dos discursos de outros imperadores além de Tibério. 
oficiais as que são identificadas como diurna scriptura actorum (3.3.2) ou diurna acta (13.31.1), possivelmente os jornais da época $^{54}$, os publica acta (12.24.2) ou acta senatus (15.74.3), considerados uma espécie de Diário da República, e os discursos e cartas de Tibério, que parece terem sido publicados e disponíveis ao público (em 1.81.1, o historiador queixa-se da falta de informação destes discursos; em 2.63.3, dá conta da existência de um discurso em que Tibério testemunha a grandiosidade de Marobóduo, a violência dos povos a ele subjugados, como esteve próximo de Itália, e os planos para a sua destruição; em 6.6.1, cita em oratio recta uma carta de Tibério).

As fontes bibliográficas são as que, de longe, levantam mais problemas, mas são as mais interessantes de analisar. É preciso distinguir entre os historiadores citados e a fórmula de referência anónima. Dos primeiros, destaca-se Plínio-o-Velho, referido três vezes. A primeira, no livro I, testemunha que escreveu uma história dos povos Germanos:

tradit C. Plinius, Germanicorum bellorum scriptor, stetisse apud principium ponti laudes et grates reuersis legionibus habentem (1.69.2).

No livro XIII, Plínio é referido juntamente com Clúvio Rufo, sendo ainda citado Fábio Rústico:

Fabius Rusticus auctor est scriptos esse ad Caecinam Tuscum codicillos, mandata ei praetoriarum cohortium cura, sed ope Senecae dignationem Burro retendam: Plinius et Clunius nibil dubitatum de fide praefecti referunt; sane Fabius inclinat ad laudes Senecae, cuius amicitia floruit (13.20.2) ${ }^{55}$.

O passo termina de modo conciliatório e considerado inovador para a historiografia da época:

nos consensum auctorum secuturi, quae diuersa prodiderint sub nominibus ipsorum trademus.

Clúvio Rufo e Fábio Rústico são referidos novamente em 14.2.1-2; Fábio Rústico é de novo citado em 15.61.3.

${ }^{54}$ Também referidos em 16.22.3, mas não com a ideia de terem servido de fonte à matéria histórica.

55 Fábio Rústico é louvado pela sua eloquência no $A g$. 10.3. 
No livro XV, Plínio é citado a propósito da narração do plano de conjura de Pisão durante os jogos de Ceres do ano 65: o autor textual conta a versão quod C. Plinius memorat (15.53.4). No entanto, o historiador mostra a estranheza dessa versão, mas (talvez por uma questão de transparência) não a oculta, apesar de ela parecer absurda (está em causa o facto de Antónia ter emprestado o seu nome e arriscado a reputação por um projecto de Pisão, conhecido pelo amor à esposa - a menos que o desejo pelo poder brilhe mais forte do que qualquer desejo ${ }^{56}$ ).

Outros dois autores merecem referência do autor textual. Agripina Menor escreveu uns commentarii de que o autor se serve para contar que Agripina Maior pediu um marido a Tibério:

id ego, a scriptoribus annalium non traditum, repperi in commentariis Agrippinae filiae quae Neronis principis mater uitam suam et casus suorum posteris memorauit (4.53.2).

O general Corbuláo é citado em 15.16.1, por ter deixado uma história da guerra dos Partos em que Tácito se baseia.

Nas fontes bibliográficas há ainda a realçar as alusóes a autores não citados. Referidos como auctores rerum, plerique... alii, quidam, ou scriptores, os passos mais significativos onde aparecem são aqueles em que o narrador confessa não ter dados para completar as suas informaçóes ou em que apresenta versóes alternativas à que escolhe como principal. Os passos em que tal ocorre são principalmente: $1.29 .4,1.81 .1,2.40 .2,2.88 .1,4.10 .1$, 4.11.1, 4.53.2, 4.65.6, 5.9.2, 12.67.1, 13.17.2, 14.2.2, 15.38.1, 16.6.1. Esse facto concorre para a caracterização do narrador dos Annales como alguém informado, capaz de se lamentar das suas pesquisas quando não têm os resultados pretendidos.

Finalmente, refiram-se as testemunhas directas, que presenciaram os acontecimentos (11.27), e os rumores (3.16.1, $4.10 .1,4.11 .1,11.27,15.41 .1)$ ou relatos $(3.16 .1,11.34 .1,15.65)$ que também serviram de fontes aos Annales e neles são citados com alguma regularidade. ${ }^{57}$ De uma maneira geral, o papel dos rumores na economia da narrativa é de extrema importância, pois

${ }^{56}$ nobis quoquo modo traditum non occultare in animo fuit, quamuis absurdum uideretur aut inanem ad spem Antoniam nomen et periculum commodauisse, aut Pisonem notum amore uxoris alii matrimonio se obstrinxisse, nisi si cupido dominandi cunctis adfectibus flagrantior est (15.53.4).

${ }^{57}$ V. Miller 1992 8-10 e Verdejo Sánchez 2001. 
através deles o autor textual matiza o pensamento da época a que a sua história se reporta, ao mesmo tempo que, numa perspectiva literária, podem ser entendidos como uma espécie de coro grego, pois cumprem a mesma função que este exerce numa tragédia.

\subsection{Fidelidade às fontes}

Existem três evidências epigráficas que provam a relação de Tácito com as fontes: a Tabula Siarensis (registo de honras decretadas ao falecido Germânico, em 19), o Senatus Consultum de Cn. Pisone Patre (registo do julgamento do ano 20 que levanta um problema de datação) e umas tábuas de bronze, descobertas no século XVI em Lião, com o discurso de Cláudio ao senado em 48, recordado em Ann. 11.24.

De uma perspectiva retórica, estas fontes têm confirmado a informação fornecida pelo historiador, de onde tem resultado a confiança no texto de Tácito. A narrativa tacitiana trabalha estas fontes, alterando-as de modo a conferir-lhes um cunho pessoal. Por exemplo, a comparação do texto de Tácito e o do senatus consultum de Pisone Patre apresenta uma discrepância na data do julgamento de Pisão - tal pode dever-se, mais do que a um lapso, à manipulação dos dados para a construçáo de um efeito dramático mais forte ${ }^{58}$.

O trabalho de interpretação de fontes também faz parte da tarefa do historiador, como o próprio assume em 3.3.3, 4.10.1, 4.57.3, ou 16.6.1. Nestes passos, o autor dá versóes alternativas dos acontecimentos, mas inclina-se para uma interpretaçáo própria e credível, usando o espírito crítico (crediderim). De facto, o cuidado no uso das fontes é demonstrado exemplarmente em 13.20.2, onde evidencia certa desconfiança em relação ao louvor de Fábio Rústico a Séneca, por serem amigos.

Desta síntese decorre que a concepção que Tácito tem de História está de acordo com o panorama conceptual descrito na secção anterior, fazendo uso dela não só para entreter os leitores, mas também - e principalmente - para dar exemplos a seguir, e denunciar comportamentos indignos e infames na História recente. A preocupação com a memória é outro vector fundamental dos Annales, o que justifica a atenção que o narrador dá ao silenciar de oradores, senadores e escritores (cf. Cap. 3, sec. 4).

\footnotetext{
${ }^{58}$ Sobre a utilização do decreto do senado, cf. Barnes 1998, Damon 1999a e $b$.
} 
Capítulo II

Avgvistae Conscientia, CAesaris Favor 
Os Annales assentam numa estrutura analística em que os acontecimentos são referidos ano a ano, numa sequência cronológica. Desta opção resulta uma construção fragmentária da obra, pois a narração de um episódio é interrompida para se narrar outro que tenha ocorrido nesse ano; a narrativa dos acontecimentos é retomada depois, já noutro ano. Esta sucessão tem um efeito de simultaneidade das acçôes, configurando ao mesmo tempo a duração dos episódios ${ }^{1}$. A duração de algumas acçóes é sustentada pela recorrência com que os assuntos são abordados e náo, como frequentes vezes acontece, pela narração total de uma intriga, baseada em dícticos temporais ${ }^{2}$. Por isso, a estrutura analística pode ser analisada tendo em conta o seu papel para a dinamizaçáo da categoria tempo nos Annales, ainda que outras perspectivas possam ser operacionalizadas, nomeadamente quanto à selecção e disposição do tipo de informação veiculada, como refere R. Martin 1981 104:

Selection (including the powerful weapon of omission), arrangement, emphasis lie entirely within the historian's choice. The shape that he finally gives to his work is an important instrument of a historian's interpretation of events. ${ }^{3}$

${ }^{1}$ Há acções, nomeadamente do âmbito dos assuntos externos, que são narradas extrapolando a divisão temporal do ano consular. Nessas ocasióes, normalmente de pequena extensão, o narrador chama a atençáo para o facto — 6.38.1, 12.40.5, 13.9.3. Com essa aproximação não se quebra o fio condutor (cf. 4.71.1).

${ }^{2}$ Aqui se incluem pequenas mas significativas apariçóes de personagens em cenas de que tomam parte e, no adensar da trama, mais não seguem do que o caminho para o clímax desastroso que leva à morte. Não é, pois, despiciendo que em torno de uma personagem como Trásea Peto se vá construindo, progressivamente, uma atmosfera patética que culmina na sua perdição. Com efeito, à medida que vai aparecendo, Trásea Peto vai assumindo certo protagonismo na oposição a Nero, ao mesmo tempo que adquire prestígio e simpatia do leitor, surge como um exemplo de lição de vida (v. 13.49, 14.12.1, 48.3-49.3, 15.20.2-22.1, 15.23.4, 16.21.1-22.5, 24.1-29.2, 33.2-35.2).

${ }^{3}$ Existem alguns casos de anacronia, que concorrem para a construção de tensóes dramáticas e para dar relevo a certos acontecimentos. O leitor retém o primeiro episódio narrado num dado ano como o acontecimento mais marcante desse período. Exemplo disso é a acusação de Cremúcio Cordo, episódio que começa a ser narrado logo depois da referência aos cônsules do ano 25 (4.34.1). Para opçốes e omissóes nas falas de personagens, cf. Sinclair 
O modo como se faz a concatenação dos cenários e acçôes contribui assim para que o leitor consiga relacionar os episódios e perceber a evolução temporal das intrigas. Por isso, as partículas discursivas que fazem a transição e os apelos à memória (conseguidos por expressóes como ut retuli ${ }^{4}$, ut memoraui ${ }^{5}$, ou ut $\left.d i x i^{6}\right)$ juntam os elementos dispersos, conferindo-lhes unidade, e atenuam a fragmentariedade da narrativa. Da mesma forma, este tipo de mudança temporal dinamiza a categoria espaço, conquanto da mudança de assunto resulte náo raras vezes uma alteraçáo espacial. Assim, acontecimentos ocorridos em Roma enformam uma continuidade própria, bem como os que ocorrem, por exemplo, na Germânia, na Panónia, ou na Síria.

Se o tempo é dinamizado pela simultaneidade e duração, o espaço é dinamizado pelo movimento ou estagnação. Com efeito, muitas personagens nos Annales deslocam-se de um espaço para outro(s): Germânico, Druso, Pisão, Agripina, ou mesmo Augusto. No caso de Tibério, ainda que ele próprio viaje, o fenómeno mais significativo da personagem é a estagnação, salientada principalmente pelas constantes promessas de viagem e o seu incumprimento ${ }^{7}$. Essa falta de movimentação e o gradual isolamento numa ilha sem acesso dáo relevo à forma como governa à distância, através de cartas, e ilustram ainda a personalidade sombria e solitária do imperador ${ }^{8}$. De facto, a carta é um elemento importante na governação por servir de ponte entre Tibério e o senado, entre o isolamento e a adulação geral, desde que o príncipe se retirou para a Campânia, e daí para Cápreas ${ }^{9}$. É por isso que

1995 5: "Tacitus controls how much insight his readers have into the thoughts and motives of different individuals by regulating which historical figures are allowed to speak in his narrative".

4 Ocorrências: 2.57.2, 4.1.1, 4.21.1, 4.31.4, 6.4.1, 12.10.1, 13.32.2, 13.33.1, 15.6.3; cf. ut rettulimus 2.46.5.

${ }^{5}$ Ocorrências: 2.53.2, 3.48.2, 13.33.1, 14.29.1, 14.62.2, 16.21.1.

${ }^{6}$ Ocorrências: 3.7.2, 16.14.1; cf. ut diximus 1.33.1.

7 Tibério planeia visitar o império em 1.47 .3 (criticado por ter ficado em Roma durante os motins nas províncias em 1.47.1-2), 3.47.2 e 4.4.2. Este imobilismo parece incomodar o autor textual, preocupado com o confinamento do império em 2.61.2, 4.4.3 e principalmente 4.32.1.

${ }^{8}$ Este é, precisamente, um dos elementos que o distinguem do sobrinho Germânico, um jovem que gosta de viajar e curioso no sentido em que se interessa por aquilo que é diferente, por conhecer locais históricos e povos diferentes.

9 Mas já antes funcionava como meio de comunicação: em 4.39.1, o narrador afirma que era por carta que Tibério comunicava com Sejano, mesmo estando na sua presença. Para a avaliaçáo deste meio de mostrar Tibério por voz própria, cf. Miller 1968 1-19. 
Sejano, ao tentar convencer Tibério de que precisava de repouso longe da confusão de Roma, já pensava no controlo do príncipe porque manipularia toda a correspondência (4.41.2).

São precisamente estas duas personagens que mais significativamente ilustram a temática da ambiguidade, construída pela dicotomia aparência-realidade, quer em indícios ${ }^{10}$, quer em episódios representativos. Sejano dinamiza ainda uma temática da esperança, que perspectiva uma estruturação trágica da obra, por se tratar de um importante elemento da hybris da personagem, como se verificará.

De uma perspectiva global, é necessário reconhecer no texto tacitiano uma característica dos escritores da Antiguidade comummente aceite pelos críticos literários e historiadores, assim resumida por R. G. Collingwood 1946 43:

It is taken for granted that the historian's proper business is with acts, which come into being in time, develop in time through their phases, and terminate in time. The agent from which they flow, being a substance, is eternal and unchanging and consequently stands outside history. In order that acts may flow from it, the agent itself must exist unchanged throughout the series of its acts: for it has to exist before this series begins and nothing that happens as the series goes on can add nothing to it or take away anything from it. History cannot explain how any agent came into being or underwent any change of nature; for it is metaphysically axiomatic that an agent, being a substance, can never have come into being and never undergo any change of nature.

Por causa deste carácter substancialista da historiografia antiga $^{11}$, a tarefa do historiador "must be unmask that hypocrisy" (Martin 1981 106), pois estamos perante uma atitude em face do conhecimento do comportamento humano que difere daquela que hoje existe. Se o carácter é imutável ${ }^{12}$, quando uma pessoa

${ }^{10}$ A noção narratológica de indício é introduzida e operacionalizada por Barthes 1966.

${ }^{11}$ Diz também Syme 1958 421: "The way of thought of the ancients was prone to conceive a man's inner nature as something definable and immutable. A change in observed behaviour was therefore not a change in essence, but only a manifestation of what was there all the time".

${ }^{12} \mathrm{O}$ que se pode ver nos Characteres de Teofrasto e em Plutarco, Aratus, 49. 
muda de personalidade significa que até aí os estados anteriores da sua verdadeira índole não o revelaram. Assim, uma vez que os acontecimentos da primeira parte do principado de Tibério entram em conflito com o fim deste, o imperador não fez mais do que tentar esconder a sua verdadeira natureza. Todavia, tal consideração pode e deve ser questionada quando aplicada de forma linear ao Tibério de Tácito ${ }^{13}$. Ainda que, do meu ponto de vista, seja verdade que o autor constrói a personagem baseando-se em alguns preconceitos, é possível entender, num plano retórico, uma caracterização bastante complexa da psicologia da personagem de Tibério, homem que sofre uma degradação psicológica com o passar do tempo ${ }^{14}$.

Se todos os actos louváveis de Tibério são analisados dentro de uma perspectiva dissimulatória, até ao culminar de uma revelação da verdadeira personalidade, também é verdade que nunca se diz que motivos o imperador tem para adoptar esse comportamento. Verifica-se que é o uso de rumores e da opinião da época - e não a verdadeira voz do narrador — que dão maior vitalidade a esse ponto de vista.

Este capítulo pretende demonstrar como o texto, a partir dos capítulos dedicados a Augusto, vai configurando isotopias, que servem de base para a continuação da narrativa do principado de Tibério, principalmente no que respeita à construção de maquinaçóes de intrigas e traiçóes. A insistência em determinadas isotopias confirma a unidade e coesão textual, ao mesmo tempo que permite encontrar pistas para o estudo do estilo de Tácito.

De facto, depois de chegar ao poder, por meio de uma série de dissimulaçóes e engodos, Augusto tomou medidas que assegurassem o domínio por meio da delegação de funçôes em sobrinhos, sobrinhos-netos e enteado (que vão sendo adoptados). Neste capítulo analisa-se a construção literária das personagens mais importantes nesse processo, bem como a retórica do discurso histórico de que o autor se serve para imputar as culpas à esposa de Augusto, Lívia, a responsável pela morte dele e da sua descendência. Será ainda feita uma leitura de episódios significativos para mostrar em que medida a cumplicidade de Lívia

${ }^{13}$ Hands 1974 explica esta temática.

${ }^{14} \mathrm{~A}$ ambiguidade de Tibério reflecte-se na narrativa de Tácito, cuja prosa é tantas vezes dúbia e sujeita a difíceis interpretaçóes. O artigo de Cousin 1951 pode ser um instrumento fundamental para perceber o que é de facto dito no texto, sem que se extrapole a mensagem veiculada. 
e o apoio de Tibério $^{15}$ dinamizam uma série de acontecimentos relevantes que conduzem a desfechos trágicos, nomeadamente no caso de Germânico e do seu inimigo, Pisão.

${ }^{15}$ A expressão que serve de título a este capítulo é proferida por Domício Célere em 2.77.3. 


\section{Augusto: estabelecimento de UM MOdelo Retórico}

Com a narrativa do principado de Augusto, abre-se um caminho hermenêutico de grande relevo que estabelece, da parte do narrador para com o leitor, um conjunto de pistas e indícios para certa orientação na interpretação do principado de Augusto enquanto simulador de aparências (resultante de uma actuaçáo política insidiosa, que parte da dissimulação para a usurpação), mas que se torna operativo principalmente quando aplicado ao principado de Tibério: aparência, corrupção, tentativas de obtenção de poder por meio de intrigas, entre outras isotopias que a seguir se desenvolvem.

Augusto dinamiza pelos seus actos e atitudes um movimento continuado de ascensão, possível pela assunção de títulos e cargos de diversas magistraturas. Este movimento ascendente decorre da técnica de simulação e ilusão que Augusto usa para seduzir os diversos sectores da sociedade, conquistando um apoio generalizado e auferindo uma total ausência de oposição política e militar.

No início da secção dos Annales dedicada a Augusto ${ }^{16}$, o narrador retoma a ideia de movimento de confluência que havia expressado no proémio (Lepidi atque Antonii arma in Augustum cessere, 1.1.1):

Postquam Bruto et Cassio caesis nulla iam publica arma, Pompeius apud Siciliam oppressus exutoque Lepido, interfecto Antonio ne Iulianis quidem partibus nisi Caesar dux reliquus (1.2.1) ${ }^{17}$.

O desaparecimento ${ }^{18}$ destas personagens contribui para o isolamento de Augusto na cena política (nisi dux reliquus).

${ }^{16}$ Entre 1.2 .1 e 1.4.1, que no proémio surge com a designação pauca de Augusto; v. Cap. 1, sec. 3.

${ }^{17}$ A personagem aqui referida como Pompeio é Sexto, o filho de Pompeio Magno, a quem se aludiu em 1.1.1.

18 São diversas as expressóes que designam morte nos Annales, chegando a constituir verdadeiras imagens ligadas ao fim da vida, entendida como um percurso (começando na forma que surge no título da obra, excessus). Neste parágrafo, designam morte caesis, oppressus, interfecto. A forma exuto neste contexto também pode ter esse sentido: OLD s.v. exuo 5. Cf. Miller 1992 106-107 para observaçóes sobre o tema da morte nos parágrafos 3 e 6 . Outros substantivos ou verbos que designam morte nos Annales são: caedes, caedo, defungor, excessus, exitium, exstinguo( $r$ ), interficio, morior, mors, neco, occido, pereo, trucido. Cf. Woodman 2004 xxii e Furneaux 189671. 
O lento (paulatim) caminho para o poder (consulado, poder tribunício, responsabilidades do senado, dos magistrados e das leis, em gradação crescente) é registado por expressóes de movimento concêntrico e de sugestão insidiosa, como as formas pellixit e insurgere demonstram ${ }^{19}$ : posito triumuiri nomine consulem se ferens et ad tuendam plebem tribunicio iure contentum, ubi militem donis, populum annona, cunctos dulcedine otii pellexit, insurgere paulatim, munia senatus magistratuum legum in se trahere, nullo aduersante (1.2.1). Sublinhe-se o relevo de Augusto se elevar acima das responsabilidades das leis, um dos elementos mais significativos da evolução política de Roma ${ }^{20}$.

A morte de Bruto e Cássio aconteceu por vingança e como demonstração de pietas para com o pai de Augusto, Júlio César. Este facto (assim entendido pelos rumores espalhados na época), que levou Augusto à guerra, foi visto pela opiniáo pública como uma necessidade ${ }^{21}$, mas que poderia ter sido evitada em prol dos interesses públicos ${ }^{22}$.

Mais significativa é a ruína de Pompeio e de Lépido, pois estas personagens sáo vítimas de engodos, preparados por meios de dissimulação. Pompeio é esmagado (oppressus) na Sicília depois de ter sido enganado (deceptos) pela imagem de paz (imagine pacis), tal como Lépido havia sido pela aparência de amizade (specie amicitiae, 1.10.3). Apesar de lhe ter feito muitas concessóes (multa Lepido concessisse, 1.9.4), Augusto acabou por cortar relaçóes com Lépido e por ficar com os seus exércitos (cf. 1.12.1 e 1.1.1.).

${ }^{19}$ OLD s.v. pellicio 2. O verbo insurgo, que no presente contexto designa 'subir de classe, tornar-se proeminente' (OLD 6), também significa 'revoltarse' (OLD 5). A mesma ideia havia surgido com o verbo cessere, construído com in a reger acusativo (complemento circunstancial de lugar para onde), em 1.1.1, onde se descrevia um rápido movimento (sublinhado pelo advérbio cito) na passagem do poder das mãos de uma personagem para outra, culminando em Augusto: et Pompei Crassique potentia cito in Caesarem, Lepidi atque Antonii arma in Augustum cessere.

${ }^{20}$ De facto, o narrador sente a necessidade de contar a História do Direito em 3.25.2-28.2. A evolução da legislação acompanha a mudança de costumes, sendo sugerida a degradação moral desde o passado (uma espécie de Idade de Ouro) até ao presente. Sinclair 1995 68-71 apresenta uma discussão sobre o excurso legislativo; v. Woodman — Martin 1996 236-261.

${ }^{21}$ 1.9.3: pietate erga parentem et necessitudine rei publicae, vs 1.10 .1 , onde a reverência é tida como pretexto: pietatem erga parentem et tempora rei publicae obtentui sumpta.

${ }^{22}$ 1.10.3: sane Cassii et Brutorum exitus paternis inimicitiis datos, quamquam fas sit priuata odia publicis utilitatibus remittere. 
Augusto atraiu António para junto de si, por meio de dois pactos e do casamento com a sua irmá. Também a morte de António resulta de um engodo preparado por Augusto e é vista pelos rumores descritos pelo narrador como a expiação das penas de uma afinidade insidiosa (1.10.3). Mais uma vez, Augusto toma para si as tropas do inimigo: armaque quae in Antonium acceperit contra rem publicam uersa (1.10.2; cf. 1.1.1).

A estas personagens, reproduzindo a opinião pública do tempo, o narrador junta Hírcio e Pansa, cujos exércitos passaram para as mãos de Augusto depois que este, aparentemente, os matou: mox ubi decreto patrum fascis et ius praetoris inuaserit, caesis Hirtio et Pansa, siue hostis illos, seu Pansam uenenum uulneri adfusum, sui milites Hirtium et machinator doli Caesar abstulerat, utriusque copias occupauisse (1.10.2). A apresentação destas mortes activa um recurso típico do estilo tacitiano: depois de narrado um acontecimento, são referidas as suas causas, ligadas por conjunçóes disjuntivas (siue... seu). É comum essa alternativa basear-se na opiniấo pública, a fim de se descreverem os pensamentos divergentes da época. Uma das alternativas é mais vaga (atribuída ao fatum ou à fortuna, por exemplo), outra mais pormenorizada, frequentemente a exprimir um cariz intriguista. No caso em apreço, a alternativa insidiosa está representada na sugestiva expressão machinator doli Caesar, que caracteriza a personagem de forma particularmente negativa, ao mesmo tempo que lhe atribui profundidade psicológica, pois só alguém com estrutura mental pode usar o raciocínio para maquinar dolos ${ }^{23}$.

Em todos os casos relatados, Augusto assume o comando das legióes dos rivais, aumentando assim o seu poder militar: accipio, cedo, occupo são os verbos utilizados para exprimir esta concentraçáo dos exércitos sob a autoridade de Augusto. É por este meio que ele evita as guerras civis, flagelo da época e tema fundamental dos primeiros dez capítulos dos Annales: discordiae ciuiles (1.1.1), bella ciuium (1.3.6), arma ciuilia (1.9.3). Por outro lado, se bella e arma são sinónimos, discordia assume importância pelo sentido que encerra: Roma era uma nação onde os seus

${ }^{23} \mathrm{O}$ facto de Pansa ter sido morto por militares é também significativo da corrupção das legióes, característica de Augusto. Os militares aqui referidos - ainda que isso náo seja claro na crítica — são soldados de Augusto, como sui reflexo denuncia. A formação de nomes agentivos em -tor e -trix é muito comum em Tácito: v. Miller 1992 111-112, Goodyear 1972 221-222 e Sinclair 1995 23-25; cf. Goodyear 196830. 
cidadãos estavam desunidos (OLD s.v. dis-) pelo cor (palavra que não aparece nos Annales) ${ }^{24}$.

Para manter os militares do seu lado, Augusto cativa, corrompe e lega dinheiro às legióes: militem donis (...) pellexit (1.2.1), concitos per largitionem ueteranos, e corruptas consulis legiones (1.10.1). Em testamento, lega 1000 sestércios às coortes pretorianas, 500 às urbanas $^{25}$, mais 300 a cada legionário e militar das coortes de cidadãos $(1.8 .2)^{26}$.

Com efeito, como depois das mortes de Bruto e de Cássio já não havia exércitos do estado (nulla iam publica arma, 1.2.1), porque as tropas se repartiam pelos diversos partidos, ao voltar a uni-los em torno do seu projecto político, Augusto consegue a paz (dulcedo otii, 1.2.1), com a qual cativa toda a sociedade. Assim se explica a vulnerabilidade do senado, sem protecção militar, frente às pretensóes de Augusto (1.10.2). Do mesmo modo, Augusto atraiu o favor do povo pela redução dos preços do trigo (a annona, 1.2.1), em testamento legou 43 milhôes e meio de sestércios ao povo e à plebe (1.8.2), e havia assumido o poder tribunício ad tuendam plebem (1.2.1).

Estas manobras de sedução permitem a Augusto uma governação pacífica e sem oposição. Depois da morte dos seus adversários (destruídos pelas batalhas ou proscriçóes, 1.2.1), Augusto exalta os nobres mediante riquezas e honras, tornando cada um mais pronto para a servidão que o outro. Por isso, não é de admirar que os ingenia também tenham sido dissuadidos pela adulatio (1.1.2; cf. 1.7.1). É, pois, a promessa da paz e sua manutenção que permite ao príncipe o apoio geral ${ }^{27}$ : non aliud discordantis patriae remedium fuisse quam [ut] ab uno regeretur ${ }^{28}$. No entanto, havia os que criticavam Augusto por esta ser uma paz sangrenta (pacem sine dubio post haec, uerum cruentam, 1.10.4), recordando eles as derrotas de Lólio e Varo, e as mortes, em Roma, das famílias dos Varróes, Egnácios e Julos (Lollianas Varianasque cladis, interfectos Romae Varrones, Egnatios, Iullos, 1.10.5).

24 Se discordia é antónimo de concordia, seria de esperar que a paz alcançada por Augusto instaurasse um clima de concordia, facto a que o narrador não alude.

${ }^{25} \mathrm{O}$ segmento urbanis quinquenos é corrupto.

${ }^{26}$ Cf. 1.78.2; v. Furneaux 1896283.

27 1.4.1 (Augusto sustém a paz), 1.9.4 (remédio para as discórdias da pátria).

28 1.9.4. Estas declaraçóes, recorde-se, não representam a opinião do narrador, mas sim a opinião generalizada da população em face da crise política e social em que Roma se via mergulhada (como provam interfuit e remedium fuisse). Lembre-se este passo das Historiae: omnem potentiam ad unum conferri pacis interfuit (Hist. 1.1.1). 
Os críticos de Augusto têm ainda outra perspectiva acerca do movimento concêntrico de aquisição de poder, pois usurpação, corrupçáo e extorsão aparecem como isotopias que corrigem a ideia de unanimidade e solidariedade com o projecto de Augusto anteriormente demonstrada: corruptas (1.10.1), inuaserit, machinator doli, occupauisse, extortum (1.10.2). Pela corrupção, chega-se a uma atitude dissimulatória, denunciada pelos seus críticos, como o narrador refere após a morte de Augusto: obtentui sumpta, simulatam gratiam (1.10.1), imagine pacis, specie amicitiae (1.10.3). Passa a acreditar-se que o passado era algo perigoso, por oposição à segurança queo presente oferecia $(1.2 .1,1.4 .1)$. As províncias também preferiam o regime instaurado por Augusto à situação administrativa anterior, vista como corrupta e pouco favorável (1.2.2). E de facto já ninguém se lembrava da República (1.3.6) e todos esperavam as ordens do príncipe, exuta aequalitate (1.4.1).

A dicotomia dissimulação-aparência aparece ainda na operação de cosmética à máquina do estado: nada estava na mesma (1.4.1), mas os nomes das magistraturas eram os mesmos (eadem magistratuum uocabula, 1.3.7 $)^{29}$. Augusto apenas os mantém em aparência, como se vê na decisão de usar o título de princeps para designar as suas funçóes, em vez de rei ou ditador, ou seja, aquilo que realmente era:

non regno tamen neque dictatura, sed principis nomine constitutam rem publicam (1.9.5; cf. 1.1.1).

A morte de Augusto está também envolta em dúvidas suscitadas por rumores - terá sido Lívia a assassinar o marido. A velhice (e doença) de Augusto cedo se torna um tema recorrente: senem Augustum (1.3.4), prouecta iam senectus aegro et corpore (1.4.2), grauescere ualetudo Augusti (1.5.1) e, no mesmo passo, ele é referido como aui, em oposição a iuuenis, Agripa Póstumo. Já depois da morte de Augusto surgem referências como senili adoptione (1.7.7) e senem principem (1.8.6), mas quando, no quinto capítulo do livro $\mathrm{I}^{30}$, se narra o agravar do seu estado de

${ }^{29}$ Afirma Miller 1992109 que "much of the reality of their power was vanished."

${ }^{30}$ Este capítulo começa com a forma de sumário haec atque talia agitantibus; haec atque talia sugere que o que foi narrado antes foi um resumo, tratando-se de uma fórmula usada onze vezes nos Annales, mas só três nos livros de Tibério (em 6.22.1 ocorre haec ac talia). O sujeito do ablativo absoluto agitantibus é subentendido do contexto (outros exemplos em 1.29.2 e 5.10.1): "This happens when the noun or pronoun is antecedent to a relative, and denotes a person or persons indefinitive", como esclarece Woodcock 195974. 
saúde (grauescere ualetudo Augustỉi ${ }^{31}$, o narrador conta que algumas pessoas (quidam) suspeitavam de Lívia (scelus uxoris suspectabant), sendo essa ideia a seguir ilustrada (quippe rumor... ${ }^{32}$ ) num pequeno episódio:

quippe rumor incesserat paucos ante mensis Augustum, electis consciis et comite uno Fabio Maximo, Planasiam uectum ad uisendum Agrippam; multas illic utrimque lacrimas et signa caritatis spemque ex eo fore ut iunenis penatibus aui redderetur (1.5.1).

O episódio compreende dois espaços, o da viagem, caracterizado pelo movimento até à ilha de Planásia (Planasiam uectum), e o outro, no destino, caracterizado pela estagnação (illic). Uma vez aí chegado Augusto, o narrador descreve um cenário patético de lágrimas (multas lacrimas) e sinais de afecto (signa caritatis) de ambas as partes (utrimque). Ainda sob o governo de utrimque encontra-se a afirmação da esperança de reconciliação, de que iuuenis penatibus aui redderetur é expressão metonímica. Esta esperança (spemque ex eo fore) revelar-se-á infundada. A forma redderetur é antónima de proiecerit (1.3.4) e recorda precisamente esse passo, onde se expôs que foi por vontade de Lívia que Agripa foi para o exílio ${ }^{33}$. A viagem que Augusto agora fez transgride a disposição anterior de Lívia, o que legitima o aparte em 1.5.2, o episódio da morte de Fábio Máximo.

Fábio Máximo, casado com Márcia, é primo por afinidade de Augusto. Sabe-se que desempenhou importantes cargos de confiança do princeps. Por isso, não é de estranhar ter sido ele a única companhia de Augusto $^{34}$ na viagem para encontrar Agripa. Tratou-se de uma visita secreta, que acaba por ser revelada:

quod Maximum uxori Marciae aperuisse, illam Liniae. gnarum id Caesari; neque multo post extincto Maximo, dubium an quaesita morte, auditos in funere eius Marciae gemitus semet incusantis quod causa exitii marito fuisset (1.5.2).

$31 \mathrm{O}$ verbo incoativo exprime um facto em processamento, pelo que o estado de saúde se ia deteriorando gradualmente.

${ }^{32}$ A fórmula rumor incesserat aparece em 2.55 .6 e em 15.15.3; cf. 2.55.6 e 6.23.2, onde se lê rumor incedebat; cf. ainda, em 11.32.1, non rumor interea, sed undique nuntii incedunt.

${ }^{33}$ 1.3.4: nam senem Augustum [Liuia] deuinxerat adeo, uti nepotem unicum, Agrippam Postumum, in insulam Planasiam proiecerit.

${ }^{34}$ Talvez a interpretaçáo para electis consciis et comite uno Fabio Maximo seja a de Furneaux 1896 186: "The 'comes' actually attends him, the 'conscii' may only have been aware of the plan.” Cf. Miller 1992 113. Para discussão, v. Goodyear 1972131. 
Neste excerto, a inconfidência (aperuisse) dá lugar à morte (extincto, morte, funere, exitii). $\mathrm{O}$ narrador lança a dúvida sobre se foi suicídio, mas a descrição dos gritos de Márcia no funeral assinala tratar-se de uma morte provocada pelo facto de Fábio saber de mais - e não ter sabido guardar segredo. Acerca da interpretação de quem foi o responsável pela sua morte, levantam-se questóes de transmissão do texto porque o manuscrito está corrompido onde se lê gnarum. A ser correcta esta lição, Fábio morreu porque se sentiu atraiçoado pela mulher depois de ter traído Augusto e de este ter sabido disso. Mas F. Haase (editor da obra completa de Tácito em 1855, Lípsia: Goodyear 197215 e 132) corrige gnarum para ignarum, o que resulta numa interpretação exactamente oposta, pois que sugere que a culpa é de Lívia. Goodyear 1972132 opõe a esta lição o argumento que ignarum id Caesaris "would largely be superfluous". Porém, esta correcção entra em conformidade com a ideia de que a viagem aconteceu contra a vontade e pelo desconhecimento de Lívia e que é ela quem tenta impedir e esconder a reconciliação - e também por isso se apressa a matar o marido. De facto, considero que, se Fábio Máximo se suicidou, terá sido por remorsos — não só por ter traído Augusto, mas principalmente porque quem não devia ter sabido da viagem (Lívia) ficou a saber. Assim, a lição de Haase pode ser considerada reiterativa, não só das artes obscuras de Lívia, mas também do facto de Augusto desconhecer que o seu segredo foi revelado ${ }^{35}$.

Por fim, assinale-se a própria figura de Márcia: como erra inocentemente e como demonstra o arrependimento. É significativo que esta personagem apenas apareça na obra neste pequeno trecho - e mesmo assim seja nomeada duas vezes, como se o narrador náo quisesse que o leitor se esqueça do nome dela - para ilustrar o sofrimento, o que faz dela uma espécie de personagem alegórica. Para usar o termo da tragédia, a hamartia de Márcia é tão inocentemente branda que provoca uma comiseração (eleos) do leitor muito mais pronunciada. Este pequeno apontamento, que constitui uma manifestação da

${ }^{35}$ Se serve de argumento para este ser um passo expressivamente reiterativo, refira-se o pronome eius apenas usado para dar ênfase (Miller 1992 114), a repetição do laço familiar e de quem morreu em exitii marito, e semet, empregue logo a seguir a Marciae. 
tragicidade que caracteriza os Annales, não pode, por isso, ser tido apenas como "a farrago of improbabilities" (Goodyear 1972 131).

A narrativa da cena da morte de Augusto propriamente dita ocupa os dois últimos parágrafos do quinto capítulo:

utcumque se ea res habuit, uixdum ingressus Illyricum Tiberius properis matris litteris accitur; neque satis conpertum est spirantem adhuc Augustum apud urbem Nolam an exanimem reppererit. acribus namque custodiis domum et uias saepserat Liuia, laetique interdum nuntii uulgabantur, donec prouisis quae tempus monebat simul excessisse Augustum et rerum potiri Neronem fama eadem tulit (1.5.3-4).

A fórmula utcumque se ea res habuit rompe com o que foi anteriormente narrado e projecta o texto para o tema que se segue. Estes parágrafos situam-se entre a dúvida (o primeiro) e a certeza (o segundo), opondo-se mutuamente. Quando Tibério, a personagem em que se ajusta o foco narrativo, recebe a carta da máe, parte para Nola, acção descrita pela metonímia reppererit (acontecimento final da viagem). A dúvida consiste em saber se encontrou Augusto spirans ou exanimis. Tanto um como outro vocábulo são metáforas de vida-morte, configuradas numa imagem da respiraçáo, sopro de vida (spirans relaciona-se com spiritus e exanimis com anima: v. Ernout - Meillet 1959 s.v. spiro e anima).

O discurso historiográfico manifesta-se na confissáo neque satis conpertum est, que sugere uma investigação em fontes que não são conclusivas acerca do preciso momento da morte do velho príncipe. Essa falha no conhecimento exacto contrasta com o que se sabe de facto (1.5.4).

Lívia, a única personagem indicada pela relação de parentesco com Tibério, tem o papel mais relevante no último parágrafo. Aí, é ela quem controla visivelmente a situação, não só por ter a casa rodeada de acribus custodiis $^{36}$, mas principalmente por controlar a quantidade de informação divulgada (interdum). Penso que os laeti nuntii servem para alimentar falsas esperanças, ao mesmo tempo que se espera pela chegada de Tibério ${ }^{37}$.

${ }^{36}$ No exílio, Agripa Póstumo também estava à guarda de custodia (1.6.1).

${ }^{37}$ Recordo as mesmas esperanças vãs no caso de Germânico: forte negotiatores uiuente adhuc Germanico Syria egressi laetiora de ualetudine eius attulere. statim credita, statim uulgata sunt (...). cursant per urbem, moliuntur templorum foris; iuuat credulitatem nox et promptior inter tenebras adfirmatio (2.82.4). Depois 
A partir de donec, tudo se precipita em grande velocidade narrativa ao mesmo tempo (simul, eadem). A referência a Tibério como Nero tem vindo a ser interpretada como uma aproximação desta personagem a Lúcio Domício Aenobarbo, o imperador Nero, legitimada por exemplo pela forma semelhante como as mães dos dois actuam para que eles cheguem ao poder. No entanto, observa Miller 1992 114: "Of the nine references to Tiberius as Tiberius Nero or Nero, seven are unexceptionable because they refer to him before his adoption by Augustus". As restantes duas, $1.4 .3 \mathrm{e}$ 1.5.4, continua Miller 1992 115, ocorrem quando "the reference is to $\mathrm{AD} 14$ and the use of the name must be deliberate and malicious - whether on the part of Tacitus, branding Tiberius as by birth no member of the house of Augustus, or on the part of his source, reflecting contemporary gossip and backbiting".

Há ainda que assinalar o uso do verbo excedo, mais uma vez a designar a morte de Augusto, retomando o título. $\mathrm{O}$ seu uso revela que a introdução acabou e que aqui começam os anais $a b$ excessu diui Augusti. 


\section{Eliminação da descendênCia de Augusto}

O maior problema de Augusto na manutenção do poder foi o da sucessão, pois o velho imperador náo teve filhos homens. Este facto impulsionou um movimento de agregação à casa reinante dos seus sobrinhos, sobrinhos-netos, enteados e mesmo do seu amigo de maior confiança, Agripa, por meio da adopçáo. Sujeitos, todavia, a várias circunstâncias, muitos morreram antes do próprio Augusto.

A apresentação dessas personagens no enredo da história faz-se de forma resumida em 1.3.1. Augusto confia-lhes importantes cargos políticos a fim de reforçar a sua autoridade e influência: são os subsidia dominationi. $\mathrm{O}$ termo subsidium remete para um contexto militar, no sentido de 'tropas colocadas de reserva' ${ }^{38}$, donde evolui para 'suporte, ajuda'. Por isso, para Augusto manter a paz precisa de apoio de reserva ${ }^{39}$, visto ter alcançado a paz através do domínio das facçóes inimigas. As personagens que Augusto coloca de reserva săo Marcelo, Agripa, Tibério, Druso, Gaio e Lúcio:

Ceterum Augustus subsidia dominationi Claudium Marcellum sororis filium admodum adulescentem pontificatu et curuli aedilitate, M. Agrippam, ignobilem loco, bonum militia et uictoriae socium, geminatis consulatibus extulit, mox defuncto Marcello generum sumpsit; Tiberium Neronem et Claudium Drusum priuignos imperatoriis nominibus auxit, integra etiam tum domo sua. nam genitos Agrippa Gaium ac Lucium in familiam Caesarum induxerat, necdum posita puerili praetexta principes iunentutis appellari, destinari consules specie recusantisflagrantissime cupiuerat (1.3.1-2).

A escolha dos eleitos resulta de uma grande preocupação com o sangue, como se depreende da abundância de termos do campo lexical da família: sororis filius, gener, prinignus, genitus ${ }^{40}$.

${ }^{38}$ Como surge em 1.63.2 ou 4.73.2.

${ }^{39}$ Ernout - Meillet 1959 s.v. subsidium, OLD s.v. subsidium 4.

${ }^{40}$ É de notar a preocupação do historiador com a origem ignobilis de Agripa. As referências domo sua e in familiam reforçam a isotopia da família, que Santoro L'hoir 2006 15-70 aproxima da tragédia esquiliana. 
Enquanto personagem principal, é Augusto que tem arbítrio sobre o futuro das outras - no caso concreto, sobre as suas carreiras políticas. A variedade de cargos mostra as várias magistraturas e cargos sobre os quais Augusto quer ter influência: pontificatus, curulis aedilitas, consulatus, imperatores, principes iuuentutis, consules. Começa uma alteraçáo ténue do movimento convergente para Augusto na recepção de poder, que passa pela delegação de cargos, ou seja, começa a notar-se uma preocupação com a sucessão dinástica, a que só se fará referência posteriormente.

A notícia da morte da maior parte destas personagens ${ }^{41}$ é dada numa única frase; não sendo apontadas datas, a sequência enumerativa corresponde à seriação cronológica:

ut Agrippa uita concessit, Lucium Caesarem euntem ad Hispaniensis exercitus, Gaium remeantem Armenia et uulnere inualidum mors fato propera uel nouercae Liniae dolus abstulit, Drusoque pridem extincto Nero solus e priuignis erat, illuc cuncta uergere $(1.3 .3)^{42}$.

O primeiro a falecer é Agripa. Trata-se de uma importante personalidade da época, mas, enquanto personagem desta obra, não chega a ser directamente caracterizado, o que contribui para realçar as qualidades militares (enquanto companheiro das vitórias de Augusto e grande general) e políticas (ou não teria cumprido geminati consulatus). No entanto, há que sublinhar a importância da sua prole (também descendentes de Augusto, pelo casamento com Júlia), pois a todos os seus filhos são atribuídos títulos de relevo.

É uma informação quase secundária, expressa em ablativo absoluto, que dá conta da morte de Druso (Drusoque pridem extincto). O díctico pridem remete para um acontecimento passado (analepse), o que cria anacronia na história e contribui para a complexificaçáo da trama, que opera em vários tempos.

Algo diferente acontece com o relato da morte dos irmãos Lúcio e Gaio: é apontada a causa, criando-se uma relaçáo de causa-efeito característica do enredo ${ }^{43}$. Emerge, assim, um

${ }^{41}$ É importante notar desde já a peculiaridade da personagem Marcelo, cuja morte é referida logo no parágrafo anterior, o que propicia o casamento de Júlia com Agripa, união que lhe garantirá vários filhos. Cf. 2.41.3.

${ }^{42}$ Esta frase expressa a queda dos planos dinásticos de Augusto: Goodyear 1972 110. Deve notar-se a concentração de vocábulos ligados à morte (cf. Furneaux 1896 71).

${ }^{43}$ Uso os conceitos de enredo ("plot") e história ("story”) como consignados 
evidente caso de política de bastidores. Recorde-se o passo isoladamente:

Lucium Caesarem euntem ad Hispaniensis exercitus, Gaium remeantem Armenia et uulnere inualidum mors fato propera uel nouercae Liniae dolus abstulit.

Estas mortes, próximas textualmente, ocorrem com diferença cronológica significativa ${ }^{44}$ e são espacialmente muito distantes ${ }^{45}$ : Hispânia e Arménia ${ }^{46}$ (no extremo ocidental e oriental do império, respectivamente). Os verbos que localizam as mortes (eo e remeo) são verbos de movimento e designam movimentos contrários (um vai, o outro regressa). Assim, Lúcio e Gaio não morreram quando estavam na Hispânia e na Arménia, mas enquanto se dirigiam para ou regressavam desses locais. A ideia de movimento (também temporal) é vincada ainda pelos particípios presentes. Trata-se de uma estratégia retórica que confere ao relato maior vivacidade e acção e que, por isso, aproxima as personagens do leitor que visualiza, não uma cena estática, mas in fieri.

Apesar das diferenças assinaladas, a acção é descrita de forma concisa e rápida. $\mathrm{O}$ verbo abstulit também denota movimento, desencadeado por apenas um sujeito, ainda que com dois núcleos separados pela conjunção disjuntiva uel; esta não permite entender qual das hipóteses é a mais provável ou preferida do historiador, pois não enfatiza nenhum dos núcleos nominais ${ }^{47}$. Por um lado, há uma mors apressada pelo destino, necessariamente natural (Goodyear 1972 111), e, por outro, um dolus de uma nova personagem, Lívia, cujo nome próprio é antecedido do grau de parentesco - nouerca, notação de carácter negativo que volta a surgir em 1.6.2, 1.10.5 e 1.33.3. Este vocábulo, do campo lexical

por Forster 192743 e 116. Assim, por história entende-se "a narrative of events arranged in their time sequence"; enredo é "a narrative of events, the emphasis falling on causality."

${ }^{44}$ Lúcio morreu no ano 2 e Gaio em 4.

45 Aliás, os irmãos são, em circunstâncias dinásticas, constantemente referidos em par: aqui, em 1.53.1 e 6.51 .1 (onde se estabelece a relação entre o seu florescimento e a situação de Tibério) e muito significativamente nos seguintes passos, onde surgem referidos pelos plurais indicados: 2.42.3 (Caesarum), 3.6.2 e 12.25.1 (em ambos os casos, nepotibus).

${ }^{46}$ Cf. 2.4.1; 2.42.2; em 3.48.1, diz-se que governa a Arménia.

${ }^{47}$ Assim referem Gerber — Greef — John 1962 s.v. vel. Goodyear 1972 $111 \mathrm{diz}$ que este uso das alternativas é insidioso; as isotopias confirmam-no, mas este passo por si não torna possível chegar a estas conclusóes; cf. 1.10.2. 
da família ${ }^{48}$, completa a ideia iniciada com priuignus em 1.3.1, passo em que se subentendia um outro casamento (Lívia casou com Augusto numa altura em que já tinha nascido Tibério e Druso estava por nascer).

A frase analisada tem três momentos definidos, correspondentes a cada uma das mortes: (1) Agrippa uita concessit, (2) Lucium, Gaium mors/dolus abstulit; (3) Druso pridem extincto. O terceiro momento surge, como referi, em ablativo absoluto, pelo que está em variação com as oraçóes introduzidas por $u t$ temporal ('quando'). Nesta medida, o excerto Druso extincto pode ser entendido como oração subordinada temporal-causal, uma vez que a sequência destes termos constitui também uma causa ${ }^{49}$ : foi depois que eles aconteceram e foi por eles terem acontecido que Tibério ficou sozinho no papel de sucessor (Nero solus $e$ priuignis erat) ${ }^{50}$. Por ser o único, para ele tudo converge (illuc cuncta uergere $\left.^{51}\right)$. O substantivo cuncta é concretizado por meio do processo retórico da tradução (cf. Lausberg 2004 178), ou seja, uma explicitaçáo do sentido para que o leitor possa perceber, no particular, o que significa cuncta, no geral. Assim, Tibério foi adoptado e começou a partilhar poderes com Augusto em magistraturas diferentes:

flius, collega imperii, consors tribuniciae potestatis adsumitur omnisque per exercitus ostentatur, non obscuris, ut antea, matris artibus, sed palam hortatu $(1.3 .3)^{52}$.

${ }^{48}$ Cf. Santoro L'hoir 2006 15-70 para a construção de campos semânticos nos primeiros 10 capítulos do primeiro livro.

${ }^{49}$ Misturam-se os papéis operativos de história e enredo, ao mesmo tempo que se complexifica a narrativa.

${ }^{50}$ Em rigor, Druso também era priuignus de Augusto, mas seria ainda muito novo, tal como o neto Agripa Póstumo - não havendo indicaçóes etárias ou temporais, é difícil saber que idade tinham no tempo da acção. Os outros falecidos eram o gener Agripa e os nepotes Lúcio e Gaio. Percebe-se uma quebra da correspondência entre a causa (as mortes) e o efeito (isolamento de Tibério, sobre o qual recaem todas as coisas) que é difícil explicar.

${ }^{51}$ Mais uma vez, verifica-se o resultado de um efeito e de uma sequência cronológica. O advérbio illuc corresponde a in illum (o verbo uergo é usado figuradamente).

${ }^{52}$ Cum é elemento de formação em collega e consors, de lego e sors. Collega é um termo do direito que significa principalmente 'colega' (numa magistratura); consors 'que partilha, que possui em conjunto' (determinados poderes): cf. Ernout - Meillet 1959 s.v. lex. 
$\mathrm{O}$ verbo adsumo na passiva opera no texto uma mudança de movimento: são poderes atribuídos a Tibério, personagem sem papel activo na sua obtençáo, contrastando fortemente com aquele de Augusto na concentração dos poderes do Estado (por exemplo, recordem-se os anteriores accepit, ferens, pellexit, extulit). O movimento de recepçáo continua com ostentatur, cujo termo circunstancial de lugar (per exercitus) é completado por uma correctio (non... sed) que contrasta o passado com o presente: non obscuris, ut antea, matris artibus, sed palam hortatu. Subentende-se que a história de Tibério foi, até aqui, pouco expressiva, manifestandose o fim de um passado em que a personagem é protegida pelas artes da mãe $e^{53}$ : agora ele é exibido sem reservas a todos os exércitos. Mais significativamente, obscuris, artibus e o anterior dolus formam uma isotopia relacionada com acçóes escondidas que enformam modos de obtenção de poder.

Outra personagem de relevo na descendência de Augusto é, como se viu, Agripa Póstumo. Nascido Marco Vipsânio Agripa Póstumo em 12 a.C., já depois da morte do pai, Marco Vipsânio Agripa, é o terceiro filho varão do casamento deste com Júlia. Com a adopção por Augusto no ano 4 (data da adopção de Tibério), toma o nome de Agripa Júlio César. Nos Annales é (sempre) referido pelo nome de nascimento - estratégia que poderá estar relacionada com o facto de ter sido repudiado e deserdado por Augusto, o que ocorre no ano 6, ao que se seguiu a confiscação de bens e exílio em Surrento, de onde, em 7, é remetido para a ilha de Planásia pelo senado.

Ainda que apareça poucas vezes e em breves trechos ${ }^{54}$, esta personagem é a vítima mais evidente dos ódios da nouerca Lívia. A primeira referência na história acontece em 1.3.4:nam senem Augustum deuinxerat adeo, uti nepotem unicum, Agrippam Postumum, in insulam Planasiam proiecerit. É nítida a presença de uma explicação (nam tem esse valor) da influência que Lívia exerce sobre Augusto, caracterizado como senex ${ }^{55}$. A força manipuladora de Lívia é tal que (adeo uti) Augusto renega alguém do seu próprio sangue. $\mathrm{O}$ verbo que exprime essa violenta influência é deuincio, que em Tácito surge unicamente nos Annales e em sentido

53 Os vocábulos filius e matris retomam a atrás referida isotopia da família.

${ }^{54}$ Agripa Póstumo é referido em oito passos do que nos resta dos Annales: Fabia 1964 s.v. Agrippa Postumus.

${ }^{55}$ A condição de velho (e doente) torna-se um tópico nos Annales, como se estudou na secção anterior. 
figurado ${ }^{56}$. A posição de Agrippam Postumum como aposto a nepotem unicum realça a condição de ser o único descendente de sangue $^{57}$ - e também o único em condiçóes genéticas para lhe suceder no cargo de princeps. A expressão in insulam Planasiam proiecerit denota igualmente violência, pelo movimento que sugere: in regendo acusativo como complemento de proiecerit, verbo aqui usado em sentido figurado, exprimindo exílio.

No mesmo passo, Agripa Póstumo é caracterizado: rudem sane bonarum artium et robore corporis stolide ferocem, nullius tamen flagitii conpertum (1.3.3). Cruzam-se assimetricamente as propriedades psíquicas e físicas representadas por artes e por corpus: é rudis e ferox. Reconhece-se que Agripa tem um carácter desajeitado ou bisonho (rudis bonarum artium ${ }^{58}$ ) — propriedade confirmada com o advérbio sane. Stolide, de uso adverbial e referido a pessoas, aparece (em toda a obra de Tácito: Gerber Greef - John 1962 s.v. stolidus) apenas aqui, onde adquire o valor semântico de 'estupidamente' — tal singularidade individualiza e realça esta característica do corpo de Agripa Póstumo. Por outro lado, robore corporis contrasta com a fragilidade do corpo de Augusto em 1.4.2 — que, por seu lado, Goodyear 1972119 aproxima da expressáo da doença de Germânico no leito de morte (em 2.75.1), criando-se o efeito de aproximação das causas das suas mortes (assassínios). Não sendo apontada qualquer qualidade à personalidade de Agripa, também não tem defeitos morais: nullius flagitii conpertum.

Quando, em 1.4.2, se volta a referir Agripa Póstumo, é o facto de ele ser candidato à sucessão de um Augusto bastante idoso e já doente (postquam prouecta iam senectus aegro et corpore fatigabatur) que se realça: aderatque finis et spes nouae. É em face do destino de Augusto que as pessoas adoptam diferentes atitudes: pauci bona libertatis in cassum disserere ${ }^{59}$, plures bellum

56 Tem o sentido de 'trazer sob o jugo, subjugar': OLD s.v. deuincio 2; Gerber — Greef — John 1962 s.v. deuincio.

57 Vnicus provém de unus (Ernout - Meillet 1959 s.v. unus). É de notar a singularidade, tanto de Agripa Póstumo, como de Tibério (cf. Nero solus e priuignis erat, em 1.3.3).

${ }^{58}$ Construído com genitivo: cf. Gerber - Greef - John 1962 s.v. rudis, onde se apontam os significados de 'inexperiente, bisonho, desajeitado'.

${ }^{59}$ A morte de Augusto representava, pois, novas esperanças e havia quem pensasse na liberdade. $\mathrm{O}$ narrador reflecte assim o descontentamento de uma franja da sociedade que desejava ainda o regresso à república, activando-se a isotopia da esperança que se revelará vã. 
pauescere, alii cupere. No entanto, havia uma maioria destacada (pars multo maxima) que se entretinha a levantar rumores acerca dos sucessores (inminentis dominos uariis rumoribus differebant) do velho princeps (1.4.2). Esta estratégia de exposição de diversas opinióes é definida por Goodyear 1972119 como "a means to put forward views for which a writer does not wish to take direct responsibility." Todavia, a meu ver, é mais importante a perspectiva de alargamento da voz discursiva e da manifestação do grau de conhecimento do narrador, que mostra várias maneiras de pensar de diversas facçóes populares. A expressão de psicologia colectiva surge, pois, em gradação (pauci, plures, alii), assemelhando-se a uma espécie de sondagem de opiniáo pública ${ }^{60}$.

De Agripa Póstumo, esses rumores diziam: trucem Agrippam et ignominia accensum non aetate neque rerum experientia tantae moli parem $(1.4 .3)^{61}$. Em contrapartida, Tibério, educado na casa reinante, tinha ele próprio alguns vícios (que os boatos espalhavam), mas a este passo voltarei depois.

A. J. Woodman 1998 23-39 considera que existe anacronia em alguns capítulos do início do primeiro livro dos Annales, tendo em conta principalmente o facto de o capítulo 6 começar como se já se estivesse no principado de Tibério e no sétimo ainda estarem por decidir os cargos públicos que caberão ao imperador. Recordem-se as palavras do texto:

Primum facinus noui principatus fuit Postumi Agrippae caedes, quem ignarum inermumque quamuis firmatus animo centurio aegre confecit (1.6.1).

Da primeira oração decorrem algumas ideias fundamentais: primum indicia que, sendo o primeiro, haverá outros; noui principatus sugere que esta forma de organização do governo está consolidada e vai continuar — sem indicar, necessariamente, continuidade das políticas (na linguagem política, o verbo que deriva de nouus, nouo, pode significar 'mudar de regime' ${ }^{\prime 2}$ ).

${ }^{60}$ Ainda assim, Goodyear 1972120 reconhece que "in this instance, the state of opinion (...) is of exceptional interest."

${ }^{61}$ Goodyear 1972120 e Miller 199217.

${ }^{62}$ Cf. Ernout - Meillet 1959 s.v. nouus. Este passo repercute-se no início do livro XIII: prima nouo principatu mors Iunii Silani, referindo-se ao principado de Nero. Goodyear 1972 133-134, citando R. Martin, distingue os dois trechos: "the genitive noui principatus firmly and immediately imputes responsibility for the facinus, and further the whole phrase shows once again 
A inversão do nome Postumi Agrippae não é rara nos Annales: $1.53 .2,2.39 .1$ e 3.30 .3 sáo os outros momentos em que a personagem é referida com o nome invertido ${ }^{63}$. A explicaçáo para esta anástrofe pode residir na busca de uariatio. A oração relativa que completa a frase mostra de forma lacónica a circunstância em que se deu tal acto: quem [sc. Agrippam] ignarum inermumque quamuis firmatus animo centurio aegre confecit. A inexperiência de Agripa notou-se até ao dia da sua morte, uma vez que ele não se apercebeu de que o fim estava próximo (ignarum).

A informação é pouca e narrada num tom rápido, tornando lícito ao leitor inquirir sobre a dificuldade em matar um homem desarmado (inermum) e apanhado de surpresa. Deve, por isso, recordar-se a constituição física da vítima (robore corporis stolide, 1.3.4) e subentender uma luta aguerrida. No entanto, como a frase seguinte desvia o foco temático para Tibério, o leitor percebe que náo tem de esperar acção fora da esfera política - e que a omissão de mais pormenores na narrativa é intencional.

É, pois, a reacção de Tibério que é descrita depois de contada a morte de Agripa:

nibil de ea re Tiberius apud senatum disseruit: patris iussa simulabat, quibus praescripsisset tribuno custodiae adposito ne cunctaretur Agrippam morte adficere quandoque ipse supremum diem expleuisset (1.6.1).

O emprego do verbo declarativo dissero chama a atenção para a sua carga semântica, sendo manifesto o apelo à interioridade da personagem, que náo revela os seus sentimentos. A alusão breve e subtil à hipocrisia e dissimulação de Tibério toma consistência na fórmula patris iussa simulabat. Trata-se evidentemente de uma contradição, pois simulabatintroduz não só a ideia de dissimulação, mas também um discurso - afinal, Tibério disse alguma coisa sobre o assunto; desculpou-se com ordens de Augusto, quibus praescripsisset tribuno custodiae adposito ne cunctaretur Agrippam morte adficere. A acção de escrita foi feita com antecedência (noção dada pelo prefixo prae- e pelo tempo verbal de praescribo, 'escrever antes') e a ordem era para ser executada sem demora, como se depreende da lítotes ne cunctaretur. No segmento tribuno

that T[acitus] rejects the relevance of constitutional formalities: it reiterates what has been stated at the end of chapter 5". Cf. Woodman 1998 26-27.

${ }^{63}$ Que, aliás, só aparece na ordem normal em 1.3.4. 
custodiae adposito é necessário subentender informação, pois quem mata Agripa é um centurião e não o tribuno. A expressão temporal quandoque ipse [sc. Augustus] supremum diem expleuisset cria anacronia na narrativa, uma vez que, nos Annales, a morte de Augusto não implicou o início do principado de Tibério no mesmo instante. Tal anacronia complexifica a narrativa, pela sobreposição de campos temporais que dela decorre.

A defesa de Augusto é feita pela voz do narrador:

multa sine dubio saeuaque Augustus de moribus adulescentis questus, ut exilium eius senatus consulto sanciretur perfecerat: ceterum in nullius umquam suorum necem durauit, neque mortem nepoti pro securitate priuigni inlatam credibile erat. propius uero Tiberium ac Liuiam, illum metu, hanc nouercalibus odiis, suspecti et inuisi iuunenis caedem festinauisse (1.6.2).

A expressão sine dubio alega o elevado grau de conhecimento do narrador, que afiança a verdade das suas informaçóes. $\mathrm{O}$ segmento multa saeuaque de moribus questus aproxima Augusto de Tibério em 1.4.3 ${ }^{64}$ : Tiberium Neronem (...) multaque indicia saeuitiae (...) erumpere er $^{65}$.

Imputando estas ideias ao povo, pelos rumores, e a Augusto - ainda que sob o escopo da expressão credibile erat, que indica tratar-se do pensamento da época (Goodyear 1972 135) —, o narrador faz-nos acreditar que o princeps não teve nada que ver com o assassínio de Agripa, até porque neque mortem nepoti pro securitate priuigni inlatam credibile erat ${ }^{66}$.

${ }^{64}$ Esta lamentação repete o rumor do povo que o narrador descrevia em 1.4.3, sobre Tibério.

${ }^{65}$ Concordante com esta relação, e ainda que as diferenças sejam evidentes por não haver notícia de saeuitia ser característica da psicologia de Augusto, estáo as palavras do povo expressas em 1.10.7 (sublinhados meus): ne Tiberium quidem caritate aut rei publicae cura successorem adscitum, sed quoniam adrogantiam saeuitiamque eius introspexerit, comparatione deterrima sibi gloriam quaesiuisse. etenim Augustus paucis ante annis, cum Tiberio tribuniciam potestatem a patribus rursum postularet, quamquam honora oratione quaedam de habitu cultuque et institutis eius iecerat quae uelut excusando exprobraret.

${ }^{66}$ A frase não tem verbo principal, pelo que surge em zeugma com a expressão credibile erat. Woodman 1998 28-32 estuda as alternativas erat e est, e conclui que a forma correcta deveria ser credibile esse, por ser discurso indirecto dependente de um verbo dicendi subentendido. Assim, esta frase decorre do que se pensava na época e não reflecte a opinião do narrador acerca da morte de Agripa Póstumo. 
No entanto, se Agripa era cruel, Tibério também era, ainda que o tentasse esconder: Tiberium Neronem maturum annis, spectatum bello, sed uetere atque insita Claudiae familiae superbia, multaque indicia saeuitiae, quamquam premantur, erumpere (1.4.3). São evidentes as qualidades de Tibério Nero: maturum annis, spectatum bello - particípios acompanhados de ablativos (construção em paralelo), que é uma estrutura que se estende até insita superbia, onde o ablativo adquire o aspecto de ablativo de qualidade, enquanto os outros se definem como ablativos de relação (armis) e instrumental (bello), como classifica Miller 1992 111.

A conjunção sed altera a polaridade do discurso, que passa a negativa, pois agora fala-se dos defeitos: superbia (definida como uetus atque insita, por isso totalmente genética) e os já referidos multa indicia saeuitiae. Se Tibério foi educado na casa reinante desde criança, cumpriu consulados e triunfos ainda jovem, tendo podido adquirir a experiência e mores de governação, bem diferente de Agripa Póstumo ${ }^{67}$ :

hunc et prima ab infantia eductum in domo regnatrice; congestos iuuneni consulatus, triumphos (1.4.3).

No entanto, se até aqui se pode entender estas características como fundamentais para a eleição do novo princeps, a conjunção ne volta a alterar a polaridade da frase e da sua significaçáo: ne iis quidem annis quibus Rhodi specie secessus exul68 egerit aliud quam iram et simulationem et secretas libidines meditatum (1.4.4). O discurso transmite o lado negativo, caracterizado pelo vocabulário ligado à simulação (isotopia que caracteriza Tibério) — specie, simulationem - , a que se acrescentam secretas libidines. $\mathrm{O}$ particípio meditatum penetra no interior da personagem e reflecte a profundidade da concepçáo literária de Tibério. É ainda concretizada a ideia de que Tibério foi um exilado (specie secessus exul egerit), condição que partilha com Agripa Póstumo. No entanto, os exílios são manifestamente distintos. Tibério auto-exilou-se, numa acção simulada (Goodyear 1972 122123), ao passo que Agripa foi obrigado (proiecerit, em 1.3.4, tem essa força).

${ }^{67}$ Lembre-se neque rerum experientia tantae moli parem (1.4.3).

${ }^{68} \mathrm{O}$ manuscrito escreve exulem, para o que v. Goodyear 1972122. 


\section{GERMÂNICO}

A figura de Germânico, que domina a primeira parte da narrativa do principado de Tibério, é uma das personagens mais complexas dos Annales. A análise literária que agora proponho - e que segue a teoria de E. M. Forster, segundo a qual tudo o que podemos saber e tudo o que precisamos saber acerca de uma personagem literária advém da informação dada pelo seu autor $^{69}$ — visa aprofundar a questão colocada por L. W. Rutland nestes termos: "A detailed study of the Tacitean Germanicus may yet decide for the naive and innocent youth or for the clever and dangerous image-maker."70

No caso de Germânico, deverão distinguir-se três tipos de caracterização: (1) uma directa, a que se tem acesso pelo que o narrador afirma, (2) outra, a que chamarei oblíqua, que é aquela que concorre para a caracterização da personagem a partir do que sustentam os rumores e o que pensam as outras personagens ${ }^{71}$, e finalmente (3) uma indirecta, possível pelo que os actos e comportamentos narrados denunciam. É a estes tipos de análise que a caracterização que a seguir se apresenta presta atenção.

Goodyear 197233 avalia o papel de Germânico nos Annales como o herói criado pelo narrador em oposição a Tibério: "From

${ }^{69}$ Esta ideia surge em Forster 1927 68. O autor distingue as personagens criadas no romance e as que existem em obras historiográficas: "The historian deals with actions, and with the characters of men only so far as he can deduce them from their actions. He is quite as much concerned with character as the novelist, but he can only know of its experience when it shows on the surface." (Forster 1927 65). E se é certo que a função do romancista é revelar o que se encontra escondido, de modo a tornar uma personagem de ficção, e não recriar uma entidade histórica (Forster dá o exemplo do que pode ocorrer com uma figura histórica como a rainha Vitória), pode igualmente deduzirse que Germânico ou Tibério são, em grande parte (tal como os crít+icos os têm analisado), recriaçóes ficcionais das personagens históricas, e não as personalidades históricas.

70 Rutland 1987 164. Este artigo faz um levantamento das principais questóes que se colocam a quem estuda esta personagem, sublinhando argumentos de vários autores que já se dedicaram ao tema.

${ }^{71}$ A teoria da literatura inclui esta caracterização no tipo directo, mas nesta obra é importante distinguir a origem da informação (narrador/rumores) por esta ser diversas vezes discordante. 
a stylistic point of view it is an immense advantage for $\mathrm{T}$ [acitus] to be able to set Germanicus in contrast with Tiberius, for this contrast is a very effective form of indirect characterization and contributes much to T[acitus]' denigration of Tiberius as a man and as a princeps." Esse contraste tem levado alguns académicos a extremos algo imprudentes; por exemplo, S. G. Daitz faz uma caracterizaçáo de tal modo distante do sentido do texto que das suas palavras se conclui que Tibério representa todo o mal, enquanto Germânico emana gentileza e bondade, sem defeitos (Daitz 1960). D. O. Ross apresenta uma perspectiva contrária, pois considera Germânico "a figure of failure and futility" (Ross 1973). Acontece, porém, que Germânico (tal como Tibério) é uma personagem grandemente matizada e de modo algum pode considerar-se uma personagem plana, muito pelo contrário ${ }^{72}$.

Do meu ponto de vista, Germânico sofre transformaçóes psicológicas que se manifestam nas suas acçôes. Assim, entendo que ele é, no início, um jovem general que, apesar de imaturo ${ }^{73}$ e ingénuo, é promissor, ainda que enfrente reveses significativos (como o naufrágio). Afirma-se desde cedo que ele não desconhece os odia secretos (do tio e da avó, mas também de Pisão) de que é alvo. São, aliás, esses odia que, hiperbolizados pelos seus companheiros (e afirmados pela opiniâo pública da época ${ }^{74}$, transformam Germânico numa personagem menos tolerante, desconfiada, mas sobretudo vingativa ${ }^{75}$.

Ele sofre a injustiça da hostilidade aparentemente sem motivo do imperador (de que tem plena consciência) com uma tolerância quase intocável. No entanto, ainda segundo Goodyear, Germânico não constitui inteiramente a imagem de herói com integridade moral cujo objectivo é salvar o povo da opressão de um Tibério tirano, taciturno e hipócrita, que sustenta a governação

${ }^{72}$ Os conceitos de personagem plana ou personagem redonda são de Forster 1927 93-106. O autor sugere um teste para verificação da profundidade das personagens: "The test of a round character is whether it is capable of surprising in a convincing way. If it never surprises, it is flat. If it does not convince, it is a flat pretending to be round." (Forster 1927 106).

${ }^{73}$ A referência à sua imaturidade sai da boca de Armínio (1.59.5: inperitum adulescentulum), mas como se verá, são as suas acçóes que denunciam essa característica.

${ }^{74}$ Cf. 1.33.1. O odium de Tibério e de Augusta aproxima Germânico de Agripa Póstumo (1.6.2), evidenciando o elemento trágico que será a sua morte.

${ }^{75}$ Ainda de acordo com o teste de Forster, Germânico acaba, assim, por surpreender. 
no medo e na artificialidade ou ambiguidade dos seus actos. Com efeito, penso que Germânico pode ser entendido como uma das personagens em que a isotopia aparência-realidade está mais activa. Tal como Goodyear, considero que, por mais que o narrador tenha realçado a polaridade positiva de Germânico, ele tem uma coloração muito especial e complexa. Por isso, o estudo tradicional da caracterização e construção desta personagem enquanto herói trágico necessita de uma perspectiva mais completa.

Com efeito, Germânico é comummente apreciado enquanto herói trágico. Existem, de facto, elementos que facilmente são identificáveis com as características de uma tal concepção. Por exemplo, Santoro L'hoir realça o conhecimento como um elemento fundamental para a tragédia, aplicado a Germânico (e a Cláudio): "Knowledge in tragedy was connected with personal insight, and Tacitus seems to associate the two attributes in his portrayals of Germanicus and Claudius, in which both are linked with clusters of words connoting knowledge and inner vision." A mesma autora entende que "[b] oth men, however display no inner vision; they are clueless about the reality of their surroundings and circumstances" (Santoro L'hoir 2006 92). Não penso que assim seja, pois, em relação a Germânico, expressóes como nota haec Germanico (2.55.2, referindo-se às contumélias de Pisão e Plancina de que era vítima) anulam esta conclusão ${ }^{76}$. Aliás, é o desejo de saber que torna Germânico naquilo que ele é, enquanto general $(1.51 .2,2.12 .1,2.43 .1,2.64 .1)$ e enquanto personalidade de curiosidade incansável $(2.54 .2,2.59)^{77}$. Do mesmo modo, não é verdade que a Germânico falte visão interior. Passos em que a narrativa ajusta o foco em Germânico demonstram nitidamente os seus dilemas e anseios. Encontram-se exemplos significativos disso no momento em que ele pensa que falhou como líder por ocasião dos motins (focalização interna em 1.40.1-2), ou quando atribui a Pisão e Plancina a causa da sua morte (discurso directo em 2.71.1).

${ }^{76}$ Outros exemplos: 2.55.3, 2.55.6, 2.57.4, 2.69.1.

77 Apenas em 2.60.1, enquanto viaja pelo Egipto, Germânico age por desconhecimento das censuras que Tibério lhe dirige. Ainda assim, Santoro L'hoir 2006, talvez pelo âmbito da sua obra, que demonstra exemplarmente como os Annales aliam a historiografia à retórica e à tragédia, interpreta essas ilustraçóes de poder de conhecimento como ambíguos (porque surgem algumas vezes com correspondentes antonímicos) e exemplos de como a personagem é caracterizada como inconstante. 
Por seu lado, B. Walker considera que a atmosfera exótica que se cria em torno de Germânico contribui para um aumento do pathos (Walker 1952 120-121), para o que concorrem igualmente a suposta culpa de Tibério e a reacção do público à morte da personagem. A dramatização de algumas cenas, como a imagem da multidão que acompanha Agripina na sua viagem para Roma, transportando as cinzas do marido, é identificada por esta autora como um coro grego (Walker 1952123 e 125).

Apesar destas asserçóes, muitos comportamentos de Germânico apresentam-se incompatíveis com uma concepção de personagem trágica. Nesse sentido, o discurso rancoroso que teve no leito de morte, pedindo vingança (e não justiça, por exemplo), coloca-o numa situação de inversão de papéis vítima-criminoso ${ }^{78}$.

B. Walker comenta que alguns episódios em que Germânico se vê envolvido espelham uma natureza romântica "in the evocation of an exotic and barbarous background and the idealisation of the hero" (Walker 1952 118). Esses episódios são extensos e coincidem, para Walker, com a actuação de Germânico junto dos soldados revoltados, com as campanhas militares do livro I, e com as últimas expediçóes militares que realiza no livro II. Em outros episódios, Germânico surge como um apreciador do exótico, como o seu comportamento denuncia, principalmente depois de abandonar a Germânia ${ }^{79}$. Há ainda os momentos em que desrespeita a lei (no enterro dos restos mortais dos soldados mortos em Teutoburgo ${ }^{80}$, ou na citada visita ao Egipto, em 1.62.1 e 2.59.3) e em que retarda o cumprimento de ordens superiores (parecendo que as cumpre contrariado, sendo a viagem até à Síria exemplar também sob este aspecto).

Na análise que agora proponho pretende-se realçar o progressivo aumento da tensão dramática que culminará na morte de Germânico, confirmando-se certa disfunção e fracasso enquanto personagem em cujas qualidades eram postas as esperanças do povo.

${ }^{78}$ Desenvolverei este tópico ao tratar a morte de Pisão.

${ }^{79} \mathrm{O}$ luxo de que é acusado por Pisão, que critica os seus comportamentos durante o banquete do rei dos Nabateus, é disso exemplo, assim como os passeios na viagem para a Síria (2.53.1-55.5) e no Egipto.

${ }^{80}$ Neste episódio, Germânico acaba por ser censurado por Tibério (1.60.2). $\mathrm{O}$ facto de, em 2.7.3, ele já não querer reconstruir o túmulo pode ter que ver com o reconhecimento da validade dos argumentos de Tibério. 


\subsection{O HERÓI DA GERMÂNIA}

Apesar de a narrativa dos Annales remeter muitas vezes para uma imagem pública de Germânico ${ }^{81}$ com características militares positivas, o certo é que, tal como Goodyear 2004258 revela, ele surge como um general medíocre. De facto, diz Goodyear 2004 240:

Tiberius' distrust of Germanicus was neither unintelligible nor unreasonable, and Tiberius' doubts over the real value of Germanicus' campaign were justified. Further, Germanicus' impulsiveness, ineffectiveness, and sheer incompetence, in face of the mutiny and otherwise, are unequivocally and abundantly revealed in T[acitus]' narrative (...). Finally, T[acitus] gives at least indirect expression of unfavourable interpretations of Germanicus' conduct, which we may, if we will, accept as valid.

A morte de Augusto foi pretexto para que as três legióes da Panónia e quatro das oito da Germânia se revoltassem ${ }^{82}$, porque os soldados viam na mudança de princeps uma oportunidade para reivindicarem melhores condiçóes de serviço, reformas e dispensas

${ }^{81}$ Germânico nasceu a 24 de Maio de 15 a.C. com o nome de Nero Cláudio Druso, passando a chamar-se Nero Cláudio Germânico depois da morte do pai, e Germânico Júlio César depois da adopção por Tibério.

${ }^{82}$ Para controlar a revolta dos soldados da Panónia, Tibério envia o filho Druso (1.16.1-30.5). Os dois episódios apresentam paralelos flagrantes, objecto de análise em Woodman 2006a: no início de cada motim, as legiốes encontram-se nos acampamentos de Verão, a desempenhar tarefas atípicas; referem-se as causas que desencadeiam as revoltas e o que daí esperavam os soldados. As tropas queixam-se dos anos de serviço, das despesas das remissóes, das feridas e golpes que receberam; pedem remédios e dispensa imediata. A crueldade dos centurióes (entretanto perseguidos e atacados) é outro motivo de queixa. Nas duas narrativas, as tropas despem-se para mostrar as condiçôes físicas, o prefeito do campo é atacado, é um filho do imperador que chega para pôr termo à situação, mas verifica-se um recrudescimento do tumulto, no qual uma carta do imperador tem papel crucial. Alguém se oferece para morrer nas duas circunstâncias, na multidão há contrastes de silêncio-clamor, o elemento da família imperial é cercado, há alguém atirado do palanque, "in each, the troops are made to reflect on the concessions which they have extorted by force: in Pannonia, this is a source of satisfaction to them (...); in Germany, of guilt", há súplicas feitas aos pés de alguém, "and a legatus who is the subject of a counterfactual statement” (Woodman 2006a 306), há um debate em como se deve resolver a situação e referência à severidade das medidas tomadas. Há um elemento de peripateia (o eclipse na Panónia e a partida de Agripina e Calígula). "Each mutiny concludes with the troops seeing their circumstances in terms of impiety and atonement" (Woodman 2006a 307). 
mais cedo, e protestarem contra o tratamento de que eram vítimas pelos seus superiores $(1.17 .1-6,31.1,31.4,35.1-5)$. Destes motins, o mais violento e aquele que constitui o episódio mais extenso e complexo é o das legióes da Germânia, de que Germânico era o chefe militar ${ }^{83}$ (cargo atribuído por Augusto, 1.3.5). O início da revolta encontra Germânico na Gália, responsável pelo censo ${ }^{84}$, o qual, ao tomar conhecimento do sucedido, parte rapidamente para junto das suas legióes e confronta os soldados (que baixam a cabeça em sinal de paenitentia) fora do acampamento (1.34.1). Só quando Germânico entra no acampamento começam as queixas (questus). Após a descrição de uma cena cheia de patético, em que os soldados mostram os seus corpos feridos e defeituosos (1.34.2), e depois de Germânico ordenar que se organizem em manípulos (em 1.34.3, cena que indicia a debilidade da autoridade do general, acentuada posteriormente), começa a discursar:

tunc a ueneratione Augusti orsus flexit ad uictorias triumphosque Tiberii, praecipuis laudibus celebrans quae apud Germanias illis cum legionibus pulcherrima fecisset. Italiae inde consensum, Galliarum fidem extollit; nil usquam turbidum aut discors. silentio haec uel murmure modico audita sunt (1.34.4).

Este breve discurso (em oratio obliqua) apela à memória dos soldados, exaltando vitórias e triunfos de Tibério. Trata-se de uma manifestação de pietas (cf. 1.42.3-4), pela invocação do nome de Augusto (o modelo político e moral, religioso e militar, cuja memória justifica muitas tomadas de decisáo e restringe outras ${ }^{85}$ ). Assiste-se a um movimento linear, veiculado pela própria construção sintáctica ${ }^{86}$, de pormenorização do discurso, que parte do geral para o particular, de situaçóes distantes para as que os

${ }^{83}$ Germânico tem a seu cargo dois exércitos, o superior (constituído pelas legiôes II, XIII, XIV e XVI, comandado por Gaio Sílio) e o inferior (com as legióes I, V, XX e XXI, comandado por Aulo Cecina). Foi no exército inferior que começou a revolta (1.31.2).

${ }^{84}$ A repetição dessa informação $(1.31 .2,33.1)$ parece sugerir uma desresponsabilização de Germânico no que respeita ao início do motim (ao contrário do que acontece com Aulo Cecina, visto que este tinha deixado as legióes em inactividade ou com poucas responsabilidades, 1.31.3).

${ }^{85}$ Algumas decisóes de Tibério em que se mostra essa reverência: 1.14.4, 1.77.3, ou 2.59.2.

${ }^{86}$ Sequencialidade directa, complementos (de lugar donde/origem e para onde/destino) ligados por um único verbo (flexit). 
destinatários conhecem por nelas terem participado com Tibério, o actual princeps. A familiarização de acontecimentos (que serve de captatio beneuolentiae) será, mais à frente, argumento para mudanças de atitude, o que não acontece aqui.

A recepção das palavras de Germânico continua a atitude de desafio que os soldados haviam já adoptado (como se viu na recusa de formação à chegada de Germânico, em 1.34.3). Quando o general pergunta onde estava o respeito militar (modestia militaris), a dignidade da velha disciplina (ueteris disciplinae decus), os tribunos e os centurióes (que surgem como símbolo da hierarquia e respeito), a resposta surge em linguagem corporal e não verbal: nudant uniuersi corpora, cicatrices ex uulneribus, uerberum notas exprobrant (1.35.1). Este é mais um elemento que contribui para a imagem do exército enquanto sujeito aos rigores de uma disciplina que os soldados achavam injusta (cf. 1.34.2). Começa, igualmente, a notar-se um adensar da tensão entre a chefia e a soldadesca, que volta às reivindicaçóes. $\mathrm{O}$ discurso indirecto, representativo da fala colectiva (indiscretis uocibus), culmina com palavras auspiciosas em relação a Germânico, a quem - retomando-se um dos motivos que originaram o motim — é oferecido o poder: faustis in Germanicum ominibus; et si uellet imperium promptos ostentauere (1.35.3).

A reacção de Germânico surge assim descrita:

tum uero, quasi scelere contaminaretur, praeceps tribunali desiluit. opposuerunt abeunti arma, minitantes, ni regrederetur; at ille moriturum potius quam fidem exueret clamitans, ferrum a latere diripuit elatumque deferebat in pectus, ni proximi prensam dextram ui attinuissent (1.35.3).

É uma cena cheia de movimento, demonstrativa da faceta mais impulsiva de Germânico. Na primeira frase transcrita, uma pequena oração revela quase discretamente a profundidade psicológica de Germânico, encerrando nela um exercício de reflexão. O salto de cima da tribuna representa a rejeição da ignomínia que seria reivindicar o poder absoluto, ao mesmo tempo que indicia o facto de não vir a responder à spes dos soldados e do povo (cf. principalmente 1.31.1: magna spe fore ut Germanicus Caesar imperium alterius pati nequiret). A segunda frase, de apenas seis palavras (quatro verbos, dois conjugados e dois no particípio presente), contribui para a descrição de uma cena rápida e de movimentos simultâneos. 
O único substantivo é arma, que sublinha a violência da cena.

Nestas circunstâncias, Germânico coloca as alternativas lado a lado. Identificando a oferta do exército com uma renúncia à palavra dada, fides, prefere a morte. A expressão de preferência é uma oração comparativa com potius quam. O verbo que introduz a oratio obliqua com que o discurso é feito está no particípio presente, clamitans, pelo que denota um aspecto frequentativo e a simultaneidade de acção. Com efeito, enquanto diz isto, Germânico desembainha a espada e prepara-se para enterrá-la no peito; não fosse a rápida actuação dos amigos que lhe estavam próximos, Germânico ter-se-ia suicidado. A patética tentativa de suicídio indicia uma forma de manipulaçáo da opiniáo dos soldados, simulando ou denotando o desespero, por parte da personagem (em 2.24.2, Germânico volta a tentar o suicídio, por outros motivos).

Este quadro é desde sempre acompanhado pela descrição do comportamento colectivo dos soldados. Havia prova disso nos discursos que eram proferidos como colectivos e na maneira como são introduzidos na sequência narrativa: em oratio obliqua, construçóes impessoais (fuere qui, 1.35.3) ou com sujeitos do tipo pars contionis e singuli (1.35.5), compreendendo conjunto. Neste discurso indirecto exprime-se assim a voz que representa o sentimento dominante no exército e o autor textual assume o conhecimento universal do interior das suas personagens, de que decorre uma imagem consistente da personagem colectiva que são os exércitos.

Como alguns soldados pretendem que Germânico se fira, o próprio narrador se mostra indignado com a atitude tomada, como denuncia a expressão valorativa uix credibile dictu. Acto isolado, há até um deles, Calusídio, que se chegou ao pé de Germânico e lhe ofereceu o seu gládio, sob o pretexto de estar mais afiado. A autoridade de Germânico é indiscutivelmente posta em causa nesta manifestação da ironia de um exército que quis promover o seu general a princeps e que deseja (e pede) agora a sua morte. Germânico foi depois levado para a tenda pelos amigos e a cena termina aqui, mas haverá outras consequências.

Ao decidir sobre o remedium ${ }^{87}$ para resolver o problema de disciplina, com a ameaça de um aumento da violência ${ }^{88}$, com o

${ }^{87} \mathrm{O}$ motim é visto como furor (que também significa 'doença'), pelo que é necessário curá-lo (cf., e.g., 1.44.4, 1.49.2 e 1.49.3). Para esta perspectiva, v. Woodman 2006a.

${ }^{88}$ Com a possibilidade de o motim se alastrar ao exército superior (1.36.1). 
medo de que os inimigos aproveitassem o motim em seu proveito (gnarus Romanae seditionis et ... inuasurus hostis) e da guerra civil (ciuile bellum), Germânico age desesperadamente, no limite da tensão desta revolta: periculosa seueritas, flagitiosa largitio: seu nibil militi siue omnia concederentur ${ }^{89}$ in ancipiti res publica (1.36.2). É forjada uma carta de Tibério, onde este concederia aos soldados as suas principais reivindicações ${ }^{90}$ : igitur uolutatis inter se rationibus placitum ut epistulae nomine principis scriberentur (1.36.3; cf. 1.44.4).

Os soldados, que escapam à ignorância dos soldados da Panónia, enganados a propósito do eclipse, percebem que se trata de uma fabricação: Sensit miles in tempus conficta statimque flagitauit (1.37.1). Esta acção exemplifica de forma bastante evidente em que medida a isotopia aparência-realidade está activa também em relação a Germânico. As concessóes de dispensa e pagamentos acabam, mesmo assim, por ser feitas a uma parte dos soldados ${ }^{91}$.

Um acontecimento acabará por resultar num recrudescimento da violência e no agravamento da situação, agora aparentemente harmoniosa. Trata-se da chegada dos legados do senado (1.39.1, cf. 1.14.3), porque os soldados receiam que as decisóes feitas em seu favor sejam revogadas (1.39.2). Os representantes do poder acabam por ser maltratados pelos militares que, de noite (símbolo da violência cega: Pimentel 2006), tiram Germânico da cama, sob ameaça de morte e exigem que entregue o estandarte:

et nocte concubia uexillum in domo Germanici situm flagitare occipiunt, concursuque ad ianuam facto moliuntur fores, extractum cubili Caesarem tradere uexillum intento mortis metu subigunt (1.39.3).

${ }^{89}$ No manuscrito, concedentur. Sobre as duas liçôes, v. Goodyear 1972 265, que considera que o texto mantém a representação do pensamento das personagens (Germânico e amigos).

${ }^{90}$ É por responder de forma tão directa ao que os soldados pediam que a carta denuncia a incompetência de Germânico em lidar com este caso; Goodyear 1972266.

${ }^{91}$ Às legióes V e XXI. O dinheiro foi dado por Germânico e pelos seus amigos: contracta ex uiatico amicorum ipsiusque Caesaris pecunia persolueretur (1.37.1). Como para as compensar da espera, Cecina comanda as legióes I e XX contra os Úbios. Por seu turno, uma vez junto do exército superior, Germânico concede às legióes II, XIII, e XVI dispensas e dinheiro, sem que elas o tenham reivindicado. 
Esta cena, como demonstraram os comentadores ${ }^{92}$, configura a incapacidade de Germânico de lidar com um sério caso de rebeldia, pois os soldados chegam a perseguir e agredir quase até à morte um dos legados do senado, Munácio Planco ${ }^{93}$.

Numa situação de tão grande medo, todos criticam Germânico por náo se ter socorrido do exército superior, por ter cometido erros ao conceder dispensas e dinheiro, bem como as suas decisóes sem vigor:

Eo in metu arguere Germanicum omnes quod non ad superiorem exercitum pergeret, ubi obsequia et contra rebellis auxilium: satis superque missione et pecunia et mollibus consultis peccatum. uel si uilis ipsi salus ${ }^{94}$, cur filium paruulum, cur grauidam coniugem inter furentis et omnis humani iuris uiolatores haberet? illos saltem auo et rei publicae redderet (1.40.1-2).

Esta é a imagem de total falência de Germânico, com todos a porem em causa as suas decisóes. A incerteza e a crítica de um sujeito colectivo são bem sentidas na repetição de cur, na hipérbole omnis humani iuris uiolatores e na própria interrogação. Trata-se de um efeito retórico que aproxima estas reflexóes daquelas que se encontram num coro trágico. Também Tibério irá criticar o pagamento de dinheiro e a concessão de dispensas (1.52.1), principalmente porque ele próprio atingiu a glória militar na Germânia.

Em absoluto desespero, e depois de muito hesitar, Germânico toma uma decisão que provoca uma tensão patética nos soldados e que resultará na reabilitação da sua imagem — a retirada da família, o filho Gaio, referido como filius paruulus, e da mulher Agripina, grauida coniux, do acampamento:

diu cunctatus aspernantem uxorem, cum se diuo Augusto ortam neque degenerem ad pericula testaretur, postremo uterum eius et communem filium multo cum fletu complexus, ut abiret perpulit (1.40.3).

${ }^{92}$ Goodyear 1972 273-4 resume as interpretaçóes que se têm feito sobre uexillum in domo Germanici situm. Furneaux 1896232 pondera a possibilidade de a expressão poder significar uma "intention to elect a new general, of which there is no evidence".

${ }^{93}$ Nesse aspecto, o contrário de Bleso, líder das legióes da Panónia, como defende Shotter 1968198.

${ }^{4}$ A desvalorização da vida e a preocupação em salvar a mulher, neta de Augusto, e os filhos serão assuntos retomados no discurso às tropas. 
A cena de despedida, em que o general aparece como marido e pai a despedir-se da mulher grávida e do filho, é bastante comovente, como representam elementos como uterus, o símbolo de vida e, juntamente com communis filius, do amor; aliados a este enquadramento familiar, o choro abundante (multo cum fletu) e os abraços configuram o patético da cena.

Semelhante carga emotiva - mas agora focalizada na mulher fugitiva e nos que a viam partir com o filho ao colo, como que por contágio - é verificável no cortejo que se segue à despedida:

incedebat muliebre et miserabile agmen ${ }^{95}$, profuga ducis uxor, paruulum sinu filium gerens, lamentantes circum amicorum coniuges quae simul trahebantur nec minus tristes qui manebant (1.40.4).

O acampamento, naquele ambiente de desolação, é comparado a uma cidade vencida:

Non florentis Caesaris neque suis in castris, sed uelut in urbe uicta facies gemitusque ac planctus etiam militum auris oraque aduertere: progrediuntur contuberniis. quis ille flebilis sonus? quod tam triste $e^{96}$ ? feminas inlustris, non centurionem ad tutelam, non militem, nibil imperatoriae uxoris aut comitatus soliti (1.41.1).

Toda esta emoção tem representação no vocabulário que revela bem a tristeza da cena: miserabile, lamentantes, tristes, non florentis, urbe uicta, gemitus, planctus, flebilis sonus, triste. O choro e a lamentação acabam por chamar a atenção dos soldados, que, à medida que vão tomando conhecimento do que estava para acontecer, emergem das tendas, numa grande agitação. As rápidas movimentaçóes dos militares e a ansiedade mostram-se neste trecho por meio do discurso indirecto livre, do ritmo rápido dado por oraçóes curtas, interrogaçóes, repetiçóes (non, non, nihil... aut) que dão vigor a essa agitação, misturada com indignação como seria possível faltarem os sinais de distinção (centurionem ad tutelam, militem, comitatus soliti) de feminae inlustres?

Os soldados sentem-se ofendidos por lhes ter sido retirada a confiança para cuidar da família do seu general. No entanto, o maior ressentimento é sentido por Agripina e o filho virem a ser

${ }^{95}$ Palavra de conotação militar (OLD s.v. agmen 5); v. 1.69.1.

${ }^{96}$ Depois de triste, o manuscrito encontra-se corrompido. 
entregues à confiança estrangeira dos Tréviros (externae fidei $)^{97}$. As oraçóes elípticas de nominativo exprimem a agitação dos soldados $^{98}$ :

pudor inde et miseratio et patris Agrippae, Augusti aui memoria, socer Drusus, ipsa insigni fecunditate, praeclara pudicitia; iam infans in castris genitus, in contubernio legionum eductus, quem militari uocabulo Caligulam appellabant, quia plerumque ad concilianda uulgi studia eo tegmine pedum induebatur (1.41.2).

Neste passo, distinguem-se dois momentos: o primeiro é o de enunciação dos parentescos e das qualidades de Agripina; o segundo refere a criança. A infans ligam-se (assindeticamente) dois particípios (a seguir sublinhados) e dois complementos circunstanciais de lugar onde (que reenviam para um ambiente militar, mas de paz, onde a criança pode nascer e ser educada), num paralelismo sintáctico evidente: in castris genitus; in contubernio eductus. A esta criança chamavam os soldados 'Botinha', porque era comum ${ }^{99}$ ele andar calçado com botinhas de soldado, com o fim de captar o carinho e dedicaçáo do povo (cf. 1.69.4).

Num ambiente marcadamente sentimental e familiar como o descrito, é natural que os soldados se achassem no direito de reivindicar aqueles que lhes são queridos, fazendo tudo para que permaneçam junto deles ${ }^{100}$ : orant obsistunt, rediret maneret, pars Agrippinae occursantes, plurimi ad Germanicum regressi (1.41.3). A aflição surge expressa pela concentração de verbos de movimento e de um particípio presente ${ }^{101}$ (denotando a simultaneidade de acção de pars e de plurimi): obsistunt, rediret, occursantes, regressi $i^{102}$. A maior parte das tropas vai ter com Germânico, que vê na circunstância motivo para se dirigir a eles, explanando o que motivou aquela decisão.

${ }^{97}$ Cf. sed nihil aeque flexit quam inuidia in Treuiros (1.41.3).

98 Trata-se de uma forma de expressão agramatical, mas que representa o sentimento do exército: cf. Goodyear 1972286.

${ }^{99}$ A frequência com que isto acontecia é ainda expresso pelo imperfeito do indicativo induebatur.

100 Sem esquecer o ressentimento que sentiam relativamente aos Tréviros (1.41.3; cf. 1.41.2).

${ }^{101}$ A pressa na realização destas acções reflecte-se ainda na construção assindética.

102 É ainda notável o efeito conseguido pelos prevérbios: num primeiro momento, utiliza-se duas vezes $a b$ - ('partida'), a que se opóe agora o uso de re- ('regresso', movimento de novo). 
O discurso (capítulos 42 e 43) revela uma estrutura rigorosa, mostrando que Germânico também tem qualidades de orador ${ }^{103}$. Goodyear 1972 288, entende este discurso adequado à situaçáo discursiva pela simplicidade dos argumentos e da estrutura; "on the other hand the pathetic and emotional tone of the speech consorts well with Germanicus' behaviour at earlier and later stages of the mutiny" ${ }^{104}$ :

Non mibi uxor aut filius patre et re publica cariores sunt, sed illum quidem sua maiestas, imperium Romanum ceteri exercitus defendent. coniugem et liberos meos, quos pro gloria uestra libens ad exitium offerrem, nunc procul a furentibus summoueo, ut quidquid istud sceleris imminet, meo tantum sanguine pietur, neue occisus Augusti pronepos, interfecta Tiberii nurus nocentiores nos faciat ${ }^{105}$ (1.42.1).

O discurso inicia-se com uma palavra de polaridade negativa (non), estabelecendo dois planos distintos mas relacionados com a mesma entidade, ou seja, o eu que surge representado no pronome mihi. Assim, uxor aut filius apresentam um eu enquanto marido e pai, ao passo que patre et re publica o apresentam como filho e cidadáo. Os planos são colocados lado a lado, numa perspectiva comparativa - compara-se a estima que o eu sente relativamente a uns e a outros ${ }^{106}$. Uma conjunção adversativa altera esta polaridade (sed) e demonstra que o eu não precisa de proteger o pai porque a sua maiestas o defende e há outros exércitos que asseguram o imperium romanum.

O retomar, em uariatio, dos vocábulos uxor e filius do início (agora denominados coniugem et liberos ${ }^{107}$ ) reforça a expressão do eu e de pertença (meos). Em contraste com esta progressiva proximidade

${ }^{103} \mathrm{Ou}$ seja, que lhe são atribuídas, ao contrário de Druso, filho de Tibério (rudis dicendis, 1.29.1); cf. 2.83.3.

${ }^{104} \mathrm{O}$ mesmo autor reproduz a divisão do discurso em partes feita por R. Ullmann (La technique des discours, 218-19): proémio (principium a re) 1.42.1, tractatio (com amplificatio) 1.42.2-43.3 e conclusão (invocação e apóstrofe; com amplificatio) 1.43.3-4.

105 Sigo Goodyear 1972. Na edição de C. D. Fisher, faciant.

${ }^{106}$ Notável é o uso de diferentes conjunçóes que, mais do que simples variação, dão orientaçóes semânticas subtis ao enunciado. Fica-se na dúvida se uxor e filius serão tão importantes em disjunção quanto pater e res publica em adição.

107 De filius, singular, passou-se a liberos, plural. Germânico pode estar a considerar agora também o filho que está por nascer ou os outros ainda não referidos na narrativa. A dúvida é legítima, principalmente porque, no final da frase, se volta ao singular, pronepos (e de novo em 1.43.4). Cf. Miller 1992163. 
com os que lhe são mais queridos, a família, passa a estar uma segunda pessoa (uestra, istud, uos), ou seja, os soldados a quem Germânico se dirige. Sem referências a traços positivos, a eles ligam-se palavras como furentibus, exitium, sceleris, sanguine, occisus, interfecta, nocentiores, representativas dos campos lexicais da loucura, crime e morte. A decisão de afastar a família - num preciso momento e para um espaço longe dos furentes - tem que ver, como mostram as oraçóes finais, com um sentimento de condescendência; no caso de ser necessário expiar qualquer crime, Germânico oferece a sua vida em sacrifício para poupar o bisneto de Augusto e a nora de Tibério.

No segundo parágrafo assiste-se a uma série de quatro interrogações directas que exteriorizam a indignação de Germânico:

quid enim per hos dies inausum intemeratumue uobis? quod nomen huic coetui dabo? militesne appellem, qui filium imperatoris uestri uallo et armis circumsedistis? an ciuis, quibus tam proiecta senatus auctoritas? hostium quoque ius et sacra legationis et fas gentium rupistis (1.42.2).

Pela estrutura, as quatro interrogaçóes podem agrupar-se em pares. As duas primeiras perguntas iniciam-se com pronomes interrogativos (quid, quod) e têm como resposta as duas seguintes, ambas dependentes de appellem por disjunção (-nel an), expressando a indecisão em como apelidar semelhante assembleia. As respostas disjuntivas mostram que à segunda pessoa do plural continuam a estar associados os maiores crimes - note-se o registo negativo de inausum, intemeratum, coetui e como os verbos circumsedistis e rupistis, associados aos respectivos complementos ${ }^{108}$, acentuam o tom de crítica. Germânico apela, assim, para os homens enquanto militares (milites: imperatoris, uallo, armis, circumsedistis) e enquanto cidadãos (ciuis: senatus, auctoritas), sublinhando-se desse modo o desrespeito pelas hierarquias.

A partir daqui, irá registar-se uma nítida mudança no tom do discurso, quando Germânico apela para exemplos que constituem uma coloração especial no enunciado, pela invocação de figuras históricas com autoridade ${ }^{109}$ reconhecida:

${ }^{108}$ Os curtos segmentos frásicos criam um ritmo na enumeração desses crimes, exprimindo o tópico da quebra de auctoritas em relação não só ao imperator e ao senatus, mas também ao ius, à sacralidade da delegação e à lei dos povos.

${ }^{109}$ Autoridade essa que não é reconhecida pelas legiōes a que se dirige. 
diuus Iulius seditionem exercitus uerbo uno compescuit, Quirites uocando qui sacramentum eius detrectabant: diuus Augustus uultu et aspectu Actiacas legiones exterruit: nos ut nondum eosdem, ita ex illis ortos si Hispaniae Syriaeue miles aspernaretur, tamen mirum et indignum erat. primane et uicesima legiones, illa signis a Tiberio acceptis, tu tot proeliorum socia, tot praemiis aucta, egregiam duci uestro gratiam refertis? (1.42.3).

A alusão a Júlio César e a Augusto, evocados de modo a acentuar a sua condição divina e por consequência extra-humana, contrasta com um simples nos ${ }^{110}$, cujo referente é, naturalmente, Germânico.

É significativa a evocação destes exemplos (César, Augusto, nós), pois com eles Germânico começa a referir os seus ouvintes — foi com estas legióes que se fez a história de Roma:

bunc ego nuntium patri laeta omnia aliis e prouinciis audienti feram? ipsius tirones, ipsius ueteranos non missione, non pecunia satiatos: hic tantum interfici centuriones, eici tribunos, includi legatos, infecta sanguine castra, flumina, meque precariam animam inter infensos trahere (1.42.4).

A identificação deste exército com a história e a causa romana ${ }^{111}$ explica a repetição ipsius... ipsius: aqueles que ouvem o discurso são os mesmos recrutas e veteranos ${ }^{112}$, agora sem se satisfazerem com licenças e dinheiro, que combateram ao lado de Tibério. Haverá, pois, de o mesmo Tibério se agradar por só as suas legióes, de entre todas, terem aqueles comportamentos, contrários aos valores romanos? Com a comparação com outras legiôes (cf. 1.42.3), Germânico não só alimenta o orgulho dos seus ouvintes, pelo passado que viveram (é igualmente uma forma de captatio beneuolentiae), como parece envergonhá-los, de modo a distingui-los pela negativa.

${ }^{110} \mathrm{O}$ motivo por que esta é a primeira vez que no discurso surge uma $1 .^{\mathrm{a}}$ pessoa do plural não é claro. Há a possibilidade de incluir Tibério (identificado como pai em 1.42.1 e 1.42.4, e general dos soldados em 1.42.3), o que seria coerente com a continuação deste plural em ut nondum eosdem, ita ex illis ortos. Em alternativa, o plural pode justificar-se com o uso majestático ou de modéstia, pela variação discursiva.

${ }^{111}$ É importante recordar que este é um dos motivos por que as legióes se revoltaram (v. 1.31.4).

${ }^{112}$ As mesmas legióes que conseguiram pulcherrima nas Germânias (1.34.4). 
O resto do discurso confirma uma significativa mudança de tom - desaparecem as interrogaçóes; os membros frásicos curtos e simples e as evocaçóes históricas (agora a Augusto e a Druso) têm função diversa:

Cur enim primo contionis die ferrum illud, quod pectori meo infigere parabam, detraxistis, o inprouidi amici? melius et amantius ille qui gladium offerebat. cecidissem certe nondum tot flagitiorum exercitui $i^{113}$ meo conscius; legissetis ducem, qui meam quidem mortem inpunitam sineret, Vari tamen et trium legionum ulcisceretur. neque enim di sinant ut Belgarum quamquam offerentium decus istud et claritudo sit subuenisse Romano nomini, compressisse Germaniae populos. tua, diue Auguste, caelo recepta mens, tua, pater Druse, imago, tui memoria isdem istis cum militibus, quos iam pudor et gloria intrat, eluant hanc maculam irasque ciuilis in exitium hostibus uertant (1.43.1-3).

A assembleia não é hostilizada pela associação a crimes inumeráveis, usa-se o vocativo o improuidi amici, alude-se ao passado, mas noutra perspectiva (recupera-se o episódio de Calusídio, em 1.35.5). A semântica é alterada: aparecem vocábulos de polaridade positiva, como decus, claritudo, pudor, gloria, valores náo perdidos, mas recuperados — para o que contribui a alteração do modo verbal dominante (expressa-se agora desejo: neque sinant, eluant, uertant).

O discurso, circular, é concluído com o resumo dos pedidos de Germânico aos soldados ${ }^{114}$, agora com outras feiçôes e outro fervor:

uos quoque, quorum alia nunc ora, alia pectora contueor, si legatos senatui, obsequium imperatori, si mihi coniugem et filium redditis, discedite a contactu ac diuidite turbidos: id stabile ad paenitentiam, id fidei uinculum erit (1.43.4).

Baseado na História recente de Roma e destes exércitos, o discurso projecta-se agora para o futuro, uma vez que os soldados estáo vinculados, pelo seu passado, à fides.

As palavras do general foram acolhidas unanimemente (1.44.1), pois os soldados, tornados suplicantes com o discurso (supplices ad haec), reconheceram a verdade da censura (uera exprobari

113 Sigo Goodyear 1972. Na edição de C. D. Fisher, exercitu.

${ }^{114}$ Retoma-se, com as alteraçóes anotadas, o vocabulário do início mihi coniugem et filium. 
fatentes). Retractando-se, é a vez de eles pedirem a punição dos culpados, o perdão dos faltosos e que Germânico os conduzisse contra o inimigo: orabant puniret noxios, ignosceret lapsis et duceret in hostem (1.44.1) — frases curtas e rápidas (tricolon) sintetizam o pedido da comunidade, marcado pelos conjuntivos no imperfeito, e formam um grupo, que se distingue dos desejos já expressos. $\mathrm{O}$ último pedido, assinalado a negrito, vai ao encontro da súplica de Germânico no final do seu discurso (1.43.3): irasque ciuiles in exitium hostibus uertant. Com efeito, é significativo que seja esta a reacção imediata dos soldados, pois revela claramente a recuperação do carisma do líder.

Outros pedidos foram feitos a Germânico: o regresso da esposa e da criança ${ }^{115} \mathrm{e}$ - argumento fundamental porque desencadeou a inveja inicial ${ }^{116}$ — que Calígula não fosse tratado como refém dos Gauleses ${ }^{117}$ :

reuocaretur coniunx, rediret legionum alumnus neue obses Gallis traderetur. reditum Agrippinae excusauit ob inminentem partum et hiemem: uenturum filium: cetera ipsi exsequerentur (1.44.1).

Ainda que cedendo em parte, Germânico não aceitou que Agripina permanecesse no acampamento. Os motivos do afastamento da mulher já não são, porém, os de segurança em risco devido à loucura criminosa dos soldados, mas sim a aproximação do parto e o rigor do Inverno. No entanto, o filho regressaria para junto dos soldados. Depois disto, começam os julgamentos, marcados por alguns excessos, que Germânico nada faz para deter, tendo antes resolvido enviar os veteranos para longe das legióes:

ueterani haud multo post in Raetiam mittuntur, specie defendendae prouinciae ob imminentis Suebos ceterum ut auellerentur castris trucibus adhuc non minus asperitate remedii quam sceleris memoria (1.44.4).

115 Com efeito, legionum alumnus faz sobressair o carinho que as legióes sentiam por Calígula, uma vez que alumnus tem a mesma raiz de alo, 'alimentar' (próximo de educare e augere; Ernout - Meillet 1959 s.v. alo).

116 1.41.2: sed nibil aeque flexit quam inuidia in Treuiros.

${ }^{117}$ A subida do particular (Tréviros) para o geral (Gauleses) é algo pejorativa, o que o uso de obses confirma. 
A concepção da figura de Germânico denuncia maior complexidade e profundidade psicológica em casos como este, em que se regista o confronto entre o que diz (os veteranos são enviados para a Récia para defender a província) e o que verdadeiramente pretende (afastá-los da violência): activa-se a isotopia aparência-realidade (specie-ceterum).

A situação de revolta está, finalmente, apaziguada, mas ainda há turbulência no acampamento de Inverno das legióes $\mathrm{V}$ e XXI (1.45.1, cf. 1.37.1). Tendo sido estas as primeiras a iniciar o motim e a cometer as acçôes mais vergonhosas, não se mostravam flexíveis: sem recear castigos, nem demonstrar remorsos, mantêm a ira. Uma vez reconquistada a fidelidade das outras legióes, Germânico pode agora tomar uma atitude enérgica, ameaçando os soldados com força armada (1.45.2): caso não se rendam, atacaria os infractores (defectores). Para tal, envia uma carta a Cecina (responsável por essas legióes) a avisar da sua chegada e da matança indiscriminada (promisca caedes) a que os rebeldes se sujeitavam se náo castigassem os culpados antes de ele chegar (1.48.1). Cecina dá a conhecer esta ameaça, às escondidas (occulte), aos porta-bandeiras, ao porta-águia e aos melhores elementos, pedindo que se evite a infâmia do exército e a morte de inocentes (1.48.2). Por isso, prepara-se, em reunião com os melhores, o castigo dos piores elementos (1.48.3), iniciando-se a matança:

Diuersa omnium, quae umquam accidere, ciuilium armorum facies. non proelio, non aduersis e castris, sed isdem e cubilibus, quos simul uescentis dies, simul quietos nox habuerat, discedunt in partis, ingerunt tela. clamor uulnera sanguis palam, causa in occulto; cetera fors regit (1.49.1).

É evidente o tom lúgubre com que a cena é descrita, pois a fraca presença de verbos realça o vocabulário do campo lexical da guerra (ciuilium armorum, proelio, castris, tela), mas principalmente a perspectiva do vencido (clamor, uulnera, sanguis). A ignorância do motivo (causa in occulto ${ }^{118}$ ) acrescenta um tom ainda mais sinistro à narrativa, pois há pessoas a morrer sem saberem porquê. Daqui resulta, assim, que alguns dos boni também tenham sucumbido, uma vez que os pessimi pegaram em armas. Sem hierarquias superiores que moderassem a contenda, à soldadesca tudo foi permitido, vingança e saciedade (permissa uulgo licentia atque

${ }^{118}$ Foi occulte (1.48.2) que Cecina começou a preparar a punição dos culpados. 
ultio et satietas). Tal como as legióes I e XX se ilibaram da desonra pela carnificina dos culpados, também estas (V e XXI) acabaram por matar os seus companheiros.

Depois da chegada de Germânico - que chora ao confrontar-se com este cenário, descrevendo o acontecido náo como cura, mas como desastre (non medicinam... sed cladem) e ordenando a cremação dos corpos - ao acampamento, a reacção dos soldados faz com que a narrativa recupere do tom triste que havia adquirido com a descrição da chacina:

Truces etiam tum animos cupido inuolat eundi in hostem, piaculum furoris; nec aliter posse placari commilitonum manis quam si pectoribus impiis honesta uulnera accepissent. sequitur ardorem militum Caesar iunctoque ponte tramittit duodecim milia $e$ legionibus, sex et uiginti socias cohortis, octo equitum alas, quarum ea seditione intemerata modestia fuit (1.49.3).

Cumpre-se o desejo expresso por Germânico no seu discurso: os soldados voltam o seu espírito violento contra o inimigo. Este tópico volta a ser focado por Germânico no combate travado contra os Germanos, quando este avisa a XX legião de que aquele era o momento para esquecer o motim e transformar a culpa em honra: uoce magna hoc illud tempus obliterandae seditionis clamitabat: pergerent, properarent culpam in decus uertere (1.51.3).

A ofensiva foi rápida e eficaz para o lado dos Romanos, mas o narrador realça o facto de estes soldados estarem a combater contra pessoas que não esperavam o ataque, adormecidas e desarmadas (sine uulnere milites, qui semisomnos, inermos aut palantis ceciderant, 1.51.1). No fim da pilhagem, o motim é considerado ultrapassado: quietum inde iter, fidensque recentibus ac priorum oblitus miles in hibernis locatur (1.51.4).

\subsection{O HERÓI DA HISTÓRIA}

As acçóes narradas, que centram Germânico em contexto hostil de uma grande revolta, ajudam a explicar a sua falência enquanto personagem em quem o povo investiu a sua esperança. Com efeito, é inegável que Germânico auferia uma adesão popular desproporcionada. Sabe-se que essa adesão (que surge traduzida no texto como studium, spes, fauor, ou mesmo adulatio ${ }^{119}$ ) é uma

${ }^{119}$ Em 2.12.1, demonstra-se que Germânico não confia na adulatio dos amigos. 
espécie de continuação do carisma de Druso, seu pai. Na verdade, esse facto chega a ser uma isotopia ao longo da sua história, já que esta relação familiar é afirmada diversas vezes no decorrer do texto. Um passo significativo dessa ligação é este, que contrasta a personalidade de Germânico com a de Tibério:

quippe Drusi magna apud populum Romanum memoria, credebaturque, si rerum potitus foret, libertatem redditurus; unde in Germanicum fauor et spes eadem ${ }^{120}$. nam iuueni ciuile ingenium, mira comitas et diuersa ab Tiberii sermone uultu, adrogantibus et obscuris (1.33.2).

A forma credebatur reenvia para o tempo da acção pelo tempo imperfeito do indicativo e, pela forma impessoal, para a generalização da ideia de crença de que, se fosse ele a governar, teria trazido de volta a liberdade, ou seja, a restauração da república ${ }^{121}$. O fauor, ligado a Germânico (cf. 1.7.6), revela a adesão popular à sua personalidade e contribui para que esta seja uma das personagens mais carismáticas dos Annales.

No trecho, está presente de forma bem vincada o contraste entre as personagens Germânico e Tibério: têm características diuersae, o que lhes confere polaridades opostas. De um lado, expóe-se a juventude (iuueni), o talento de um verdadeiro cidadão, a assinalável gentileza — traços positivos na personalidade de quem poderia (note-se que a condicional, relativa a Druso, exprime um facto irreal) governar Roma. No outro lado, pela conversa e pelo aspecto exterior (ab sermone uultu, cuja formulação assindética faz transparecer a característica principal do imperador), a ambiguidade e dissimulação, que é a polaridade negativa (adrogantibus ${ }^{122}$ e obscuris concorrem para a caracterização interior da personalidade) de quem governa Roma. A paternidade de Germânico surge-lhe associada desde a primeira vez em que é referido na obra:

${ }^{120}$ Cf. 2.73.3, onde se lamenta o facto de Germânico não ter assumido o poder.

121 Lembre-se que, no início da obra (1.1.1), libertatem et consulatum surgem como hendíadis do regime republicano. A expressão res publica aparece em Tácito quase sempre com o sentido de "Estado". Semelhante emprego encontra-se em 2.82.2. Cf. Ag. 3.1: Nerua Caesar res olim dissociabilis miscuerit, principatum ac libertatem.

${ }^{122}$ A adrogantia é uma das características de Tibério. Logo em 1.10.7 lê-se, em testemunho do povo: adrogantiam saeuitiamque eius introspexerit. 
Germanicum Druso ortum octo apud Rhenum legionibus [Augustus] inposuit adscirique per adoptionem a Tiberio iussit, quamquam esset in domo Tiberii filius iunenis, sed quo pluribus munimentis insisteret (1.3.5).

Neste passo, como se viu antes, é a vontade de Augusto que se cumpre (como denunciam as formas activas inposuit, iussit ${ }^{123}$ ), quer na atribuição do cargo a Germânico, quer na ordem de adopção. Tibério surge como paciente de vontade alheia, o que nesta construção se concretiza na função de agente da passiva ${ }^{124}$.

Dos desígnios de Augusto decorrem duas interpretaçóes possíveis: (1) Augusto queria, simplesmente, garantir que haveria outra pessoa, mais nova do que Tibério, a assegurar o poder; (2) Augusto não queria que Tibério lhe sucedesse e via em Germânico as qualidades que o filho da sua mulher não tinha. A primeira hipótese é plausível na medida em que, sendo Tibério mais velho, asseguraria o poder até morrer, dando tempo de amadurecimento de outro sucessor. Esta decisão inserir-se-á, assim, na política de linhagem de Augusto, uma vez que juntar a Druso outro jovem na linha de sucessão reforça os munimenta.

Noutra perspectiva, antes indicada com (2), pode inferir-se que Augusto preferia que Germânico lhe sucedesse, preterindo Tibério e o seu filho Druso (dando nova interpretação à oração concessiva). Esta hipótese pode sustentar-se no testemunho dos rumores; Augusto não tinha preocupaçóes de estado em adoptar Tibério e censurava-o com aparência de desculpas:

ne Tiberium quidem caritate aut rei publicae cura successorem adscitum, sed quoniam adrogantiam saeuitiamque eius introspexerit, comparatione deterrima sibi gloriam quaesiuisse. etenim Augustus paucis ante annis, cum Tiberio tribuniciam potestatem a patribus rursum postularet, quamquam honora oratione, quaedam de habitu cultuque et institutis eius iecerat, quae uelut excusando exprobraret (1.10.7).

Depois da morte de Augusto, Tibério não assumiu as funçôes que cabiam antes ao princeps, mas passou a dar ordens às coortes

${ }^{123}$ Mais do que vontade, os verbos em causa, inpono e iubeo exprimem ordem, mostrando a autoridade que Augusto ainda detinha.

${ }^{124}$ Pode depreender-se desta subtileza que Tibério não queria o poder e que foi a sua máe que influenciou Augusto nesse sentido, como demonstra Woodman 199836 e 159-162. 
pretorianas, como se fosse seu comandante, fazia-se acompanhar de sentinelas, homens armados e séquito. Estas atitudes (que originaram a crença de que Tibério apenas estava hesitante em tomar o poder quando falava no Senado ${ }^{125}$ ) mostram o terror (formido) relativamente à possibilidade de Germânico vir a reclamar o poder ${ }^{126}$. $\mathrm{Na}$ verdade, se este concentrava todo o carisma que o distinguia de Tibério, nada o impediria de querer o poder absoluto:

causa praecipua ex formidine ne Germanicus, in cuius manu tot legiones, immensa sociorum auxilia, mirus apud populum fauor, habere imperium quam exspectare mallet. dabat et famae ut uocatus electusque potius a re publica uideretur quam per uxorium ambitum et senili adoptione inrepsisse (1.7.6-7).

Também aqui se verifica uma unanimidade em relação a Germânico. O apoio militar (immensa auxilia) e o apoio civil ${ }^{127}$ (mirus fauor) poderiam fazê-lo decidir-se (ne mallet) a tomar o poder (habere imperium) em vez de o esperar (exspectare). $\mathrm{O}$ vocabulário que caracteriza Germânico concorre para a sua elevação, enquanto a concepção de Tibério se faz através da aparência (famae, ut, uideretur), com que tenta iludir a realidade, conhecida da opinião pública ${ }^{128}$.

Por motivos que se ligam à sua lealdade, Germânico recusa o poder, oferecido pelas suas próprias legióes, como se viu. $\mathrm{O}$ medo de Tibério mostra-se, desta maneira, infundado. Germânico revela a mais profunda pietas em relaçáo a Tibério, seu pai adoptivo e sucessor de Augusto. Cumpre igualmente a fides, apesar de Germânico ter todas as condiçóes de linhagem para assumir o poder à morte de Augusto, pois a adopção por Tibério coloca-o inequivocamente na linha de sucessão.

São, assim, de realçar as referências ao seu passado - o avô Marco António (alusão especialmente relevante na visita ao promontório de Áccio, 2.53.2), a mãe Antónia (3.3.2) — e ao

${ }^{125}$ Mais um elemento que contribui para se perceber que talvez Tibério não quisesse o poder. Woodman 1998 40-69 interpreta, contra o consenso geral dos estudiosos, as cenas mais significativas na subida de Tibério ao poder.

${ }^{126}$ Como se verá na análise da cena da morte de Germânico, este também tem medo de Tibério.

${ }^{127} \mathrm{O}$ mesmo apud populum [romanum] e o mesmo fauor de 1.33.1.

${ }^{128} \mathrm{O}$ narrador, transmitindo os testemunhos da opiniáo do povo, revela o papel de Lívia (ambitum) na adopção de Tibério por Augusto, já envelhecido (senili). 
da sua esposa, Agripina ${ }^{129}$, neta de Augusto (recordem-se 1.40.3, 2.71.4, 3.4.2, 4.52.2).

No entanto, mais relevantes para a demonstração do carácter de Germânico são os contactos concretos que tem com o passado, feitos em Teutoburgo ${ }^{130}$ (que funciona como trampolim para a campanha contra os Germanos), em Áccio (onde experimenta sentimentos ambíguos, magnaque illic imago tristium laetorumque, pois a sua linhagem mistura a família de Augusto com a de Marco António ${ }^{131}$ ), e no Egipto, cujas maravilhas deseja conhecer ${ }^{132}$.

De igual importância nesta relação com a História são as alusóes à sua descendência, tantas vezes recordada ${ }^{133}$. Germânico tem seis filhos (2.71.4): Nero Júlio César, Druso César, Gaio Calígula, Agripina (futura mãe de Nero), Júlia Drusila e Júlia Livila (2.54.1) ${ }^{134}$. Deste ponto de vista, Germânico é a personagem do futuro, que se projecta na sua prole ${ }^{135}$. Ainda assim, não deve

${ }^{129}$ Germânico e Agripina foram o modelo de casal exemplar; ela é diversas vezes caracterizada como pudica, mas também se mostra semper atrox (Cap. 3, sec. 1); ele, homem de uma mulher só (2.73.2).

${ }^{130} \mathrm{O}$ episódio da descoberta e enterro dos despojos das legióes mortas em Teutoburgo (1.61.1-62.2) constitui uma bela e comovente narrativa. Durante a campanha na Germânia, Lúcio Estertínio vence os Brúcteros e incendeia os seus bens, descobrindo no meio do massacre e pilhagem a águia da XIX legião, perdida por Varo. Perseguindo os sobreviventes, os soldados romanos devastam completamente o território entre os rios Amísia e Lúpia. Como esta regiáo era perto do desfiladeiro de Teutoburgo, onde os restos mortais de Varo e suas legióes se mantinham insepultos, Germânico mostra o desejo de enterrar e prestar a última homenagem àquelas legiôes e ao seu líder. Para uma análise literária da descrição do espaço e das cerimónias que aí ocorrem, v. Woodman 1998 70-85.

${ }^{131}$ Germânico aproveita uma paragem na viagem para a Síria para reparar a frota e visitar Áccio (2.53.2). Sobre a ascendência de Augusto e de M. António, v. 2.43.5, 2.53.2, 3.3.2.

132 Germânico demonstra grande vontade e curiosidade em conhecer locais exóticos e célebres pela sua história. O Egipto é um exemplo significativo dessa característica: Germanicus Aegyptum proficiscitur cognoscendae antiquitatis (2.59.3).

${ }^{133}$ A frequência de referências à fecundidade de Agripina concorre para sublinhar igualmente a prole de Germânico. Sobre a fecundidade e pudicícia de Agripina, v. Cap. 3, sec. 1.

${ }_{134}$ Quase todos acabam por ter um fim trágico: Druso (6.23.2), Nero (6.24.2), Agripina (14.8.5). Na porção perdida dos Annales, seria ainda narrada a morte de Calígula e das irmás: v. Furneaux 1891 5-14. Sobre o fim de Druso e de Nero, v. Cap. 3, sec. 2. O orgulho que Germânico sente pela sua prole manifesta-se ainda na decisão de os levar no carro triunfal (augebat intuentium uisus eximia ipsius species currusque quinque liberis onustus, 2.41.3).

${ }^{135}$ No dizer de O'Gorman 2000 46, “[a]s a father, brother and grandfather of three successive Julio-Claudian emperors, Germanicus acquires historical significance retrospectively.” 
esquecer-se a relação que ele próprio estabelece com o devir. Ilustrativo deste aspecto é o episódio em que ele consulta o oráculo de Apolo:

igitur adito Ilio quaeque ibi uarietate fortunae et nostri origine ueneranda, relegit Asiam adpellitque Colophona ut Clarii Apollinis oraculo uteretur ... et ferebatur Germanico per ambages, ut mos oraculis, maturum exitum ${ }^{136}$ cecinisse (2.54.2-4).

A curiosidade em saber o passado está, assim, ligada à vontade de saber o futuro.

Como foi dito, à volta de Germânico cria-se uma atmosfera de esperanças (por ser filho de Druso e pelas suas famosas qualidades de carácter) e de empatia (pela sua condição de vítima dos odia do tio e da avó) que contribui para a sua popularidade. Esse aspecto, várias vezes expresso, irá resultar numa mágoa profunda aquando da sua morte, acontecimento que é sugerido pelo narrador, quando descreve o triunfo de Germânico:

sed suberat occulta formido, reputantibus haud prosperum in Druso patre eius fauorem uulgi, auunculum eiusdem Marcellum flagrantibus plebis studiis intra iunentam ereptum, breuis et infaustos populi Romani amores (2.41.3).

Germânico entra, em comparação com o pai e com o tio, num paradigma trágico que arrebata ao povo romano os seus amores. Este aviso de mau augúrio desvenda um fim desditoso (infaustos) e próximo (breuis) para Germânico. De facto, a seguir ao triunfo do sobrinho e filho adoptivo, Tibério, não conseguindo o fauor do povo, pondera destruí-lo (amoliri, 2.42.1).

136 Este passo traz algumas ambiguidades: "The adjective maturum can mean both 'occurring at the proper time' and 'occurring before the proper time'; and, though the manuscript here has exitium ('extermination'), some scholars prefer to read exitum, which means 'departure' or 'death' (whether natural or otherwise) and is the word used by Germanicus himself in his last speech at 2.71.1 below": Woodman 200467 n.92. 


\section{Pisáo e Plancina. A morte de Germânico}

Quando, em 2.43.1, Tibério declara que os problemas da Arménia não podem ser resolvidos senão pela sapientia de Germânico, o senado confia ao filho adoptivo do imperador as províncias quae mari diuiduntur, outorgando-lhe um maius imperium que o coloca acima dos governadores das províncias públicas e imperiais:

Igitur haec et de Armenia quae supra memoraui ${ }^{137}$ apud patres [Tiberius] disseruit, nec posse motum Orientem nisi Germanici sapientia conponi: nam suam aetatem uergere, Drusi nondum satis adoleuisse. tunc decreto patrum permissae Germanico prouinciae quae mari diuiduntur, maiusque imperium, quoquo adisset, quam iis qui sorte aut missu principis obtinerent (2.43.1).

Esta decisão é tomada por decreto do senado (cf. 3.12.1). Germânico é, assim, afastado de vez dos exércitos da Germânia, onde gozava de grande notoriedade. Em 2.26.2, o narrador diz que em cartas frequentes (crebris epistulis), Tibério aconselhava Germânico a regressar para o triunfo que lhe havia sido concedido (v. 1.55.1): tinha tido resultados e perigos suficientes (satis iam euentuum, satis casuum). Teve sucesso em grandes batalhas (prospera illi et magna proelia), mas deveria recordar também as perdas infligidas pelos ventos e tempestades, que, náo tendo sido culpa sua (nulla ducis culpa), eram pesadas e cruéis (grania tamen et saeua damna). Germânico cede, consciente da inuidia de que era alvo (2.26.5).

Surge, no entanto, um conflito, indiciado pela conjunção adversativa (sed), quando Tibério substitui Crético Silano por Pisão no governo da Síria: sed Tiberius demouerat Syria Creticum Silanum, per adfinitatem conexum Germanico, quia Silani filia Neroni uetustissimo liberorum eius pacta erat, praefeceratque Cn. Pisonem (2.43.2). O imperador retira do cargo um homem de confiança de Germânico ${ }^{138}$ para o atribuir a outro, cujo espírito

${ }^{137} \mathrm{O}$ narrador refere-se a 2.3.1 e 2.4.3-5.1.

${ }^{138}$ A filha de Silano é noiva de Nero, filho mais velho de Germânico. A declaração das boas relaçóes entre os dois, Germânico e Silano, contrasta com as relaçóes hostis que serão mantidas entre Germânico e Pisão. Esta mudança 
violento virá a fundamentar a suspeita de que matou Germânico. Começa assim a turbulenta relação entre Pisão e Germânico.

Gneu Calpúrnio Pisão ${ }^{139}$ é referido no início dos Annales como um dos nomes possíveis para suceder a Augusto. A personagem é enquadrada num perfil semelhante ao de Lúcio Arrúncio: non indignum et si casus daretur ausurum (1.13.3). No geral, este passo - que conta os supremi sermones que Augusto teve com Tibério, acerca de possíveis sucessores capazes para o poder, e que R. Syme 1958694 considera como "clumsy" — é de difícil interpretação ${ }^{140}$. Ainda assim, afigura-se pertinente sublinhar esta afirmação: omnesque praeter Lepidum uariis mox criminibus struente Tiberio circumuenti sunt (1.13.3). Com efeito, se omnes inclui o nome de Pisão ${ }^{141}$ (que apareceu em alternativa ${ }^{142}$ ), é legítimo deduzir o patrocínio de Tibério na perda de Pisão, uma vez que tal poderá ter que ver com a maquinação de acusações de que se fala (struere crimen $^{143}$ ). Trata-se de um indício (logo na primeira referência à personagem) de que o fim de Pisão será orquestrado pelo imperador.

O carácter desafiador, arrogante e impulsivo de Pisão torna-se notório em breves episódios de que é protagonista, em $1.74 .5^{144} \mathrm{e}$ 2.35. $1^{145}$. Em ambos os casos, Pisão reclama o que resta (ou parece restar) da libertas entretanto perdida: uestigia morientis libertatis (1.74.5), speciem libertatis (2.35.1). Esse carácter é herdado do pai, mas justifica-se principalmente devido à riqueza e influência da esposa, Plancina:

no governo da província parece vir confirmar as suspeitas quanto às ordens (e má vontade) de Tibério contra Germânico.

139 Filho de Gneu Calpúrnio Pisão (2.43.2), nasceu c. 42 a.C., foi governador da Hispânia Citerior (3.13.1), cônsul em 7 d.C., juntamente com Tibério. Enviado como legado consular para a Síria (entre os anos 17-19; 2.43.2), onde foi adiutor de Germânico.

${ }^{140}$ Como comprova a problematização de Goodyear 1972 181-184.

${ }^{141}$ Goodyear 1972183 acredita que sim.

142 1.13.3: pro Arruntio quidam Cn. Pisonem tradidere.

${ }^{143}$ Também na acusação de Tício Sabino se maquinou (struo) um dolus.

${ }^{144} \mathrm{O}$ narrador apresenta como exemplo de restos de liberdade moribunda o facto de Pisão ter enfrentado Tibério, questionando o sentido do voto do princeps para que os senadores evitassem votar contra o imperador. Cf. O'Gorman 200042.

${ }^{145}$ No senado debate-se que papel tem esse órgão na ausência do imperador. Gneu Pisão, que tem uma opinião diferente de Asínio Galo, considera que o senado deve continuar as suas funçóes. 
ingenio uiolentum et obsequii ignarum, insita ferocia a patre Pisone (...) sed praeter paternos spiritus uxoris quoque Plancinae nobilitate et opibus accendebatur; uix Tiberio concedere, liberos eius ut multum infra despectare (2.43.2-3). ${ }^{146}$

Confirma-se a psicologia provocadora desta personagem, bem como a sua arrogância, nomeadamente contra Germânico, a quem se julgava superior — aliás, o constante boicote às ordens de Germânico é a negação da sua autoridade.

Em focalização interna, o narrador denuncia a interpretação que Pisão fez das ordens recebidas de Tibério ${ }^{147}$ :

nec dubium habebat se delectum qui Syriae imponeretur ad spes Germanici coercendas. credidere quidam data et a Tiberio occulta mandata; et Plancinam haud dubie Augusta monuit aemulatione muliebri Agrippinam insectandi. diuisa namque et discors aula erat tacitis in Drusum aut Germanicum studiis (2.43.4).

São aqui expressos vários dados importantes para o desenrolar da história. É a primeira vez que se afirmam as suspeitas de que Pisão terá recebido ordens secretas de Tibério. Para Pisão não havia dúvida de que a sua nomeação servia para travar as pretensóes de Germânico — algo que, com efeito, não implica, necessariamente, o assassínio deste. Aquilo em que alguns acreditavam, a existência de ordens secretas, nunca será inteiramente provado, como se verá (Haynes 200311 e 12). Daquilo que parece haver a certeza é do envolvimento de Plancina e Augusta, e das ordens para prejudicar Agripina (cf. 2.43.4). Aliás, Plancina, na Síria, incentiva os militares (ultrapassando os limites das tarefas de mulher, indo além daquilo que se considera honroso numa mulher: Santoro L'hoir 2006 119-120) contra Agripina e Germânico (2.55.6).

146 Sublinham-se as características dominantes de Pisão. É de notar que, à luz das palavras posteriores de Pisão (cum fide aduersum te neque alia in matrem tuam pietate, 3.16.3), a expressão obsequii ignarum é irónica.

${ }^{147}$ Walker 1952116 n.1 lembra os passos em que se faz referência às orientaçóes de Pisão na Síria - 2.43.2-3: decreto patrum permissae Germanico prouinciae (...) maiusque imperium ... praefeceratque [Syriae] Cn. Pisonem; 2.70.3: [Germanicus] componit epistulas (...) addunt plerique iussum prouincia decedere; 2.74.1: Consultatum inde inter legatos quique alii senatorum aderant quisnam Syriae praeficeretur; 2.76.1: os amigos de Pisão dizem repeteret prouinciam non iure ablatam; 2.77.1: Domício diz Pisonem, non Sentium Syriae praepositum. Cf. também 2.79.5, 2.80.3, 3.12.2. 
Para cumprir o seu desígnio, ao chegar à Síria, Pisão começa uma mudança nas chefias militares, substituindo as antigas pelos seus clientes. Atinge tal grau de corrupção que passa a ser chamado "pai das legióes". As alegadas instruçôes de Tibério desencadeiam uma série de ofensas lançadas por Pisão contra Germânico, relativamente a quem (lembre-se) se sentia superior. Deste facto são testemunho episódios como os seguintes.

Em viagem para a Síria, Germânico passa por Atenas, onde é recebido com pompa (2.53.3). Pisão reage à forma como Germânico foi recebido na cidade, criticando Atenas e, assim, também Germânico - a entrada de Pisão é turbulenta e, num discurso cruel, afirma que Germânico foi prestar homenagem a um monte de esterco:

oratione saeua increpat, oblique Germanicum perstringens quod contra decus Romani nominis non Atheniensis tot cladibus extinctos, sed conluniem illam nationum comitate nimia coluisset (2.55.1).

As palavras de Pisão confirmam o seu carácter violento (increpat, saeua, perstringens, conluuiem), mas sublinham o seu orgulho romano (decus Romani nominis).

A relação entre ambos conhece novo momento de tensão em 2.57.1, quando Germânico regressa da Arménia e fica a saber que Pisão não cumpriu as suas ordens de conduzir (ele ou o filho) parte das legióes para aquele território:

Cunctaque socialia prospere composita non ideo laetum Germanicum habebant ob superbiam Pisonis qui iussus partem legionum ipse aut per filium in Armeniam ducere utrumque neglexerat. Cyrri demum apud hiberna decumae legionis conuenere, firmato uultu, Piso aduersus metum, Germanicus ne minari crederetur; et erat, ut rettuli, clementior (2.57.1-2).

A expressão de cada um denuncia, novamente, as personalidades respectivas (superbiam, neglexerat; clementior). Quanto a Germânico, é de realçar a sua inclinaçáo para tratar Pisão com clemência, pelo que a culpa para a deterioração da relação de ambos parece ser a superbia de Pisão, como ilustra o uso do complemento circunstancial de causa.

É muito significativo, para entender a hostilidade entre as duas personagens, que os amigos de Germânico, astutos em influenciar 
o seu sentido de ofensa, incriminem Pisão e a sua família de várias formas e com mentiras: sed amici accendendis offensionibus callidi intendere uera, adgerere falsa ipsumque et Plancinam et filios uariis modis criminari (2.57.2). Os avisos dos amigos e a consciência de que estava a ser afrontado ${ }^{148}$ contribuem para a caracterização de Germânico enquanto alguém brando mesmo para os inimigos ${ }^{149}$. Ao invés, os amigos surgem caracterizados de acordo com os intriguistas da obra: callidi ${ }^{150}$, pois escondem as verdades e inventam falsidades: cf. 3.12.3, onde Tibério insiste na possibilidade de as acusações contra Pisão serem falsas, e 3.16.3, na carta em que Pisáo afirma que o acusam de falsidades. Assim, os amigos de Germânico configuram uma personagem colectiva com as qualidades de um intriguista-modelo. $\mathrm{O}$ sucesso do expediente é tal que acabam por influenciar decididamente o comportamento de Germânico, que se altera de condescendente para inflexível. Noutro ponto de vista, pode ainda conjecturar-se que, se Germânico não se sentia ameaçado, é porque não acreditava que Pisão fosse efectivamente uma ameaça ${ }^{151}$ : e que só passa a considerá-lo uma ameaça quando os amigos fabricam falsidades e escondem a verdade. Começam a inverter-se os papéis de acusador-vítima.

No final do encontro, eles odiavam-se um ao outro abertamente - à conversa zangada e dissimulada de um, responde o outro com truculência. A progressiva degradação das relaçóes entre Pisão e Germânico manifesta-se, assim, na gradação iniciada pela correctio da adversativa sed e culmina em postremo:

postremo paucis familiarum adhibitis sermo coeptus a Caesare, qualem ira et dissimulatio gignit, responsum a Pisone precibus

${ }^{148}$ Em 2.55.2. A consulta do oráculo de Cólofon (2.54.4) pode também significar um aviso.

149 2.72.2: mansuetudo; v. 2.55.3, em que salvou Pisão porque tanta mansuetudine agebat; cf. mansura (2.70.1), com que aquela palavra tem ligação etimológica, e 2.13.1, onde os soldados lhe é atribuem patientia.

${ }^{150}$ Ou seja, 'astutos, manhosos'. É de notar que o vocabulário usado neste passo é próximo daquele que é usado em relação a Tibério; por exemplo, offensionibus callidi e uariis modis criminari em relação aos amigos de Germânico têm eco em callidus et noui iuris repertor (2.30.3) e uariis (...) criminibus struente Tiberio (1.13.4), respectivamente.

151 Seria surpreendente se Germânico se encontrasse (efectivamente) sob ameaça e nada fizesse para a travar. Talvez essa tolerância (provavelmente excessiva, como clementior, 'demasiado clemente', pode querer dizer) seja um sinal de reconhecimento de que a razão estava do lado de Pisão. 
contumacibus; discesseruntque apertis odiis. post quae rarus in tribunali Caesaris Piso, et si quando adsideret, atrox ac dissentire manifestus (2.57.3).

Pisão passa a mostrar-se discordante e violento de modo ostensivo. O desentendimento faz-se já abertamente (apertis, que contrasta com algumas acçóes tomadas na ausência ou sem o conhecimento do outro).

A narrativa do banquete oferecido pelo rei dos Nabateus exemplifica e pormenoriza o tipo de relações que passam a ter:

uox quoque eius audita est in conuinio, cum apud regem Nabataeorum coronae aureae magno pondere Caesari et Agrippinae, leues Pisoni et ceteris offerrentur, principis Romani, non Parthi regis filio eas epulas dari; abiecitque simul coronam et multa in luxum addidit quae Germanico quamquam acerba tolerabantur tamen (2.57.3-4).

Se é verdade que Pisão estaria inclinado para criticar Germânico a qualquer pretexto, em outros momentos da narrativa ele apareceu como um republicano, pelo que esta censura, que ilustra paradigmaticamente os comportamentos incompatíveis de ambos, tem força acrescida, pois a referência à monarquia (coronae, regis, coronam) e ao luxo é visivelmente pejorativa.

Apesar de tudo (quamquam acerba ... tamen), Germânico tolera essa atitude, levando ao extremo a sua patientia (2.13.1), que irá mudar.

\subsection{A MORTE de Germânico}

Como demonstrei, nos encontros que reúnem Germânico e Pisão conhece-se um adensar de tensão que culminará na ruptura das relaçóes entre ambos, depois de uma visita de embaixadores dos Partos. O rei Artabano pedia o restabelecimento do pacto de aliança com Roma (cf. 2.1.2) e dispunha-se a ir até ao rio Eufrates para render vassalagem a Germânico, mas em troca solicitava a este que Vonones fosse afastado da Síria (v. 2.4.3), vedando-lhe assim a facilidade nos contactos sediciosos com a aristocracia parta (2.58.1). Germânico aceita a proposta dos embaixadores de Artabano e manda exilar Vonones na Cilícia: 
datum id non modo precibus Artabani, sed contumeliae Pisonis cui gratissimus erat ob plurima officia et dona quibus Plancinam deuinxerat ${ }^{152}(2.58 .2)$.

A inversão de papéis é notória, pois a ofensa tem agora origem numa decisão de Germânico e atinge Pisão e Plancina (cuja actuação por meio de plurima officia e dona configura o seu carácter).

As relaçóes entre Germânico e Pisão atingem a total ruptura e incompatibilidade depois do regresso de Germânico do Egipto $^{153}$ :

At Germanicus Aegypto remeans cuncta quae apud legiones aut urbes iusserat abolita uel in contrarium uersa cognoscit. hinc graues in Pisonem contumeliae, nec minus acerba quae ab illo in Caesarem intentabantur. dein Piso abire Syria statuit (2.69.1-2).

Reforça-se a desobediência de Pisão, que agora não só não cumpriu as ordens, como as anulou e subverteu. Depois de uma acesa discussão com Germânico — em que este volta a proferir contumeliae contra Pisão, adjectivadas de graues (rompendo com a sua tolerância em face dos ataques de que é vítima) e que têm uma resposta não menos violenta (dada em lítotes e comparativo: nec minus acerba, tal como em 2.57.4) — Pisão acaba por decidir abandonar a Síria.

A retirada não chega a ocorrer porque Germânico adoece:

mox aduersa Germanici ualetudine detentus, ubi recreatum accepit uotaque pro incolumitate soluebantur, admotas hostias, sacrificalem apparatum, festam Antiochensium plebem per lictores proturbat. tum Seleuciam degreditur, opperiens aegritudinem, quae rursum Germanico acciderat (2.69.2).

A doença (denominada aduersa (...) ualetudine, aegritudinem; em 2.69.3, morbi) conhece momentos de melhoras e de recaída (como expressa a cadência mox, recreatum, rursum, acciderat).

152 "A zeugma, since Artabani is subjective genitive and Pisonis objective", diz Goodyear 2004 372. O verbo devinxerat surge em 1.3.4, a propósito de Lívia Augusta (v. Cap. 2, sec. 2).

${ }^{153}$ A viagem ao Egipto configura, relativamente a Germânico, um exemplo de oposição entre a verdade e a aparência. Visita locais famosos para satisfazer a curiosidade, mas usa como pretexto a cura prouinciae. 
Esses momentos têm repercussão na movimentação espacial de Pisão, que se afasta (abire, 2.69.1, degreditur, 2.69.2, decedere, 2.70.2), não demora (nec moratus, 2.70.2) ou espera (opperiens, 2.69.2), aproxima-se e regressa à Síria.

Pelo comportamento que teve anteriormente e porque não permite que se façam votos pela recuperação de Germânico ${ }^{154}$, Pisão faz criar à sua volta uma atmosfera de suspeita, recaindo sobre ele a acusação de ser responsável (por recurso a veneno e feitiços) pelo estado de saúde de Germânico. Essas suspeitas surgem quando se descobrem provas de que se teria atentado contra a saúde de Germânico e são alimentadas pela opinião pública, ideia impressa pelas construçóes impessoais e na passiva:

saeuam uim morbi augebat persuasio ueneni a Pisone accepti; et reperiebantur solo ac parietibus erutae humanorum corporum reliquiae, carmina et deuotiones et nomen Germanici plumbeis tabulis insculptum, semusti cineres ac tabo obliti aliaque malefica quis creditur animas numinibus infernis sacrari (2.69.3).

Não só a evidência das provas é clara, como Pisão continua a agir sem preocupação de mostrar inocência. $O$ envio de emissários para saber da saúde de Germânico (simul missi a Pisone incusabantur ut ualetudinis aduersa rimantes, 2.69.3) pode ir nesse sentido, mas este facto é entendido como desconfiança. Cria-se uma atmosfera tenebrosa, evocada pela concentração de vocábulos do campo lexical ligado às artes maléficas (ueneni, erutae humanorum corporum, carmina, plumbeis tabulis, semusti cineres, tabo, obliti, malefica, numinibus infernis), que a sucessão de sons oclusivos (nasais e orais), intercalados com sons vocálicos a e $e$, realçam.

Ao tomar conhecimento disto, que lhe provoca ira e receio ${ }^{155}$, Germânico convence-se de que Pisão é o culpado pelo seu estado, uma vez que este pretendia o domínio sobre a província e o comando supremo das legióes:

${ }^{154}$ Trata-se de uma atitude que denuncia a sua vontade e que deve ser comparada com a forma como Pisão e Plancina recebem a notícia da morte de Germânico: quo intemperanter accepto caedit uictimas, adit templa, neque ispe gaudium moderans et magis insolescente Plancina, quae luctum amissae sororis tum primum laeto cultu mutauit (2.75.2; cf. 2.76.2).

155 A expressão haud minus ira quam per metum tem um sentido de complementaridade acentuado pela correctio (e pela uariatio ablativo-per com acusativo) que a simples copulativa não confere. 
ea Germanico haud minus ira quam per metum accepta. si limen obsideretur, si effundendus spiritus sub oculis inimicorum foret, quid deinde miserrimae coniugi, quid infantibus liberis enenturum? lenta uideri ueneficia: festinare et urgere, ut prouinciam, ut legiones solus habeat. sed non usque eo defectum Germanicum, neque praemia caedis apud interfectorem mansura (2.70.1).

Neste passo, a narrativa flui em focalização interna, pelo que é às interrogaçóes e à angústia de Germânico que o leitor tem acesso. É a sua amargura que fica expressa em formas como effundendus spiritus, miserrimae, ueneficia, nas interrogaçóes e conjunção $u t$ repetidas (frisando a urgência da actuação de Pisão), e na preocupação de a morte ocorrer em frente aos inimigos (inimicorum $^{156}$, interfectores ${ }^{157}$ ).

Testemunhas diziam que, convencido de que ia morrer assassinado, Germânico cortou relações de amizade com Pisão, expulsando-o da Síriaa ${ }^{158}$; este, pela primeira vez, acata as suas ordens:

componit epistulas quis amicitiam ei renuntiabat: addunt plerique iussum prouincia decedere. nec Piso moratus ultra nauis soluit moderabaturque cursui quo propius regrederetur si mors Germanici Syriam aperuisset (2.70.2).

Pisão aguardava a morte de Germânico, mas para tomar a Síria, confirmando-se a sua pretensão em alcançar o governo da província.

A cena da morte de Germânico está repleta de elementos dramáticos. Germânico, como se viu, perdeu a tolerância e a paciência que o caracterizavam em face das afrontas do inimigo. Cortou as relaçóes com Pisão, agora que acreditava seriamente que morria devido às manobras dele. Depois de uma última e breve melhoria nas condiçóes de saúde (de que resulta, uma vez mais, esperança de recuperação ${ }^{159}$ ), e quando o seu corpo se ressente dos sinais de doença (fesso corpore) — sinal de um fim próximo —, Germânico inicia um discurso, que dirige aos amigos:

${ }^{156}$ Germânico pensava que os mensageiros enviados por Pisão pretendiam verificar se ele morria (si limen obsideretur, sub oculis inimicorum).

${ }^{157}$ Denota-se já que se trata de um assassínio.

${ }^{158}$ Recorde-se que Pisão era o governador da província, mas Germânico tinha mais poder do que ele (sobre o maius imperium, cf. Cic. Phil. 11.11.30).

${ }^{159}$ A spes também é referida no discurso de Germânico. 
Caesar paulisper ad spem erectus, dein fesso corpore ubi finis aderat, adsistentis amicos in hunc modum adloquitur: si fato concederem, iustus mihi dolor etiam aduersus deos esset, quod me parentibus liberis patriae intra iuuentam praematuro exitu raperent: nunc scelere Pisonis et Plancinae interceptus ultimas preces pectoribus uestris relinquo: referatis patri ac fratri, quibus acerbitatibus dilaceratus, quibus insidiis circumuentus miserrimam uitam pessima morte finierim (2.71.1).

Expresso em oratio recta, o discurso é emitido em tom amargo, por alguém que tem consciência de que é muito novo para morrer (praematuro exitu, iuuentam, interceptus ${ }^{160}$ ). Mesmo que fosse por acção do destino (fato), ser-lhe-ia legítimo revoltar-se até contra os deuses (iustus... dolor etiam aduersus deos). A criaçáo de tal cenário hipotético dá maior relevo à mensagem que transmite, pois não é esta condição que se verifica. $\mathrm{O}$ advérbio nunc, com sugestão adversativa, corrige essa versão, apresentando em alternativa a da culpabilização de Pisão e Plancina (scelere, insidiis). Germânico faz um pedido solene (preces) aos amigos (amici, assim referidos em 2.71.1, 71.4 e 71.5), aqui expressos por pectoribus uestris, metonímia que realça o lado afectivo da sua relaçáo com eles: que divulguem os motivos e as circunstâncias da sua morte. $\mathrm{E}$ precisamente a ideia de morte e do pesar que ela lhe causa que domina todo o passo - sem que um vocábulo com essa acepção seja repetido: fato, concederem, dolor, (praematuro) exitu, raperent, interceptus, ultimas, uitam, finierim, morte.

Germânico, que, como se demonstrou, havia aguentado a superbia e sucessivos agravos de Pisão, dá-lhes aqui uma expressão: acerbitatibus e insidiis documentam essa vivência que lhe tornou a vida infeliz (ideia que nunca antes havia sido expressa).

A reiteração da ideia de esperança (que no passo citado surge como uma configuração da isotopia realidade-aparência, pois ela desencadeia um sentimento vazio que não se verifica na realidade), bem como a da projecção de Germânico na História (reforçada em seguida), surgem nestes termos:

${ }^{160}$ A imagem produzida com o verbo raperent (exprimindo movimento brusco e violento, realçado pelo complemento com intra, 'no meio') retoma um tema caro a Germânico nos seus discursos, a família (filhos e pai; cf. 1.34.4 e principalmente 1.42.1-43.4). 
si quos spes meae, si quos propinquus sanguis, etiam quos inuidia erga uiuentem mouebat, inlacrimabunt quondam florentem et tot bellorum superstitem muliebri fraude cecidisse. erit uobis locus querendi apud senatum, inuocandi leges (2.71.2).

A repetição de si e de quos (reforçado na última ocorrência por etiam) ${ }^{161}$ realça a impossibilidade de que alguém não venha a chorar a sua morte, quer seja seu apoiante, quer seu amigo ${ }^{162}$, evocando como motivo o facto de sucumbir a uma emboscada armada por uma mulher ${ }^{163}$ (referindo-se, naturalmente, a Plancina ${ }^{164}$ ). É importante sublinhar o contraste entre o passado (quondam) florescente, de alguém que estava na força da vida e das suas qualidades (florentem, bellorum superstitem) e a situação a que Pisão e Plancina o fizeram chegar.

$\mathrm{O}$ pedido para que se intente um processo judicial (querendi, senatum, lege) baseia-se nas obrigaçóes dos melhores amigos:

non hoc praecipuum amicorum munus est, prosequi defunctum ignauo questu, sed quae uoluerit meminisse, quae mandauerit exequi. flebunt Germanicum etiam ignoti: uindicabitis uos, si me potius quam fortunam meam fouebatis. ostendite populo Romano diui Augusti neptem eandemque coningem meam, numerate sex liberos. misericordia cum accusantibus erit fingentibusque scelesta mandata ${ }^{165}$ aut non credent homines aut non ignoscent. (2.71.4).

A correctio (non... sed...) surge aqui como reforço da ideia de dever que os melhores amigos têm. O futuro surge como a oportunidade de vingança de uma morte injusta e como meio de Germânico não vir a ser esquecido. Desencadeia-se neste passo

${ }^{161}$ Pela repetição, confere-se ao discurso do jovem moribundo um ritmo cansado.

${ }^{162}$ Logo depois (2.71.3), Germânico afirma que mesmo os que nunca o conheceram vão chorar a sua morte. Depois de morrer, é o que se verifica.

${ }^{163}$ Em rigor, esta afirmação ilibaria Pisão do assassínio de Germânico, no entanto, como se viu, este acha-o igualmente culpado. Deve ter-se em atenção que não culpa Tibério pela sua desdita (para proteger a mulher e os filhos, como se percebe em 2.72.1).

164 Goodyear 2004 413: "Poison is a woman's weapon". Ainda que Germânico acredite que a culpa da sua morte seja de envenenamento por Pisão e Plancina, o testemunho do texto do narrador não o afirma claramente. No entanto, são de realçar os vocábulos ligados ao crime e à intriga, abundantes neste discurso: scelere, insidiis, fraude.

${ }^{165}$ É inegável a relação que o vocábulo mandata tem com os occulta mandata que Tibério teria dado a Pisáo (2.43.4); cf. ainda 3.16.1. 
também a isotopia da vingança (uindicabitis, reforçada em 2.71.5 por ultionem) de Germânico, que acompanhará a narrativa até ao fim do julgamento e morte de Pisão. A esse desafio, respondem os amigos deste modo: iurauere amici dextram morientis contingentes spiritum ante quam ultionem amissuros (2.71.5). Os amigos de Germânico comprometem-se a vingá-lo. De novo, o discurso plasma um forte sentimento de estima, pela expressão de duas versóes comparadas: preferem perder a vida a deixar de vingar Germânico.

As últimas palavras de Germânico foram para a sua querida esposa Agripina:

Tum ad uxorem uersus per memoriam sui, per communis liberos orauit exueret ferociam, saeuienti fortunae summitteret animum, neu regressa in urbem aemulatione potentiae ualidiores inritaret. haec palam et alia secreto per quae ostendisse credebatur metum ex Tiberio (2.72.1).

Recuperam-se dois temas fundamentais: o da família (uxorem, liberos) e o da História (memoriam). O destino é considerado cruel e Agripina é aconselhada a submeter-lhe a sua ferocia ${ }^{166}$, e a não provocar os detentores do poder (Germânico não se quer comprometer ao criticar abertamente Tibério e, por isso, utiliza esta fórmula impessoal). A conversa teve dois momentos, um testemunhado por várias pessoas, e outro em segredo, como se verifica pela antítese palam-secreto. Acreditava-se (credebatur) que Germânico teria expressado medo em relação a Tibério (pelo que poderia fazer à sua família).

Não muito depois destas conversas, Germânico morre ${ }^{167}$. A descrição do pesar que o seu desaparecimento provocou

${ }^{166} \mathrm{O}$ carácter de Agripina vai sendo delineado ao longo da obra: em 1.33.3, revela-se que tem más relaçôes com Augusta (accedebant muliebres offensiones nouercalibus Liniae in Agrippinam stimulis, atque ipsa Agrippina paulo commotior, nisi quod castitate et mariti amore quamuis indomitum animum in bonum uertebat); em 2.75.1, afirma-se que pretendia a rápida vingança da morte do marido (At Agrippina, quamquam defessa luctu et corpore aegro, omnium tamen quae ultionem morarentur intolerans); 4.52.2: semper atrox; 4.53.1: peruicax irae; 6.25.2: aequi impatiens, dominandi auida, uirilibus curis feminarum uitia exuerat. $\mathrm{O}$ orgulho em pertencer à descendência de Augusto manifesta-se particularmente em 1.40.3: cum se dino Augusto ortam neque degenerem ad pericula testaretur.

${ }^{167}$ Foram os supremi sermones que dificilmente estarão desligados daqueles referidos no início da obra, a propósito de Augusto (1.13.2). Em ambos, estão presentes os avisos em relação ao futuro e aos perigos que ele traz. 
mostra em que medida era amado por todos, respondendo aos seus últimos anseios de que não fosse esquecido:

neque multo post extinguitur, ingenti luctu prouinciae et circumiacentium populorum. indoluere exterae nationes regesque: tanta illi comitas in socios, mansuetudo in hostis; uisuque et auditu iuxta uenerabilis, cum magnitudinem et grauitatem summae fortunae retineret, inuidiam et adrogantiam effugerat (2.72.2).

Realça-se aqui que Germânico conquistou o respeito de todos, inclusive dos reis e naçóes estrangeiras (uenerabilis). Apesar de ter sido investido de muita autoridade e poder, das summae fortunae retivera (retineret) apenas a magnitudinem et grauitatem, evitando assim o que elas habitualmente têm de inuidiam et adrogantiam.

Com efeito, no funeral a única coisa a que se deu relevo foram os louvores e a memoria uirtutum eius (2.73.1) ${ }^{168}$. De imediato, surge o paralelo com Alexandre Magno:

et erant qui formam, aetatem, genus mortis ob propinquitatem etiam locorum in quibus interiit, magni Alexandri fatis adaequarent. nam utrumque corpore decoro, genere insigni, haud multum triginta annos egressum, suorum insidiis externas inter gentis occidisse ${ }^{169}$ (2.73.1-2).

"Four items in the first sentence, beauty, age, manner of death, proximity of place of death, are succeeded by five in the second sentence, beauty, distinguished birth, age, manner of death, death in foreign lands" (Goodyear 2004 417).

Quando morre Augusto, houve rumores que recordaram uana porque relacionavam a morte do imperador com a do seu pai (1.9.1). No entanto, neste passo, este tipo de recordação tem uma função diversa, pois confirma, por comparação com outra personagem, as características que têm vindo a ser atribuídas a Germânico:

sedhunc [= Germanicum] mitem erga amicos, modicum uoluptatum, uno matrimonio, certis liberis egisse, neque minus proeliatorem, etiam si temeritas afuerit praepeditusque sit perculsas tot uictoriis Germanias seruitio premere ${ }^{170}$. quod si solus arbiter rerum, si iure et

${ }^{168}$ Que o facto de ter sido um funus sine imaginibus et pompa reforça, porque não se apela para a memória dos seus antepassados.

${ }_{169}$ Tal como Armínio, por exemplo: dolo propinquorum cecidit (2.88.2).

${ }^{170}$ Em 2.26.4, Germânico pede a Tibério mais um Verão para concluir a subjugação da Germânia, concessão que o imperador não faz. 
nomine regio fuisset, tanto promptius adsecuturum gloriam militiae quantum clementia, temperantia, ceteris bonis artibus praestitisset (2.73.2-3).

Desta comparação resultaumengrandecimento dapersonalidade de Germânico (mitem, modicum, temeritas, clementia, temperantia), que em nada é inferior a Alexandre, pelo contrário ${ }^{171}$.

\subsection{A VinganÇA DE GERMÂNico}

Após a morte de Germânico, a Síria é entregue a Sêncio, depois de um debate acerca de quem deveria assumir o governo da província (2.74.1). A Pisão, que estava ausente, deparam-se duas alternativas. A primeira seria aceitar que a província passasse para as mãos de Sêncio e regressar a Roma, mostrando-se inocente do sucedido. Assim o aconselha seu filho Marco Pisão (2.76.2-3), uma vez que nenhum acto imperdoável tinha ainda sido perpetrado (nibil adhuc inexpiabile admissum), e ele náo devia temer nem leves suspeitas nem rumores infundados (suspiciones imbecillas aut inania famae pertimescenda). O desentendimento com Germânico não lhe garantiria punição, talvez apenas ódio (discordiam erga Germanicum odio fortasse dignam, non poena). Quanto ao governo da Síria, desistir dele evitaria a guerra civil (quod si regrederetur, obsistente Sentio, ciuile bellum incipi). De facto, a recordação do seu general recentemente desaparecido e a profunda estima que tinham para com os Césares não permitiria o apoio dos centurióes e militares por muito tempo (nec duraturos in partibus centuriones militesque, apud quos recents imperatoris sui memoria et penitus infixus in Caesares amor praeualeret, 2.76.3).

Em vez disso, Pisão poderia optar por reclamar a província que lhe pertencia, adiando o regresso, sem prestar esclarecimentos ao príncipe e ao senado, uma vez que ter cumprido as ordens que tinham sido dadas (propria mandata) lhe dava confiança para isso. É o que defendem os centurióes e Domício Célere, um dos seus amigos mais próximos $(2.76 .1,2.77)$. Uma vez que se deve deixar passar algum tempo para atenuar os rumores (relinquendum etiam rumoribus tempus quo senescant) ${ }^{172}$, e visto o imperador e Augusta estarem do seu lado (ainda que de forma oculta), não havia que recear a permanência na Síria:

${ }^{171}$ Cf. Goodyear 1972 32-33 e Goodyear 2004 418-419.

${ }^{172}$ A demora no regresso a Roma será vista como um meio de apagar as provas do crime (3.7.1). 
an festinamus cum Germanici cineribus adpellere, ut te inauditum et indefensum planctus Agrippinae ac uulgus imperitum primo rumore rapiant? est tibi Augustae conscientia, est Caesaris fauor, sed in occulto, et perisse Germanicum nulli iactantius maerent quam qui maxime laetantur (2.77.3).

Este excerto, que corresponde ao discurso directo de Domício Célere, confirma a importância que os argumentos por ele aduzidos têm para a decisão de Pisão. Tal como se havia verificado em relação a Germânico, será o conselho dos amigos a conduzir a personagem a um erro de avaliação das circunstâncias e, por inerência, da sua conduta (hamartia). Pisáo opta, pois, por ficar e envia uma carta a Tibério, onde censura Germânico de arrogância e excesso de luxo (2.78.1) ${ }^{173}$.

Após a morte de Germânico, o comportamento de Pisão, assim como o modo como é descrito, começam a alterar-se. Pisão duvida sobre o que fazer (quid agendum consultanti, 2.76.2), era-lhe mais fácil (pela sua própria natureza; cf., e.g., 2.57.1) ser levado para as soluçóes mais violentas, preferindo, por isso, o pior: Haud magna mole Piso, promptus ferocibus, in sententiam trahitur (2.78.1). Assim, se as decisóes que toma, baseadas nos conselhos de personagens que lhe são próximas, se revelarão erradas, ele próprio irá tomar consciência disto, mas já tarde de mais, e depois da derrota junto à fortaleza de Celênderis (2.80.1-81.3) ${ }^{174}$.

Analiso agora o episódio do julgamento de Pisão, relativamente ao qual B. Walker sublinha algumas semelhanças com o julgamento de Libão Druso: "In both there are two charges not clearly distinguished, in both the attitude of Tiberius is open to doubt, and in both the rôle of the defendant undergoes a metamorphosis during the proceedings. (...) like Libo Drusus, Piso is to appear

${ }^{173}$ Essas críticas tinham sido já feitas por Pisão no episódio do banquete oferecido pelo rei dos Nabateus. A constante lembrança de quem Germânico é descendente (motivo da visita a Áccio), ou mesmo a mansuetudo que vota à ameaça que alegadamente constitui Pisáo (cf. ainda 2.72.2) podem mostrar, do ponto de vista de Pisão, a arrogância de Germânico.

174 Pisão irá arrepender-se destes erros na sua última carta, deixada ao imperador, a quem sempre foi fiel. $\mathrm{O}$ episódio do recontro em Celênderis é fundamental para entender a forma como, progressivamente, se aproxima da sua própria ruína. A narrativa constrói-se em quadros que contrastam entre si, pois à disfunção dos que lutam do lado de Pisão (principalmente desertores, escravos e soldados enviados pelos reguli locais, in numerum legionis composuerat, 2.80.1, e sem armas a sério, 2.80.3) opóe-se a ordem dos militares que defendem a província (ueterani ordinibus ac subsidiis instructi, 2.80.3). 
finally in the role of innocent victim." ${ }^{175}$ Considero, todavia, que a metamorfose viláo-vítima não pode ser entendida como muito pronunciada, ou apenas devida a estratégias retóricas. $\mathrm{O}$ narrador transmite a crença popular de que Pisão é culpado, mas em momento algum se prova que o é de facto. Pelo contrário, o narrador alerta no fim da narrativa da vingança de Germânico (como se verá) para a ambiguidade e incerteza que envolvem o caso e salienta que não há provas quanto à relação do réu com a morte, por envenenamento, de Germânico.

No dia seguinte à aparatosa chegada de Pisão e Plancina a Roma ${ }^{176}$, começam os preparativos para o seu julgamento (3.10.1). Quem toma a iniciativa de citar Pisão judicialmente é Fulcínio Trião. Começa aqui o longo episódio do julgamento (e morte) de Pisão, que se inscreve no tema da vingança de Germânico ${ }^{177}$. A entrada de Fulcínio Trião no caso cria o primeiro conflito deste episódio, uma vez que ele encontra a oposição (contra) de Vitélio, Verânio e outros companheiros de Germânico, que ofereciam resistência (tendebant) a que Triáo tivesse algum papel neste processo.

Trião cede no seu desígnio (dimissa eius causae delatione, 3.10.1), mas não abandona o caso, contentando-se em intentar outro processo sobre a vida passada de Pisão (priorem uitam accusaret, 3.10.1). A sua participação configura um exemplo da vacuidade do papel dos acusadores profissionais, uma vez que náo vai acrescentar nada de significativo à causa ${ }^{178}$.

${ }^{175}$ Recorde-se ainda que a ligação entre os dois casos também se faz pelo acusador Fulcínio Triấo, pelo cenário nocturno em que acontece a morte, depois de um tranquilo serão (ainda que se sinta alguma tensão nessa tranquilidade).

${ }^{176} \mathrm{O}$ comportamento que Pisão e Plancina adoptam continua a provocaçáo que tem sido a sua reacção à morte de Germânico: a viagem, que se assemelha à de Germânico a caminho da Síria, faz-se despreocupada e provocadoramente, tal como os sítios por onde vão passando e o local onde aportam (no mausoléu de Augusto, 3.9.2) demonstram; o clima de alegria em 2.75.2 é confirmado com as festas e banquetes que organizam (3.9.3). O encontro com Druso a meio da viagem parece sugerir que Pisão necessita de apoio em Roma, uma vez que este espera ganhar a cumplicidade do filho de Tibério (haud fratris interitu trucem quam remoto aemulo aequiorem sibi sperabat, 3.8.1). Note-se que a isotopia da esperança acompanha Pisáo até ao momento da morte (quando a perde).

${ }^{177}$ A morte de Pisão constitui o fim dessa vingança, cuja narração se estende até 3.19.2: is finis fuit ulciscenda Germanici morte.

${ }^{178}$ Como, de resto, parece não ter acrescentado ao caso de Libão Druso, onde foram proferidas, contra um arguido sem defesa, stolida uana (2.30.2). A vacuidade do papel de Fulcínio Triâo é confirmada em 3.13.1: tum Fulcinius uetera et inania orditur. 
No meu entender, este breve episódio pretende não só mostrar o oportunismo de acusadores profissionais, como Trião - que representa o delator-acusador típico e cujo carácter é delineado no processo de implicação de Libão Druso na lex maiestatis ${ }^{179}$ : celebre inter accusatores Trionis ingenium erat auidumque famae malae (2.28.3) —, mas também para provar que os legítimos acusadores de Pisão tinham de ser os amigos de Germânico ${ }^{180}$, os quais, por seu turno, não eram simples acusadores (ou pelo menos não se consideravam acusadores), senão informadores e testemunhas: neque se accusatores sed rerum indices et testis mandata Germanici perlaturos (3.10.1). Tendo em conta a carga negativa que as funçóes de accusatores ou delatores tinham, é natural que se pretenda, para este julgamento, alterar os nomes dos papéis que os amigos de Germânico desempenham. Ainda assim, não deixam de ser acusadores (v. 3.12.3 e 6, nas palavras de Tibério, e 3.14.1, nas palavras do narrador), mas passam para o público (que têm do seu lado) uma imagem de amigos fiéis que apenas querem justiça pela morte de um herói. Trata-se, por isso, de um episódio ligado à isotopia da aparência.

A escolha do juiz também constitui um breve aparte, cuja relevância tem que ver com a (última) manifestação de altivez e confiança de Pisão, que prefere que o caso fique nas mãos de Tibério:

petitumque est a principe cognitionem exciperet. quod ne reus quidem abnuebat, studia populi et patrum metuens: contra Tiberium spernendis rumoribus ualidum et conscientiae matris innexum esse; ueraque aut in deterius credita iudice ab uno facilius discerni, odium et inuidiam apud multos ualere (3.10.1-2).

Pisão (referido já como reus) tem motivos para exteriorizar esta confiança (cf. 2.77.3): o facto de não ter de se sujeitar às inclinaçóes de outros juízes (os senadores) apenas constitui mais um argumento para que aceitasse de bom grado esta decisão. Conhece, porém, um primeiro revés — Tibério recusa ser o juiz do processo, distanciando-se assim do seu servidor ${ }^{181}$, remetendo todo o processo para o senado:

${ }^{179}$ Como se verá no Cap. 3, sec. 1 .

${ }^{180}$ Aqueles a quem Germânico pediu que iniciassem este processo.

181 De novo, o imperador mostra preocupaçóes com a fama (como por exemplo em 4.40.1, referindo-se ao casamento de Sejano com Lívia Júlia), deixando transparecer que pretende construir uma imagem distante do que realmente é; encontra-se a mesma atitude no decorrer do julgamento (onde 
haud fallebat Tiberium moles cognitionis quaque ipse fama distraheretur. igitur paucis familiarium adhibitis minas accusantium et hinc preces audit integramque causam ad senatum remittit (3.10.3).

Se se analisar Pisão como uma personagem trágica, a esperança que ele tinha na defesa que poderia receber de Tibério constitui a sua hamartia, na qual sustenta, em grande parte, a sua hybris. Começa o caminho de Pisão para a desgraça, no fim do qual a personagem estará totalmente inscrita no conjunto de vítimas e o seu papel de presumível viláo esquecido.

A selecção da defesa conhece igualmente um contratempo, oposto ao desentendimento da acusação. Se parecia haver acusadores a mais, muitos foram os que recusaram defender Pisão, sob diversos pretextos ${ }^{182}$ : Lúcio Arrúncio, Públio Vinício, Asínio Galo, Marcelo Esernino e Sexto Pompeio ${ }^{183}$. O arguido acaba por ser defendido por Marco Lépido ${ }^{184}$, Lúcio Pisão (irmão do réu) e Livineio Régulo.

Antes de iniciar o relato dos acontecimentos que envolveram a cognitio, o narrador volta a atenção para o sentimento público (arrecta omni ciuitate ${ }^{185}$ ), dando início a um discurso indirecto livre: quanta fides amicis Germanici, quae fiducia reo. Woodman - Martin 1996136 comentam assim estas palavras: "quanta suggests that the loyalty of Germanicus' friends knows no limit, quae that Piso can scarcely have any self-confidence at all"186. $\mathrm{E}$ evidente que o narrador regista o tom geral dos rumores que se espalhavam sobre o caso, e que incluíam os acusadores,

pede imparcialidade às partes pleiteadoras). É, assim, notória a presença da isotopia aparência-realidade.

${ }^{182}$ Assim também Libão Druso (2.29.1); cf. Woodman - Martin 1996 135. Nomear quem recusou defender Pisão põe em maior relevo não só esse gesto, como a perda de apoio dos colegas senadores.

${ }^{183}$ Nos Annales, alude-se diversas vezes a Lúcio Arrúncio (e.g., 1.8.3), uma das personagens com maior relevo nos livros I a VI, bem como a Asínio Galo (e.g., 1.8.3). Não há, na obra, outros registos das figuras de Públio Vinício e Esernino Marcelo.

${ }^{184}$ Sobre esta personagem, v. 3.35.1 e Sinclair 199564.

${ }^{185}$ A. J. Woodman "believes that T[acitus] is here referring to the pricking up of the cinitatis aures (...), a metaphor which suits, and is supported by, intentior and the reference to whispers and silence below" (Woodman Martin 1996 136).

${ }^{186}$ Trata-se, por isso, de mais um indício sobre o desfecho da história. 
o acusado e sobretudo o imperador: satin cohiberet ac premeret sensus suos Tiberius. [is] hand alias intentior populus plus sibi in principem occultae uocis aut suspicacis silentii permisit (3.11.2). A curiosidade popular está ligada a um tema comum, o da repressão dos sentimentos de Tibério ${ }^{187}$. São recursos como a aliteração ( $p$ e s), assonância (in-in-in-, -pulus plus -ul- -us-, si- -is -is si- -is), expressóes superlativas (haud alias intentior... plus...), e referências ao silêncio que caracterizam esse adensar emotivo ${ }^{188}$, com a aproximação do julgamento.

Depois desta introdução, tem início o julgamento propriamente dito, com um discurso de Tibério (3.12.1, caracterizado como meditato temperamento, o que sugere o carácter calculista da personagem), onde o imperador sintetiza as acusaçóes e recorda os serviços prestados por Pisão. Esta é uma estratégia discursiva que serve para recapitular a história, sob o ponto de vista de Tibério. Assente numa estrutura quase simétrica, o discurso presta atenção aos dois lados da questão, sublinhando a necessidade de se encontrar a verdade num processo caracterizado pela abundância de rumores que a escondem. $\mathrm{O}$ pedido de moderação e imparcialidade é diversas vezes repetido.

Em oratio obliqua, a história é recontada desde as relaçóes que Pisão manteve com Augusto:

patris sui legatum atque amicum Pisonem fuisse adiutoremque Germanico datum a se auctore senatu rebus apud Orientem administrandis. illic contumacia et certaminibus asperasset iuuenem exituque ${ }^{189}$ eius laetatus esset an scelere extinxisset, integris animis diiudicandum (3.12.1).

Pisão foi legado do pai de Tibério (Augusto será evocado por Pisão na carta que deixa depois da morte) e seu amigo (cf. 3.16.3). Recorda-se a responsabilidade de Tibério (partilhada com o senado) em ter nomeado Pisáo como coadjutor de Germânico para a administração dos assuntos do Oriente.

O que se pretende provar com este julgamento é problematizado com a introdução da disjuntiva an, após o díctico de localização

${ }^{187}$ Cf. 1.4.3, 1.11.2, 1.69.5, 3.15.2, 3.64.2, 4.57.1-2, 4.71.3, 6.8.4, 6.50.3 (Woodman - Martin 1996 136).

${ }^{188}$ Recursos em Woodman - Martin 1996 136; interpretação minha.

189 A referência iuuenem exitu é muito semelhante à do discurso de Germânico (2.71.1). 
espacial illic, que, referindo-se ao Oriente, indica o local do crime. Num segundo momento, o discurso aparece em oratio recta, o que não está desligado do conteúdo da mensagem. As generalidades referidas no primeiro momento são substituídas por particularizaçóes que se referem a acontecimentos concretos, relacionados directamente com o que está a ser julgado. Explicam-se as consequências (nam) que advêm de uma ou de outra alternativa:

nam si legatus officii terminos, obsequium erga imperatorem exuit eiusdemque morte et luctu meo laetatus est, odero seponamque a domo mea et priuatas inimicitias non ui principis ulciscar: sin facinus in cuiuscumque mortalium nece uindicandum detegitur, uos uero et liberos Germanici et nos parentes iustis solaciis adficite. simulque illud reputate, turbide et seditiose tractanerit exercitus Piso, quaesita sint per ambitionem studia militum, armis repetita prouincia, an falsa haec in maius unlgauerint accusatores (3.12.2-3).

Tibério pretende que se provem os excessos de Pisão (exuit) e dos amigos de Germânico (in maius). O imperador volta a apelar à imparcialidade, fundamentando esta necessidade na distinçáo que ele próprio faz entre a sua esfera privada e o seu cargo público de príncipe $^{190}$. De novo, como na introduçáo (an), a este estado de coisas junta-se uma alternativa, aqui introduzida por sin. Esta dicotomia espelha, assim, as posiçóes da acusação e da defesa. O príncipe pede um julgamento imparcial, sendo expressivos os avisos que Tibério faz no fim do discurso: primeiro, afirma que Germânico não está acima da lei, e depois que não é a sua própria dor que deve estar em tribunal, mas uma acusação que precisa de provas.

Este discurso serve, como se disse, para trazer à memória dos senadores (e do leitor) os elementos que estáo em causa neste julgamento. Tibério coloca lado a lado as posiçóes contrárias (sem se referir a provas) e, depois, pede a maior equidade aos juízes e que tanto os acusadores como os defensores cumpram os seus papéis da melhor forma possível. Citando C. Damon, esta é uma "mirror story", ou seja, uma história recontada ao longo da narrativa, focando-se perspectivas diferentes, sendo por isso "a structure that highlights the narrator's role in and authority over the narrative" (Damon 19996 145).

${ }^{190}$ Cf. Walker 1952 114. Ao mesmo tempo que lembra a relação que tem com Pisão e que pede imparcialidade no julgamento, Tibério coloca as duas partes (acusado e vítima) em igualdade. Cria-se a ilusão de que vai haver duas partes a pleitear entre si. 
Em 3.14.1, o foco narrativo ajusta-se na defesa, que hesitou, dado que não era possível negar algumas das acusaçóes de que Pisão era alvo (ambição militar, província sujeita ao que havia de pior, e ultrajes contra o comandante). Apenas a acusação de veneno foi refutada, porque os acusadores náo a provaram satisfatoriamente, uma vez que parecia absurdo que Pisão, na presença de Germânico e dos seus amigos, ousasse envenená-lo durante um banquete (3.14.2). Apesar dessa acusação não provada, Pisão estaria, antecipadamente, perdido e condenado, tanto na perspectiva de Tibério ${ }^{191}$, como na do senado ${ }^{192}$. Uma lacuna na narrativa (3.14.3) interrompe o seguimento do caso. Parece que se pediam algumas provas (possivelmente cartas) - e a perda dessa porçáo de texto pode pôr em causa a interpretação do passo (Walker 195296 n.1 e 114).

O comportamento adoptado por Pisão desde a morte de Germânico até ao julgamento é caracterizado pelo excesso de confiança por ter a consciência de que tinha o apoio de Tibério e de Augusta (contra Tiberium spernendis rumoribus ualidum et conscientiae matris innexum esse, 3.10.2), excesso que as relaçóes com Plancina reforçava. Com efeito, Plancina era alvo da mesma inuidia que durante o julgamento recai sobre Pisão, mas tinha reconhecidamente maior influência: eadem Plancinae inuidia, maior gratia; eoque ambiguum habebatur quantum Caesari in eam liceret (3.15.1). A incerteza (expressa por ambiguum e pelo conjuntivo em liceret) acompanha a opinião pública de que o narrador já havia dado conta quanto às expectativas relativamente a este julgamento em 3.11.2 — o povo estava curioso quanto à fides dos amigos de Germânico, à fiducia manifestada pelo réu ${ }^{193}$, e quanto ao nível de contençáo dos sentimentos de Tibério ${ }^{194}$.

Quando o foco narrativo se demora em Plancina, o leitor fica a conhecer o seu calculismo e falsidade: atque ipsa, donec mediae Pisoni spes, sociam se cuiuscumque fortunae et, si ita ferret, comitem exitii promittebat (3.15.1). Deve notar-se como a esperança de

${ }^{191} \mathrm{O}$ imperador encontrava-se entre os iudices (...) implacabiles por causa da sedição e distúrbios levados à província (3.14.3).

192 Os senadores não admitiram a hipótese de Germânico não ter morrido sine fraude (ou seja, que tivesse tido uma morte natural, 3.14.3). Além disso, o povo tinha também feito o seu juízo nas ruas: simul populi ante curiam uoces audiebantur: non temperaturos manibus si patrum sententias euasisset. effigiesque Pisonis traxerant in Gemonias ac diuellebant (3.14.4).

193 O vocábulo fiducia significa 'confiança', aproximando-se de audacia pelo sentido, como ensinam Ernout — Meillet 1959 s.v. fido.

194 Semelhante curiosidade testemunha o interesse que a opinião pública continuava a ter em relação a Germânico, o que justifica a inuidia para com Pisão. 
Pisão está ligada a uma ilusão, uma aparência, que se desfaz quando Plancina obtém a uenia por intercessão de Augusta, ou seja, por meio de intrigas de bastidores: ut secretis Augustae precibus ueniam obtinuit, paulatim segregari a marito, diuidere defensionem coepit (3.15.1). Pisão percebe então que, na realidade, se encontra só e irrevogavelmente perdido (quod (...) exitiabile, 3.15.2): é o fim das suas esperanças, a ponto de Pisão hesitar em continuar sem o apoio que tinha julgado garantido (cf. 2.77.3: est tibi Augustae conscientia, est Caesaris fauor, sed in occulto).

A acção precipita-se com o aumento da velocidade discursiva, verificada pela concentração de verbos, que exprimem, primeiro a dúvida, depois movimento: quod reus postquam sibi exitiabile intellegit, an adhuc experiretur dubitans, hortantibus filiis, durat mentem senatumque rursum ingreditur (3.15.2). O foco narrativo ajusta-se em Pisão e é do seu ponto de vista que o leitor tem acesso à sequência do julgamento:

redintegratamque accusationem, infensas patrum uoces, aduersa et saeua cuncta perpessus, nullo magis exterritus est quam quod Tiberium sine miseratione, sine ira, obstinatum clausumque uidit, ne quo adfectu perrumperetur (3.15.2).

Desta última impressão que Pisão experimenta resulta a certeza de que também Tibério o abandonou — é já conhecido o espectro glacial de Tibério que aterroriza os arguidos em tribunal. Mais uma vez, é possível a ligação ao caso de Libão Druso, com a diferença de que Pisão foi um fiel servidor de Tibério (cf. Walker 1952 96-97), que, sem os studia de outros, o poderia ter salvo (3.10.1).

A cena da morte de Pisão é a confirmação da sua desistência e o culminar de um adensar dramático que o seu isolamento realça (depois de ter suportado todos os ataques no senado, mas náo o abandono do princeps $\left.^{195}\right)$ :

relatus domum, tamquam defensionem in posterum meditaretur, pauca conscribit obsignatque et liberto tradit; tum solita curando corpori exequitur. dein multa post noctem, egressa cubiculo uxore, operiri foris iussit; et coepta luce perfosso iugulo, iacente humi gladio, repertus est (3.15.3).

${ }^{195}$ Recorde-se que, desde a dificuldade em arranjar defesa, passando pelo abandono da mulher, e acabando no abandono de Tibério, se tem vindo a assistir a um progressivo isolamento da personagem: só os filhos se mantiveram do seu lado, numa sentida demonstração de pietas. 
A serenidade dos actos é evidente. Ao leitor é dado saber que Pisão tomou uma atitude ponderada (meditaretur) e que escreveu um documento - que se virá a saber ser uma carta dirigida a Tibério para ser lida no senado. O cenário nocturno (multa post noctem) e a solidão (egressa ... uxore ${ }^{196}$, operiri foris) contrastam com a luz (coepta luce) e o desvendar da realidade: perfosso iugulo, iacente humi gladio, repertus est ${ }^{197}$.

A leitura da carta que Pisão escreveu na noite em que pôs termo à vida ocorre no senado na sequência da preocupação que Tibério demonstrou ao tomar conhecimento da morte dele flexo in maestitiam ore (3.16.2), depois de ter permanecido sine miseratione, sine ira, obstinatum clasumque (3.15.2) em face das acusaçóes que foram feitas contra Pisão.

A inquietação que Tibério demonstra pode representar tanto uma tristeza genuína (senão arrependimento por ter abandonado um servidor), como uma preocupação por, no último momento de vida, Pisão poder ter denunciado um plano urdido por Tibério e por Lívia para a eliminação de Germânico. A preocupaçáo com a inuidia que sobre ele recairia por causa daquela morte, e as interrogaçóes repetidas sobre como passou Pisão o seu último dia e a sua última noite, assim o sugerem.

Da resposta, faz parte a leitura da carta, em que Pisão realça as oposições inuidia-falsum crimen e ueritas-innocentia (que a focalização interna de 3.15 .2 havia indicado): conspiratione inimicorum et inuidia falsi criminis oppressus quatenus ueritati et innocentiae meae nusquam locus est (3.16.3). Pisão sente-se vítima de uma conspiração dos seus inimigos ${ }^{198}$. Pisão lembra também a fides para com Tibério e a pietas em relação a Lívia Augusta. Se denunciasse um hipotético plano (de eliminação de Germânico), quebraria esses laços. Assim, tem a coragem e a dignidade de enfrentar a morte sem incriminar ninguém. Por se considerar inocente, mas condenado, Pisão revela a coragem de antecipar um destino que parece certo à partida e, uma vez que náo teve oportunidade de defesa, apresenta um solene pedido de

196 Note-se que a mulher havia já abandonado o marido à sua sorte. Este encontro poderia significar uma derradeira tentativa de Pisão de salvar-se.

${ }^{197}$ É uma morte dramática e, por isso, ocorre fora do palco.

198 De notar o uso de conspiratio; Germânico falava em scelus, insidiae (2.71.1) e fraus (2.71.2). 
absolvição dos filhos. Apesar da inocência que alega, fala em prauitas $^{199}$ (3.16.4), que julgo estar relacionada com as decisóes que tomou após a morte de Germânico, as quais contribuíram para a incriminação: ou seja, assume a culpa por ter tentado recuperar a Síria.

Os últimos desejos de Pisão foram cumpridos porque Tibério retirou a acusação de guerra civil a Marco Pisão:

Tiberius adulescentem crimine ciuilis belli purgauit, patris quippe iussa nec potuisse filium detrectare, simul nobilitatem domus, etiam ipsius quoquo modo meriti grauem casum miseratus (3.17.1).

Mesmo quando o cônsul Aurélio Cota sugeriu apagar o nome de Pisão dos fastos, expropriar parte dos bens, e até mudar o prenome de Gneu Pisão (3.17.4), Tibério não aceitou essa proposta e vetou-a: multa ex ea sententia mitigata sunt a principe: ne nomen Pisonis fastis eximeretur (...) et M. Pisonem ignominiae exemit concessitque ei partena bona (3.18.1).

Como se disse, a atitude de arrogância de Pisão é justificada pelo narrador por dois motivos: os spiritus paterni e a nobreza e riqueza da mulher (2.43.3). De facto, Plancina é uma personagem fundamental nesta parte da história, porque ela representa o poder e influência de Augusta, papel a que está associada desde cedo, acentuando-se diversas vezes essa relaçáo de amizade ${ }^{200}$. Os planos secretos de Augusta para prejudicar Germânico e a sua família teriam Plancina como principal agente. De facto, o aparecimento de uma personagem como Martina, célebre envenenadora, amiga de Plancina, apenas acentua essa suspeita que parece ser, a todos os níveis, fundamentada (2.74.2 e 3.7.2). A absolvição de Plancina cria grande indignação no povo, nos acusadores e até no narrador: apenas Tibério falou em favor de Plancina (pro Plancina cum pudore et flagitio disseruit, 3.17.1). A ausência de referência ao nome de Plancina na carta de Pisão ${ }^{201}$

${ }^{199}$ V. Ernout - Meillet 1959 s.v. prauus. Substantivo derivado de prauus, 'torto, atravessado', antónimo de rectus. Do sentido físico, aplicado a partes do corpo, evolui para o sentido moral, 'pervertido, depravado, mau'.

${ }^{200}$ V., e.g., 2.43.3, 2.82.1, 3.15.1, 3.17.4.

201 Pode pensar-se que Pisão, tal como não quis incriminar Tibério nem Augusta, preferiu não implicar a mulher, entretanto salva. Com mais propriedade, pode conjecturar-se que náo a refere por ressentimento: ou porque foi traído por ela, ou porque foi ela a principal responsável pelos factos de que só ele é acusado (o que, como se disse, o envolvimento de Martina parece confirmar). 
contrasta com as vezes em que ela é referida depois da morte dele, como alguém que se vai salvar, mercê da amizade que a liga a Augusta, que, como em outras ocasióes, se mostra acima da lei ${ }^{202}$. Com efeito, já no fim do julgamento, Aurélio Cota expressa uma opinião justificada como uma concessão às preces de Augusta (3.17.4). Este facto parece configurar, antes de mais, um exemplo de adulatio de todo o senado e magistraturas ao imperador e à sua mãe (cf. especialmente 1.14.1), uma vez que náo se póe em causa a existência ou ausência de culpa no caso de Plancina ${ }^{203}$, mas apenas se sublinha que a sua absolvição se deve à intervenção de Augusta.

Pelas sugestóes que o narrador vai deixando no seu relato, depreende-se que, se Pisão morre inocente ${ }^{204}$, Plancina sobrevive culpada.

O episódio termina em 3.19.2:

is finis fuit ulciscenda Germanici morte, non modo apud illos homines qui tum agebant etiam secutis temporibus uario rumore iactata. adeo maxima quaeque ambigua sunt, dum alii quoquo modo audita pro compertis habent, alii uera in contrarium uertunt, et gliscit utrumque posteritate.

O narrador lamenta as incertezas que a passagem do tempo e a tradição oral criam. De facto, neste caso, a voz narrativa tinha dado uma versão (em si cheia de dificuldades de interpretação), Tibério dá no seu discurso uma nova perspectiva, que por seu lado também não está inteiramente de acordo com a versão dos acusadores (Damon 19996 151-155). No entanto, é a narrativa que conta o que verdadeiramente aconteceu, ao passo que o julgamento configura já uma versão diferente e focalizada em

${ }^{202}$ Um familiar de Pisão (o irmão) já se havia indignado com esta situação (2.34.2-4, a propósito de Urgulânia).

${ }^{203} \mathrm{O}$ debate que ocorre no senado em 3.33.1-35.3 parece indiciar que havia em Roma quem atribuísse as culpas a Plancina (3.33.3).

${ }^{204}$ De facto, Pisão parece enquadrar-se na classificação de personagem trágica. Manteve-se íntegro, foi sempre defensor da República — algo que parece partilhar com o narrador — , ainda que ferox e superbus. Ao contrário de Germânico, foi traído e abandonado por quase todos. Os seus excessos (principalmente a arrogância), o mau aconselhamento, ou simplesmente o facto de ser presa de Tibério levam-no a procurar a morte, despojado de esperança e de salvação. Ter sido acusado pelos vingadores de Germânico - e na eventualidade de não ter tido papel no envenenamento deste — , faz com que se acentuem as características de personagem trágica. 
diversas personagens: "This new version held that Germanicus had been killed, that through the trial and suicide of Piso vengeance had been accomplished" (Damon 1999b 160).

Todos os acontecimentos em torno deste episódio considerado desde a atribuição do imperium maius a Germânico e a nomeação de Pisão como governador da Síria, até ao fim da vingança da morte de Germânico - estão envolvidos em incerteza e ambiguidade. B. Walker 1952114 classificou o episódio como "a curious and baffling story", seguindo a afirmaçáo de 3.19.2: non modo apud illos homines qui tum agebant, etiam secutis temporibus uario rumore iactata. Por isso, há duas maneiras de julgar as personagens de Pisão e de Germânico, tal como o narrador afirma ser possível interpretar os sinais de envenenamento do corpo de Germânico, conforme se apoie este ou Pisão (2.73.4; Devillers 1994 168). Qualquer que seja o ponto de vista que se adopte, há que ter em atençáo diversos elementos narrativos, nomeadamente o facto de a ambiguidade resultar de conversas secretas e obscuras, verdadeiras ou criadas pela imaginação popular, que apoiava incondicionalmente Germânico.

De facto, não sendo claros os motivos que levaram Tibério a colocar Pisão à frente da Síria para ser adiutor de Germânico, pode interpretar-se o comportamento e o papel de Pisão (e, por inerência, de Tibério) de duas maneiras. A primeira é a mais simples e talvez a mais difundida. Tibério não gostava de Germânico e, para que não obtivesse glória excessiva junto das legióes da Germânia, encarregou-o das legióes do Oriente, com o pretexto de apaziguar o território da Arménia ${ }^{205}$. Pisão seria o seu vigilante e um sabotador dos sucessos de Germânico. Deste modo, quando Pisão se declara inocente, na carta lida post-mortem, depois de se sentir vítima da agressividade dos senadores e de experimentar em tribunal a mais cruel adversidade, é legítimo considerar que ele sente a injustiça de, tendo cumprido o seu dever, ser agora vítima da vingança dos amigos de Germânico (e alvo do ódio do povo, que prometia justiça pelas próprias mãos). Pisão e Plancina executaram o plano de Tibério e de Lívia e, para aparentar inocência do príncipe e da mãe, estes sacrificam o executante directo. Por isso, deve mesmo comparar-se o destino de Pisão com o de outros agentes de Lívia e de Tibério, dando crédito à afirmação do autor textual, a propósito da forma como

${ }^{205}$ Tarefa que, aliás, facilmente cumpriu com sucesso. 
Tibério trata como descartáveis os seus servidores (4.71.1).

Em alternativa, surge uma outra interpretação que se baseia numa leitura mais atenta do texto de Tácito, que distingue o conteúdo da narrativa dos Annales de outros textos paralelos (como o Senatusconsultum de Pisone Patre e as obras de Suetónio e Díon Cássio) e que, nos Annales, distingue os planos da narrativa, do comentário, de focalizaçôes internas, ou da opinião pública. Procurei demonstrar, por meio desta leitura, as contradiçóes e ambiguidades entre o que se diz e os factos, algo que a referida sobreposição de versôes ("mirror stories") realça. 
Capítulo III

Continvae Accusationes, Fallaces Amicitiae 
É consensualmente aceite que a narrativa do principado de Tibério assenta numa divisão em duas fases: a primeira caracteriza-se por uma boa governação, enquanto na segunda se verifica uma degradação da política por ele praticada, mercê da degenerescência psicológica da personagem:

nonus Tiberio annus erat compositae rei publicae, florentis domus (nam Germanici mortem inter prospera ducebat), cum repente turbare fortuna coepit, saenire ipse aut saenientibus niris praebere ${ }^{1}$. initium et causa penes Aelium Seianum cohortibus praetoriis praefectum cuius de potentia supra memoraui: nunc originem, mores, et quo facinore dominationem raptum ierit expediam (4.1.1).

A conjunção donec $^{2}$ marca o ponto de viragem, aquele em que tudo foi subvertido. O acontecimento fracturante - explicado e amplificado pela fórmula nam superfuit, mansuere (4.7.1) - foi a morte de Druso ${ }^{3}$, e explica-se pela acção de Élio Sejano (initium et causa penes, 4.1.14), cuja influência é perniciosa para o príncipe e para a casa imperial porque ele também tem pretensôes de governo (facinore dominationem raptum ierit, 4.1.1; Tiberium uariis artibus deninxit, artibus uictus est, 4.1.2; hand minus noxiae quotiens parando regno finguntur, 4.1.3; facili Tiberio atque ita prono, 4.2.3). Os comentadores registam "the curious repetition of the thought of retinebat... uerterentur", cujo objectivo é enfatizar o ponto de vista do narrador, ao mesmo tempo que "effects the transition back to the themes of chh. 2-3" (Martin - Woodman 1989 114).

Ainda que poucas, as referências que o narrador faz a Sejano até ao livro IV são significativas por constituírem um exemplo do adensar de indícios que concorrem para a construçáo da

${ }^{1} \mathrm{O}$ conteúdo desta frase é amplificado em 4.4-4.6.

${ }^{2}$ Cf. 4.7.1. Com conjuntivo, é a construção preferida de Tácito: Ernout Thomas 1953 372-373.

${ }^{3}$ E não com a de Germânico: nam Germanici mortem inter prospera ducebat (4.1.1); donec morte Drusi uerterentur (4.7.1); donec Germanicus ac Drusus superfuere (6.51.3).

${ }^{4}$ Causa refere-se também ao assassínio de Druso. 
personagem. Miller 1992146 considera Sejano “a clever and unscrupulous man, whose strength of character probably appealed to Tiberius' difference"5, enquanto para É. Aubrion 1985411 "[i]1 paraît que l'historien déteste particulièrement, parmi les préfets du prétoire, Séjan et Tigellinus. Chacun des deux hommes a droit à un portrait en pied qui est une véritable charge (...) et qui offre à notre analyse l'image de l'anti-héros dans l'oeuvre de Tacite."

A introdução de Sejano na obra faz-se no livro I, onde é identificado como prefeito do pretório que goza de magna apud Tiberium auctoritate (1.24.2). Acompanha Druso na missáo para debelar os motins na Panónia. O seu papel é o de rector iuueni et ceteris periculorum praemiorumque ostentator. No dizer de Miller 1992 146, "Sejanus' job was to keep the soldiers in order, as (...) it was the job of the domus Augusta to rule. He was to show them what they had to lose by disobedience (periculorum) and what they would gain by obedience (praemiorum)." Da expressão rector iuueni ressalta uma nota irónica, uma vez que Sejano será o instigador da morte de Druso.

A característica de Sejano enquanto alguém que compreende a psicologia de Tibério é sublinhada na fórmula peritia morum Tiberii (1.69.5). O prefeito do pretório desempenha ainda um papel de relevo no caso do julgamento de Pisão, acusado da morte de Germânico, porque Sejano evitou que Tibério fosse incriminado: ni elusus a Seiano (...) foret (3.16.1). No mesmo passo, é revelado o seu método de actuação: per uana promissa. Noutro momento do livro III, Tibério exalta Sejano, para quem os senadores propóem uma efígie no teatro de Pompeio: tamquam labore uigilantiaque eius tanta uis unum intra damnum stetisset (3.72.3).

Sejano é a personagem que domina estruturalmente o livro IV, o culminar da aglomeraçáo de indícios textuais, de que resulta a percepçáo cada vez mais nítida da sua presença e personalidade. No entanto, nos livros anteriores, a Sejano não é atribuída qualquer qualidade positiva, e no livro IV apenas há a assinalar o vigor físico

${ }^{5}$ Penso que essa oposição quanto à estrutura psicológica de cada uma das personagens ajuda a compreender a psicologia de Tibério, que de maneira alguma é uma personagem plana: há passos que apontam para ele enquanto tirano sem escrúpulos, mas noutros casos a personagem surge como um espírito frágil que se deixa dominar pelo medo, pela mãe, por Sejano, e que tem na dissimulação o meio mais eficaz para responder às obrigaçóes do estado.

${ }^{6}$ 1.24.2. De notar o agentivo em -tor (cf. Cap. 2, sec. 1). 
e a audácia, "mais il n'est une question pour lui ni d'éloquence, ni de force intellectuelle; on lui dénie même l'habilité politique qui pourrait expliquer son ascension" (Aubrion 1985 413).

É. Aubrion sintetiza o retrato de Sejano ${ }^{7}$ segundo seguintes os tópicos: origem (genitus Vulsiniis patre Seio Strabone equite Romano, 4.1.2), vigor físico ${ }^{8}$ e energia moral (corpus illi laborum tolerans, animus audax, 4.1.3), desenvolvimento das disposiçôes do animus (palam compositus pudor, intus summa apiscendi libido, eiusque causa modo largitio et luxus, saepius industria ac uigilantia, haud minus noxiae quotiens parando regno finguntur, 4.1.3), relaçōes com a sociedade envolvente (Tiberium uariis artibus deuinxit adeo ut obscurum aduersum alios sibi uni incautum intectumque efficeret... ceciditque, 4.1.2).

Nas secçôes seguintes, demonstrarei como estas e outras características do prefeito do pretório dinamizam o seu papel de agente maquinador de intrigas, ávido de poder absoluto, ainda que o capítulo trate igualmente do episódio da acusação de Libão Druso, cujo processo, embora não tenha que ver com Sejano, foi o primeiro caso de uma série de outros que haveriam de minar o estado romano: por isso, não só se constitui como relevante para que a sua narraçáo conheça grande desenvolvimento, como também nele se verificam indícios retóricos que serão utilizados em outras narrativas de processos de acusação (algo que o julgamento de Pisão já revelou).

Quanto à influência de Sejano, ela nota-se em vários casos que serão analisados isoladamente. Por vezes, Sejano não surge como autor das intrigas, mas os seus clientes actuam para poderem chegar a diversas magistraturas e cargos de relevo (aliás, ser amigo de Sejano era ser amigo de Tibério, 6.8.2), ideia particularmente evidente no episódio de Tício Sabino, por exemplo, que configura um caso de eliminação de alguém devido à simulaçáo de amizade íntima. Igualmente relevante é a perseguição de Cremúcio Cordo, que representa uma oposição ligada à liberdade de expressão.

No entanto, não é só na relação de clientelismo que se verifica a influência de Sejano: é por meio da sedução de Lívia Júlia, mulher de Druso, que ele consegue a morte do filho de Tibério,

${ }^{7} \mathrm{O}$ autor estabelece o paralelismo, que aqui omito, com Tigelino. Quanto à conhecida inspiração no Catilina de Salústio, v. Leeman 1963 356-57, Aubrion 1985413 e Martin — Woodman 1989 84-85.

${ }^{8}$ Aubrion 1985 412: "Rien sur le développement des qualités de corpus parce que Tacite ne s'intéresse guère au physique des individus." 
pretendendo depois casar-se com a viúva. Os seus planos, assentes numa esperança que ele cria com ela e que se revelará vã, acabam por náo ter resultados imediatos, mas deles decorre o controlo absoluto da correspondência de Tibério, que Sejano consegue isolar em Cápreas. A tentativa de Sejano obter o poder continua então com a progressiva eliminaçáo dos filhos de Germânico, herdeiros de Tibério, tal como Druso havia sido.

As acções criminosas de Sejano e dos seus cúmplices encontram fundamentos legislativos na lex maiestatis, forma reduzida de maiestas minuta populi Romani: é a lei que condena crimes de traição (e que passa a acompanhar todos os casos: 3.38.1). A sua história, traçada ao longo da obra, tem desenvolvimento especialmente interessante no discurso de Cremúcio Cordo (4.34.2), no qual a personagem diz que os seus crimes não foram cometidos contra a figura do princeps nem contra a sua família, confirmando um alargamento do âmbito da aplicação da lei, que passa a incluir delitos de menor importância.

A denúncia por maiestas desencadeia um complexo processo judicial que leva a grande maioria das vezes à condenação do arguido à morte ${ }^{9}$ (há, porém, casos em que a acusação de maiestas é abandonada ou resulta no degredo). Em muitos desses casos o acusado é subliminarmente exaltado num processo retórico que leva à vitimização da personagem - mesmo quando o réu é culpado, o narrador tende a usar um discurso que o desculpa, sem nunca o condenar (Walker 1952 93, 96-97 e 218-220). Paralelamente, os chamados delatores, indices, ou accusatores são diabolizados pela voz diegética porque desenvolvem uma actividade vergonhosa, como a afirmação genus hominum publico exitio repertum (4.30.3) testemunha ${ }^{10}$. Esse sentimento de admiração pela coragem demonstrada pelo réu e a sua procura de dignidade no último momento da vida, bem como a relevância que se dá à aversão sentida por aqueles que seguem a carreira de acusadores, faz parte do processo de moralização incutida no leitor. $\mathrm{Na}$ perspectiva da trama narrativa, o medo torna-se sentimento generalizado, configurando uma isotopia, enquanto os instigadores dos processos, como que por realizaçáo pessoal, são louvados com prémios (4.30.3).

${ }^{9}$ Walker 1952263 (onze mortes no principado de Tibério) e 264-265 (vinte e uma pessoas condenadas, excluindo mortes, no mesmo período).

${ }^{10}$ Aliás, são os acusadores que prejudicam as leis ao manipulá-las para o mal: 3.25.2. Tibério pensa que os acusadores são protectores do estado: 4.30.2. 
No geral, o narrador omite diversas informaçôes e explicaçôes dos processos de maiestas. Por diversas vezes, não concretiza os motivos em que se baseiam as acusaçôes, quem são as testemunhas de acusação, de defesa, os seus argumentos, quais as provas, ou mesmo que sentença resultou do julgamento. Estas deduçóes são mostradas por R. Rogers 1952 279, que conclui não existir consistência na apresentação dos dados de modo a formarem um padráo fixo, no qual o narrador se baseia para enunciar estes episódios. Tal facto deve-se à busca de uariatio em acontecimentos que, pela recorrência, se tornariam enfadonhos para o leitor ${ }^{11}$. Com efeito, faz parte do estilo de Tácito sublinhar certos aspectos para moldar a expressão da sua mensagem da melhor maneira. De facto, a originalidade da obra reside em não ser sistemática nem obedecer às convençôes pré-estabelecidas ${ }^{12}$.

Ainda segundo R. Rogers, são julgadas por maiestas quase 40 pessoas $^{13}$. Pela sua distribuição ao longo da obra, conclui-se que são os livros IV, VI e XVI aqueles em que mais casos são julgados. Esta disposição corresponde, sensivelmente, aos momentos de maior terror dos principados de Tibério e de $\mathrm{Nero}^{14}$.

No livro IV, o narrador lamenta que a sua obra seja um compilar de ordens cruéis, de acusaçóes contínuas, de falsas amizades, de ruína de inocentes, sendo as causas da morte sempre as mesmas (nos saeua iussa, continuas accusationes, fallaces amicitias, perniciem innocentium et easdem exitii causas coniungimus, 4.33.3). Esta declaração serve de justificação para que a obra apresente episódios que o sujeito da enunciação classifica de obuia rerum similitudine et satietate (4.33.3). Ainda assim, como se verá, a construção retórica do discurso não proporciona uma leitura de enfado, pois que constantes uariationes e pequenos apontamentos patéticos a tornam um acto de deleite estético e interpretativo, ao mesmo tempo que reflectem uma perspectiva ética e moralista, de que esses casos são exempla, devendo extrair-se deles uma lição (é essa, para Tácito, a função da História).

${ }^{11} \mathrm{O}$ narrador mostra consciência disto em 4.33 .3 (cf. Cap. 1, sec. 3).

12 Walker 1952 87-137 dá conta, numa perspectiva literária, mas também histórica, dos diversos casos de maiestas nos Annales.

${ }^{13}$ No seu estudo, Walker 1952 263-269 lista 95 só no principado de Tibério.

${ }^{14}$ No principado de Cláudio não houve julgamentos de maiestas. 


\section{Amizades falsas e perniciosas: Libâo Druso}

O episódio de que Libão Druso é protagonista inicia-se com a indicação temporal de que ele se situa no mesmo plano cronológico da narrativa da história de Germânico, no livro II: sub idem tempus ${ }^{15}$. A preposição sub regendo acusativo denota a ideia de tempo, "suggérant en plus l'entrée dans le repère chronologique" (Touratier 1994 287). O interlúdio na história de Germânico acarreta também uma mudança espacial, pois a acção decorre em Roma, onde o narrador apresenta novas personagens. A principal é o arguido do processo em causa, Marco Escribónio Libão Druso. É relevante analisar o modo como é apresentado o seu nome, partindo da origem familiar: e familia Scriboniorum Libo Drusus. O genitivo de definição em vez do adjectivo apositivo é bastante frequente na prosa de Tácito, característica que a aproxima da poesia ${ }^{16}$. Com esta construçáo, o narrador insere Libão Druso numa grande família de personalidades ilustres e é apresentado como se o nome de família fosse um epíteto. Da apresentação da personagem pela ascendência (expresso como complemento circunstancial de origem), antes mesmo do seu nome (em nominativo), resulta a sugestão da profundidade histórica da personagem, ou seja, o narrador confere à personagem um passado que não é necessariamente desenvolvido no texto, mas aflorado.

A frase com que se apresenta Libão é também a que o coloca vítima de uma denúncia anónima: defertur moliri res nouas. A voz passiva (de defero $^{17}$ ) transmite precisamente uma acção na qual

15 O capítulo 27 do livro II surge com um novo assunto: a acusação, julgamento e morte de Libão Druso (um importante processo de maiestas a que o narrador dá grande atenção por ser um caso singular, mas que terá continuação ao longo dos tempos). A história de Germânico, assim interrompida, será retomada em 2.41.2, já no início do ano 17: Sub idem tempus e familia Scriboniorum Libo Drusus defertur moliri res nouas (2.27.1).

${ }^{16}$ Miller 1992 23, Furneaux 1896 50; valor: Ernout — Thomas 1953 42-43.

${ }_{17} \mathrm{O}$ verbo no presente histórico transporta o leitor para o momento da acção e aproxima-o dela: Touratier 1994 96-99. Furneaux 189655 e 316, e Goodyear 2004265 referem que verbos com sentido de 'acusar' construídos com infinitivo (construção pessoal) são particularmente comuns nos Annales: cf. 3.22.1, 6.19.1, 13.23.1. 
Libão é paciente de uma acusação sem agente activo. Tratando-se aparentemente de uma acusação sem rosto, a revelação do delator, mais à frente, cresce em importância, pois o caso que agora se inicia parece desencadeado por forças ocultas.

No fim desta introdução genérica, o narrador assume a primeira pessoa do singular, que é a expressão da autoridade, ao mesmo tempo que sublinha a importância deste caso: eius negotii initium, ordinem, finem curatius disseram, quia tum primum reperta sunt quae per tot annos rem publicam exedere (2.27.1). A referência a um caso primordial serve de pretexto para um maior desenvolvimento da sua trama, tornando-o exemplar e o modelo de outros que se seguem com tanta frequência que rem publicam exedere. O negotium que se discute é, aparentemente, a delação de maiestas, que tinha já surgido em 1.72.2-74.5, "but we here first find persons entrapped by intimate friends, who keep up private communications with Caesar", como diz Furneaux 1896317.

Depois da introdução, narra-se o episódio propriamente dito:

Firmius Catus senator, ex intima Libonis amicitia, iuuenem inprouidum et facilem inanibus ad Chaldaeorum promissa, magorum sacra, somniorum etiam interpretes impulit, dum proauum Pompeium, amitam Scriboniam, quae quondam Augusti coniunx fuerat, consobrinos Caesares, plenam imaginibus domum ostentat, hortaturque ad luxum et aes alienum, socius libidinum et necessitatum, quo pluribus indiciis inligaret (2.27.2).

O narrador não póe em causa a culpa de Libão Druso, mas acaba por atenuá-la, expondo claramente os motivos que contribuíram para a criação de condiçóes propícias que levam Libão a julgamento. Não se fala de modo claro em golpe de estado $^{18}$ (moliri res nouas), mas apenas no desvio comportamental - e vangloriação pelos antepassados, possível pela linhagem ilustre.

No plano retórico, sobressai a manipulação de Libão levada a cabo por alguém da sua esfera íntima. Neste sentido, é importante relevar a personalidade de Libão, dito iuuenem inprouidum et facilem inanibus. O vocábulo iuuenem tem escopo sobre inprouidum e facilem (este último particularizado por inanibus,

${ }^{18}$ Furneaux $1896316-317$ póe em causa que se trate de maiestas, ao afirmar que "the whole shown to shrink into mere questions of astrology and magic"; cf. Rogers 1952 279, 283-285. 
evidenciando que ele não estava disposto a nada de prejudicial para o Estado), donde resulta uma relaçáo de dependência casual e natural destas qualidades (é inprouidus e facilis inanibus porque iuuenis), mas que pode ser interpretada como um conjunto caracterizador da personagem (é iuuenis, inprouidus e facilis inanibus). A adjectivação que é aposta a este nome, inprouidus e facilis, resulta de uma disposição gradativa das características de Libão, onde o último elemento é o mais negativo, mas, por essa posição, acaba por ser atenuado. Neste contexto, a juventude é sinónimo de falta de maturidade, inclinação para influências externas, sobretudo em oposição à experiência de Fírmio, que, senador, tem mais idade ${ }^{19}$.

O delator, agora identificado (Firmius Catus) depois da omissão do agente da passiva de defero, é amigo íntimo de Libão (ex intima Libonis amicitia), pertencente à classe senatorial (senator), o que torna a armadilha mais torpe. Além de denunciante, Fírmio Cato é instigador dos crimes do amigo: impulit, ostentat e hortatur são verbos que exprimem essa ideia, distribuída por três momentos.

$\mathrm{O}$ primeiro surge sob o domínio semântico de impulit, construído de modo a dar relevo ao movimento ${ }^{20}$, pois acompanham-no complementos introduzidos por ad: Chaldaeorum promissa ${ }^{21}$, magorum sacra ${ }^{22}$, somniorum (...) interpretes $^{23}$. Todos têm a mesma estrutura (um genitivo e o acusativo regido por $a d$, zeugmático nas duas últimas estruturas). Unido assindeticamente, este tricolon forma um conjunto semântico do campo da adivinhação.

O segundo momento é introduzido pela conjunção temporal dum, pelo que a acção é cronologicamente coincidente com a do primeiro momento. No entanto, o tempo verbal é actualizado para o presente do indicativo. Agora a acção é expressa pelo verbo ostento, frequentativo de ostendo, ou seja, repercute-se pelo tempo, indiciando a insistência de Cato em instigar o orgulho

${ }^{19}$ Esta concepção de juventude não é a que domina nos Annales, onde, por exemplo, Germânico é iuuenis, mas com as boas qualidades de um general ou pai de família.

${ }^{20}$ Já subjacente ao significado do verbo: 'empurrar contra ou para, lançar, atirar contra, incitar, provocar, induzir a'.

${ }^{21}$ Os Caldeus - termo que designa alguns povos da Babilónia: Woodman 200452 n.27 — eram os astrólogos: cf. 3.22.1, 6.20.2, 12.22.1, 12.68.3, 14.9.3, 16.14.1. Também são referidos, nos Annales, como mathematici (2.32.3) e periti caelestium (4.58.2).

${ }^{22}$ Especialistas em feitiços e drogas: Furneaux 1896317.

${ }^{23}$ Chamados também coniectores: Furneaux 1896317 e Goodyear 2004269. 
de Libão com a história da sua família. Os complementos são quatro - três em sequência temporal, do mais antigo para os mais novos, culminando numa sintetização: (1) proauum Pompeium, referindo Sexto Pompeio, pai de Pompeia, sua mãe; (2) amitam Scriboniam, a mulher de Pompeio, sobrinha da mulher de Augusto; (3) consobrinos Caesares, pois descendiam da mesma linhagem ${ }^{24}$; (4) plenam imaginibus domum, que sintetiza a importância da família Escribónia (Furneaux 1896 317).

Ligado copulativamente (-que) ao segundo está o terceiro momento, dominado pelo verbo hortor. Daqui, sobressaem dois núcleos: (1) ad luxum et aes alienum e socius libidinum et necessitatum; o homeoteleuto cria uma unidade entre luxum, (aes) alienum, libidinum e necessitatum. As áreas semânticas de cada um dos núcleos são, no primeiro caso, excessos financeiros e, no segundo, morais, sem sinais de especificação de moliri res nouas. A partir da oração quo pluribus indiciis inligaret, concorre-se para a constituição de um processo judicial. Não se especifica nenhum indicium concreto, mas percebe-se, com o verbo inligaret, que Libão Druso caiu numa armadilha e está agora 'amarrado, preso' (OLD s.v. illigo), sem possibilidade de fuga.

A produção de provas, mesmo que fictícias, culmina em 2.28.1: Vt satis testium et qui serui eadem noscerent repperit, aditum ad principem postulat. No entanto, não será o próprio Fírmio Cato a apresentar a acusaçáo, mas uma nova personagem, Flaco Vesculário: demonstrato crimine et reo per Flaccum Vescularium equitem romanum, cui propior cum Tiberio usus erat. Fírmio não só arranjou testemunhas e escravos (aproveitando o facto de Libáo Druso ter caído na emboscada por ele preparada), como escolheu uma pessoa de confiança do imperador para lhe apresentar o caso. É significativa a construçáo sintáctica do sintagma per Flaccum Vescularium equitem romanum: o agente, um ser humano, é considerado instrumento ou meio para que a acçáo expressa pelo verbo tenha sucesso ${ }^{25}$. Reforça-se, como antes (Firmius Catus senator, 2.27.2), a condição social de quem é responsável pela delação e percebe-se que o narrador é um moralista que se manifesta contra a degeneraçáo da sociedade romana ${ }^{26}$, pela tónica que imprime a estes assuntos.

${ }^{24}$ Além disso, o pai de Libão, Marco Druso Libão, foi adoptado por Marco Druso Claudiano, o pai de Lívia Augusta (cf. 5.1).

${ }^{25}$ Allen — Greenough 1903253.

${ }^{26} \mathrm{O}$ aposto de Flaccus Vescularius é o sintagma eques romanus, que designa a classe social ilustre, mas também a origem romana. 
Tibério é a personagem para a qual converge a atenção do narrador ${ }^{27}$, que dá conta da sua vontade e decisão, a partir de 2.28.2: Caesar indicium haud aspernatus congressus abnuit. Tibério impóe que seja Flaco o intermediário das suas conversas com Cato: posse enim eodem Flacco internuntio sermones commeare a personagem Tibério prefere a proximidade de um cavaleiro à de um senador. Esta preferência merece ponderação, pois parece configurar uma tendência para confiar em pessoas de menor importância social (recorde-se que Sejano também é cavaleiro). De facto, um senado demasiado servil (aliás, esta ideia é claramente veiculada na expressão o homines ad seruitutem paratos!, em 3.65.3) não merece confiança.

A análise do interior da personagem de Tibério é bastante evidente no passo que agora transcrevo: atque interim Libonem ornat praetura, conuictibus adhibet, non uultu alienatus, non uerbis commotior (adeo iram condiderat) (2.28.2). Retoma-se a isotopia da dissimulação de Tibério, que aqui surge como alguém que esconde as expressóes do rosto, e fala, como se nada tivesse acontecido, com alguém a quem concede uma pretura e convida para banquetes ${ }^{28}$. O substantivo praetura é, sintacticamente, o instrumento com que Libão é honrado, o que, em conjunto com esses convites para banquetes, não tem de revelar segundas intençôes. No entanto, é o discurso parentético adeo iram condiderat, isolando e resumindo a atitude hipócrita de Tibério, que denuncia a sua maneira de ser, a sua verdadeira natureza, que com estas pistas se vai revelando. Assim acontece com o uso do verbo ornat, cujo sentido de 'honrar (com)' (OLD s.v. orno 6) surge por contiguidade semântica, isto é, por metonímia. Tendo em conta a imagem de um princeps que esconde a ira até a vítima cometer o erro fatal que a conduzirá a uma morte trágica, no contexto presente, o sentido de orno tem uma carga semântica ligada a uma condecoração de fachada que apenas serve para manter as aparências. A construção dos sintagmas descritivos da reacção do imperador (non uultu alienatus, non uerbis commotior) é paralelisticamente perfeita: anáfora de non, que nega duas palavras começadas por $u$ - e com o mesmo número de sílabas (uul-tu, uer-bis). Estrutural e gramaticalmente falando, são dois elementos iguais e simétricos. Esta estratégia retórica cria um

${ }^{27} \mathrm{O}$ foco esteve até aqui em Cato.

${ }^{28}$ Em alternativa, pode pensar-se que o imperador pretendia conhecer bem o arguido nesta "fase de instrução". 
efeito de simultaneidade dos (não) gestos do imperador, ou seja, Tibério manteve-se impassível ${ }^{29}$.

O narrador continua a explorar a simulação de carácter da personagem, na descrição que faz do seu comportamento ao longo deste caso: cunctaque eius dicta factaque, cum $^{30}$ prohibere posset, scire malebat (2.28.2). A colocação de cuncta, dicta e facta no início da frase e por esta ordem dá-lhes especial ênfase do geral para o particular, o poder de Tibério poderia exercer-se sobre todas as acçóes de Libáo, mas preferiu o conhecimento (de todas).

Tal era o comportamento de Tibério até surgir Fulcínio Trião: donec Iunius quidam, temptatus ut infernas umbras carminibus eliceret, ad Fulcinium Trionem indicium detulit (2.28.2). Neste passo, aparecem duas novas personagens, 'um certo Júnio', que se posicionará do lado dos acusadores, e Fulcínio Triáo, que é logo caracterizado pela afirmação celebre inter accusatores Trionis ingenium erat auidumque famae malae (2.28.3) — uma personagem maligna por opção, ou melhor, por desejo (expresso pela construção com genitivo de auidum). Sendo ingenium (Trionis) o sujeito da frase, é sobre ele que se fazem as afirmaçôes: celebre inter accusatores e auidum famae malae, como se o 'talento' tivesse a capacidade psíquica de ser ávido — transporta-se para o 'talento' a personalidade de Triáo, numa construção marcadamente metonímica (hipálage). A personificação do abstracto corporiza o espectro textual, dando-lhe vida e vontade próprias.

Esta personagem perversa acaba por fazer precipitar a acção. A velocidade com que o faz é bem visível na organização sintáctica dos elementos frásicos curtos e com elipse do sujeito. $\mathrm{O}$ advérbio statim e o homeoteleuto reforçam essa velocidade nas acçóes: statim corripit reum, adit consules, cognitionem senatus poscit (2.28.3). A transformação de Libão Druso em acusado está feita, pois ele já é dito reus. A convocação dos senadores é imediata: et uocantur patres, addito consultandum super re magna et atroci. A definição do caso (re) como magna e atrox recorda a sua delicadeza e importância, ao mesmo tempo que sintetiza as informações até aqui fornecidas pelo narrador $^{31}$. Libão Druso, reus antes de o ser, tem o destino traçado.

${ }^{29}$ Provavelmente à espera de apanhar Libão Druso em falso.

30 Sobre o sentido concessivo de cum, v. Allen — Greenough 1903 354-355.

31 Esta estratégia cria consistência na narrativa. Note-se o uso de super (construído com ablativo) com sentido de de: Goodyear 2004272. 
Com a aproximação do julgamento, o narrador acompanha as acçóes de Libão em prol da sua defesa:

Libo interim ueste mutata cum primoribus feminis circumire domos, orare adfinis, nocem aduersum pericula poscere, abnuentibus cunctis, cum diuersa praetenderent, eadem formidine (2.29.1).

A imagem transmitida é a de um homem desesperado, vestido de escuro ${ }^{32}$, que tenta a salvaçáo indo de casa em casa daqueles que lhe eram mais próximos e de pessoas ilustres. Libão tem a companhia de primoribus feminis, o que realça o seu desespero, porque tenta auxílio ${ }^{33}$ recorrendo às influências junto dos conhecidos. Os verbos, em infinitivo histórico ${ }^{34}$, dão vivacidade ao percurso. $\mathrm{O}$ uso de interim $^{35}$ faz com que a acção esteja em sequência paralela à anterior.

A enumeração desses actos é feita de forma variada: ablativo absoluto (ueste mutata), construção paralelística (circumire domos, orare adfinis) e quiástica em relação a ela (uocem aduersum pericula poscere) e novo ablativo absoluto (abnuentibus cunctis), resumindo os resultados da procura, que, mais minuciosa e analítica, concorre para um desfecho sintético e sombrio: ninguém quis defender Libão Druso contra os perigos. A oração temporal-causal explica o fracasso da empresa de Libão: cum diuersa praetenderent, eadem formidine. Todas as justificaçóes se resumem, assim, a uma - o medo. Recorda-se com estas palavras a principal característica da sociedade romana que os Annales descrevem: a servidão, a que todos recorrem por causa do terror instituído pelo comportamento sombrio do princeps e pela multiplicação de delatores.

É ainda de medo que se fala no parágrafo seguinte: die senatus metu et aegritudine fessus (2.29.2). O tom de pesar sente-se na fonética: as vogais altas e fechadas $(i, u, e)$ têm preponderância, bem como as consoantes oclusivas - um ritmo cadenciado, triste e arrastado acompanha o corpo aterrorizado e doente (de

32 A roupa escura era usada pelos acusados em tribunal (cf. Woodman 200453 n.32) e era símbolo de luto. Neste caso, as mulheres que Libáo tem do seu lado são uma espécie de praeficae.

33 Furneaux 1896318 entende que uoces é "an equivalent expression to 'patronos petenti' (...)”; cf. Goodyear 2004273.

${ }^{34}$ Touratier 1994 127: "l'infinitif de narration est l'équivalent d'un imparfait et a donc une valeur purement descriptive"; cf. Touratier 1994153 e 347.

${ }^{35} \mathrm{O}$ advérbio interim surge já em 2.29.1 com o mesmo fim (v. 2.31.1 infra). 
aflição ${ }^{36}$ ) de Libão Druso. A sequência é interrompida com outra, de natureza disjuntiva: siue, ut tradidere quidam ${ }^{37}$, simulato morbo. Finalmente, o réu chega à cúria, apoiado no irmão: lectica delatus ad foris curiae innisusque $e^{38}$ fratri et manus ac supplices uoces ad Tiberium tendens immoto eius uultu excipitur. Os gestos $\left(\right.$ físicos $\left.^{39}\right)$ são ligados por conjunçóes copulativas (-que, et, ac), que representam uma sequencialidade temporal (uns a seguir aos outros), enquanto o particípio presente tendens evidencia, não só a simultaneidade de movimentos, mas também a demora com que são feitos ${ }^{40}$. $\mathrm{O}$ uso de diferentes conjunçôes copulativas tem que ver com os diversos graus de relaçáo semântica que os sintagmas têm entre si: delatus e innisus, delatus-innisus e tendens, manus e uoces encontram-se assim sintacticamente agrupados ${ }^{41}$, sem ambiguidade ${ }^{42}$ e com o reforço da já referida sequencialidade temporal.

$\mathrm{Na}$ relação de tendens com manus e com uoces (pois aquela forma está em zeugma em relação a uoces: Furneaux 1896319 e Goodyear 2004 273), o verbo adquire duplo valor retórico, um próprio ('estender as mãos') e outro metafórico ('estender palavras', equivalente a 'dirigir a palavra'). Também com supplices se observam as expressóes do sentido próprio e metafórico, pelo jogo que se faz entre o concreto e o abstracto: trata-se de uma imagem da atitude de um suplicante, que o estender das mãos cristaliza.

Como resposta a estas súplicas desesperadas, Tibério assume uma atitude de indiferença, mantendo-se em silêncio e sem expressão no rosto: immoto uultu ${ }^{43}$. Insiste-se na ideia de que o imperador continua a esconder o que sente, denunciando um

${ }^{36}$ Como se documenta em Ernout - Meillet 1959 s.v. aeger; cf. morbus (doença do corpo).

${ }^{37}$ Mostra-se que o relato que o narrador apresenta é baseado noutros.

${ }^{38} \mathrm{O}$ particípio innisus construído com dativo é de emprego poético, como avisa Goodyear 2004273.

39 Este excerto exprime não só gestos, mas também a posição do corpo: innisus, tendens.

${ }^{40}$ Concretiza-se a ideia de metu et aegritudine fessus. Com efeito, em tendens os sons ecoam-se a si mesmos (oclusiva+en-). E um modo de demonstrar a dificuldade de movimentos (repetidos porque difíceis).

${ }^{41}[$ [delatus (...) innisusque] (...) et [manus ac (...) uoces] (...) tendens].

${ }^{42}$ A enclítica -que e a conjunção ac reúnem, aqui e em 1.1.2, sintagmas nominais da mesma natureza sintáctica, ao passo que et congrega segmentos frásicos (da mesma natureza sintáctica).

${ }^{43}$ Cf. 2.28.2: non uultu alienatus. 
aumento da tensão dramática que resultará na morte do acusado. Estuda-se uma imagem de imparcialidade e equanimidade, que o imperador mantém no início do julgamento por ele presidido: mox libellos et auctores ${ }^{44}$ recitat Caesar ita moderans ${ }^{45}$ ne lenire neue asperare crimina uideretur (2.29.2). A continuidade temporal é transmitida pelo advérbio mox. A leitura do processo é feita de forma imparcial, como compete a um juiz que já antes se manteve impassível às súplicas por parte do réu. De facto, é assinalada a moderação da personagem (moderans). Os objectivos são também explicitados: ne lenire neue asperare crimina uideretur, em que crimina recorda e sintetiza as transgressóes anteriormente discriminadas ${ }^{46}$.

A narração do julgamento é feita de modo bastante sintética, como se verifica pela ausência de complementos circunstanciais e de coloraçáo figurativa, como se da acta do julgamento se tratasse. Quase sem transição, o narrador transmite a identidade dos acusadores e os problemas de serem tantos:

Accesserant praeter Trionem et Catum accusatores Fonteius Agrippa et $C$. Vibius, certabantque cui ius perorandi in reum daretur, donec Vibius, quia nec ipsi inter se concederent et Libo sine patrono introisset, singillatim se crimina obiecturum professus, protulit libellos uaecordes (2.30.1).

Juntam-se mais dois acusadores contra o arguido, vincando ainda mais o facto de Libão se encontrar sozinho (sine patrono; cf. 2.29.1). Não é dito nada de concreto acerca das duas novas personagens, ao contrário, por exemplo, da anterior caracterização do ingenium de Triáo (em 2.28.3). De Fonteio Agripa, sabe-se

44 Woodman 200453 n.33 clarifica que "the 'authorities' are those individuals who had endorsed the prosecution".

${ }^{4}$ A interpretação de moderans não é consensual. Por exemplo: Furneaux 1896 319: "restraining himself', so moderante 1.15.[1]" (cf. 2.70.4 e 6.2.6); Woodman 2004 53: "with such control"; Wuilleumier 1978a 95: "ton mesuré"; Grimal 1993 72: "veillant bien”; Goodyear 2004274 defende a interpretação "directing himself, following a (middle) curse" e sustenta a tese em 1.15.1, 6.2.5 e 6.10.3.

${ }^{46}$ Os crimina são deduzidos de 2.27 , onde se diz que o réu foi impelido para maus costumes: consulta de promessas dos Caldeus, de ritos dos mágicos, de intérpretes de sonhos, vida de luxo, acumulação de dívidas, luxúria, etc. Lembre-se mais uma vez que, apesar de no início desse capítulo se falar em moliri res nouas, não há referência concreta a acções que sugiram efectivamente um movimento revolucionário. 
muito pouco, e pelo que é dito somente em 2.86.1. É um dos ilustres a oferecer a filha para o lugar de vestal, mas esta é preterida em favor da filha de Comício Poliáo. De Gaio Víbio, ainda que aqui não se fale do seu carácter, é mais tarde afirmado que se trata de alguém com poucos escrúpulos (4.29.4), que foi procônsul da Hispânia Ulterior (4.13.2) e foi condenado pela sua uis publica (4.28.1-4.30.1).

Há, porém, um lado irónico no aumento de acusadores: são tantos que náo conseguem chegar a acordo sobre qual seria o primeiro a discursar. A querela culmina na resoluçáo introduzida pela conjunção donec, e é uma das novas personagens que vai expor o caso pormenorizadamente ${ }^{47}$ — a oraçáo causal com conjuntivo quia nec ipsi inter se concederent exprime uma causa irreal, por isso é de prever que os acusadores nunca ficariam todos de acordo - , aproveitando o facto de o réu não ter defesa.

Expostos os factos, chega a fase de argumentação, que o narrador define com manifesto desprezo: protulit libellos uaecordes. $\mathrm{O}$ adjectivo uaecors (usado, apenas aqui, em referência a coisas: Gerber - Greef - John 1962 s.v. vecors) mostra a qualidade das provas produzidas e cria, juntamente com o exemplo que lhe segue, um efeito extremamente irónico: tantos acusadores contra um homem sem defesa e não se esforçam por produzir provas consistentes, mas apenas uaecordes! Daqui se depreende que este é um julgamento de fachada, em que, sem apelo, o réu é condenado. Esta tese ganha força quando o narrador exemplifica o tipo de argumentos utilizados pela acusação: adeo ut consultauerit Libo an habiturus foret opes quis uiam Appiam Brundisium usque pecunia operiret (2.30.1).

O vocabulário escolhido ilustra o ambiente de tribunal: accusatores, ius perorand $i^{48}$, reus, patronus, crimina, libelli. Ainda assim, o caso não é descrito com todos os pormenores, havendo muita informação para se subentender. As acusaçôes lançadas contra Libão Druso são sempre dadas como vazias de sentido ${ }^{49}$ : inerant et alia huiusce modi stolida uana, si mollius acciperes, miseranda (2.30.2). O narrador não se inibe de caracterizar os argumentos de acusação como sendo todos stolida, uana, ou miseranda.

${ }^{47} \mathrm{O}$ que sucede apesar do que se disse sobre a fama de Cato e de Trião (cf. 2.28.2: celebre inter accusatores Trionis ingenium erat auidumque famae malae).

${ }^{48} \mathrm{O}$ ius perorandi é "the privilege (...) of making the formal oration": Furneaux 1896319.

${ }^{49} \mathrm{Ou}$ mesmo falsas: OLD s.v. uanus 3. 
Contudo, o narrador, ou porque quer provar a estupidez, ou porque considera tratar-se de um argumento de relevo (o que justifica o emprego de tamen adversativo: Furneaux 1896 319), concretiza uma das acusaçôes: uni tamen libello manu Libonis nominibus Caesarum aut senatorum additas atrocis uel occultas notas accusator arguebat (2.30.2). Esta frase tem dividido os comentadores, principalmente no que concerne ao segmento uni tamen libello, pois há editores que consideram que deveria ser uno (...) libello, colocando a expressáo em ablativo, em vez de dativo. Com efeito, as duas liçôes são aceitáveis. Enquanto Furneaux 1896319 exclui a correcção para $u n o^{50}$, sugerindo que se subentenda inesse (que estava já na oração anterior), a maioria dos tradutores verteram como se fosse ablativo, à excepção de $\mathrm{P}$. Grimal e A. J. Church e W. J. Brodribb ${ }^{51}$.

Realização estilística é o uso que se faz das conjunçôes disjuntivas em Caesarum aut senatorum e atrocis uel occultas. Não se trata apenas de simples uariatio: é um jogo sintáctico no âmbito do quiasmo, pelos respectivos referentes estarem no início e no fim das estruturas disjuntivas: nominibus Caesarum aut senatorum (...) atrocis uel occultas notas. ${ }^{52}$

O sujeito e o verbo estão colocados no fim para efeitos expressivos. Assim, chama-se a atenção para o facto de tudo o que foi referido fazer parte da argumentação do advogado de acusação. $\mathrm{O}$ arguido defende-se:

negante reo adgnoscentis seruos per tormenta interrogari placuit. et quia uetere senatus consulto quaestio in caput domini prohibebatur, callidus et noui iuris repertor Tiberius mancipari singulos actori publico iubet, scilicet ut in Libonem ex seruis saluo senatus consulto quaereretur (2.30.3).

Os escravos servem de testemunha (retomando-se o que havia ficado assegurado em 2.28.1: ut satis testium et qui serui eadem

50 "The correction 'uno' still leaves no less awkwardness in the juxtaposition of two different ablatives, 'libello' and 'manu'."

${ }^{51}$ Grimal 1993 72: "L'accusateur produisait comme charge, pourtant, une liste, écrite de la main de Libo..."; Church — Brodribb 2006 69: "there was one paper in Libo's handwriting...”.

${ }^{52}$ Furneaux 1896319 entende atrocis uel occultas notas como "deadly, or at least mysterious symbols", o que faz perder o efeito que referi. Goodyear 2004276 segue Gerber — Greef — John 1962 s.v. vel, onde este emprego da conjunção surge como distributivo. 
noscerent repperit). Estes poderiam incriminar o senhor, mas a legislação romana impedia que assim fosse, quando está em causa a vida do dominus. Não obstante, os testemunhos dos escravos passam a ser válidos porque estes deixam de ser escravos de Libão Druso, numa estratégia que faz de Tibério callidus et noui iuris repertor: o novo direito já não infringe o antigo decreto do senado ${ }^{53}$. Ao julgar Tibério pela sua artimanha, o narrador diminui a culpa do réu. A explicação que concretiza a mancipação dos escravos reforça a ironia precisamente porque nem precisava de ser dada. O tom irónico projecta ainda um desalento, como a quantidade de sibilantes e de vogais interiores fechadas (nomeadamente $u$ ) da última oração demonstra, daí resultando um arrastar da frase: in Libonem ex seruis salüo senatus consulto quaereretur.

Chegado o julgamento a este ponto, Libão Druso desiste e não vê outra alternativa a não ser pedir a suspensão do processo. Em 2.30.4, expressam-se desistência e desespero ${ }^{54}$ : ob quae posterum diem reus petiuit domumque digressus extremas preces P. Quirinio propinquo suo ad principem mandauit. Uma nova personagem é o veículo da súplica final (extremas por ser a última tentativa e não poder voltar a fazer nenhuma, mas também como sinal de desespero, pois o resultado do julgamento está cada vez mais claro). O ritmo é indelevelmente marcado pela sonoridade das consoantes oclusivas e das vogais anteriores fechadas $e$ e $i$. A frase apresenta-se como elemento de rápida transição entre o julgamento e o espaço da casa de Libão, prenunciado por domum digressus. A resposta dada ao último apelo do arguido é que o peça ao senado: Responsum est ut senatum rogaret (2.31.1). A expressão impessoal (que refere Tibério) retoma o anonimato do início do episódio (defertur). A acção precipita-se em tragédia:

cingebatur interim milite domus, strepebant etiam in uestibulo ut audiri, ut aspici possent, cum Libo ipsis quas in nouissimam uoluptatem adhibuerat epulis excruciatus uocare percussorem, prensare seruorum dextras, inserere gladium (2.31.1).

A narração é cheia de movimento: os soldados cercam a casa ${ }^{55}$ enquanto tais acontecimentos se davam, como o emprego de

${ }^{53}$ No julgamento de Silano, Tibério também mandou vender os escravos ao actor publicus para os torturar e usar seu testemunho (3.67.3).

${ }^{54}$ Goodyear 2004 278: "[Libo,] by asking at this stage for adjournment, virtually admitted his case lost".

55 A presença dos soldados servia apenas para intimidar Libão Druso: Goodyear 2004278. 
interim sugere ${ }^{56}$. Em termos gramaticais, é notável a alteração do agente singular (miles com sentido colectivo) para sujeito plural: strepebant (etiam) in uestibulo — os militares eram muitos e faziam muito barulho: ao elemento visual, junta-se o auditivo - e esta cumplicidade de sentidos surge ainda na expressão ut audiri, ut aspici possent. É certo que esta anáfora de ut confere ao texto "rhetorical emphasis" (Furneaux 1896 320), mas eu entendo esta repetição (note-se que audiri e aspici têm o mesmo número de sílabas e começam por $a$ e acabam em $i$ ) principalmente como o ecoar dos soldados que estáo por todo o lado — e fazem questão de se mostrar.

O único adjectivo ligado a Libão é excruciatus, da família de crux (elemento material), mas também 'tormenta' (OLD 2b e 3). Este estado de espírito ${ }^{57}$ é motivado pelo banquete que oferecia, como demonstração do seu último prazer (nouissima uoluptas). A partir de cum, a personagem toma novo ânimo, as suas acções surgem em infinitivo histórico, "frequent in lively descriptions"58: uocare percussorem, prensare seruorum dextras, inserere gladium. Sequências em assíndeto, constituídas por verbos e nomes em acusativo de estrutura paralelística, mostram a rapidez com que acontecem - Libão encontra-se no início do fim, sendo também por isso notável a atmosfera trágica (percussor e gladium, a arma do suicídio).

A reacção de Libão alerta os escravos:

atque illis, dum trepidant, dum refugiunt, euertentibus adpositum cum mensa lumen, feralibus iam sibi tenebris duos ictus in uiscera derexit (2.31.2).

${ }^{56} \mathrm{O}$ advérbio interim é preferido para concatenar as acçóes, pelo tempo, que é a categoria narrativa que hierarquiza os acontecimentos.

${ }^{57}$ Goodyear 2004278 rejeita que ipsis (...) epulis seja temporal — ao contrário de Furneaux 1896320 — e que "Libo's torment occasioned only by his fear on the advent of the soldiers. So to interpret is to set the word-order at naught, to ignore the contrast between uoluptatem and excruciatus, and to miss the possibility that both physical symptoms (indigestion, nausea, or whatever), the meal was their immediate cause, but it would not so have acted without a psycological cause, his acute distress."

${ }^{58}$ Furneaux 1896 55. Casos como este, em que o infinitivo histórico é introduzido por cum, surgem em 2.40.1, 4.50.6 e 6.44.3. Outras conjunções surgem em 6.19.4 (ubi) e 13.57 .6 (donec). Goodyear 2004278 salienta o vigor e a variedade da construção. 
O desespero toma conta de todos à medida que o fim se aproxima. As movimentaçóes são rápidas, representadas pelos presentes do indicativo e pela repetição anafórica da conjunção dum: exprime-se uma acção in fieri, enquanto derexit é pretérito perfeito, marcando uma acção pontual, rápida, prenunciada pela conotação dramática de feralibus iam sibi tenebris.

É de noite que ocorrem as acçôes a seguir narradas. A luz em cima da mesa, que é derrubada, criando um ambiente ainda mais soturno - feralis porque não voltará a ver a luz (cf. Goodyear 2004278 e Furneaux 1896 321) — mostra-o. Com dois golpes nas entranhas, dados por uma arma já conhecida (2.31.1), mas agora não referida - é assim que morre e familia Scriboniorum Libo Drusus, depois de ter sido acusado de moliri res nouas (2.27.1).

Morto o senhor da casa, a agitação aumenta nesse espaço: ad gemitum conlabentis adcurrere liberti, et caede uisa miles abstitit (2.31.2). Parece confirmar-se que não estava mais ninguém com Libáo, a não ser os escravos e os soldados ${ }^{59}$ que agora se retiram. O substantivo caedes $^{60}$ designa aqui um suicídio, o que pode indicar que Libáo apenas usou a sua mão para se matar, mas quem verdadeiramente o matou foi outra pessoa: o seu amigo íntimo Fírmio Cato (ex intima Libonis amicitia, 2.27.2). Estes pequenos apontamentos tornam o acontecimento ainda mais vergonhoso.

Os libertos fazem o movimento contrário (adcurrere) daquele feito antes pelos serui (refugiunt): é o grito do que cai que desencadeia esse movimento, bem como o das tropas (que o vêem morto e se retiram). O complemento circunstancial de lugar para onde (ad gemitum ${ }^{61}$ ), que acompanha o verbo adcurro, reforça o movimento de confluência para junto do corpo, quando o prevérbio ad- já denota esse movimento (OLD s.v. ad-).

Do cenário trágico da morte, regressa-se, em 2.31.3, ao ambiente da cúria; é que no dia seguinte ao suicídio, o julgamento continua: accusatio tamen apud patres adseueratione eadem peracta, iurauitque Tiberius petiturum se uitam quamuis nocenti, nisi uoluntariam mortem properauisset. A acusação continua a ser conduzida, mas náo se refere por quem (porque o verbo está sem agente da passiva); no entanto, não é preciso que o narrador

${ }^{59}$ Volta-se ao singular colectivo, depois de uma variaçáo pelo plural.

${ }^{60}$ Que significa 'assassínio, morte' (OLD 1b).

${ }^{61}$ Acorrem para junto do grito, que é soltado por um conlabens, criando-se assim uma relação semântica no âmbito da metonímia. 
denomine os acusadores, porque já se sabe quem são. A atitude de Tibério, que lamenta que Libão Druso tenha apressado a morte, parece fazer sobressair a sua qualidade de misericordioso (uma das características que marcam a primeira parte do seu principado), depois de se ter comportado com grande frieza. De facto, o imperador jura que iria ilibar o acusado, tal como aconteceu com Clutório Prisco (3.49-51).

O capítulo 32 fecha o episódio, sintetizando-se as decisóes tomadas que resultaram da acusação de Libão Druso. A morte de uma pessoa traz condecoraçóes políticas para outras ${ }^{62}$. Não só se manifestam desta maneira as pretensóes políticas dos acusadores, como o prémio que acabam por ter, existindo outros passos na obra em que se verifica a mesma recompensa, como se tivesse sido prestado um serviço à pátria. Os acusadores de Pisão, por exemplo, também recebem cargos políticos e magistraturas em troca da vingança da morte de Germânico. No caso de Tício Sabino, também foi a vontade de ascender politicamente que levou a que senadores o tivessem acusado. Quanto aos acusadores de Libão Druso, foi dividida por eles a fortuna do réu e concedida uma pretura aos que eram senadores: Bona inter accusatores diuiduntur, et praeturae extra ordinem datae iis qui senatorii ordinis erant (2.32.1).

Depois disto, outras decisôes foram sendo tomadas tendo em vista uma espécie de condenação da memória de Libão Druso:

tunc Cotta Messalinus, ne imago Libonis exequias posterorum comitaretur, censuit, Cn. Lentulus, ne quis Scribonius congnomentum Drusi adsumeret. supplicationum dies Pomponii Flacci sententia constituti, dona Ioui, Marti, Concordiae, utque iduum Septembrium dies, quo se Libo interfecerat, dies festus haberetur, L. Piso et Gallus Asinius et Papius Mutilus et L. Apronius decreuere (2.32.1-2).

Este tipo de acontecimentos é visto pelo narrador como um uetus malum: quorum auctoritates adulationesque rettuli ut sciretur uetus id in re publica malum (2.32.2). Com efeito, estas palavras

${ }^{62}$ Rogers 1952 285: “Tacitus has minimized the gravity of Libo's activities with consummate rhetorical skill, by dwelling upon the trivialities, which the prosecutors may well have discoursed upon in order to prejudice the Court, but which Tacitus can dismiss as venial folly, and by passing very lightly and quickly over the only evidence which he mentions pointing toward a conspiracy to assassinate Tiberius, his heirs and other nobles." 
retomam a ideia de que a delação começava a ser uma profissão - eius negotii initium, ordinem, finem curatius disseram, quia tum primum reperta sunt quae per tot annos rem publicam exedere (2.27.1) - e que os acusadores são um genus hominum publico exitio repertum que vêem o seu trabalho recompensado: per praemia eliciebantur (4.30.3). O narrador vai, assim, denunciando uma actividade torpe que começava a ser cada vez mais praticada, a ponto de 'corroer' (exedere) o estado e ter como fim a morte de muitas pessoas (publico exitio). Fulcínio Triáo acaba por representar exemplarmente o papel de acusador profissional, cujo fim confirma a ideia de torpeza e abjecção da sua actividade (v. 6.4.1 e 6.38.2-3). 


\section{Da morte de Druso ao isolamento de Tibério}

Nero Cláudio Druso é o filho de Tibério e de Vipsânia, nascido por volta de 13 a.C.: no ano 4, com a adopção de Tibério por Augusto, passou a chamar-se Júlio César Druso. Em Tácito, é apenas nomeado Druso. Foi cunhado de Germânico, e seu irmáo, quando este foi adoptado por Tibério (1.3.5). A sua esposa era Lívia Júlia - que alguns autores (mas nunca Tácito) tratam por Livila - , união que lhe foi fatal.

A comparação da aristeia de Druso (concentrada principalmente no livro III) com a de Germânico (no livro II) é frequente nos Annales, como é sublinhado pelos comentadores Woodman - Martin 1996 3-7: ambos são filhos de Tibério, vítimas de alegado envenenamento (2.69.3 e 4.8.1). A morte de Druso leva à conclusão do paralelismo inevitável das suas carreiras. Decorre um período de três anos entre os primeiros consulados de cada um (Germânico em 12 e Druso em 15), o tempo que os separa em idade (cf. 3.56.4): "This pattern of employment and promotion was to continue to the end of their respective lives" (Woodman - Martin 1996 3). No livro I, Druso controla o motim na Panónia (16-30) e Germânico na Germânia (31-51), e quando os episódios terminam os dois são louvados no senado por Tibério (1.52.1-3; cf. Cap. 2, sec. 3). No ano 17, voltam a ser referidos em conjunto. Apesar das sugestóes de que Tibério favorecia Druso - algo desmentido em 3.56.3 - e de que a casa imperial estava dividida, o narrador dá conta do facto de os dois irmãos serem os melhores amigos (3.43.5-6). No ano 18, Germânico cumpre consulado juntamente com Tibério (2.53.1), e em 21 é a vez de Druso ser honrado dessa maneira (3.31.1). No livro II, as aventuras de Germânico no estrangeiro (53-61) são seguidas pelas de Druso (62-63); quando os episódios terminam, é decretada uma ouatio no senado para os dois (2.64.1), o que constitui um paralelismo com a narrativa do livro I. A ouatio não acontece porque Germânico morre entretanto. "The transference of all hope to Drusus alone was swiftly recognised" (Woodman — Martin 1996 4).

Como foi salientado, a narraçáo da morte de Druso marca 
estruturalmente a mudança da essência do governo de Tibério para uma natureza mais sinistra. Antes de estudar o papel da esposa de Druso no seu assassínio, proponho uma análise do episódio da morte do filho de Tibério (4.7-8).

Durante os primeiros anos do principado de Tibério, era o medo de Druso que impedia Sejano de actuar criminosamente a fim de obter o poder: quia Seianus incipiente adhuc potentia bonis consiliis notescere nolebat, et ultor metuebatur (4.7.1). De facto, percebe-se desde logo que se o poder ${ }^{63}$ é incipiens é porque vai ser aumentado (desvendando-se assim os resultados mais tarde obtidos por Sejano). Por outro lado, o medo (metuebatur) é um sentimento que Sejano partilha com Tibério ${ }^{64}$ (formidatus, cf. formido, 1.7.6). É notável que a governação positiva de Tibério co-ocorra com a de Sejano, outro ponto que têm em comum (decorrente do receio que sentiam). A forma ultor (relacionada com o verbo ulciscor), associada a Druso, traz algumas dúvidas interpretativas porque não se explicita porque é ele um vingador, mas tal característica pode ter que ver com a protecção da domus Caesaris, que Sejano planeia atacar ${ }^{65}$.

A relação de Sejano com Druso é antiga. Aquele acompanhou o filho de Tibério na expedição à Panónia (para debelar os motins das legióes) como rector (1.24.2). No entanto, esta não é uma relaçáo saudável nem amistosa, tanto que haviam já surgido disputas entre ambos. $\mathrm{O}$ excesso de poder e influência de Sejano parece explicar essa relação que conheceu momentos de verdadeiro melindre, como aquele em que chegou a haver uma agressão (4.3.2).

É em focalização interna em Sejano que a voz diegética justifica o ódio da parte de Druso: non occultus odii set crebro querens incolumi filio adiutorem imperii alium uocari (4.7.2). $\mathrm{O}$ pronome alium sugere a violência da distinção entre Druso e outro, revelando-se uma grande indignação (a ponto de alguns editores pontuarem a frase com um ponto de exclamação). $\mathrm{O}$ discurso indirecto livre continua com o desvendar dos planos de

${ }^{63} \mathrm{O}$ poder é expresso por potentia, "actual power" (Martin — Woodman 1989 80). Há diversos passos que sublinham a relação de Sejano com o poder, referido como auctoritas, dominatio, dominor, regnum, etc.

${ }^{64} 4.1 .2$ e 4.11 .2 realçam as semelhanças entre Tibério e Sejano.

${ }^{65}$ Esta explicação só é possível se se entender esta porção de texto como focalizada em Sejano (cf. Martin — Woodman 1989 114). Yardley 2008140 traduz como focalizada em Druso. 
Sejano, em modo sentencioso: primas dominandi spes in arduo: ubi sis ingressus, adesse studia et ministros. Pela focalização em Sejano, o narrador recupera e reúne acontecimentos anteriormente dispersos: extructa iam sponte praefecti castra (cf. 4.2.1); datos in manum milites (4.2.2); cerni effigiem eius in monimentis Cn. Pompei (3.72.3); communis illi cum familia Drusorum fore nepotes (3.29.4 e 4.39.2). Assim, o poder de Sejano actua sobre os militares, o povo e a família imperial. Será, por isso, impossível implorar-lhe $e^{66}$ modéstia, como sugere a expressão irónica ut contentus esset e o parágrafo seguinte ilustra, acentuado pela expressão em lítotes: neque raro neque apud paucos talia iaciebat (4.7.3).

Este é, pois, um testemunho da falta de modéstia de Sejano (virtude a que este queria estar ligado, como se lê em 4.39 .2 e 4.40.5) e da sua altivez, características que, aliadas a spes e nimia fortuna, configuram claramente a hybris da personagem. $\mathrm{Na}$ mesma frase, é incluída uma informação de grande relevo, que apenas provoca um aumento da tensão dramática por representar o aproximar da katastrophê de Druso: et secreta quoque eius corrupta uxore prodebatur (4.7.3, a que voltarei em seguida).

Com efeito, segue-se a narração da morte de Druso, com grande velocidade discursiva, pois que se limita à declaração:

Igitur Seianus maturandum ratus deligit uenenum quo paulatim inrepente fortuitus morbus adsimularetur. id Druso datum per Lygdum spadonem, ut octo post annos cognitum est (4.8.1).

Na diegese, não se afirma que Druso morre do envenenamento, deduzindo-se essa conclusão do contexto seguinte:

ceterum Tiberius per omnis ualetudinis eius dies, nullo metu an ut firmitudinem animi ostentaret, etiam defuncto necdum sepulto, curiam ingressus est (4.8.2).

O assassínio foi perpetrado por um eunuco, Ligdo ${ }^{67}$, com quem - diziam os rumores (4.10.2) — Sejano tinha relaçóes amorosas. O meio escolhido para matar Druso foi o veneno, permitindo dissimular as causas da morte, aparentando ter-se tratado de uma doença. Pode, por isso, fazer-se um paralelo com a morte de Germânico, na medida em que foi também uma

${ }^{66}$ Em 4.41.1 e 4.39.2, Sejano surge ligado a deprecatur e precatum.

${ }^{67}$ Sobre as inquirições que ocorreram passados oito anos, v. 4.11.2. 
personagem menor a administrar o veneno, a mando de alguém mais poderoso ${ }^{68}$, e depois da morte os sinais de envenenamento não eram nítidos à vista de todos.

O foco narrativo reajustou-se nestes parágrafos: centrou-se em Sejano (igitur Seianus) e agora em Tibério (ceterum Tiberius), de quem o narrador regista a reacção à morte do filho (processo retórico também verificado na descrição da morte de Agripa Póstumo). Curiosamente, omite-se a reacção de Sejano, deixando a reflexão ao cuidado de quem lê. Tibério, que antes demonstrava medo de Druso, durante a sua doença não deixa transparecer esse sentimento: nullo metu an ut firmitudinem animi ostentaret (4.8.2). A disjuntiva an liga dois sintagmas gramaticalmente equivalentes, mas com construção diferente (uariatio): ablativo e oração final. Ostento é um verbo que descreve uma projecção exterior, por isso náo quer dizer que o imperador tenha deixado de temer o filho, mas, como sugerem os comentadores, o contraste nullo metufirmitudinem animi "seems to be an anticipation of Tib[erius]' alleged involvement in Drusus' death, which T[acitus] mentions but rejects at 10.2-11.3 below" (Martin — Woodman 1989 116).

A ida de Tibério ao senado constitui uma cena patética que o narrador menoriza ao denunciar o vazio das palavras do imperador:

ac si modum orationi posuisset, misericordia sui gloriaque animos audientium impleuerat: ad uana et totiens inrisa reuolutus, de reddenda re publica utque consules seu quis alius regimen susciperent, uero quoque et honesto fidem dempsit (4.9.1).

$\mathrm{Na}$ cúria, Tibério havia confiado aos senadores a guarda dos filhos de Germânico, antes da responsabilidade de Druso, a quem foi pedido que tratasse deles, como se fossem seus (4.8.3-5).

Depois de narrar a morte de Druso, o sujeito do enunciado faz um interessante excurso onde desmistifica um rumor corrente na época (4.10.1-11.3) e que, de novo, denuncia a dificuldade do historiador em interpretar os dados a que tem acesso, pela desvirtuação que os boatos criam nos factos. Semelhante observação havia sido feita a propósito da morte de Germânico (3.19.2).

${ }^{68}$ Ligdo assume o papel de Martina, tal como Sejano assume o papel de Pisão e de Plancina. 
Convém ainda realçar a importância da esposa de Druso, que até ao livro IV é uma personagem inteiramente ancilar na economia da narrativa dos Annales. Lívia Júlia ${ }^{69}$ assume, a partir desse momento, um papel de grande relevo como coadjuvante de Sejano na eliminação de Druso. Apesar de figurante, as referências a Lívia nos três primeiros livros dinamizam um processo de acumulação de indícios que, enquadrando-a na família imperial de modo particularmente ilustre, dramatizam as acçóes nefastas de que ela se tornará agente.

Quando é referida, é a sua condição de mulher de Druso a que tem maior preponderância ${ }^{70}$, sendo ainda designada como soror Germanici $^{71}$ — a sua genealogia revela-se por dedução: ela é filha de Antónia e de Nero Cláudio Druso ${ }^{72}$; neta de Marco António e de Octávia (irmã de Augusto), pelo lado da mãe, e neta de Tibério Cláudio Nero e de Lívia (depois esposa de Augusto), por parte do pai. Lívia Júlia é, assim, sobrinha-neta (e neta por afinidade) de Augusto. Estas relaçóes familiares, apenas sugeridas até ao livro IV, hão-de ser explicitamente recordadas num momento de maior tensão narrativa.

No livro III, há uma breve alusão a Lívia, numa fala de Druso, que, enquanto cônsul, discursa no senado durante o debate acerca da proposta de proibição de os magistrados (encarregados de governar as províncias) viajarem com as mulheres ${ }^{73}$ :

addiditpauca Drusus de matrimonio suo; nam principibus adeunda saepius longinqua imperii. quoties diuum Augustum in Occidentem atque Orientem meauisse comite Liuia! se quoque in Illyricum

69 Para evitar confusão com a viúva de Augusto, a esposa de Druso será nomeada Lívia Júlia.

${ }^{70}$ Em 2.43.6, ela é uxor Drusi, em 2.81.1, nupta Drusi, e em 3.34.6 referida por Druso como uxore carissima. Esta ligação é novamente lembrada em 4.3.3, 4.40.2 e 4.40.4 (as duas últimas vezes numa carta de Tibério a Sejano). Uma vez que Druso é filho de Tibério com Vipsânia, Lívia está ligada à estirpe de Agripa e (pelo lado do pai e do sogro) à família Cláudia. O facto de ter filhos de Druso (2.84.1 e 3.34.6) parece encerrar uma maior responsabilidade relativamente ao marido.

71 2.84.1. Lívia é, por isso, irmã de Cláudio: cf. 4.3.3.

${ }^{72} \mathrm{O}$ irmão de Tibério, no qual o povo romano tinha esperança de restauraçáo da liberdade, como se viu a propósito de Germânico no Cap. 2, sec. 3.

${ }^{73}$ A discussão ocorre de 3.33 .1 a 3.35 .3 e tem origem numa questão levantada por Cecina Severo. Cf. Traub 1953 e Marshall 1975 11-18. 
profectum et, si ita conducat, alias ad gentis iturum, haud semper aeque animo si ab uxore carissima et tot communium liberorum parente diuelleretur (3.34.6).

O passo é manifestamente irónico (Sinclair 1990 244-245): a uxor carissima de quem Druso não se quer afastar, mãe dos seus filhos ${ }^{74}$, e exemplo da pertinência que a companhia das mulheres representa para os maridos em missão nas províncias distantes, é também a principal cúmplice de Sejano na sua morte.

Outros aspectos relevantes emergem desta intervenção em discurso indirecto livre ${ }^{75}$. Inserido no contexto de uma discussão no senado $^{76}$, e ainda que defenda o contrário, o discurso prova como a proximidade das mulheres com o poder político traz resultados nefastos à governação. Com o exemplo de Lívia e Augusto, o narrador, pela voz de Druso, está a evocar uma mulher que pode ter assassinado o marido; ao referir Lívia Júlia nomeia outra mulher que será co-responsável pela morte do marido daqui parece decorrer a confirmação da culpa que anteriormente tinha sido baseada em rumores (quidam scelus uxoris suspectabant, 1.5.1): Lívia Augusta apressou a morte de Augusto para que o poder fosse atribuído a Tibério. Trata-se de um forte indício de que, tal como Lívia Augusta, Lívia Júlia foi efectivamente responsável pela morte do marido ${ }^{77}$.

Semelhante paralelismo - que o conhecimento a priori do destino das personagens Augusto e Druso proporciona enfatiza a ironia da cena e cria uma atmosfera trágica em torno da personagem Druso, cujo destino concorre para a katastrophê.

${ }^{74} \mathrm{~V}$. Woodman - Martin 1996308 sobre liberi communes, considerado um "emotional appeal to the ancient notion that children 'cement' a marriage".

75 São aspectos negligenciados por Santoro L'hoir 2006 118-124, que analisa toda a proposta à luz de Tito Lívio. De resto, a referência a Lívia é ignorada pelos índices das ediçóes e das traduçóes dos Annales, bem como por Fabia 1964, apesar da sua relevância para a caracterização da personagem.

${ }^{76} \mathrm{O}$ discurso dialoga, de um modo geral, com as palavras proferidas anteriormente: e.g. alias ad gentis responde a ne feminae in socios aut gentis externas traherentur (3.33.2). Este eco, com a variante alias/externas, torna operativa a aproximação que a seguir farei com Germânico.

${ }^{77}$ Furneaux 1896186 esclarece que em 1.5.1, tal como em 4.10.2 e 6.33.1, scelus é aplicado especificamente a veneno, ideia secundada por Goodyear 1972 131, que ressalva o facto de "here and at 4.10.2 the context as much as anything lends the word this implication, if it has it, and at 6.33.1 it is not absolutely clear that poisoning is meant." 
Outro elemento que confirma a aproximação da catástrofe é a "não" recordação de Germânico. Com efeito, a omissão de Germânico e Agripina como exemplo de casais que viviam juntos em províncias ${ }^{78}$, bem como a utilização de elementos textuais que recordam a morte daquele, legitimam essa comparação. Assim, a expressão alias gentis reflecte externas inter gentis de 2.73.2, onde se diz que Germânico, tal como Alexandre, morreu entre povos estrangeiros sob as insídias dos seus (suorum insidiis externas inter gentis occidisse). Além disso, a própria evocação da esposa carissima e dos communes liberi remete para a cena da morte de Germânico, que lembra precisamente a sua coniux, os seis liberi $(2.71 .4)^{79}$.

Deste modo, considero o quadro que o narrador apresenta em 3.34.6, mais do que irónico, uma resposta à dúvida levantada quanto ao papel de Lívia Augusta na morte de Augusto (cuja responsabilidade, divulgada por diversos rumores, havia ficado na incerteza: cf. Cap. 2, sec. 1), um exemplo da hamartia de Druso, e mais uma prova da deinôsis característica do estilo de Tácito (Cousin 1951).

É neste contexto que, a partir do livro IV, Lívia Júlia assume um relevo maior, saindo da sombra do marido. Como se disse, o início deste livro, que coincide com o nono ano do governo de Tibério (4.1.1), traz algumas alteraçóes do foco narrativo e da semântica textual, concretizada numa degradação da personalidade de Tibério e no seu isolamento em Cápreas ${ }^{80}$.

$\mathrm{O}$ narrador não tem dúvidas quanto à ambição governativa de Sejano e ao seu modo de actuação para chegar ao poder; este depara, porém, com um grande obstáculo aos seus planos. Por muito próximo que estivesse de Tibério, e por muita influência que sobre ele exercesse, a casa imperial estava plena, ou seja, não havia falta de sucessores: Ceterum plena Caesarum domus, iuuenis filius, nepotes adulti moram cupitis adferebant (4.3.1) ${ }^{81}$. A noção

${ }^{78}$ Quando eles haviam sido descritos na obra como um casal feliz, com filhos. O desempenho de Agripina e de Germânico foi decisivo para o fim dos motins das legióes; de facto, como se viu, ao longo da obra, Germânico e Druso são muitas vezes comparados, assim como Agripina é comparada a Lívia Júlia.

${ }^{79}$ Estes últimos surgem em discurso directo como uxor e communes liberi em 2.72.1 (cf. Cap. 2, sec. 4).

${ }^{80}$ Aliás, a oração cum repente turbare fortuna coepit (4.1.1) demonstra essa alteração.

${ }^{81}$ A vontade de Sejano ascender ao poder é um desejo, cupitum, tema a que voltarei. 
plena domus ecoa integra domus de 1.3.1, referindo-se aí o narrador ao tempo de Augusto. O plano de Sejano é eliminar todos os possíveis sucessores de Tibério: et quia ui tot simul corripere intutum, dolus interualla scelerum poscebat. placuit tamen occultior uia et a Druso incipere (4.3.1). Esta frase resume a actuação de Sejano (corripio, dolus, scelus) e caracteriza-o psicologicamente como alguém que age com cuidado, ponderando os riscos da sua acçáo (intutus, posceo). O leitor reconhece ainda nesta declaração acontecimentos passados, pois também Lívia Augusta havia eliminado a descendência do marido para que o filho lhe sucedesse. $\mathrm{O}$ passo recorre, aliás, a vocabulário usado no livro I: dolus (1.3.3, sobre a morte de Lúcio e Gaio), scelus (1.5.1, a propósito do estado de saúde de Augusto) e occultus (1.33.1, acerca dos odia que Augusta e Tibério sentem por Germânico).

A decisão para começar por Druso é justificada por uma ira recente que surgiu entre ambos (in quem recenti ira ferebatur, 4.3.2), narrando-se um episódio que ilustra esse desentendimento: nam Drusus impatiens aemuli et animo commotior orto forte iurgio intenderat Seiano manus et contra tendentis os uerberauerat (4.3.2). O narrador associa a este motivo o início da relação de Sejano com Lívia, como a seguir se verá. Não se explica a origem da ira, mas, pelo que se testemunha em 4.7.1, Druso estava ressentido (aemulus) pela preponderância política que Sejano estava a alcançar. Algumas pistas vocabulares sugerem que Tibério atribuía poderes a Sejano, tal como Augusto havia feito com ele e com Agripa. É sobretudo a este último que a narrativa aproxima Sejano, operacionalizando as próprias personagens essa mesma comparação (cf. 4.40.7).

O envolvimento de Lívia Júlia nos seus projectos é narrado em 4.3.3:

igitur cuncta temptanti promptissimum uisum ad uxorem eius Liuiam conuertere, quae soror Germanici, formae initio aetatis indecorae, mox pulchritudine praecellebat. hanc ut amore incensus adulterio pellexit, et postquam primi flagitii potitus est (nequefemina amissa pudicitia alia abnuerit), ad coniugii spem, consortium regni et necem mariti impulit. atque illa, cui auunculus Augustus, socer Tiberius, ex Druso liberi, seque ac maiores et posteros municipali adultero foedabat ut pro honestis et praesentibus flagitiosa et incerta expectaret.

Os planos de Sejano são urdidos cuidadosamente, fruto de um trabalho intelectual que considera todas as possibilidades (cuncta); 
o exercício mental é insinuado pelo verbo tempto, enquanto uideor denota o resultado desse pensamento - acção acabada, expressa em perfeito, contrastando com o prolongamento no tempo que se exprime pelo particípio presente de um verbo iterativo de pensamento (temptanti).

A reflexão de Sejano resulta em movimento (metafórico), que se manifesta no verbo conuerto e no seu complemento constituído por ad com acusativo. É para Lívia que Sejano e o foco narrativo se viram. Aposto a uxorem Liuiam, surge outro laço familiar de relevo: soror Germanici. Trata-se de uma referência que repete 2.84.1, cuja aproximaçáo torna operativa a comparação que a seguir se faz com Agripina. Na mesma medida, a recordaçáo das relações que Lívia mantém com a casa imperial contribui para o adensar de indícios que tornam mais vis os actos criminosos que se avizinham.

Então, e pela primeira vez, o narrador presta atenção ao aspecto físico de Lívia. O verbo praecello ecoa 2.43.6 (cf. Sinclair 1990243 n.13), onde o narrador diz que Agripina excedia Lívia em número de filhos. Esta aproximação traz outro elemento à comparação entre as duas personagens: Lívia é mais bonita, mas Agripina é o paradigma de pudicícia que Lívia perverte ${ }^{82}-$ amissa pudicitia.

A frase tem dois referentes temporais, um antes (initio) e um depois (mox), abrindo a oposição passado-presente, a seguir desenvolvida, juntamente com o contraste feio-belo. $\mathrm{O}$ jogo entre as duas dicotomias, que se revezam mutuamente, resulta na sugestão de que a beleza exterior não tem reflexo no interior (indecorus designa uma realidade desagradável à vista e pulchritudo uma beleza externa ${ }^{83}$ ).

A Sejano continua a ser dado um papel activo, sendo sujeito de verbos de movimento (pellexit ${ }^{84}$ e impulit), e uma actuação sob disfarce ( $u t$, 'como se' ${ }^{85}$ ). Por seu lado, Lívia é referida com o pronome hanc; sobre ela recai a acção de Sejano, que a força ao adultério. Por ter Lívia conseguido o primeiro flagitium, vai-se construindo um discurso de semântica causal, porque, se este é o primeiro, quer dizer que vai haver mais. De facto, a personagem Lívia tem uma relação frequente com corrupção, crimes e ultrajes:

${ }^{82}$ Sinclair 1990 243-245 estabelece a comparação do corpo de Agripina com o de Lívia Júlia.

${ }^{83}$ Cf. OLD s.v. indecorus e pulchritudo.

${ }^{84}$ É notável o ressoar de 1.2.1, em que pellicio se refere a Augusto.

85 Também relacionado com a capacidade de raciocínio, de maquinação. 
flagitiosa (4.3.4), corrupta uxore (4.7.3), corrupta ad scelus (4.10.2), flagitiis (6.2.1), adulterium (6.29.4) ${ }^{86}$.

A lição ensaiada pelo narrador é neque femina amissa pudicitia alia [flagitia] abnuerit, em que femina pode significar 'a mulher' (ou seja, Lívia) ou 'uma mulher' (no sentido impessoal). As opiniôes dos comentadores divergem nesta interpretação. R. Martin defende que se trata de generalização (sem apresentar argumentos) e A. J. Woodman que se refere a Lívia, argumentando que "T[acitus] could [not] have written so counter-factual a generalisation as the statement that a woman, once seduced, was unlikely to reject 'other things', esp[ecially] when the alia in question include necem mariti." ${ }^{\prime 7}$ No entanto, penso que o passo deve ser interpretado como generalizante e sentencioso (assim o defende R. Martin), e náo apenas referente a Lívia. Por outro lado, alia deve relacionar-se com flagitia, e não deve ser visto como forma impessoal com o sentido de 'outras coisas'. Com efeito, até aqui Lívia não teve qualquer papel activo em tomadas de posição, tendo sido constantemente empurrada ${ }^{88}$, pelo que não seria de esperar a sua ligação a um verbo de pensamento como abnuo. Só assim a afirmação se enquadraria no estilo sentencioso de Tácito, o que P. Sinclair 19953 e 34 demonstrou.

A reprovação deste comportamento manifesta-se na nomeação explícita dos laços familiares que Lívia mantém com Augusto (auunculus), Tibério (socer) e Druso (ex Drusi liberi). A enumeração, indo do mais velho para o mais novo, culmina numa generalização sugestiva das proporções da mancha da vergonha que ela lança sobre a família: seque ac maiores et postremos. De novo, é a ironia que caracteriza Lívia. Ela, que sempre foi empurrada para os flagitia, trá-los agora para si, para os antepassados, e para os vindouros.

${ }^{86}$ Cf. ainda infra para flagitante em 4.39.1.

${ }^{87}$ Martin — Woodman 1989 93. Às observaçôes do comentador, que nota a focalização narrativa em Sejano ("perhaps representing Sejanus' contemptuous view of her"), e aproxima este passo de 12.42.2 (onde se alude a Agripina Menor), eu acrescentaria que a perda de pudicícia especificamente relacionada com Lívia serviria para acentuar o contraste entre ela e Agripina.

${ }^{88}$ Metáfora para 'seduzida'. Recorde-se ainda que a personagem tem vindo a ser referida por meio de pronomes, sem que se sublinhe a sua característica de 'esposa', como noutras ocasiôes. Deve ainda notar-se que A. J. Woodman terá mudado de opiniấo relativamente à sua posição, uma vez que traduz, em Woodman 2004 123: "a female was unlikely to reject other things". Grimal 1993155 traduz "une femme qui a perdu son honneur ne saurait plus rien refuser". 
Com a estirpe de Lívia contrasta municipali adultero naturalmente, Sejano ${ }^{89}$. Na frase seguinte, o narrador traça o carácter da personagem com mais pormenor, explicando o motivo do comportamento indecoroso: ut pro honestis et praesentibus flagitiosa et incerta expectaret. A oposição presente-passado transita, pela fórmula seque ac maiores et postremos, para um contraste presente-futuro (praesentibus vs expectaret), ou seja, entre o honos e os flagitia. Daqui resulta que o presente tem uma relação com honos e praesens ${ }^{90}$, e o futuro com flagitia e incerta. Lívia, em face destas opçóes, escolhe, sob uma esperança ${ }^{91}$ vazia, os flagitia em vez das honras.

A manipulação de Lívia Júlia culmina na carta (codicilli) que Sejano escreve a Tibério, onde, já depois da morte de Druso, a pede em casamento (4.39.1). Nesse momento, Sejano é caracterizado como nimia fortuna socors e muliebri insuper cupidine incensus. Sejano dá um passo em falso, confiado na fortuna. A sorte e a esperança são características desta personagem e têm vindo a ser analisadas como exemplos de hybris ${ }^{92}$. A segunda expressáo repercute ut amore incensus de 4.3.3, do mesmo modo que promissum matrimonium responde a 4.3.5. Estas formas de memorando asseguram ao leitor a continuidade lógica da narrativa e acentuam, neste caso, o arrebatamento amoroso, meditado, de Sejano.

Lívia, anteriormente instada a cometer adultério e seduzida por meio de promessas, reivindica agora de Sejano o cumprimento de uma delas (4.3.3) — o casamento, demonstrando arbítrio próprio $^{93}$, e que interiorizou esses juramentos, durante a prossecução dos flagitia; aliás, a forma flagitante ressoa flagitia,

${ }^{89}$ A prova de que esta relação não pode ser consumada está ligada à isotopia da esperança, como se verá.

${ }^{90} \mathrm{Ou}$ seja, 'segurança' (OLD 8), em contraste com incerta. Cf. Furneaux 1896494.

${ }^{91}$ Relaciona-se também com Lívia a isotopia da esperança, frequentes vezes ligada a Sejano.

${ }^{92}$ Sinclair 1990 250. Também em 3.39.4 se fala de esperança excessiva; cf. 4.7.2: primas dominandi spes in arduo: ubi sis ingressus, adesse studia et ministros.

${ }^{93}$ Ainda que Sinclair 1990243 defenda que "Livia is never developed into a fully rounded character and is given no positive traits", o domínio da razão que começa a revelar e a caracterização como carissima (em 3.34.6) parecem negar esta afirmação. 
com que está etimologicamente relacionada. Trata-se, pois, de uma abdicação voluntária dos valores morais romanos ${ }^{94}$.

A carta retoma elementos textuais anteriores e cria novas questóes respondidas posteriormente. $\mathrm{O}$ seu início constitui uma captatio beneuolentiae evidente e sublinha a atitude de modéstia e submissáo de Sejano relativamente ao imperador:

beneuolentia patris Augusti et mox plurimis Tiberii iudiciis ita insueuisse ut spes uotaque sua non prius ad deos quam ad principum auris conferret. neque fulgorem honorum umquam precatum: excubias ac labores ut unum e militibus pro incolumitate imperatoris malle (4.39.2).

É este o tom geral da carta. Sejano lembra a sua dedicação a Tibério, exaltando-o, a ele e ao pai, pondo o bem-estar do príncipe em primeiro lugar e recordando o que é mais belo (pulcherrimum), acreditar-se digno de uma ligação familiar com César (coniunctione Caesaris dignus, 4.39.2). Foi este laço de parentesco, criado pelo casamento de uma filha de Sejano com o filho de Cláudio (3.29.4 e 4.7.2), que criou nele a esperança de ambicionar algo mais (hinc initium spei). $\mathrm{Na}$ argumentação, volta a nomear Augusto e o exemplo que foi este ter pensado em cavaleiros romanos para casar a filha (in conlocanda filia non nibil etiam de equitibus Romanis consultauisse, 4.39.3). Indirectamente, o emissor assume-se cavaleiro (algo que o leitor já sabe), mas mesmo assim oferece-se como pretendente de Lívia: si maritus Liuiae quaereretur, haberet in animo amicum sola necessitudinis gloria usurum (4.39.3). Depois de uma declaração irónica ${ }^{95}$, verifica-se uma alteração semântica da narrativa: do geral (equites) o discurso progride para o particular, centrando-se em Sejano $\left(\right.$ amicus $\left.^{6}\right)$, que lembra agora a sua disponibilidade para tomar o lugar de Druso, assegurando que vai continuar com as mesmas responsabilidades (non enim exuere imposita munia, 4.39.4).

A atitude de modéstia de alguém que age como um soldado

${ }^{94}$ Sinclair 1990254 e 256 faz uma comparação com o modelo de Lucrécia (cf. Martin — Woodman 1989 93).

95 Acentuada pela preocupação que a seguir expressa relativamente aos filhos de Lívia (liberorum causa): se ela não tem marido e se os filhos estão órfã̃os é porque Sejano, com a ajuda dela, mandou matar Druso.

${ }^{96}$ É de realçar a auto-caracterização de um funcionário do Estado como amigo do imperador. Só essa condição lhe valerá influência tal que vai conseguir afastar Tibério de Roma. Cf. 6.8.2: ut quisque Seiano intimis ita ad Caesaris amicitiam ualidus. 
e cuja primeira preocupação é o bem-estar do príncipe ecoa na expressão de satisfação que Sejano afirma ter por defender a casa imperial dos ataques de Agripina. Esta é outra referência ao plano do ministro de Tibério que terá como consequência a destruição da casa de Germânico ${ }^{97}$.

A terminar, uma confissão resume a exaltação do príncipe: nam sibi multum superque uitae fore, quod tali cum principe expleuisset (4.39.4), reafirmando a honra que será para Sejano viver junto de um homem como Tibério, ligado a ele por laços familiares (necessitudo).

A resposta de Tibério à carta de Sejano (4.40) está dividida em três partes. As duas primeiras (de ad ea a adiunxit e de ceteris a coniugio) surgem em oratio obliqua, a terceira em oratio recta. A propósito desta mudança discursiva, Sinclair comenta: "How seriously Tiberius regards this matter and what an open wound it has left in him can be sensed from the rhetorical crescendo toward which the letter drives." 98 De facto, trata-se de um passo extenso em que o imperador, ao rejeitar ceder Lívia para casamento com Sejano, argumenta cuidadosamente a sua posição ${ }^{99}$, sendo possível verificar na resposta de Tibério um espelhar do pedido de Sejano:

Ad ea Tiberius laudata pietate Seiani suisque in eum beneficiis modice percursis, cum tempus tamquam ad integram consultationem petiuisset, adiunxit: ceteris mortalibus in eo stare consilia quid sibi conducere putent; principum diuersam esse sortem quibus praecipua rerum ad famam derigenda. ideo se non illuc decurrere, quod promptum rescriptu, posse ipsam Liuiam statuere, nubendum post Drusum an in penatibus isdem tolerandum haberet; esse illi matrem et auiam, propiora consilia (4.40.1-2).

A primeira parte compreende a reacção sintética a todos os louvores e beneficia feitos por Sejano ${ }^{100}$ a seu favor, enquadrando-se

${ }^{97}$ 4.39.4: firmari domum aduersum iniquas Agrippinae offensiones. Cf. 4.12.2. Já antes (2.84.2) se havia expressado a preocupação com o enfraquecimento da casa de Germânico.

${ }^{98}$ Sinclair 1990 252; cf. Furneaux 189672.

${ }^{99}$ Expressa de modo imediato, sem ocultação nem dissimulação.

${ }^{100}$ A expressão laudata pietate constitui uma "dramatic irony" porque "the reader knows that Sejanus' request has nothing to do with pietas": Martin Woodman 1989 195. Beneficia responde às afirmaçóes de Sejano como spes uotaque sua non prius ad deos quam ad principum auris conferret; excubias ac labores (...) pro incolumitate imperatoris malle, em 4.39.2. 
na personalidade de Tibério (caracterizada pela moderatio) através da fórmula modice percursis. A segunda parte inicia-se com a distinção entre os consilia dos homens comuns e a sorte dos príncipes, cuja preocupação maior tem de ser a fama, 'opinião pública' (Furneaux 1896 537). Por isso (ideo), daí não decorre a decisão de remeter para Lívia a escolha de voltar a casar ou continuar viúva (nubendum post Drusum an in penatibus isdem tolerandum haberet ${ }^{101}$ ), segundo os conselhos da mãe (Antónia) e da avó (Lívia Augusta), sendo elas conselheiras mais adequadas (propiora consilia).

Depois desta introdução, Tibério começa a responder às principais questóes de Sejano:

simplicius acturum, de inimicitiis primum Agrippinae, quas longe acrius arsuras si matrimonium Liniae uelut in partis domum Caesarum distraxisset. sic quoque erumpere aemulationem feminarum, eaque discordia nepotes suos conuelli: quid si intendatur certamen tali coniugio? (4.40.3).

A metáfora do fogo (arsuras), presente já em incensus (4.3.3 e 4.39.1), nega a ideia de Sejano, que defendia que a sua presença iria proteger a casa imperial dos ataques de Agripina (4.39.4). Tibério não pretende criar facçóes dentro da família, revelando preocupação com a aemulatio, a discordia e o certamen que poderiam criar cisóes entre as mulheres (Lívia e Agripina) e os seus netos ${ }^{102}$.

Depois da interrogaçáo, o discurso muda para oratio recta, que começa com um "exordium in reported discourse, breaking by intensity of the emotion into appeal and argumentation" ${ }^{103}$ :

falleris enim, Seiane, si te mansurum in eodem ordine putas, et Liuiam, quae G. Caesari, mox Druso nupta fuerit, ea mente acturam ut cum equite Romano senescat (4.40.4).

${ }^{101}$ Para o verbo habeo com gerúndio ou gerundivo, v. OLD 17a.

${ }^{102}$ É evidente que Tibério, na sua resposta, usa algumas palavras de Sejano, subvertendo-lhes o sentido (v. infra). Por exemplo, as construçóes tali coniugio e e coniunctione tali (4.40.6) remetem para tali cum principe: cf. Martin Woodman 1989197.

${ }^{103}$ Syme 1958 317. Ao dirigir-se a Sejano pelo nome, Tibério imprime um cunho emocional ao discurso. 
Tibério responde em pormenor ao pedido de casamento com Lívia, sublinhando a classe social de Sejano (eodem ordine, equite Romano, e a seguir: locum, equestre fastigium, equite Romano), de modo a explicar os motivos por que recusa esta união, pretendendo com isso desenganá-lo quanto à possibilidade do casamento. De facto, Tibério pensa que Lívia, tendo sido casada com membros da casa imperial como Gaio César e Druso, não aceitará envelhecer junto de um cavaleiro:

ego ut sinam, credisne passuros qui fratrem eius, qui patrem maioresque nostros in summis imperiis uidere? uis tu quidem istum intra locum sistere: sed illi magistratus et primores, qui te inuitum perrumpunt omnibusque de rebus consulunt, excessisse iam pridem equestre fastigium longeque antisse patris mei amicitias non occulti ferunt perque inuidiam tui me quoque incusant. at enim Augustus filiam suam equiti Romano tradere meditatus est (4.40.4-5).

Nesse âmbito, o contraste entre Sejano e as personalidades nomeadas por Tibério é significativo, pois exprime de forma velada que há muitos que são superiores a Sejano, em classe e em qualidade (Gaio César, Druso, magistratus et primores, Gaio Proculeio, Marco Agripa):

mirum hercule, si cum in omnis curas distraheretur immensumque attolli prouideret quem coniunctione tali super alios extulisset, $C$. Proculeium et quosdam in sermonibus habuit insigni tranquillitate uitae, nullis rei publicae negotiis permixtos. sed si dubitatione Augusti mouemur, quanto ualidius est quod Marco Agrippae, mox mihi conlocauit? atque ego haec pro amicitia non occultaui: ceterum neque tuis neque Liuiae destinatis aduersabor. (4.40.6).

Ironicamente, Tibério reverte o pensamento de Lívia, que se sabe querer mesmo casar-se com Sejano (4.39.1), e que náo tem quaisquer preocupaçóes com os antepassados: seque ac maiores et posteros (...) foedabat (4.3.4). Esse aspecto opóe Tibério a Lívia, pois ele diz ter em atençáo os antepassados e a opinião pública:

praecipua rerum ad famam derigenda (4.40.1), credisne passuros qui fratrem eius, qui patrem maioresque nostros in summis imperiis uidere? (4.40.4), excessisse iam pridem equestre fastigium longeque antisse patris mei amicitias non occulti ferunt perque inuidiam tui me quoque incusant (4.40.5). 
A isotopia do excesso, suscitador da hybris, manifesta-se nesse extrapolar dos limites sociais. Assim, Sejano engana-se (fallo) se pensa que irá manter-se (maneo) na mesma ordem, o mesmo erro que cometeu ao dirigir-se, nimia fortuna socors (4.39.1), a Tibério para pedir Lívia em casamento.

No fim da carta, Sejano volta a ser louvado como no início; Tibério promete uma relação que vai colocar o ministro em igualdade com ele:

ipse quid intra animum uolutauerim, quibus adhuc necessitudinibus immiscere te mihi parem, omittam ad praesens referre: id tantum aperiam, nibil esse tam excelsum quod non uirtutes istae tuusque in me animus mereantur, datoque tempore uel in senatu uel in contione non reticebo (4.40.7).

É visível na resposta de Tibério o eco das palavras que Sejano empregou na carta enviada ao imperador. Assim, verifica-se uma referência de Tibério ao facto de Augusto ter ponderado dar a filha em casamento a um cavaleiro ${ }^{104}$, ao estado de espírito e à relação de amizade que liga Sejano a Tibério ${ }^{105}$, bem como o laço familiar que o casamento criaria entre ambos ${ }^{106}$. Da recusa da permissão em casar com Lívia resulta o plano de Sejano em afastar Tibério de Roma - primeiro para a Campânia e depois para Cápreas, num movimento de evidente isolamento. A retirada do imperador garantirá a Sejano cinco anos de supremacia (4.57.1), naquilo que parecia ser a preparação do seu reinado (4.1.3).

Depois deste episódio, sabe-se que Lívia Júlia continuará a ser cúmplice de Sejano. Através de Júlia, filha desta, todos os passos de Druso, filho de Germânico, são controlados, o que garantirá a Sejano a queda daquele que também estava na linha de sucessão ${ }^{107}$. Os flagitia continuam, assim, a ser a principal característica de

${ }^{104}$ Nos exemplos: Augustum in conlocanda filia non nibil etiam de equitibus Romanis consultauisse (4.39.3) vs Augustus filiam suam equiti Romano tradere meditatus est; quanto ualidius est quod Marco Agrippae, mox mihi conlocauit? (4.40.6).

105 Nos exemplos: haberet in animo amicum (4.39.3) vs pro amicitia non occultaui; intra animum uolutauerim; uirtutes istae tuusque in me animus mereantur (4.40.7).

106 Nos exemplos: sola necessitudinis gloria usurum (4.39.3) vs adhuc necessitudinibus immiscere (4.40.7).

107 Será o irmão de Druso, Calígula, aquele que assumirá o poder depois da morte de Tibério. 
Lívia (cf. 6.2.1 e, sobre o adulterium com Mamerco Escauro, 6.29.4) ${ }^{108}$, pois, como já se sabe, neque femina amissa pudicitia alia abnuerit.

${ }^{108}$ Não nos chegou a porção dos Annales que narrava a morte de Lívia Júlia (v. Sinclair 1990 253-254). 


\section{Ataque e destruiçáo da casa de Germânico}

A morte de Druso suscita no senado e no povo romano a esperança da reabilitação da casa de Germânico. É um sentimento que se afigurará vão, mercê da actuaçáo insidiosa de Sejano. Com efeito, o povo sempre havia preferido Germânico a Druso preferência proporcionalmente oposta ao tratamento que Tibério dava aos irmãos:

Ceterum laudante flium pro rostris Tiberio senatus populusque habitum ac uoces dolentum simulatione magis quam libens induebat, domumque Germanici reuirescere occulti laetabantur (4.12.1).

Verifica-se, assim, uma encenação de sentimentos, suportada pela antonímia semântica da isotopia aparência-realidade, representada nos ideais dicotómicos opostos tristeza-alegria e oculto-visível: habitum, magis quam libens, simulatione, induebat, occulti; dolentum, laetabantur.

Neste cenário, também Agripina alimenta esperanças, que mais não fazem do que acelerar a ruína da casa de Germânico: quod principium fauoris et mater Agrippina spem male tegens perniciem adcelerauere $(4.12 .1)^{109}$. Sejano é o responsável por esta ruína (pernicies):

nam Seianus ubi uidet mortem Drusi inultam interfectoribus, sine maerore publico esse, ferox scelerum et, quia prima prouenerant, uolutare secum quonam modo Germanici liberos peruerteret, quorum non dubia successio (4.12.2).

Vendo o crime sem vingança (inultam interfectoribus ${ }^{10}$ ) e apercebendo-se de que não houve luto público ${ }^{111}$, Sejano sente-se impune e arrisca a sorte em crimes ainda maiores ${ }^{112}$. Que o seu

${ }^{109}$ Cf. sed populo tali in tempore id quoque dolorem tulit, tamquam auctus liberis Drusus domum Germanici magis urgeret (2.84.2).

${ }^{110} \mathrm{O}$ plural inclui Ligdo, Sejano e os cúmplices Lívia Júlia e Eudemo.

${ }^{111}$ Ao contrário do que aconteceu com Germânico, em que o luto do povo foi espontâneo (2.82.3) e cuja morte foi vingada (Cap. 2, sec. 4).

${ }^{112}$ Cf. nimia fortuna socors (4.39.1). 
objectivo último é suceder a Tibério fica claro da declaração da urgência em começar a actuar depressa sobre os filhos de Germânico (non dubia successio). De novo - e tal como em 4.3.1, quia ui tot simul corripere intutum dolus interualla scelerum poscebat —, a prudência impede-o de atentar contra todos ao mesmo tempo: neque spargi uenenum in tres poterat, egregia custodum fide et pudicitia Agrippinae impenetrabili (4.12.2). As referências à egregia custodum fides e pudicitia impenetrabilis de Agripina servem de contraste ao modo como Sejano pode actuar contra Druso: o seu amicus Ligdo traiu a sua fides e a sua esposa perdeu a pudicitia, de que Sejano se aproveitou. Assim, por oposição a Lívia Júlia, pudicitia impenetrabilis configura também uma metáfora de carácter marcadamente sexual.

Sejano move-se num cenário propício à prossecução dos seus planos, estimulando para isso o ódio antigo de Augusta por Agripina, utilizando como meio a cumplicidade recente de Lívia Júlia:

igitur contumaciam eius insectari, uetus Augustae odium, recentem Liuiae conscientiam exagitare, ut superbam fecunditate, subnixam popularibus studiis inhiare dominationi apud Caesarem arguerent (4.12.3).

A oposição uetus-recens exprime a acção criminosa gradual de Sejano, que pretende alertar a consciência de Tibério para o potencial perigo de Agripina e da sua prole. Assim, a soberba devido à fecundidade, $\mathrm{o}$ apoio do povo e a avidez de dominação ${ }^{113}$ deveriam despertar em Tibério motivos para eliminar Agripina e os filhos (representados metonimicamente por fecunditas).

$\mathrm{O}$ sucesso da empresa de Sejano vai-se manifestando progressivamente. É representativo o exemplo do episódio em que Tibério se revolta com os votos que sacerdotes ofereceram a Nero e a Druso ${ }^{114}$. Ofendido, Tibério expóe o seu mal-estar, adensando a sua relação conflituosa com a nora:

${ }^{113}$ A ironia em inhiare dominationi é evidente, pois Sejano é, mais do que qualquer outra personagem, aquele que mais interesse tem na governação. $\mathrm{O}$ mesmo tema é tratado em 1.69.4, pelo que, ao ser retomado, apenas revela um aproveitamento por parte de Sejano.

114 A dedicação desses votos é feita non tam caritate iuuenum quam adulatione, quae moribus corruptis perinde anceps, si nulla et ubi nimia est (4.17.1). 
nam Tiberius haud umquam domui Germanici mitis, tum uero aequari adulescentes senectae suae impatienter indoluit accitosque pontifices percontatus est num id precibus Agrippinae aut minis tribuissent. et illi quidem, quamquam abnuerent, modice perstricti (4.17.2).

Tibério parece ter assimilado as críticas que Augusta e Lívia Júlia foram tecendo sobre Agripina, pois nestas palavras o imperador revela ter consciência dos supostos planos que levariam os filhos de Germânico ao poder.

\subsection{A perseguiçấo de Tício Sabino}

O episódio da acusação lançada contra Tício Sabino, de que resulta a sua morte (4.68-70), configura um exemplo de como o narrador entende a fragilidade humana. Em termos estruturais, constitui o caso mais importante na perseguição de inocentes, envolvidos em processos de maiestas decorrentes de falsas amizades: "L'exécution de Titius Sabinus (...) marque une progression dans l'horreur qu'inspirent les affaires de majesté" (Devillers 1994 55). Pela forma como o discurso se constrói, "[n] o episode in Tacitus is more effective emotionally. (...) At the end of a series of more or less detailed episodes comes one which in its vividness and horror distils the emotional content of all the others" (Walker 1952 105).

A personagem Tício Sabino havia sido apresentada na narrativa juntamente com Gaio Sílio: no ano 24, os dois eram acusados (adgreditur, 4.18.1) por causa da amizade de Germânico (amicitia Germanici perniciosa utrique, 4.18.1). O caso de Tício Sabino foi entretanto protelado (dilato ad tempus Sabino, 4.19.1) e, no início do ano 28, é narrada a sua história. Os acontecimentos que sustentam a acusação surgem em analepse (4.68.2-4.70.4), quebrando a linearidade da representação discursiva temporal. $\mathrm{O}$ estudo que agora se apresenta segue, em alguns aspectos, o artigo de P. L. Corrigan 1993, mas inverte essa análise para o âmbito da tragédia e das isotopias que têm vindo a ser realçadas.

Corrigan divide o seu estudo em quatro secçóes: a queda de Sabino, o culto a Jano nas Calendas de Janeiro (na civilizaçáo romana), o dia 1 de Janeiro de 28 em Tácito, e o episódio no livro IV dos Annales. Na primeira parte, dá relevo aos pormenores da narrativa - classe social da personagem, motivo da prisão, a relação que mantinha com a casa de Germânico (em público e 
em privado), o que fazia dele o último dos antigos amigos da família. Por isso, o narrador afirma que é apud bonos laudatus et grauis iniquis (4.68.1), separando em facçôes os heróis e os seus adversários na história, ideia que o quiasmo realça.

Ao facto de Sabino ter sido preso no primeiro dia do ano é dado grande relevo durante o episódio:

Iunio Silano et Silio Nerua consulibus, anni principium (4.68.1), anni kalendis Ianuariis (4.70.1), sic inchoari annum, has Seiano uictimas cadere (4.70.1), diem uacuum poena, noui magistratus (4.70.3).

Tal acontecimento levanta um problema de natureza religiosa, uma vez que é possível considerar o episódio como um protesto contra a dessacralização da data ${ }^{115}$.

A acusação é conduzida por quatro ex-pretores de carreira, levados pelo desejo do consulado (cupido consulatus: activa-se assim a isotopia da vontade de poder). "Oferecer" Sabino a Sejano que planeava eliminar alguns dos amigos próximos de Agripina, a fim de dar o exemplo do seu poderio - era o meio mais simples de isso acontecer:

bunc [= Sabinum] Latinius Latiaris, Porcius Cato, Petilius Rufus, M. Opsius praetura functi adgrediuntur, cupidine consulatus ad quem non nisi per Seianum aditus; neque Seiani uoluntas nisi scelere quaerebatur. compositum inter ipsos ut Latiaris, qui modico usu Sabinum contingebat, strueret dolum, ceteri testes adessent, deinde accusationem inciperent (4.68.2).

O que vai acontecer é um scelus, pois que o único caminho para atingir o consulado é por intermédio de Sejano (o que comprova a sua influência) e a vontade dele só se consegue por essa via ${ }^{116}$ : nisi... nisi associado ao nome de Sejano sublinha esta ideia, justificando-se o crime com Sejano, que náo volta a ser referido ao longo da narração deste episódio, a não ser no fim, pelas palavras de Sabino.

A figura sobre a qual recai a atenção do narrador é Lacínio Laciar (o primeiro acusador a ser nomeado). Aproveita-se uma

115 É essa a opiniāo de Corrigan 1993 334-336. Não penso, porém, que se deva entender o tom crítico do narrador como o realçar de uma problemática de índole religiosa, como a seguir discutirei.

${ }^{116} \mathrm{E}$ a Sejano chega-se por meio de intrigas: 4.74.3. 
situação anterior (modico usu Sabinum) para projectar outra no futuro (strueret dolum):

igitur Latiaris iacere fortuitos primum sermones, mox laudare constantiam quod non, ut ceteri, florentis domus amicus adflictam deseruisset; simul honora de Germanico, Agrippinam miserans, disserebat (4.68.3).

Laciar começa a sondar Sabino até conquistar a sua confiança: primum, mox, simul, postquam e iam exprimem as etapas em que as conversas têm lugar — de fortuiti sermones passa-se a laudare constantiam (perseverança mais meritória pelo contraste ut ceteri) e daqui à referência de honora relativos a Germânico e à lamentação de Agripina ${ }^{117}$.

A reacção de Sabino aos incitamentos de Laciar é justificada pela fragilidade do espírito humano, quando confrontado com desgraças: ut sunt molles in calamitate mortalium animi (4.68.3). A sententia, uma das mais comoventes dos Annales, manifesta a compaixão do narrador neste caso, "making Sabinus' behaviour seem common and intelligible to all." "118 A operação de atracção da vítima culmina num quadro patético: Sabino derrama lágrimas ${ }^{119}$ e junta as suas lamentaçóes:

etpostquam Sabinus, ut sunt molles in calamitate mortalium animi, effudit lacrimas, iunxit questus, audentius iam onerat Seianum, saeuitiam, superbiam, spes eius; ne in Tiberium quidem conuicio abstinet (4.68.3).

$\mathrm{O}$ advérbio iam reforça o valor de audentius, que assim caracteriza Laciar com uma carga ainda mais negativa. A censura a Sejano, à sua saeuitia, à superbia e às spes ${ }^{120}$, bem como as críticas

117 Agripina é vista como agente continuador do papel de Germânico: v. Walker 1952 18-19.

${ }^{118}$ Corrigan 1993 332. O tom solene e pesado é expresso pela assonância da oclusiva nasal $m$. Juntamente com a sententia em 4.69.2 - eadem ille et diutius, quanto maesta, ubi semel prorupere, difficilius reticentur —, manifestase o entendimento que o narrador tem da psicologia humana.

${ }^{119} \mathrm{O}$ verbo effundo também é utilizado, em sentido próprio, para expressar 'derramar sangue' (como em 16.35.1). Para uso metafórico, cf. Santoro L'hoir 200673.

${ }^{120}$ A aliteração em $s$ transforma os quatro elementos (Seianus, saeuitia, superbia, spes) num todo, como se a referência a um deles fosse equivalente a referir os outros. 
que não poupou a Tibério, apenas acentuam o carácter torpe e cínico da personagem ${ }^{121}$.

Como resultado, Laciar consegue o efeito de ilusão de forte amizade $^{122}$ (artae amicitiae, fidissimum):

iique sermones tamquam uetita miscuissent speciem artae amicitiae fecere. ac iam ultro Sabinus quaerere Latiarem, uentitare domum, dolores suos quasi ad fidissimum deferre (4.68.4).

"The trap was instantly sprung", num aumento de velocidade discursiva, até aqui mais lenta, pois a descrição desenrolou-se com cuidadoso pormenor. E, de facto, “Tacitus' psychological insight again animates the narrative so as to affect readers' objectivity when he adds the comment that the private conversations of Sabinus and Latiaris, because they touched on forbidden topics, created in the former's mind the false security of sincere intimacy" (Corrigan 1993331 e 332). É notável a ausência de qualquer citaçáo das palavras de Sabino, tal como acontece quando a conversa é testemunhada.

Posto isto, os delatores começam a pensar na melhor forma de denunciar o caso para conhecimento geral. $\mathrm{O}$ foco narrativo centra-se nessas figuras, que o narrador se escusa de nomear segunda vez:

Consultant quos memoraui quonam modo ea plurium auditu acciperentur. nam loco in quem coibatur seruanda solitudinis facies; et si pone foris adsisterent, metus uisus, sonitus aut forte ortae suspicionis erat. tectum inter et laquearia tres senatores haud minus turpi latebra quam detestanda fraude sese abstrudunt, foraminibus et rimis aurem admouent (4.69.1). ${ }^{123}$

${ }^{121}$ Este ponto de vista não é consensual. Furneaux 1896570 afirma que, na frase audentius iam onerat Seianum..., " [t] he return to the historical present marks the change of subject again to Latiaris.” Martin — Woodman 1989250 secundam essa interpretação, mas Corrigan 1993332 interpreta onerat como "Sabinus' exasperation with Sejanus' stewardship over Roman politics."

${ }^{122}$ Com a construção tamquam e conjuntivo e com os vocábulos speciem, quasi: cf. Aubrion 1985 179. A aparência da amizade inscreve-se na temática da dissimulação e ocultação-revelação, representada significativamente na dicotomia público-privado de 4.68 .1 (sectator domi, comes in publico) e no esconderijo (abstrudunt, 4.69.1) dos senadores que testemunham a conversa que compromete Sabino.

${ }^{123}$ Recupera-se a avaliação dos acontecimentos como dolus ou fraus. 
Retoma-se, para exprimir esta ideia, o uso de um verbo como consulto, confirmando o carácter reflectido do dolus ${ }^{124}$. Nessa medida, são consideradas todas as condicionantes que poderiam levar ao fracasso e a decisão acaba por tornar o projecto ainda mais turpis.

Montado o cenário, falta atrair a vítima, o que representa um redireccionar da perspectiva narrativa para Sabino:

interea Latiaris repertum in publico Sabinum, uelut recens cognita narraturus, domum et in cubiculum trahit praeteritaque et instantia, quorum adfatim copia, ac nouos terrores cumulat (4.69.2).

O percurso publico - domum - cubiculum cria a ideia de solidão e secretismo em que a conversa ocorreria, que o leitor sabe já ser ilusória ${ }^{125}$, assistindo conscientemente à caminhada que Sabino faz para o dolus - e para a sua perdição.

O narrador, como antes, não reproduz o discurso incriminatório de Sabino. Faz sempre depender de Laciar as suas palavras, confirmando, senão a inocência, pelo menos a vitimização de Sabino: ille et diutius, quanto maesta, ubi semel prorupere, difficilius reticentur (4.69.2). ${ }^{126}$ Deve, pois, notar-se que as únicas palavras que neste episódio são proferidas por Sabino são a acusação que lança a Sejano, quando, amarrado, está a ser arrastado pelas ruas.

Passa-se à acusação, que é apressada ${ }^{127}$, tal como a velocidade discursiva, pois a narrativa surge despojada de pormenores e repleta de acção: properata inde accusatio missisque ad Caesarem litteris ordinem fraudis suumque ipsi dedecus narrauere (4.69.3). De novo, é lembrado o carácter pernicioso do esquema montado para apanhar Sabino, de que a repetição do termo fraus é prova (ao lado dos anteriores scelus e dolus $\left.{ }^{128}\right)$. Tibério toma conhecimento disto e a sua reacção surge em carta:

${ }^{124}$ Cf. compono, 4.68.2

${ }^{125}$ Ilusório é também o motivo por que Sabino é chamado ao quarto, pois as informaçóes que lhe são transmitidas pouco têm de novidade (uelut recens cognita; praeteritaque et instantia).

${ }^{126} \mathrm{~V}$. supra, a propósito da sententia anterior sunt molles in calamitate mortalium animi (4.68.3).

127 Quando Tibério autorizou a prisão de Sabino, também não houve demora na prossecução da vingança: nec mora quin decerneretur (4.70.1).

${ }^{128} \mathrm{Em}$ 4.71.1 diz-se que os acusadores são flagitii repertores. 
Sed Caesar sollemnia incipientis anni kalendis Ianuariis epistula precatus uertit in Sabinum, corruptos quosdam libertorum et petitum se arguens, ultionemque haud obscure poscebat (4.70.1).

O motivo para que Tício Sabino tenha sido trazido para a prisão ${ }^{129}$ tem que ver com a amizade por Germânico, mas, nesta carta, Tibério refere a corrupçáo de libertos (corruptos quosdam libertorum) e um atentado contra si próprio (petitum se arguens). De facto, haviam sido feitas críticas a Tibério (ne in Tiberium quidem conuicio abstinet, 4.68.3), mas por Laciar, tendo Sabino apenas confidenciado questus e dolores (4.68.3 e 4.68.4). Já depois da condenação, o princeps agradece ao senado o facto de um homem hostil ao estado (infensum rei publicae, 4.70.4) ter sido punido. Nesta afirmação, o bem-estar do imperador confunde-se com o bem da res publica, de que Tibério é metonímia. Esta premissa pretende tornar legítimo o pedido dissimulado que faz: adiecto trepidam sibi uitam, suspectas inimicorum insidias, nullo nominatim compellato; neque tamen dubitabatur in Neronem et Agrippinam intendi (4.70.4). Torna-se evidente que o ataque a Sabino visa antes atingir a família de Germânico ${ }^{130}$.

Às ordens de Tibério, Tício Sabino é detido, arrastado pelas ruas, assoladas pelo medo:

et trahebatur damnatus, quantum obducta ueste et adstrictisfaucibus niti poterat, clamitans sic inchoari annum, has Seiano uictimas cadere. quo intendisset oculos, quo uerba acciderent, fuga uastitas, deseri itinera fora. et quidam regrediebantur ostentabantque se rursum id ipsum pauentes quod timuissent (4.70.1-2).

Esta descrição afigura-se manifestamente dramática e pictórica. A acção está in fieri, como mostram os termos que expressam simultaneidade e repetição de movimentos (clamitans, quo... quo, o assíndeto), e os que expressam vazio e extensão espacial (fuga, uastitas, deseri, itinera, fora). A reacção dos populares retoma a isotopia do medo, a que já se havia feito alusão antes (4.69.3):

${ }^{129}$ É curioso que não se descreva a sua morte, a que se faz apenas alusão: perniciosa (4.18.1), foedum (4.68.1), uictimas (4.70.1).

130 Walker 1952, ainda que afirme que "[n]o grounds are specified for the attack on Sabinus" (104), relaciona a acusação com uma conspiração "in favour of Nero" (263). Considero, todavia, o episódio de Tício Sabino como uma etapa da escalada de Sejano em direcção ao poder (para o que precisava de eliminar a descendência de Germânico e seus apoiantes). 
non alias magis anxia et pauens ciuitas, tegens aduersum proximos; congressus, conloquia, notae ignotaeque aures uitari; etiam muta atque inanima, tectum et parietes circumspectabantur $(4.69 .3)^{131}$.

Mesmo que hiperbólica, a interpretação feita pelo narrador é significativa precisamente por causa desse aproveitamento. A imagem pintada de uma cidade cheia de medo decorre do efeito de emoção generalizada, pelo uso dos verbos e substantivos abstractos, "it seems not only that men are afraid, but that the whole scene is a manifestation of fear. This power of diffusing an emotion without diminishing its intensity is a rare gift which Tacitus possesses" (Walker 1952 191). O relato do temor generalizado inscreve o episódio num cenário ainda mais trágico — o phobos que a tragédia provoca no público é aqui reflectido na população que até demonstra medo por ter sentido medo (pauentes quod timuissent).

Sabino gritou como pôde, demonstrando não ter perdido a coragem (constantia) que no início lhe havia sido atribuída. $\mathrm{O}$ nome de Sejano é novamente referido, como que a confirmar ser ele o responsável pelo acto infame ali praticado: "he has been ominously conspicuous by his absence”. No capítulo 70, Tibério substitui o papel dos acusadores. Corrigan sugere que a crítica do narrador tem que ver, antes de mais, com questóes religiosas e não porque a acusação de Sabino seja excepcional em termos jurídicos (Corrigan 1993 334). No entanto, no âmbito geral da obra, é preciso inscrever o caso como exemplar da perseguição daqueles que pertenciam ao partido de Agripina (4.17.3), até porque por duas vezes foi afirmado que o que perdia Sabino era a amizade de Germânico. A fechar a narrativa deste episódio, o narrador inibe-se de revelar o destino dos acusadores, mas desvenda que o fim que os espera é a perdição:

Ni mihi destinatum foret suum quaeque in annum referre, auebat animus antire statimque memorare exitus quos Latinus atque Opsius ceterique flagitii eius repertores habuere (4.71.1).

${ }^{131}$ Neste passo, que mostra um sentimento de desconfiança geral, quer de amigos, quer de desconhecidos, assim como de muta atque inanima, ecoa em polaridade inversa a cena de armadilha em que Sabino foi apanhado (tectum inter et laquearia; foraminibus et rimis aurem admouent). 
A narrativa é deste modo projectada para o futuro, alargando a complexidade do tecido narrativo ${ }^{132}$.

Encontra-se neste episódio um claro exemplo de subversão de valores morais, que tanto preocupa o narrador e que conduz à desonra cada vez mais vergonhosa: a fides que Sabino depositou em Laciar foi traída de forma premeditada e calculista. Numa perspectiva trágica, o erro de ter considerado Laciar seu amigo configura assim a sua hamartia. Pelo excesso de confiança, Sabino é levado à hybris (iique sermones tamquam uetita miscuissent, 4.68.4; eadem ille et diutius, 4.69.2), castigada pelo próprio Tibério (katastrophê).

\subsection{A CASA DE GERMÂNico}

Para alcançar os seus objectivos de eliminação da casa de Germânico, Sejano rodeia-se dos acusadores mais experientes ${ }^{133}$, corrompe $^{134}$ e persegue os amigos de Agripina ${ }^{135}$. Ele defende com insistência (como revelam os imperfeitos do indicativo instabat ... incusabatque) que só a eliminação de um ou outro membro do partido de Agripina poderia travar a ameaça de guerra civil:

instabat quippe Seianus incusabatque diductam ciuitatem ut ciuili bello: esse qui se partium Agrippinae uocent, ac ni resistatur, fore pluris; neque aliud gliscentis discordiae remedium quam si unus alterue maxime prompti subuerterentur (4.17.3).

Posto isto, o prefeito do pretório parece justificar a sua actuação insidiosa: pensa, então, em começar por eliminar o filho mais velho

132 Aubrion 1985 126. O destino de Lacínio Laciar é narrado em 6.4.1, onde se diz: praecipuus olim circumueniendi luendae poenae primus fuit.

133 Aliás, escolhe-os cuidadosamente (delegerat), sendo classificados de callidi (em 4.12.4); cf. 4.49.3.

${ }^{134}$ Desses cúmplices, são nomeados Júlio Póstumo (4.12.4), caracterizado como peridoneus (per-intensifica a noção de idoneus, conferindo-lhe o sentido de completude: v. OLD s.v. per- e Ernout - Meillet 1959 s.v. per), em relação aos consilia de Sejano. Este encontra-se inter intimos de Augusta pelo adultério de Mutília Prisca porque esta tornava (efficiebat) Augusta insociabilis com a nora. A afirmação de Augusta enquanto suapte natura potentiae anxiam (4.12.4) inscreve a personagem na sede de poder a que está ligada desde o início dos Annales.

135 É neste contexto de perseguição dos partidários de Agripina e dos filhos de Germânico que personagens como Gaio Sílio, Sósia Gala (4.18.1-20.4) e Tício Sabino são envolvidos em processos de maiestas. 
de Germânico, Nero, por este se encontrar indubitavelmente na linha de sucessão:

adsimulabatque iudicis partis aduersum Germanici stirpem, subditis qui accusatorum nomina sustinerent maximeque insectarentur Neronem proximum successioni et, quamquam modesta iuuenta, plerumque tamen quid in praesentiarum conduceret oblitum, dum a libertis et clientibus, apiscendae potentiae properis, extimulator ut erectum et fidentem animi ostenderet: uelle id populum Romanum, cupere exercitus, neque ausurum contra Seianum qui nunc patientiam senis et segnitiam iuuenis iuxta insultet (4.59.3).

O ambiente de perseguição é evidente e assustador: Nero é vigiado de dia e de noite ${ }^{136}$ e encontra-se rodeado dos cúmplices de Sejano, que lhe inflamam ideais de governação; Nero acredita nestes comentários encomendados. Apanhado nas malhas do conjunto de intriguistas, o filho de Germânico começa a alimentar o desejo de poder ${ }^{137}$ :

Haec atque talia audienti nihil quidem pranae cogitationis, sed interdum uoces procedebant contumaces et inconsultae, quas adpositi custodes ${ }^{138}$ exceptas auctasque cum deferrent neque Neroni defendere daretur, diuersae insuper sollicitudinum formae oriebantur. (...) enimuero Tiberius toruus aut falsum renidens uultu: seu loqueretur seu taceret iunenis, crimen ex silentio, ex uoce (4.60.1-2).

Também com o objectivo de eliminar Nero, Sejano aproveita o carácter de Druso (filho de Germânico), influenciando-o com promessas de poder. De novo, é a inexperiência e o carácter ingénuo de uma personagem que a faz acreditar nas promessas vâs de Sejano:

qui fratrem quoque Neronis Drusum traxit in partis, spe obiecta principis loci si priorem aetate et iam labefactum demouisset. atrox Drusi ingenium super cupidinem potentiae et solita fratribus odia accendebatur inuidia quod mater Agrippina promptior Neroni erat.

${ }^{136}$ Lívia Júlia desempenha um papel fundamental nessa vigilância, por intermédio da sua filha, casada com Nero: ne nox quidem secura, cum uxor uigilias somnos suspiria matri Liuiae atque illa Seiano patefaceret (4.60.2).

137 De notar que dele se diz ter modesta iunenta. O leitor recorda as características da personalidade e a inexperiência de um jovem, lembrando Libão Druso, que, fiado nas palavras de um amigo, foi levado à perdição. Ao dar ouvidos a estes conselhos, Nero segue para um fim trágico.

${ }^{138}$ Libão Druso, Pisão, Agripa Póstumo são outras personagens que viveram ou estiveram sob custódia no último momento da vida. 
neque tamen Seianus ita Drusum fouebat ut non in eum quoque semina futuri exitii meditaretur, gnarus praeferocem et insidiis magis opportunum (4.60.2-3).

Neste passo, reconhecem-se as várias isotopias que configuram a actuação (insidiis, traxit in partis ${ }^{139}$ ) e o comportamento (meditaretur, gnarus) de Sejano: o uso da spes obiecta (que se tornará uana ${ }^{140}$ : quoque semina futuri exitii $\left.{ }^{141}\right)$, o aproveitamento do carácter da vítima (atrox ingenium, solita fratribus odia) e das circunstâncias (inuidia quod mater Agrippina promptior Neroni erat; cf. 2.42.1).

Com a perda de grande parte do livro $\mathrm{V}$, não nos chegou a narrativa da morte de Nero nem a que contava os motivos do exílio de Agripina. O fim de Druso é contado em 6.23.2:

Drusus deinde extinguitur, cum se miserandis alimentis, mandendo e cubili tomento, nonum ad diem detinuisset. tradidere quidam praescriptum fuisse Macroni, si arma ab Seiano temptarentur, extractum custodiae iunenem (nam in Palatio attinebatur) ducem populo imponere. mox, quia rumor ${ }^{142}$ incedebat fore ut nuru ac nepoti conciliaretur Caesar, saeuitiam quam paenitentiam maluit.

Afinal, o poder esteve-lhe destinado, mas as esperanças que colocou em vir a governar revelaram-se vás.

${ }^{139}$ Cf. sumitur in conscientiam (4.3.4).

${ }^{140}$ Tal como no caso de Pisão (Cap. 2, sec. 4).

141 Também em relação a Agripina se preparou um futurum exitium (4.52.1).

${ }^{142}$ Esta história lembra a reconciliação de Augusto com Agripa Póstumo, admitida igualmente como um rumor (1.5.1-2; cf. Cap. 2, sec. 1); a história de Druso aproxima-se da de Agripa Póstumo também pelo facto de aparecerem sósias que activam a isotopia realidade-aparência (2.39.1-40.3 e 5.10.1-2). 


\section{Liberdade de expressáo: Cremúcio Cordo}

É importante salientar o processo de incriminação do historiador Cremúcio Cordo como um exemplo de exortação à liberdade de expressão e ao livre acesso às obras de História, elemento fulcral para a preservação da memória colectiva ${ }^{143}$. D. Sailor 2008251 considera este caso "a crucial event in the legitimation of Tacitus' historiography, and his trial, speech, and death work to lend Tacitus the prestige earned by Cremutius' experience without Tacitus having to replicate that experience in his own biography." $\mathrm{O}$ episódio tem mais importância por vir ilustrar as palavras do narrador nos capítulos anteriores ${ }^{144}$. É. Aubrion confirma que "[e]n plaçant le discours de Crémutius Cordus à la suite d'une digression sur la matière des Annales et sur les risques courus par l'historien, en le commentant de façon tout à fait personnelle et bienveillante (Ann. 4.35.6-7), Tacite ne laisse pas douter qu'il approuve son héros." ${ }^{45}$ Também relevante é o facto de "[ $t$ ]he rhetorical strategies that defend an author can also function to demonstrate that he needs defense, and so create the strong impression that his book matters", como afirma ainda D. Sailor 2008251.

Apesar da importância que o caso adquire em termos estruturais (narrado logo no início de 25, o leitor acaba por retê-lo como o mais importante desse ano), ele é apresentado de forma simples, faltando-lhe pormenores consistentes para a sustentaçãa de uma acusação de maiestas ${ }^{146}$ :

${ }_{143}$ Sobre o modo como a personagem se dirige ao futuro, escreveu O'Gorman 2000 97. A mesma autora observa ainda (98) a ligaçấo entre a narrativa histórica e as formas de governo: "he [= Tacitus] goes on to specify the type of knowledge necessary under each regime, knowledge which the historical narrative is presumed to supply."

${ }_{144}$ Por mim estudados no Cap. 1, sec. 4. Quanto à relação que estes capítulos têm com os seguintes, Devillers 199452 identifica três níveis: "le procès de majesté", "la puissance de Séjan" e "l'activité du sénat"; cf. Sinclair 19912817 e Sailor 2008 250-313.

145 Aubrion 1985 610; cf. Devillers 1994 233-234.

146 Esta assunçẫo decorre, fundamentalmente, da possibilidade de se confrontar o texto de Tácito com as versôes de Suetónio, Díon Cássio e Séneca (Consolatio ad Marciam, sendo Márcia a filha de Cremúcio Cordo). Por outro lado, a obra de Cremúcio data do principado de Augusto, pelo que se verifica um atraso significativo na sua censura. A análise que agora se apresenta não 
Cornelio Cosso Asinio Agrippa consulibus Cremutius Cordus postulatur nouo ac tunc primum audito crimine, quod editis annalibus laudatoque M. Bruto C. Cassium Romanorum ultimum dixisset. accusabant Satrius Secundus et Pinarius Natta, Seiani clientes (4.34.1).

O enredo constrói-se com a referência a uma acusação desconhecida até então: o louvor de duas personalidades ligadas à República e ao combate contra a ditadura, precursora do principado. É notável a expressão em ablativo absoluto ligada a Bruto e em oração subordinada circunstancial causal referente a Cássio: a acusaçáo sustenta-se no facto de Cremúcio ter considerado Cássio o último dos Romanos, apesar de ter também louvado Bruto ${ }^{147}$.

Os intervenientes no processo são apresentados: o acusado (Cremúcio Cordo ${ }^{148}$ ), os acusadores (Sátrio Secundo e Pinário Nata), e o mentor do processo (Sejano, cuja ausência do desenrolar do caso se revela "conspicuous"149). O aposto Seiani clientes atribui profundidade histórica a Sátrio Secundo e a Pinário Nata, por se subentender uma relação anterior entre estas personagens ${ }^{150}$. É o facto de os acusadores serem clientes de Sejano que deixa adivinhar o desfecho da história e quem está realmente por trás da maquinação ${ }^{151}$ : id perniciabile reo et Caesar truci uultu defensionem accipiens, quam Cremutius relinquendae

tem a intenção de contrastar versóes nem completar o texto dos Annales com dados que podem ser recolhidos nestes testemunhos. Tal estudo tem já vasta bibliografia: Furneaux 1896 529-532.

${ }_{147}$ Sailor 2008295 n.96 justifica assim o uso do ablativo absoluto.

${ }^{148}$ Em rigor, em julgamento também estava a memória dos libertadores Bruto e Cássio, como no episódio dos funerais de Júnia (3.76.2), onde as suas imagens são notadas pela ausência (cf. ainda 16.7.2). Sobre as imagens que aparecem ou não, v. O’Gorman 200060 n.25 e Martin 1990 1544. Devillers 1994161 nota na referência a Bruto e Cássio um elemento estruturante da unidade da obra.

${ }^{149}$ Martin — Woodman 1989 178. Os mesmos comentadores inscrevem o processo no rol de maquinações de Sejano (como Devillers 199452 e 233). Durante a acusação de Tício Sabino, Sejano mantém-se igualmente ausente: mas é por causa dele que as acçóes acontecem.

150 Aliás, no livro VI volta a afirmar-se essa relação. Sátrio Secundo era uma personagem influente (6.8.5), mas acabou por se tornar um dos mais importantes traidores de Sejano (6.47.2).

${ }^{151}$ Martin — Woodman 1989 178: "both elements [accusabant e Seiani clientes] are emphasised by their position in the sentence". 
uitae certus in hunc modum exorsus est (4.34.2). ${ }^{152}$ Tibério assume a expressão fria e fechada com que costuma assistir aos julgamentos, aproximada de, pelo menos, dois outros casos por ele conduzidos: Libão Druso (non uultu alienatus, 2.28.2) e Pisão (Tiberium sine miseratione, sine ira, obstinatum clausumque, 3.15.2) ${ }^{153}$. Sendo possível entender essa expressão glacial como insensibilidade, é com a personalidade fria, distante e fechada que o leitor associa semelhante comportamento ${ }^{154}$.

O desenvolvimento do discurso de defesa de Cremúcio Cordo é anormal, não só pela sua extensão ${ }^{155}$ e pela forma em oratio recta ${ }^{156}$, como pelo facto de ser a demonstração de um acto de coragem de alguém que sabe qual vai ser a sentença, pois não tem qualquer indício de clemência de parte do príncipe ${ }^{157}$ :

uerba mea, patres conscripti, arguuntur: adeo factorum innocens sum. sed neque haec in principem aut principis parentem, quos lex maiestatis amplectitur (4.34.2).

Cordo realça o conflito entre a prática e a palavra (escrita). Esta oposição testemunha e confirma que a acusação é simplesmente ter louvado os assassinos de Júlio César - Brutum et Cassium

152 A fórmula id perniciabile reo retoma o tema pernicies innocentium, confirmado pelo facto de Cremúcio Cordo se declarar inocente. Sobre accipiens, v. Furneaux 1896530.

${ }^{153}$ Há, ainda assim, uma diferença na retórica do discurso: essa atitude é destrutiva para Cremúcio Cordo, mas nos outros dois casos ela inflige terror nos acusados, retirando-lhes todas as esperanças.

${ }^{154}$ De facto, Walker 1952103 realça que a expressão que Tibério assume e o facto de os acusadores serem clientes de Sejano "are sufficient to imply that Tiberius desired the condemnation."

155 Em contraste, os acusadores não são citados, o que significa que o narrador privilegia as vítimas (e esta em particular) em detrimento dos carrascos da tirania (Aubrion 1985 608).

156 Aliás, no dizer de Aubrion 1985 608, “[1]'emploi du style direct (...) implique à la fois que le narrateur soit moins 'interventionniste' et qu'il entre en sympathie avec les héros historiques comme tout auteur dramatique sait le faire avec les personnages auxquels il donne la vie."

${ }^{157}$ Por seu lado, Sailor 2008308 comenta assim este discurso: "it is actually quite banal, and does not breathe candor but 'figured speech.' Once death is certain, there is no reason not to burn the whole house down, rhetorically speaking". Também Cramer 1945193 diz que "the trial was a farce, and Cordus knew it." Outra perspectiva tem Aubrion 1985 611: "Convaincu de la justesse de sa cause, confiant dans le jugement de la postérité, cet intellectuel passionné néglige de faire une captatio beneuolentiae". 
laudanisse dicor (4.34.2) espelha perfeitamente a acusação de que o narrador deu conta antes, laudatoque M. Bruto C. Cassium Romanorum ultimum dixisset (4.34.1) - , e não o facto de ter criticado alguém, como foi por exemplo o caso de Cássio Severo ${ }^{158}$ : é essa a novidade na acusação que o narrador designava com a expressão nouo ac tunc primum audito crimine ${ }^{159}$.

A assunção da culpa de Cremúcio Cordo ter louvado os tiranicidas revela-se uma importante observaçáo teórica sobre o alargamento do âmbito da lei de traição, porque esta só compreendia ataques ao príncipe ou ao pai deste ${ }^{160}$. Contudo, louvar os assassinos do avô do actual imperador é, em rigor, incompatível com o conteúdo do discurso de Cremúcio Cordo, que tem consciência de que a lei se aplica a palavras. De facto, se se pode dizer que a lei conhece um aumento do seu escopo (por incluir mais laços da família imperial), também é verdade que Cordo muda a interpretação da sua acusação para outro tema: quorum [= Bruti et Cassii] res gestas cum plurimi componerint, nemo sine honore memorauit (4.34.2). O que está em causa passa a ser a inserção de Cremúcio Cordo numa tradição que nunca deixou de recordar Bruto e Cássio ${ }^{161}$ com honra porque tem liberdade para isso. Por isso, o discurso acaba por se tornar "a history of the place of history in politics” (O’Gorman 2000 100).

Ao citar autoridades, Cordo mistura autores que louvaram figuras tradicionalmente ligadas à República com outros autores que criticaram e injuriaram os que começavam a estabelecer a nova ordem política. Aubrion adverte que estes exemplos "illustrent cette affirmation, contenue dans le premier chapitre des Annales, que l'historiographie était encore indépendante sous le principat

${ }^{158}$ V. 1.72.3 e 4.21.3. Cf. Martin — Woodman 1989179 e Cramer 1945 $175-178$.

159 "Never before had charges of literary treason been based on any evidence as flimsy as this", defende Cramer 1945 193. A constante referência à novidade das acusaçóes contribui para a caracterização do principado de Tibério como um tempo de terror; cf. Libão Druso: tum primum reperta sunt (2.27.1) e callidus et noui iuris repertor Tiberius (2.30.3).

${ }^{160}$ Existe a possibilidade de parens ter como referente Lívia: Furneaux 1896 530 e Shotter 1989 164. Apuleia Varila havia sido acusada de maiestas em 17, sob o pretexto de ter desrespeitado Augusto, Tibério e Lívia Augusta, tornando assim possível esta leitura (2.50.1-2).

${ }^{161}$ Trata-se de uma subversão do sentido da acusação que é feita a Cremúcio Cordo. O narrador, ao solidarizar-se com o réu, como se perceberá pela conclusão, legitima essa subversão. Cf. ainda Daitz 1960 44-45. 
d'Auguste"162. Assim, Tito Lívio louvou Pompeio (a ponto de Augusto o apelidar de "pompeiano" ${ }^{163}$ ); Cecílio Cipião, Afrânio ${ }^{164}$ e Asínio Polião ${ }^{165}$ louvaram Cássio e Bruto; Messala Corvino ${ }^{166}$ louvou Cássio; e Cícero louvou Catão. Por outro lado, António e Bruto criticaram Augusto, enquanto Bibáculo e Catulo ${ }^{167}$ criticaram Júlio César ${ }^{168}$ e Augusto. No dizer de R. Syme, neste discurso, Cremúcio "cites examples of candour, licence, or governmental toleration from the recent past - which enables Tacitus to pay a handsome compliment to Livy, to allude to the histories of Asinius Pollio and the memoirs of Messalla Corvinus; and certain poets can be noticed who impinged upon political struggles in the closing epoch of the Free State" (Syme 1958 337-338). D. Sailor, porém, analisa estas palavras em função do contexto em que se inscrevem, e a conclusão náo pode ser positiva: "Although he spends about half of his speech (...) listing examples of the tolerance Julius Caesar and (especially) Augustus exercised when faced with critical writings, he nonetheless obligingly refrains from the obvious step of referring to Augustus', to say nothing of Tiberius', toleration of his own book, even though that information would have been immensely useful for pleading innocence as well as for condemning the process" (Sailor 2008 296).

Ao utilizar estes exemplos, Cremúcio pretende também diluir a diferença entre o louvor que fez com críticas que outros fizeram, tendo como objectivo defender a memória colectiva (tema central deste episódio). Há, todavia, exemplos que são claramente falaciosos porque não comparáveis com o presente

162 Aubrion 1985 611. Sobre esta concordância, cf. O’Gorman 200099.

163 Martin - Woodman 1989 179-180 observam que existe pouca probabilidade que Lívio fosse sectário de Pompeio. Sailor 2008 253-254 refere que "Augustus' supposed teasing of Livy for his Pompeian leanings (...) might be seen not as a serious objection, but as a favor on the princeps' part to a work only too neatly in the line with the new era".

164 Figuras ligadas à república que morreram na sequência da batalha de Tapso (46 a.C.).

${ }^{165}$ Pai de Asínio Galo, de que herdou a ferocia (1.12.6).

166 Pai de Valério Messalino (1.8.4) e de Cota Messalino (4.20.4, 5.3.2, 6.5.1-7.1); este último esteve ainda envolvido no julgamento de Libão Druso (2.32.1) e foi cônsul em 20 (3.2.2).

167 Sabe-se que Catulo pediu desculpa pela ofensa (Suet. Iul. 73); Cf. Shotter 1989165.

${ }^{168} \mathrm{O}$ uso de dictator sublinha o poder de Júlio César: Furneaux 1896531 e Shotter 1989165. 
cenário, como é o caso da praeteritio em que Cremúcio Cordo diz non attingo Graecos (4.35.1), uma vez que os pleitos e discussóes dos gregos se fazem por palavras, e não têm consequências práticas (o que configura uma desresponsabilização da palavra e a sua menorização). Já quando a mesma personagem afirma sed maxime solutum et sine obtrectatore fuit prodere de iis quos mors odio aut gratiae exemisset (4.35.1), está a falar de si próprio em termos genéricos e sentenciosos ${ }^{169}$ e introduz o único argumento que poderá jogar a seu favor: o apelo à liberdade de expressáo, com o reconhecimento de que a sua obra não é um incitamento à guerra civil:

num enim armatis Cassio et Bruto ac Philippensis campos optinentibus belli ciuilis causa populum per contiones incendo? an illi quidem septuagesimum ante annum perempti, quo modo imaginibus suis noscuntur, quas ne uictor quidem aboleuit, sic partem memoriae apud scriptores retinent? $(4.35 .2)^{170}$.

A sequência de questóes retóricas tem como efeito a criação de laços de solidariedade e cumplicidade do leitor em relação à personagem.

No fim do discurso, Cordo relança o tema da censura para a posteridade: suum cuique decus posteritas rependit; nec deerunt, si damnatio ingruit, qui non modo Cassii et Bruti set etiam mei meminerint (4.35.3). ${ }^{171}$ Com efeito, a condenação por motivos de censura acaba por se voltar contra o juiz, uma vez que o condenado também atinge a glória e, como a conclusão determinará, é um absurdo tentar apagar o passado ${ }^{172}$.

Terminado o discurso da personagem, o narrador faz uma breve alusão ao fim de Cordo pela abstinência, e da sua obra, que

${ }^{169} \mathrm{O}$ que é um argumento a favor da teoria de que a paternidade das palavras é inteiramente tacitiana: Cf. Syme 1958337 n.10 e Cramer 1945193.

${ }^{170} \mathrm{O}$ primeiro elemento disjuntivo da construção num... an tem resposta negativa e o segundo, positiva: Furneaux 1896531.

${ }^{171}$ Cf. O’Gorman 2000 102: “tyrannical suppression of literature only secures for the artist (...) is ironically undercut by his claim in the digression that glory, perpetrated in historical memory, is subject to hostile reinterpretation by future readers."

${ }^{172}$ Cf. Syme 1958 338. Também Aubrion 1985611 menciona a evocação de uma época em que as efígies de Bruto e Cássio "ont été respectées par celui qui les a vaincus ; enfin, avec l'assurance que donne la résolution d'affronter la mort, il met ses juges au défi de prononcer un châtiment qui les condamnera eux-mêmes." 
foi, porém, preservada - é a materialização de perniciabilis do início do episódio: egressus dein senatu uitam abstinentia finiuit. libros per aedilis cremandos censuere patres: set manserunt, occultati et editi (4.35.4). Tal como Libão Druso e Pisão, Cremúcio Cordo preferiu o suicídio a voltar a lutar contra a adversidade dos seus acusadores e de um princeps que não dava sinais de compaixão por ninguém.

A conclusão configura a identificação do narrador com a personagem. Trata-se de uma declaração sentenciosa sobre o carácter ridículo da censura da História e da tentativa de apagar a memória colectiva. $\mathrm{O}$ narrador, que já antes tinha indiciado estar do lado do réu, mostra-se jocoso e confirma mesmo algumas ideias expostas no discurso de Cremúcio Cordo ${ }^{173}$ :

quo magis socordiam eorum inridere libet qui praesenti potentia credunt extingui posse etiam sequentis aeui memoriam. nam contra punitis ingeniis gliscit auctoritas, neque aliud externi reges aut qui eadem saeuitia usi sunt nisi dedecus sibi atque illis gloriam peperere (4.35.4).

D. Sailor (com base em Moles 1998) estabelece uma interessante relação entre este episódio e o discurso proferido por Tibério também nesse ano (4.37.2-38.3), o qual tem que ver igualmente com preservação da memória para o futuro: "Tiberius' speech (...) exists in order to attribute to him an ambition Tacitus can in turn destroy, so that he can position himself as the successful avenger of Cremutius." E de facto, "Annals is here condign punishment: it harms Tiberius by establishing forever his disgrace", destino merecido também por ter perseguido Cremúcio Cordo. "Tacitus pays him back in the same coin. Just as Tiberius' hostile expression as he listened to Cremutius' defense-speech (Caesar truci vultu defensionem accipiens, 4.34.2) meant he had already made up his mind, and Cremutius' words would avail him nothing, so now Tacitus gives Tiberius' defense-speech (defensionem, 4.37.2) a hearing, but he already knows what his verdict will be" (Sailor $2008304)$.

${ }^{173}$ E.g., nam contra punitis ingeniis gliscit auctoritas vs qui non modo (...) set etiam mei meminerint. Cf. 14.50 .2 e Ag. 2.1 e 2.3. 


\section{Conclusão}

Poucos foram os países europeus que, em algum momento da sua história recente, não viveram em regimes ditatoriais ou de repressão, que estão, aliás, em vigor em muitos países africanos, asiáticos e sul-americanos. Esta imagem política é em tudo semelhante àquela descrita por Tácito, referindo-se à corte de Tibério. Mesmo nas democracias, há características da política romana que se encontram activas. Ao invés, os exemplos de coragem, justiça, constantia e liberdade que Tácito retrata continuam a afirmar-se como modelos para o cidadáo do século XXI.

A universalidade da obra de Tácito é, assim, inequívoca no que concerne ao âmbito das civilizações e dos caracteres humanos. Plínio-o-Moço tinha razáo quando previa para as histórias do seu amigo a imortalidade (Ep. 9.14), pois a identificaçáo da psicologia das personagens tacitianas com outras, modernas e contemporâneas, apenas confirma que valerá sempre a pena reler o historiador que, no início do século II da nossa era, escrevia: memoriam quoque ipsam cum uoce perdidissemus, si tam in nostra potestate esset obliuisci quam tacere (Ag. 2.4).

São vários os pontos de vista com que se pode apreciar a obra de Tácito. No âmbito de uma dissertação de mestrado em Estudos Clássicos, com especialização em Literatura Latina, restringi-me à análise literária do discurso. Estudei, no campo retórico, aquilo que na História, na Psicologia, na Antropologia continua a ser matéria de indiscutível interesse.

$\mathrm{Na}$ Antiguidade, a História era um género literário que servia princípios estéticos e retóricos próprios. Neste âmbito, a conspiração ou intriga de bastidores é um campo primordial para o escritor exercer a sua arte narrativa, indo assim ao encontro do gosto dos seus leitores. O mistério e a incerteza que a intriga evoca responde, no geral, à busca de evasáo que o leitor da Antiguidade procurava na historiografia - não diferente daquela que nós procuramos hoje num romance.

Nesta perspectiva, um escritor como Tácito labora num espaço limitado de informação - nas suas palavras: nobis in arto et 
inglorius labor. Os assuntos que trata situam-se entre a revelaçãoocultação e silêncio-palavra, e sendo sempre os mesmos, o autor preocupa-se em náo entediar o leitor: nos saeua iussa, continuas accusationes, fallaces amicitias, perniciem innocentium et easdem exitii causas coniungimus, obuia rerum similitudine et satietate.

Foi objectivo desta dissertação estudar de que modo o discurso de Tácito transmite e dota uma mensagem de significado em ambientes misteriosos de intriga. Desta maneira, foi possível apreciar, no campo da estética literária, as páginas dos Annales com um interesse constante, que a uariatio renova.

Tem vindo a ser realçado que a construção de um discurso que transmite uma informação está ligada à manipulação da atenção do leitor. A informação implícita joga com o grau de conhecimento deste leitor, enquanto a interpretação joga com omissões, sugestóes, innuendos, insinuaçôes e implicaçôes. De facto, porque utiliza mais implicaçóes do que explicitaçóes, Tácito enfatiza certos caracteres e incidentes, de modo a moldar a percepção e o entendimento que o leitor terá daquela informação no decorrer da narrativa. Para isso, o autor escolhe a focalização, o modo de representação do discurso (directo, indirecto, indirecto livre), e constrói isotopias, concretizadas por meio de encadeamentos de vocábulos não escolhidos ao acaso.

Os constantes contrastes entre realidade e aparência (ou entre evidência e oculto) dão cor especial ao texto e configuram a ideia de que o fim quase nunca é feliz — aliás, em Tácito, como refiro no meu estudo, a esperança resulta sempre num vazio angustiante e é sempre a primeira a morrer. Assim, acçôes de personagens como Augusto, Lívia, Tibério, Pisão, Plancina, ou Sejano corporizam-se em ambitus, artes, dolus, fraus, insidiae, scelus, que ocorrem num ambiente obscurus ou occultus.

Por um lado, note-se também que a representação factual de acontecimentos é obscurecida pela sintaxe e pela semântica. Daí resulta uma atmosfera de incerteza e mistério que, como já disse, é típica da intriga. Por outro lado, não se pode esquecer que, na narrativa de uma conspiração, o narrador/autor defronta-se com os seus próprios limites do conhecimento. Disso nos dá conta Tácito, por exemplo, na cena da morte de Augusto: nunca se ficou a saber se quando Tibério chega a Nola o velho imperador ainda estava vivo ou não. 
Com efeito, com a narrativa do principado de Augusto, abre-se um caminho hermenêutico de grande relevo que estabelece, da parte do narrador para com o leitor, um conjunto de pistas e indícios para certa orientação na interpretação do principado de Augusto enquanto simulador de aparências, mas que se torna operativo principalmente quando aplicado ao principado de Tibério: aparência, corrupção, tentativas de obtenção de poder por meio de intrigas, entre outras isotopias. Augusto dinamiza pelos seus actos e atitudes um movimento continuado de ascensão, possível pela assunção de títulos e cargos de diversas magistraturas. Este movimento ascendente decorre da técnica de simulação e ilusão que Augusto usa para seduzir os diversos sectores da sociedade, conquistando um apoio generalizado e auferindo uma total ausência de oposição política e militar.

Significativa para entender o vazio resultante de esperanças vãs é a personagem de Germânico. É por isso que ele, a sua esposa e descendência têm tanta importância na História do principado de Tibério. Como afirmo, à volta de Germânico, cria-se uma atmosfera de esperanças (por ele ser filho de Druso e pelas suas famosas qualidades de carácter) e de empatia (pela sua condição de vítima dos odia do tio e da avó) que contribui para a sua popularidade. Esse aspecto, que é várias vezes expresso, irá resultar numa mágoa profunda aquando da sua morte, acontecimento cuja proximidade é sugerida pelo narrador, quando descreve o triunfo de Germânico no livro II. Nesse passo, Germânico entra, em comparação com o pai e com o tio Marcelo, num paradigma trágico que arrebata ao povo romano os seus amores. Este aviso de mau augúrio desvenda um fim desditoso e próximo para Germânico. De facto, a seguir ao triunfo do sobrinho e filho adoptivo, Tibério, não conseguindo o fauor do povo, pondera destruí-lo, processo que analisei com cuidado pormenor, da ida de Germânico para a Síria até ao julgamento de Pisão.

No geral, as intrigas que foram objecto de estudo nesta dissertação tiveram como agentes mulheres que ultrapassam os valores morais romanos, subvertendo-os. São os casos de Lívia Augusta e Plancina, mas recordo principalmente Lívia Júlia: esposa carissima de Druso que, perseguindo um ideal prometido por Sejano, mais não faz do que caminhar para a desonra contínua dos flagitia. 
Também os escravos actuam como agentes dessas intrigas. Sendo o seu testemunho inválido em julgamento contra o senhor, Tibério contorna essa antiga determinação com a venda ao actor publicus dos escravos, por exemplo, de Libão Druso. Os escravos representam a esfera privada dos Romanos, e por isso torturá-los para obter informaçóes secretas viola a intimidade de um cidadão. Mas nem sempre é por tortura que os escravos são cúmplices de crimes à porta fechada: Eudemo e Ligdo ajudam à morte de Druso. Ligdo era um eunuco que — dizia-se — mantinha relaçóes amorosas com Sejano... assim, o poder de sedução de Sejano é um meio de que esta personagem se servia para atingir alguns dos seus objectivos.

Também importantes agentes e maquinadores de intrigas são os acusadores dos processos de maiestas, cuja recompensa imediata é ultrajante. Exemplo deste ultraje é o episódio da perseguição de Libão Druso (no livro II). Nesse processo, manifestam-se pretensôes políticas dos acusadores, que são recompensados pela divisão da fortuna do réu e pela concessão de uma pretura aos que eram senadores.

Os acusadores de Pisão também recebem cargos políticos e magistraturas em troca da vingança da morte de Germânico. No caso de Tício Sabino, também foi a vontade de ascender politicamente que levou a que senadores o tivessem acusado. Aliás, o processo de perseguição de Tício Sabino tem interesse acrescido por confirmar a ideia de que o nível de corrupção do estado era tal, a influência de Sejano era tanta, que crimes tinham de ser perpetrados, pois só por meio de scelera se ascendia a Sejano.

Este tipo de acontecimentos é visto pelo narrador como um uetus malum, insistindo na ideia de que a delação começava a ser uma profissão e que os acusadores são um genus hominum publico exitio repertum que vêem o seu trabalho recompensado. O narrador vai, assim, denunciando uma actividade torpe que começava a ser cada vez mais praticada, a ponto de consumir o estado e ter como fim a morte de muitas pessoas. Fulcínio Trião, acusador de Libáo Druso e de um processo secundário de acusação de Pisáo, acaba por representar exemplarmente o papel de acusador profissional, cujo fim confirma a ideia de torpeza e abjecção da sua actividade.

Devo realçar que o método de análise textual seguido permitiu perceber de que modo o estilo de Tácito se arquitecta: 
o secretismo das acçóes que narra, envoltas em sombrias dúvidas, obscurece a leitura de alguns passos dos Annales. O próprio narrador o afirma. Mas o que me pareceu mais inovador foi a estratégia de expressão dessas dúvidas (são elas que acabam por justificar o relevo da dualidade realidade-aparência). Tácito expóe alguns factos ou reflecte sobre eles baseado naquilo que pensava o público contemporâneo dos acontecimentos - não se trata, muitas vezes, daquilo que ele (narrador) afirma, mas daquilo que quidam disseram, ou seja, a mudança de focalização é decisiva na interpretação do discurso. Estas versôes nem sempre são coincidentes e merecem, em alguns casos, comentário do narrador. Esta atitude revela bem a sinceridade com que a obra foi escrita. A preocupação em apresentar uma investigação histórica consistente é declarada ou sugerida em vários passos, mas a preocupaçáo com a preservação da memória colectiva, a noção de passado que não deve ser esquecido são um tema fundamental nos Annales. Por isso, apresentei, a fechar o estudo, o episódio de Cremúcio Cordo - já náo numa perspectiva inteiramente retórica, mas como um caso exemplar de como se censura e se tenta, no principado de Tibério, corromper o futuro - e a estupidez que essas acçóes representam. Este é um episódio que confirma e universaliza a importância que a História e os seus exempla podem adquirir para a preservação da memória, entendida como um património comum.

A visão particularmente negativa que Tácito tem da História romana pode ser justificada pelo contexto em que o autor se insere (que não foi alvo de estudo nesta dissertação): depois da nefanda governação de Domiciano, o historiador conhece um tempo de rara (...) felicitate ubi sentire quae uelis et quae sentias dicere licet (Hist. 1.1.4). Pode, deste modo, conjecturar-se que Tácito receia o fim dessa liberdade e que interpreta quaisquer sinais como denunciadores de um desfecho trágico. Essa tragicidade plasmase, ao longo dos Annales, por intermédio de categorizaçóes inteiramente legítimas e que, neste estudo, fui sublinhando. No entanto, ao adoptar uma posição demasiadamente céptica, o historiador tem sempre algo para ensinar, cumprindo o praecipuum munus annalium, ou seja, ne uirtutes sileantur utque prauis dictis factisque ex posteritate et infamia metus sit (3.65.1). Tácito é, para todos nós, uma lição para a vida. 


\section{Bibliografia}

\section{EDIÇÓES, COMENTÁRIOS E TRADUÇÓES}

\subsection{TácITO}

\subsubsection{Ediçóes}

C. D. Fisher, ed (1906), Cornelii Taciti Ab Excessu Diui Augusti Annalium Libri. Oxford, Clarendon Press (reimpr s.d.).

—, ed (1911), Cornelii Taciti Historiarum Libri. Oxford, Clarendon Press (reimpr s.d.).

\subsubsection{COMENTÁrios}

R. Ash, ed (2007), Tacitus. Histories, book II. Cambridge, Cambridge University Press.

C. Damon, ed (2003), Tacitus. Histories, book I. Cambridge, Cambridge University Press (reimpr 2005).

H. Furneaux, ed (1891), The Annals of Tacitus, vol. II. Oxford, Clarendon Press.

—ed (21896), The Annals of Tacitus, vol. I. Oxford, Clarendon Press.

F. R. D. Goodyear, ed (1972), The Annals of Tacitus I.1-54. Cambridge, Cambridge University Press.

—, ed (2004), The Annals of Tacitus I.55-II. Cambridge, Cambridge University Press.

R. H. Martin, ed (2001), Tacitus. Annals, books V-VI. Ed., trad. e comentários. Warminster, Aris \& Phillips.

R. H. Martin - A. J. Woodman, eds (1989), Tacitus. Annals, book IV. Cambridge, Cambridge University Press (reimpr 2001).

N. P. Miller, ed (1992), Tacitus. Annals book I. Londres, Bristol Classical Press (reimpr 2001). 
D. C. A. Shotter, ed (1989), Tacitus. Annals, books IV. Ed., trad. e comentários. Warminster, Aris \& Phillips.

A. J. Woodman - R. H. Martin, eds (1996), The Annals of Tacitus book III. Cambridge, Cambridge University Press (reimpr 2004).

\subsubsection{TRAduçốES}

H. le Bonniec ( $\left.{ }^{2} 1989\right)$, Tacite. Histoires, vol. II. Ed. e trad. Paris, Les Belles Lettres.

— (1992), Tacite. Histoires, vol. III. Ed. e trad. Paris, Les Belles Lettres.

H. Bornecque (1999), Tacite. Annales. Trad. Paris, Garnier Flammarion.

J. L. Burnouf (1861), Oeuvres Complètes de Tacite. Trad., introd. e notas. Paris, Hachette.

J. L. F. de Carvalho (1830), Os Annaes de Cornelio Tacito traduzidos em lingoagem portugueza. Vols. I-II. Paris, J. P. Aillaud.

A. J. Church - W. J. Brodribb (2006), Tacitus. The Annals. Trad. Nova Iorque, Dover Publications.

W. H. Fyfe (1999), Tacitus. The Histories. Trad. Ed. D. S. Levene. Oxford, Oxford University Press.

H. Goelzer (1949), Tacite. Histoires, vol. II. Ed. e trad. Paris, Les Belles Lettres.

— (2002), Tacite. Histoires. Paris, Gallimard.

M. Grant (1996), Tacitus. The Annals of Imperial Rome. Trad. Londres, Penguin Books.

P. Grimal (1993), Tacite. Annales. Trad. Paris, Gallimard.

J. Jackson (1937a), Tacitus. The Annals, vol. III. Ed. e trad. Londres, William Heinemann; Cambridge (Mass.), Harvard University Press (reimpr 1963).

— (1937b), Tacitus. The Annals, vol. IV. Ed. e trad. Londres, William Heinemann; Cambridge (Mass.), Harvard University Press (reimpr 1962). 
C. H. Moore (1925), Tacitus. The Histories books I-III. Ed. e trad. Cambridge (Mass.), Harvard University Press (reimpr 1996).

A.-M. Ozanam - J. Perret (1997), Tacite. Vie d'Agricola; La Germanie. Ed. e trad. Paris, Les Belles Lettres.

K. Wellesley (1995), Tacitus. The Histories. Trad. Londres, Penguin Books.

A. J. Woodman (2004), Tacitus. The Annals. Trad. Indianápolis, Hacket Publishing.

P. Wuilleumier (1975), Tacite. Annales, vol. II. Ed. e trad. Paris, Les Belles Lettres (reimpr 1990).

(1976), Tacite. Annales, vol. III. Ed. e trad. Paris, Les Belles Lettres.

(1978a), Tacite. Annales, vol. I. Ed. e trad. Paris, Les Belles Lettres.

— (1978b), Tacite. Annales, vol. IV. Ed. e trad. Paris, Les Belles Lettres.

P. Wuilleumier - H. le Bonniec (1987), Tacite. Histoires, vol. I. Ed. e trad. Paris, Les Belles Lettres.

J. C. Yardley (2008), Tacitus. The Annals: The Reigns of Tiberius, Claudius, and Nero. Trad. Oxford, Oxford University Press.

\subsection{OUtros AUTORES (EDIÇÓES UTILIZADAS)}

H. E. Butler (1921), Quintilian. The Institutio Oratoria, vol. III. Ed. e trad. Londres, William Heinemann; Cambridge (Mass.), Harvard University Press (reimpr 1966).

H. Caplan (1954), Rhetorica ad C. Herennium de Ratione Dicendi. Ed. e trad. Londres, William Heinemann; Cambridge (Mass.), Harvard University Press (reimpr 1968).

G. de Castilho, ed (1983), Eça de Queirós. Correspondência, vol. I. Lisboa, Imprensa Nacional-Casa da Moeda.

A. C. Clark, ed (21918), M. Tulli Ciceronis Orationes, vol. II. 
Oxford, Clarendon Press (reimpr 1960).

F. Granger (1931), Vitruuius. On Architeture, vol. I. Ed. e trad. Londres, William Heinemann; Cambridge (Mass.), Harvard University Press (reimpr 1970).

J. Hardy (1932), Aristote. Poétique. Ed. e trad. Paris, Les Belles Lettres (reimpr 1985).

C. W. Keyes (1928), Cicero. De Re Publica. De Legibus. Ed. e trad. Londres, William Heinemann; Cambridge (Mass.), Harvard University Press (reimpr 1970).

A. Münthe ( $\left.{ }^{16} 2001\right)$, O Livro de San Michele. Trad. J. Cortesão. Lisboa, Livros do Brasil.

E. de Queirós (s.d. [1888]), Os Maias. Lisboa, Livros do Brasil.

H. Rackham (1942), Pliny. Natural History, vol. II. Ed. e trad. Londres, William Heinemann; Cambridge (Mass.), Harvard University Press (reimpr 1961).

B. Radice (1969), Pliny. Letters and Panegyricus, vols. I-II. Ed. e trad. Londres, William Heinemann; Cambridge (Mass.), Harvard University Press.

A. Ribeiro (2008 [1918]), A Via Sinuosa. Lisboa, Círculo de Leitores.

J. C. Rolfe (1913), Suetonius. The Lives of the Caesars, vol. I. Ed. e trad. Londres, William Heinemann; Cambridge (Mass.), Harvard University Press (reimpr 1970).

E. W. Sutton (1942), Cicero. De Oratore, vol. I. Ed. e trad. Londres, William Heinemann; Cambridge (Mass.), Harvard University Press (reimpr 1959).

W. G. Williams (1927), Cicero. The Letters to His Friends, vol. I. Ed. e trad. Londres, William Heinemann; Cambridge (Mass.), Harvard University Press (reimpr 1965).

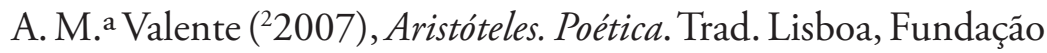
Calouste Gulbenkian. 


\section{Obras de RefERÊNCIA}

\subsection{DiCIONÁRIOS, LÉXICOS E CONCORDÂNCIAS}

D. R. Blackman - G. G. Betts (1986), Concordantia Tacitea a Concordance to Tacitus. Hildesheim, Olms-Weidmann.

P. Chantraine (1999), Dictionnaire étymologique de la langue grecque. Histoire des mots. Paris, Klincksieck.

A. Ernout - A. Meillet ( $\left.{ }^{4} 1959\right)$, Dictionnaire étymologique de la langue latine: histoire des mots. Paris, Klincksieck (reimpr 2001).

Ph. Fabia (1964), Onomasticon Taciteum. Hildesheim, Georg Olms.

F. Gaffiot (2000), Le Grand Gaffiot. Dictionnaire Latin-Français. Paris, Hachette.

A. Gerber - A. Greef - C. John (1962), Lexicon Taciteum. Hildesheim, G. Olms.

P. G. W. Glare (1982), Oxford Latin Dictionary. Oxford, Oxford University Press. (reimpr 2006).

\subsection{GramáticaS}

J. H. Allen - J. B. Greenough (1903), New Latin Grammar. Nova Iorque, Dover Publications (reimpr 2006).

A. Ernout - F. Thomas ( $\left.{ }^{2} 1953\right)$, Syntaxe Latine. Paris, Klincksieck (reimpr 2002).

B. L. Gildersleeve - G. Lodge ( $\left.{ }^{3} 1895\right)$, Gildersleeve's Latin Grammar. Wauconda: Bolchazy-Carducci Publishers (reimpr 2003).

C. Touratier (1994), Syntaxe latine. Lovaina, Peeters.

E. C. Woodcock (1959), A New Latin Syntax. Londres, Methuen (reimpr 1971). 


\subsection{Outros}

W. Dittenberger, ed (1960), Orientis Graecae Inscriptiones Selectae. Hildesheim, George Olms.

F. R. Gonçalves (1966), Vocabulário da Lingua Portuguesa. Coimbra, Coimbra Editora.

S. Hornblower - A. Spawforth, eds ( $\left.{ }^{3} 1996\right)$, The Oxford Classical Dictionary. Oxford, Oxford University Press (reimpr 2003).

M. ${ }^{a}$ H. da R. Pereira ( $\left.{ }^{4} 2000\right)$, Romana: Antologia da Cultura Latina. Coimbra, Instituto de Estudos Clássicos.

( $\left.{ }^{3} 2002\right)$, Estudos de História da Cultura Clássica, vol. II: Cultura Romana. Lisboa, Fundaçáo Calouste Gulbenkian.

\section{Teoria e História da Literatura}

M. von Albrecht (1997), A History of Roman Literature: From Livius Andronicus to Boethius. Leiden, Brill.

C. Baldick (2004), The Concise Oxford Dictionary of Literary Terms. Oxford, Oxford University Press.

R. Barthes (1966), "Introduction à l'analyse structurale des récits", Communications 8 1-27.

M. Citroni et al. (2006), Literatura de Roma Antiga. Trad. M. Miranda e I. Hipólito. Lisboa, Fundação Calouste Gulbenkian.

G. B. Conte (1999), Latin Literature: A History. Trad. J. B. Solodow, D. P. Fowler e G. W. Most. Baltimore, Johns Hopkins University Press.

J. Culler (1997), Literary theory: a Very Short Introduction. Oxford, Oxford University Press (reimpr 2000).

E. Fantham (1989a), "The Growth of Literature and Criticism at Rome" in G. A. Kennedy, ed, The Cambridge History of Literary Criticism, vol. I: Classical Criticism. Cambridge, Cambridge University Press (reimpr 1999) 220-244.

(1989b), "Latin criticism of the Early Empire" in G. A. 
Kennedy, ed, The Cambridge History of Literary Criticism, vol. I: Classical Criticism. Cambridge, Cambridge University Press (reimpr 1999) 274-296.

P. Fedeli (2002), Storia Letteraria di Roma. Nápoles, Fratelli Ferraro Editori.

A. Feldherr (2009), "Introduction" in A. Feldherr, ed, The Cambridge Companion to the Roman Historians. Cambridge, Cambridge University Press 1-8.

E. M. Forster (1927), Aspects of the Novel. Londres, Edward Arnold.

G. Genette (1972), Figures III. Paris, Éditions du Seuil.

(1983), Nouveau discours du récit. Paris, Éditions du Seuil.

S. Halliwell (1989), "Aristotle's poetics" in G. A. Kennedy, ed, The Cambridge History of Literary Criticism, vol. I: Classical Criticism. Cambridge, Cambridge University Press (reimpr 1999) 149-183.

R. Jakobson (1973), Questions de Poétique. Paris, Éditions du Seuil.

H. Lausberg (1998), Handbook of Literary Rhetoric: A Foundation for Literary Study. Trad. M. T. Bliss, A. Jansen e D. E. Orton. Leiden, Brill.

- ( $\left.{ }^{5} 2004\right)$, Elementos de Retórica Literária. Trad. R. R. Fernandes. Lisboa, Fundação Calouste Gulbenkian.

G. A. Kennedy (2003), Progymnasmata. Greek Textbooks of Prose Composition and Rhetoric. Atlanta, Society of Biblical Literature.

E. J. Kenney, ed (1996), The Cambridge History of Classical Literature, vol. II: Latin Literature. Cambridge, Cambridge University Press.

M. ${ }^{a}$ F. Marinho (2005), Um Poço sem Fundo: Novas reflexóes sobre Literatura e História. Porto, Campo das Letras.

S. Martins (2005), "Prefácio" in C. C. Branco, A Sereia. Porto, Ediçóes Caixotim 7-22.

M. ${ }^{a}$ V. L. de Matos (2001), Introdução aos Estudos Literários. 
Lisboa, Editorial Verbo.

G. Nagy (1989), "Early Greek views of poets and poetry" in G. A. Kennedy, ed, The Cambridge History of Literary Criticism, vol. I: Classical Criticism. Cambridge, Cambridge University Press (reimpr 1999) 1-77.

L. Pernot (2005), Rhetoric in Antiquity. Washington, Catholic University of America Press.

C. Reis - A. C. M. Lopes (72000), Dicionário de Narratologia. Coimbra, Livraria Almedina.

C. Reis ( $\left.{ }^{2} 1997\right)$, O Conhecimento da Literatura: Introdução aos Estudos Literários. Coimbra, Livraria Almedina (reimpr 1999).

V. M. de A. e Silva ( $\left.{ }^{8} 1987\right)$, Teoria da Literatura. Coimbra, Livraria Almedina (reimpr 2000).

_- (2001), Teoria e Metodologia Literárias. Lisboa, Universidade Aberta.

P. Waugh (2006), "Value: criticism, canons, and evaluation" in P. Waugh, ed, Literary Theory and Criticism: an Oxford Guide. Oxford, Oxford University Press 70-81.

\section{TeOria da História}

M. Bentley, ed (1997), Companion to Historiography. Londres: Routledge (reimpr 2002).

E. H. Carr (1986), Que é a História?. Trad. A. M. P. D. da Rocha. Lisboa, Gradiva.

C. Codoñer Merino (1986), Evolución del Concepto de Historiografía en Roma. Bellaterra, Servei de Publicacions de la Universitat Autònoma de Barcelona.

R. G. Collingwood (1946), The Idea of History. Oxford, Oxford University Press (reimpr 1986).

G. R. Elton (1991), Return to Essentials: Some Reflections on the Present state of Historical Study. Cambridge, Cambridge University Press. 
R. J. Evans (2000), Em Defesa da História. Trad. C. A. de S. e S. Pereira. Lisboa, Temas e Debates.

L. Gossman (1978), "History and Literature" in R. H. Canary - H. Kozicki, eds, The Writing of History: Literary Form and Historical Understanding. Wisconsin, University of Wisconsin Press 3-39.

L. O. Mink (1978), "Narrative Form as a Cognitive Instrument" in R. H. Canary - H. Kozicki, eds, The Writing of History: Literary Form and Historical Understanding. Wisconsin, University of Wisconsin Press 129-151.

A. Munslow (2000), The Routledge Companion to Historical Studies. Londres, Routledge.

E. Neff (1961), The Poetry of History. Nova Iorque, Columbia University Press.

M. Rambaud (1953), Cicerón et l'histoire romaine. Paris, Les Belles Lettres.

A. Schaff ( $\left.{ }^{2} 1988\right)$, História e Verdade. Trad. M. P. Duarte. Lisboa, Editorial Estampa.

P. Veyne (1971), Comment on écrit l'Histoire: essai d'épistémologie. Paris, Éditions du Seuil.

H. White (1976), “The Fictions of Factual Representation” in A. Fletcher, ed., The Literature of Fact. Nova Iorque, Columbia University Press.

(1978), "The Historical Text as Literary Artifact" in R. H. Canary - H. Kozicki, eds, The Writing of History: Literary Form and Historical Understanding. Wisconsin, University of Wisconsin Press 41-62.

(1985), Tropics of Discourse: Essays in Cultural Criticism. Baltimore, Johns Hopkins University Press.

— (1987), The Content of the Form: Narrative Discourse and Historical Representation. Baltimore, Johns Hopkins University Press. 


\section{Estudos sobre Tácito e os AnNales}

J. N. Adams (1972), “The Language of the Later Books of Tacitus' Annals", CQ22 350-73.

W. Allen Jr. (1941), "The Political Atmosphere of the Reign of Tiberius", TAPhA 72 1-25.

_ (1947), "The Death of Agrippa Postumus", TAPhA 78 131-139.

_ (1970), “The Leyden MS of Tacitus' Major Works”, TAPhA 101 1-28.

J. E. Allison - J. D. Cloud (1962), "The Lex Julia Maiestatis", Latomus 21 711-731.

C. Ando (1997), “Tacitus, Annales VI: Beginning and End", AJPh 118/2 285-303.

R. Ash (2006), Tacitus. Londres, Bristol Classical Press.

É. Aubrion (1985), Rhétorique et histoire chez Tacite. Metz, Université de Metz.

(1989), “Tacite et la Misericordia”, Latomus 48 383-391.

B. Baldwin (1974), "Themes, Personalities, and Distortions in Tacitus", Athenaeum 52 70-81.

J. P. V. D. Balsdon (1933), “The Successors of Augustus”, G\&R 2/6 161-169.

— (1951), "The 'Murder' of Drusus, Son of Tiberius", CR 1/2 75.

R. Barthes (1964), Essais Critiques. Paris, Éditions du Seuil.

P. Beguin (1951), "Le «Fatum» dans l'oeuvre de Tacite", AC 20 315-334.

— (1953), “La Personalité de l'Historien dans l'Oeuvre de Tacite: son esprit critique et positiviste", AC 22 322-346.

H. W. Benario (1975), An Introduction to Tacitus. Athens, University of Georgia Press.

A. R. Birley (2000), "The Life and Death of Cornelius Tacitus", Historia 49/2 230-247. 
J. Bodel (1999), "Punishing Piso", AJPh 120/1 43-63.

R. Boesche (1987), "The Politics of Pretense: Tacitus and the Theory of Despotism", History of Political Thought 8/2 189-210.

K. R. Bradley (1973), "Tum Primum Revocata Ea Lex", AJPh 94/2 172-181.

C. O. Brink (1952), "Justus Lipsius and the text of Tacitus", JRS $4232-51$.

P. A. Brunt (1984), "The Role of the Senate in the Augustan Regime”, CQ 34/2 423-444.

M. P. Charlesworth (1923), "Tiberius and the Death of Augustus", AJPh 44 145-157.

C. W. Chilton (1955), "The Roman Law of Treason under the Early Principate", JRS 45/1-2 73-81.

E. Cizek (1979), "Sine Ira et Studio et l'Image de l'Homme chez Tacite", StudClas 18 103-113.

(1991), "La Poétique de l'histoire chez Tacite", REL 69 $136-146$.

A. Cooley (1998), "The Moralizing Message of the 'Senatus Consultum de Cn. Pisone Patre'”, Ge̛R 45/2 199-212.

P. L. Corrigan (1993), "A Literary Reading of Tacitus Annals 4.68-70: The Slaying of Titius Sabinus", $R h M$ 136/3-4 $330-342$.

J. Cousin (1951), "Rhétorique et psychologie chez Tacite, un aspect de la deinosis", REL 29 228-247.

F. H. Cramer (1945), "Bookburning and Censorship in Ancient Rome: A Chapter from the History of Freedom of Speech", JHI 6/2 157-196.

P. J. Cuff (1964), “Tacitus, Annals I.72”, CR 14/2 136-137.

S. G. Daitz (1960), "Tacitus' technique of character portrayal", AJPh 81/1 30-52.

C. Damon (1999a), "Relatio vs. Oratio: Tacitus, Ann. 3.12 and the Senatus Consultum de Cn. Pisone Patre", CQ 49 336-38. (1999b), "The Trial of Cn. Piso in Tacitus' Annales and the 
Senatus Consultum de Cn. Pisone Patre: new light on the Narrative Technique", AJPh 120 143-62.

J. Dangel (1991), "Les structures de la Phrase Oratoire Chez Tacite: Étude Syntaxique, Rytmique et Métrique" in $A N R W 3$. II, 33.4. Berlim, Walter de Gruyter 2454-2538.

R. Develin (1983), "Tacitus and Techniques of Insidious Suggestion", Antichthon 17 64-95.

O. Devillers (1994), Lart de la persuasion dans les Annales de Tacite. Bruxelas, Éditions Latomus.

_ (2003), Tacite et les sources des Annales: enquêtes sur la méthode historique. Lovaina, Éditions Peeters.

É. P. Dubois-Guchan (1861), Tacite et son siècle, ou la Société Romaine Impériale, d'Auguste aux Antonins dans ses rapports avec la société moderne. Paris, Didier.

M. Ducos (1977), "La Liberté chez Tacite: droits de l'individu ou conduite individuelle?", BAGB 2 194-217.

Ph. Fabia - P. Wuilleumier (1949), Tacite: L'Homme et L'Oeuvre. Paris, Boivin.

Ph. Fabia (1967 [1893]), Les sources de Tacite dans les Histoires et les Annales, etc. Roma, L'erma di Bretschneider.

M. M. a Frade (2002), "Traição e morte no principado de Tibério" in De Augusto a Adriano: Actas de Colóquio de Literatura Latina. Lisboa, Centro de Estudos Clássicos 469-478.

C. Gill (1983), “The Question of Character-Development: Plutarch and Tacitus", CQ 33 469-487.

K. Gilmartin (1975), "A Rhetorical Figure in Latin Historical Style: The Imaginary Second Person Singular", TAPhA 105 99-121.

I. Gogitore (1991), "La potentia chez Tacite: accusation indirect du Principat”, $B A G B 2$ 158-171.

J. González (1999), “Tacitus, Germanicus, Piso, and the Tabula Siarensis", AJPh 120/1 123-142.

F. R. D. Goodyear (1965), “The Readings of the Leiden Manuscript of Tacitus", CQ 15/2 299-322. 
- (1968), "Development of language and style in the Annals of Tacitus", JRS 58 22-31.

_ (1979), “Imperatoria Nomina (Tac. Ann. 1.3.1)”, CQ 29/1 222-223.

M. L. Gordon (1936), "The Patria of Tacitus", JRS 26/2 145151.

A. M. Gowing (1990), "Tacitus and the Client Kings", TAPhA $120315-331$.

- (2009), "From the annalists to the Annales: Latin historiography before Tacitus" in A. J. Woodman, ed, The Cambridge Companion to Tacitus. Cambridge, Cambridge University Press 17-30.

M. T. Griffin (2009), “Tacitus as a historian” in A. J. Woodman, ed, The Cambridge Companion to Tacitus. Cambridge, Cambridge University Press 168-183.

P. Grimal (1989), “Tacite et les Présages”, REL 67 170-178.

A. R. Hands (1974), "Postremo suo tantum ingenio utebatur", CQ 24 312-317.

G. A. Harrer (1920), “Tacitus and Tiberius”, AJPh 41/1 57-68.

H. Haynes (2003), Tacitus on Imperial Rome: The History of MakeBelieve. Berkeley, University of California Press.

J. Hellegouarch, (1991) "Le Style de Tacite: Bilan et Perspectives" in $A N R W$ 3. II, 33.4. Berlim, Walter de Gruyter 2385-2453.

G. W. Houston (1985), “Tiberius on Capri”, G\&R 32/2 179-196.

T. S. Jerome (1912), "The Tacitean Tiberius: a Study in Historiographic Method”, CPh 7/3 265-292.

L. Jerphagnon (2004), Au Bonheur des Sages. Paris, Hachette.

M. Kaplan (1994 [1979]), "Agrippina semper atrox: a Study in Tacitus' Characterization of Women" in C. Deroux, ed, Studies in Latin Literature and Roman History, vol. VII. Bruxelas, Éditions Latomus 410-417. 
R. Katzoff (1971), “Tacitus, Annales, I.74: The Case of Granius Marcellus”, AJPh 92/4 680-684.

E. Keitel (1981), "Tacitus on the Deaths of Tiberius and Claudius", Hermes 109/2 206-214.

J. M. Kivuila-Kiaku (1995), “Destin, liberté, nécessité et causalité chez Tacite ou la philosophie tacitiéenne de la dignitas bumana", AC 64 111-127.

- (1997), "Causalité historique et philosophie de l'histoire chez Tacite", Latomus 56 829-846.

C. S. Kraus - A. J. Woodman (1997), Latin Historians. Oxford, Clarendon Press.

C. S. Kraus (2009), "The Tiberian hexad" in A. J. Woodman, ed, The Cambridge Companion to Tacitus. Cambridge, Cambridge University Press 100-115.

J. Lacroix (1951), “Fatum et fortuna dans l'oeuvre de Tacite”, REL 29 247-264.

J.-L. Laugier (1969), Tacite. Paris, Éditions du Seuil.

A. D. Leeman (1963), Orationis Ratio: the stylistic theories and practice of the Roman orators, historians and philosophers. Amesterdão, Adolf M. Hakkert.

_ (1973), "Structure and Meaning in the Prologues of Tacitus”, YClS 23 169-208.

E. Löfsted (1948), "On the Style of Tacitus", JRS 38/1-2 1-8.

— (1958), Roman Literary Portraits. Oxford, Clarendon Press.

D. Longrée (1991), "La Phrase à Rallonge Chez Tacite" in $A N R W$ 3. II, 33.4. Berlim, Walter de Gruyter 2539-2580.

T. J. Luce (1991), "Tacitus on "History's Highest Function": praecipuum munus annalium (Ann. 3.65)" in ANRW3. II, 33.4. Berlim, Walter de Gruyter 2904-2927.

C. S. Mackay (2003), “'Questiones Pisonianae’: Procedural and Chronological Notes on the 'S. C. de Cn. Pisone Patre”, HSPh 101 311-370. 
A. Malissard (1998), “Tacite et l'espace tragique”, Pallas 49 211-224.

S. J. V. Malloch (2004), "The End of the Rhine Mutiny in Tacitus, Suetonius, and Dio", CQ 54/1 198-210.

C. Marchesi (1955), Tacito. Milão, Casa Editrice Giuseppe Principado.

J. Marincola (1999a), "Genre, convention, and innovation in greco-roman historiography" in C. S. Kraus, ed, The Limits of Historiography: Genre and Narrative in Ancient Historical Texts. Leiden, Brill 281-324.

(1999b), “Tacitus' Prefaces and the Decline of Imperial Historiography", Latomus 58 391-404.

A. J. Marshall (1975), “Tacitus and the governor's lady: a note on Annals 3.33-34", G\&R 22 11-18.

R. H. Martin (1946), "-ere and -erunt in Tacitus", CR 60/1 17-19.

- (1953), "Variatio and the development of Tacitus' style", Eranos 51 89-96.

(1955), "Tacitus and the Death of Augustus", CQ 5/1-2 123-128.

(1981), Tacitus. Londres, Bristol Classical Press (reimpr 2001).

- (1990), "Structure and Interpretation in the Annals of Tacitus" in $A N R W 1$. II, 33.2. Berlim, Walter de Gruyter 1500-1581.

G. Maurand - M. Monbrun (1976), "Approche linguistique d'un texte latin: Tacite Annales 1.65", Pallas 23 75-89.

H. Y. McCulloch Jr. (1984), Narrative Cause in the Annals of Tacitus. Königstein, Verlag Anton Hain.

_ (1991), "The Historical Process and Theories of History in Annals and Histories of Tacitus", ANRW 3. II, 33.4. Berlim, Walter de Gruyter 2928-2948.

R. Mellor (1994), Tacitus. Nova Iorque, Routledge. 
A. Michel (1959), "La causalité historique chez Tacite", REA 61 96-106.

(1966), Tacite et le destin de l'empire. Paris, Arthaud.

(1981), "Le Style de Tacite et sa Philosophie de l'Histoire", Eos 49 283-292.

C. C. Mierow (1939), "Tacitus the Biographer", CPh 34/1 36-44.

N. P. Miller (1964), "Dramatic speech in Tacitus", AJPh 85 279-296.

_ (1968), “Tiberius speaks: An Examination of the Utterances Ascribed to Him in the Annals of Tacitus", AJPh 89 1-19.

_ (1969), "Style and Content in Tacitus" in T. A. Dorey, ed, Tacitus. Londres, Routledge.

_ (1977), “Tacitus' Narrative Technique”, G\&R 24 13-22.

A. C. Miravalles (2001), "Tacito: furor ante oculos", AC 70 87-96.

J. Moles (1998), “Cry Freedom: Tacitus Annals 4.32-35”, Histos 2 [disponível em http://www.dur.ac.uk/Classics/histos/1998/ moles.html, acedido a 3 de Maio de 2010].

F. G. Moore (1903), "Studies in the Tacitean ellipsis: descriptive passages”, TAPhA 34 5-26.

(1923), "Annalistic Method as Related to the Book Divisions in Tacitus", TAPhA 54 5-20.

R. Morello (2006), "A Correspondence Course in Tyranny: The Cruentae Litterae of Tiberius", Arethusa 39 331-354.

L. Morgan (1998), "Tacitus, Annals 4.70: An Unappreciated Pun", CQ 48/2 585-587.

E. O'Gorman (2000), Irony and Misreading in the Annals of Tacitus. Cambridge, Cambridge University Press.

S. P. Oakley (2009), "Style and language" in A. J. Woodman, ed, The Cambridge Companion to Tacitus. Cambridge, Cambridge University Press 195-211.

R. P. Oliver (1951), "The First Medicean MS of Tacitus and the 
Titulature of Ancient Books", TAPhA 82 232-261.

V. E. Pagán (1999), "Beyond Teutoburg: Transgression and Transformation in Tacitus' Annales 1.61-62", CPh 94 302-320.

(2005), Conspiracy Narratives in Roman History. Austin, University of Texas Press.

A. E. Pappano (1941), "Agrippa Postumus”, CPh 36/1 30-45.

C. Pelling (2009), "Tacitus' personal voice" in A. J. Woodman, ed, The Cambridge Companion to Tacitus. Cambridge, Cambridge University Press 147-167.

J. Percival (1980), "Tacitus and the Principate", G\&R 27 119-133.

J. Perret (1954), "La Formation du Style de Tacite", REA 56 90-120.

P. Perrochat (1936), "Lévolution d'un Procédé de Style Chez Tacite", REL 14 43-48.

M. ${ }^{a}$ C. C.-M. de S. Pimentel (2004), "Virtus ipsa: o retrato literário nos Annales de Tácito” in A. Jiménez et al., eds, $O$ retrato literário e a biografia como estratégia de teorização politica. Coimbra, Imprensa da Universidade 65-82.

- (2006), "A Noite e as Trevas na Obra de Tácito" in M. ${ }^{\mathrm{a}}$ de F. Reis, ed, Rumos e Escrita da História. Estudos em Homenagem a A. A. Marques de Almeida. Lisboa, Ediçóes Colibri 487-506.

S. B. Platner (1888), "Gerunds and Gerundives in the Annals of Tacitus", AJPh 9 464-472.

D. S. Potter (1999), "Political Theory in the 'Senatus Consultum Pisonianum”, AJPh 120/1 65-88.

K. Quinn (1963), Latin Explorations, Critical Studies in Roman Literature. Londres, Routledge.

C. Rambaux (1972), “Germanicus ou La Conception Tacitiéenne de L'Histoire”, AC 41 174-199.

J. S. Reid (1921), “Tacitus as a Historian”, JRS 11 191-199. 
J. S. Richardson (1997), "The Senate, the Courts, and the SC de Cn. Pisone patre", CQ 47/2 510-518.

R. L. Roberts (1936), “Tacitus' Conception of the Function of History", G\&R 6/16 9-17.

R. S. Rogers (1931a), "The Conspiracy of Agrippina”, TAPhA 62 141-168.

—_ (1931b), "Lucius Arruntius", CPh 26/1 31-45.

_ (1952), "A Tacitean Pattern in Narrating Treason Trials", TAPhA 83 279-311.

_ (1959), "Treason in the Early Empire", JRS 49/1-2 90-94.

— (1965), “The Case of Cremutius Cordus", TAPhA 96 351-359.

D. O. Ross Jr. (1973), “The Tacitean Germanicus”, YClS 23 209-227.

L. W. Rutland (1978), "Women as Makers of Kings in Tacitus' Annals", CW72 15-29.

— (1987), “The Tacitean Germanicus: Suggestions for a Reevaluation”, RhM 130 153-164.

S. H. Rutledge (1999), "Delatores and the Tradition of Violence in Roman Oratory”, AJPh 120/4 555-573.

I. S. Ryberg (1942), “Tacitus' art of Innuendo”, TAPhA 73 383-404.

M. D. Verdejo Sánchez (2001), "Propaganda y Deformación de la Historia en Roma. Tácito y la Utilización de Rumores" in A. P. Jiménez - C. C. Andreotti, eds, La Verdad Tamizada: Cronistas, Reporteros e Historiadores ante su Público. Madrid, Ediciones Clásicas 107-138.

F. E. Santoro L'hoir (2006), Tragedy, Rhetoric, and the Historiography of Tacitus' Annales. Ann Arbor, University of Michigan Press.

B. Segura-Ramos (1998), "Tacite ou la tragédie du pouvoir", Pallas 49 225-235.

I. Shatzman (1974), “Tacitean Rumours”, Latomus 33 549-578. 
D. C. A. Shotter (1965), "Three Problems in Tacitus' Annals I", Mnemosyne 18 359-361.

—_ (1966a), "Ea Simulacra Libertatis", Latomus 25/2 265-271.

_ (1966b), "Elections under Tiberius", CQ 16/2 321-332.

- (1966c), "Tiberius and the Spirit of Augustus", G\&R 13/2 207-212.

— (1967a), “The Starting-Dates of Tacitus' Historical Works”, CQ 17/1 159-163.

— (1967b), "Three Notes on Tacitus Annales 1 and 2", CPh 62/2 116-118.

_ (1968), “Tacitus, Tiberius and Germanicus”, Historia 17 194-214.

__ (1972), "The Trial of C. Junius Silanus", CPh 67/2 126-131.

P. Sinclair (1990), “Tacitus' Presentation of Livia Julia, Wife of Tiberius' Son Drusus", AJPh 111/2 238-256.

— (1991a), “These Are My Temples in Your Hearts' (Tac. Ann. 4.38.2)”, CPh 86/4 333-335.

- (1991b), "Rhetorical Generalizations in Annales 1-6. A Review of the Problem of Innuendo and Tacitus' Integrity" in $A N R W$ 3. II, 33.4. Berlim, Walter de Gruyter 2795-2831.

— (1995), Tacitus the Sententious Historian: A Sociology of Rhetoric in Annales 1-6. Pensilvânia, Pennsylvania State University Press.

R. Syme (1939), The Roman Revolution. Oxford, Oxford University Press (reimpr 2002).

(1958), Tacitus. Oxford, Oxford University Press (reimpr 1997).

— (1970), Ten Studies in Tacitus. Oxford, Oxford University Press.

— (1984), Roman Papers, vol. III. Ed. A. R. Birley. Oxford, 
Oxford University Press.

— (1988), Roman Papers, vol. IV. Ed. A. R. Birley. Oxford, Oxford University Press.

— (1991), Roman Papers, vol. VI. Ed. A. R. Birley. Oxford, Oxford University Press.

R. G. Tanner (1969), "Tacitus and the Principate”, G\&R 16/1 95-99.

R. J. Tarrant - M. Winterbottom (1983), “Tacitus” in L. D. Reynolds, ed, Texts and Transmission: A Survey of the Latin Classics. Oxford, Clarendon Press 406-411.

H. W. Traub (1953), “Tacitus' use of ferocia”, TAPhA 84 250-61.

C. J. Tuplin (1987), "The False Drusus of AD 31 and the Fall of Sejanus", Latomus 46/4 781-805.

B. L. Ullman (1942), "History and Tragedy", TAPhA 73 25-53.

B. Walker (1952), The Annals of Tacitus: A Study in the Writing of History. Manchester, Manchester University Press.

P. A. Watson (1995), Ancient Stepmother: Myth, Misogyny and Reality. Leiden, Brill.

R. E. Wedd (1909), “Tacitus, Ann. IV.33”, CR 23/2 42-43.

K. Wellesley (1954), “Can you Trust Tacitus?”, G\&R 1 13-35.

D. B. Wharton (1997), "Tacitus' Tiberius: The State of the Evidence for the Emperor's ipsissima uerba in the Annals", AJPh 118/1 119-125.

H. W. White (1932), “Tacitus Reconsidered”, G\&R 2/4 38-46.

D. Whitehead (1979), "Tacitus and the Loaded Alternative", Latomus 38 474-495.

S. E. Wood (1999), Imperial Women: A Study in Public Images, 40 $b C-a D$ 68. Leiden, Brill.

A. J. Woodman, (1998), Tacitus Reviewed. Oxford, Clarendon Press. (2002), "Not a Funeral Note: Tacitus, Annals 1.8.5-6”, CQ 
$52 / 2629-632$.

(2006a), "Mutiny and Madness: Tacitus Annals 1.16-49", Arethusa 39 303-329.

_ (2006b), "Tiberius and the Taste of Power: the year 33 in Tacitus", CQ 56/1 175-189.

_ (2009), "Tacitus and the contemporary scene" in A. J. Woodman, ed, The Cambridge Companion to Tacitus. Cambridge, Cambridge University Press 31-43. 


\section{INDEX NOMINVM}

Afrânio, Lúcio: 169

Agripa Póstumo: 46, 47, 49n., 54n., 55-60, 62n., 139, 163n., $164 n$.

Agripina Maior (esposa de Germânico): 7, 32, 38, 64, 65n., 70-72, 77, 83, 87, 96, 142, 144, 145n., 148, 149, 153, 155, 156, 157, 161, 162, 164

Agripina Menor (filha de Germânico): 32, 83, 145n.

Aneu Séneca, Lúcio: 31, 33, 165n.

Antónia (filha de Cláudio): 32

Antónia (mãe de Germânico e de Cláudio): 82, 140, 149

António, Marco: 42, 44, 82, 83, 140

Aprónio, Lúcio: 134

Armínio (líder germano): 25, 62n., 97n.

Arrúncio, Lúcio: 86, 102

Artabano (rei da Pártia): 8n., 90-91

Asínio Agripa: 166

Asínio Galo, Gaio: 86n., 102, 169n.

Asínio Polião, Gaio: 169

Augusta, $v$. Lívia Augusta

Augusto: 3, 5, 7, 26, 38, 40, 42-50, 51-52, 54-56, 58-59, 65, 66, 70, 74-75, 76, 81, 82, 83, 86, 96n., 97, 100n., 103, 123, 136, 140, 142, 143, 144n., 145, 147, 151, 164n., 165n., 168n., 169, 174, 175

Aurélio Cota Messalino, Marco: 134, 169n.

Aurélio Cota, Marco: 108

Bibáculo, $v$. Fúrio Bibáculo

Bruto, $v$. Júnio Bruto

Calígula, $v$. Gaio César

Calpúrnio Pisão, Gaio (conspirador do tempo de Nero): 31, 32

Calpúrnio Pisão, Gneu (governador da Síria): 7, 33, 38, 41, 62, 63, 64n., 85-96, 98-110, 116, 117, 134, 139n., 163n., 164n., 167, 171, 174, 175, 176

Calpúrnio Pisão, Gneu (pai do anterior): 86n., 108

Calpúrnio Pisão, Lúcio (o áugure): 102, 109, 134

Calpúrnio Pisão, Marco (filho de Gneu Calpúrnio Pisão): 98, 89, 108

Calusídio: 68, 76

Cássio Longino, Gaio (tiranicida): 42-43, 45, 166, 168, 169, 170

Cássio Severo: 168

Catão, v. Pórcio Catão

Catulo: 169

Cecílio Cipião, Quinto: 169

Cecílio Metelo Crético Silano, Quinto: 85

Cecina Severo, Aulo: 66n., 69n., 78, 140n.

César, Gaio: 52-53, 54, 143, 150

César, Lúcio: 52-53, 54, 143

Cipião, v. Cecílio Cipião

Cláudio Druso (pai de Germânico): 51, 52, 54, 76, 80, 81, 84, 140, 175 
Cláudio Marcelo, Marco (sobrinho de Augusto): 51, 52n., 84, 175

Cláudio Nero, Tibério (pai do imperador): 140

Cláudio: 3, 27, 33, 63, 119n., 140n., 147

Clúvio Rufo: 31

Comício Poliāo: 129

Corbulão, $v$. Domício Corbulão

Cremúcio Cordo: 7, 25n., 29, 37n., 117, 118, 165-171, 177

Crético Silano, v. Cecílio Metelo Crético Silano

Domício Célere (amigo de Pisão): 41n., 87n., 98-99

Domício Corbulão, Gneu: 32

Druso César (filho de Germânico): 83, 151, 154, 163, 164

Druso César (filho de Tibério): 7, 38, 65n., 73n., 81, 100n., 115, 116-117, 118, 136-139, 140-147, 149, 150, 153, 154, 175, 176

Druso Claudiano, Marco: $123 \mathrm{n}$.

Druso Libão, Marco: $123 \mathrm{n}$.

Élio Sejano, Lúcio: 7-8, 29, 38n., 39, 101n., 115-118, 124, 137-144, 145n., 146-151, 153-154, 156, 157, 159, 160n., 161, 162, 163-164, 166, 167n., 174, 175,176

Emílio Lépido, Marco (cônsul do ano 6): 102

Emílio Lépido, Marco (triúnviro): 42, 43

Escribónia: 123

Escribónio Libão Druso, Marco: 7, 99, 100n., 101, 102n., 106, 117, 120-134, 163n., 167, 168n., 169n., 171, 176

Estertínio, Lúcio: $83 n$.

Fábio Máximo, Paulo: 47-48

Fábio Rústico: 31, 33

Fírmio Cato: 122-123, 124, 129n., 133

Flaco Vesculário: 123

Fonteio Agripa: 128-129

Fulcínio Triāo, Lúcio: 100, 125, 135, 176

Fúrio Bibáculo: 169

Gaio César Calígula: 27, 51, 70-71, 65n., 72, 77, 83, 151n.

Germânico: 7, 19n., 33, 38, 41, 49n., 56, 61-110, 115n., 116, 118, 120, 122n., 134, 136, 138, 139, 140n., 141n., 142, 143, 148, 151, 153-155, 157, 160, 161, $162-163,175,176$

Hírcio, Aulo: 44

Júlia (esposa de Druso, filho de Germânico): 151

Júlia (filha de Augusto): 52, 55

Júlia Drusila (filha de Germânico): 83

Júlia Livila (filha de Germânico): 83

Júlio César, Gaio: 43, 75, 167, 169

Júnio (mago): 125

Júnio Bleso, Quinto: 70n.

Júnio Bruto, Marco (tiranicida): 42-43, 45, 166, 168-170

Laciar, Lacínio: 156-158, 159, 160, 162

Lêntulo, Gneu: 134

Lépido, $v$. Emílio Lépido

Ligdo: 138, 139n., 153, 154, 176

Lívia Augusta: 7, 52, 62n., 87, 91n., 96n., 98, 99, 105, 106, 107, 108, 109, 
123n., 141, 142, 143, 149, 154, 155, 162n., 168n., 175

Lívia Júlia: 7, 101, 117, 136, 140-146, 151-152, 153, 154, 155, 163n., 175

Livila, $v$. Lívia Júlia

Livineio Régulo, Marco: 102

Lívio, Tito: 3, 18n., 20n., 25n., 141n., 169

Lólio, Marco: 45

Macrão, Quinto Névio Cordo Sutório: 8

Marcelo Esernino: 102

Márcia: 47-48

Marobóduo (rei dos Suevos): 31

Martina: 108, 139n.

Munácio Planco, Lúcio: 70

Nero (imperador): 3, 27, 32, 37n., 50, 57n., 83, 119

Nero César (filho de Germânico): 7n., 83, 85, 154, 160, 163-164

Octávia (irmã de Augusto): 140

Ópsio, Marco: 156, 161

Pansa, $v$. Víbio Pansa

Pápio Mutílio, Marco: 134

Petílio Rufo: 156

Pinário Nata: 166

Plancina: 7, 63, 86-87, 89, 91, 92n., 94, 95, 100, 105-106, 108-109, 110, 139n., 174, 175

Plínio, Gaio (Plínio-o-Velho): 2, 31-32

Pompeia: 123

Pompeio Magno, Gneu: 42n., 116, 121, 123, 169

Pompeio, Sexto: 42, 43, 102, 123

Pórcio Catão, Marco (o Censor): 169

Pórcio Catão, Marco: 156

Proculeio, Gaio: 150

Quintílio Varo, Públio: 19n., 45, 83n.

Quirínio, v. Sulpício Quirínio

Salústio Crispo, Gaio: 20, 25n., 117n.

Sátrio Secundo: 166

Sêncio Saturnino, Gneu: 98

Séneca, $v$. Aneu Séneca

Sílio Aulo Cecina Largo, Gaio: 7, 66n., 155, 162 n.

Sósia Gala: 7, 162n.

Sulpício Quirínio, Públio: 131

Terêncio, Marco: 29

Tibério: passim

Tício Sabino: 7, 86n., 117, 134, 155-162, 166n., 176

Túlio Cícero, Marco: 19-23, 169

Urgulânia: 109n.

Valério Messala Corvino, Marco: 169

Valério Messalino: 169n.

Verânio, Quinto: 100

Víbio Pansa, Gaio: 44

Víbio Sereno, Gaio: 129

Vinício, Públio: 102 
Vipsânia: 136, 140n.

Vipsânio Agripa, Marco: 51, 52, 54n., 140n., 143, 150

Vitélio, Aulo: 19n.

Vitélio, Públio: 100 


\section{INDEX LOCORVM}

\section{Aristóteles}

Poetica

1449b: 15

1451b: 19

1459a: 15n., 23

\section{Cícero}

Ad Familiares

5.12.4: 22

5.12.5: 21 n., 22

5.12.6: 20n., 22

De Legibus

1.2.5: 19n., 20n., 21n., 22n., 23n.

1.2.6-7: $20 \mathrm{n}$.

1.2.6: $21 \mathrm{n}$.

1.3.8-9: $23 \mathrm{n}$.

De Oratore

2.12.51: $20,22 \mathrm{n}$.

2.12.52-53: 20-21

2.12.54: 21

2.13.54: 21

2.13.55: 21

2.13.59: 21

2.15.62: 22

2.15.63: 22, 23n.

Philippicae

11.11.30: 93n.

Cornélio Tácito

Agricola

2-3: 2

2.1: $171 \mathrm{n}$.

2.3: $171 \mathrm{n}$.

2.4: 173

3.1: $80 \mathrm{n}$.

10.3: $31 \mathrm{n}$.

45: 2

45.5: 2

Annales

1.1.1: 26-27, 42, 43, 46, 80n.

1.1.2: 25n., 26-27, 45, 127n.

1.1.3: $26,27-28$

1.2.1-4.1: 26n., 42n.

1.2.1: 42, 43, 45, 46, $144 \mathrm{n}$.

1.2.2: 46

1.3.1-2: $51-52$
1.3.1: $51,54,143$

1.3.3: 52-55, 56, 143

1.3.4: 46, 47, 55, 58, 60, 91n.

1.3.5: 66, 81, 136

1.3.6: 44,46

1.3.7: 26,46

1.4.1: 45 n., 46

1.4.2-5.4: 26n.

1.4.2: $46,56-57$

1.4.3: 50, 57, 59, 60, 103n.

1.4.4: 60

1.5.1-2: $164 \mathrm{n}$.

1.5.1: 46, 47, 141, 143

1.5.2: $47-48$

1.5.3-4: 49

1.5.4: 49,50

1.6.1: 26n., 49n., 57-59

1.6.2: $53,59,62$ n.

1.7.1: 45

1.7.6-7: 82

1.7.6: 80,137

1.7.7: 46

1.8.2: 45

1.8.3: $102 \mathrm{n}$.

1.8.4: $169 \mathrm{n}$.

1.8.6: 46

1.9.1: 97

1.9.3: 43 n., 44

1.9.4: 43,45

1.9.5: 27 n., 46

1.10.1: 43n., 45, 46

1.10.2: 44, 45, 46, 53n.

1.10.3: $43,44,46$

1.10.4: 45

1.10.5: 45,53

1.10.7: 59n., 80n., 81

1.11.2: $103 n$.

1.12.1: 43

1.12.6: $169 \mathrm{n}$.

1.13.2: 96n.

1.13.3: 86

1.13.4: 89n.

1.14.1: 109

1.14.3: 69 


1.14.4: $66 n$.
1.15.1: $128 n$.
1.16.1-30.5: $65 n ., 136$
1.17.1-6: 66
1.24.2: 116,137
1.29.1: $73 n$.
1.29.2: $46 n$.
1.29.4: 32
1.31.1-1.51: 136
1.31.1: 66,67
1.31.2: 66 n.
1.31.3: $66 n$.
1.31.4: $66,75 n$.
1.33.1: $38 n ., 62 n ., 66 n ., 82 n ., 143$
1.33.2: 80
1.33.3: $53,96 n$.
1.34.1: 66
1.34.2: 66,67
1.34.3: 66,67
1.34.4: $66,75 n ., 94 n$.
1.35.1-5: 66
1.35.1: 67
1.35.3: $67-68$
1.35.5: 68,76
1.36.1: $68 n$.
1.36.2: 69
1.36.3: 69
1.37.1: 69,78
1.39.1: 69
1.39.2: 69
1.39.3: $69-70$
1.40.1-2: 63,70
1.40.3: $70-71,83,96 n$.
1.40.4: 71
1.41.1: 71
1.41.2: $72,77 n$.
1.41.3: 72
1.42.1-43.4: $73,94 n$.
1.42.1: $73-74,75 n$.
1.42.2-43.3: $73 n$.
1.42.2: 74
1.42.3-4: 66
1.42.3: 75
1.42.4: 75
1.43.1-3: 76
1.43.3-4: $73 n$.
1.43.3: 77
1.43.4: $73 n ., 76$
1.44.1: $76-77$

1.44.4: 68n., 69, 77

1.45.1: 78

1.45.2: 78

1.47.1-2: $38 \mathrm{n}$.

1.47.3: $38 \mathrm{n}$.

1.48.1: 78

1.48.2: 78

1.48.3: 78

1.49.1: 78-79

1.49.2: $68 \mathrm{n}$.

1.49.3: 68n., 79

1.51.1: 79, 85

1.51.2: 63

1.51.3: 79

1.51.4: 79

1.52.1-3: 136

1.52.1: 70

1.53.1: $53 \mathrm{n}$.

1.53.2: 58

1.55.1: 85

1.59.5: $62 \mathrm{n}$.

1.60.2: 64

$1.61 .1-62.2: 83$

1.62.1: 64

1.63.2: $51 \mathrm{n}$.

1.69.1: $71 \mathrm{n}$.

1.69.2: 31

1.69.4: 72, $154 \mathrm{n}$.

1.69.5: 103n., 116

1.72.2-74.5: 121

1.72.3: $168 \mathrm{n}$.

1.74.5: 86

1.75.1: 30n.

1.77.3: 66n.

1.78.2: $45 \mathrm{n}$.

1.81.1: 31, 32

2.1.2: 90

2.3.1: $85 \mathrm{n}$.

2.4.1: $53 \mathrm{n}$.

2.4.3-5.1: 85 n.

2.4.3: 90

2.7.3: $64 \mathrm{n}$.

2.12.1: 63, 79n.

2.13.1: 89n., 90

2.24.2: 68

2.26.2: 85

2.26.4: $97 \mathrm{n}$.

2.26.5: 85

2.27.1: 120-121, 128n., 133, 135, 168n. 
2.27.2: 121-123, 133

2.28.1: $123,130-131$

2.28.2: 124-125, 127n., 129n., 167

2.28.3: $101,125,128$

2.29.1: 102n., 126, 128

2.29.2: $126-128$

2.30.1: 128,129

2.30.2: 100n., 129-130

2.30.3: 89n., 130-131, 168n.

2.30.4: 131

2.31.1: 126n., 131-132, 133

2.31.2: 132,133

2.31.3: 133

2.32.1-2: 134

2.32.1: 134, 169n.

2.32.2: 134-135

2.32.3: $122 \mathrm{n}$.

2.33.3: 30

2.34.2-4: 109n.

2.35.1: 86

2.39.1-40.3: $164 n$.

2.39.1: 58

2.40.1: $132 \mathrm{n}$.

2.40.2: 32

2.41.2: $120 \mathrm{n}$.

2.41.3: 52n., 83n., 84

2.42.1: 84,164

2.42.2: $53 \mathrm{n}$.

2.42.3: $53 \mathrm{n}$.

2.43.1: 63,85

2.43.2-3: 87

2.43.2: $85-86$

2.43.3: 108

2.43.4: 87, 95 n.

2.43.5: 83 .

2.43.6: 140n., 144

2.46.5: $38 \mathrm{n}$.

2.50.1-2: $168 \mathrm{n}$.

2.51.2: 30

2.53-2.61: 136

2.53.1-55.5: $64 n$.

2.53.1: 136

2.53.2: 38n., 82, 83n.

2.53.3: 88

2.54.1: 83

2.54.2-4: 84

2.54.2: 63

2.54.4: 89n.

2.55.1: 88
2.55.2: 63, 89n.

2.55.3: 63n., 89n.

2.55.6: 47n., 63n., 87

2.57.1-2: 88

2.57.1: 88, 99

2.57.2: 38n., 89

2.57.3-4: 90

2.57.3: 89-90

2.57.4: 63n., 91

2.58.1: 90

2.58.2: 91

2.59: 63

2.59.2: 66n.

2.59.3: $64,83 n$.

2.60.1: 63n.

2.61.2: 3, 38n.

2.62-2.63: 136

2.63.3: 31

2.64.1: 63,136

2.69.1-2: 91

2.69.1: 63n., 92

2.69.2: 91,92

2.69.3: 91, 92, 136

2.70.1: 89n., 93

2.70.2: 92,93

2.70.3: $87 \mathrm{n}$.

2.70.4: 128 n.

2.71.1: 63, 84n., 94, 103n., 107n.

2.71.2: $95,107 \mathrm{n}$.

2.71.3: 95 n.

2.71.4: 83, 94, 95, 142

2.71.5: 94,96

2.72.1: 95n., 96, 142n.

2.72.2: 89n., 97, 99n.

2.73.1-2: 97

2.73.1: 79

2.73.2-3: $97-98$

2.73.2: 83n., 142

2.73.3: $80 \mathrm{n}$.

2.73.4: 110

2.74.1: 87n., 98

2.74.2: 108

2.75.1: 56, 96n.

2.75.2: 92n., 100n.

2.76.1: 87n., 98

2.76.2-3: 98

2.76.2: 92n., 99

2.76.3: 98

2.77: 98 
2.77.1: $87 \mathrm{n}$.

2.77.3: 41n., 99, 101, 106

2.78.1: 99

2.79.5: $87 \mathrm{n}$.

2.80.1-81.3: 99

2.80.1: 99n.

2.80.3: 87n., 99n.

2.81.1: $140 \mathrm{n}$.

2.82.1: $108 \mathrm{n}$.

2.82.2: 80 n.

2.82.3: 153 n.

2.82.4: 49 n.

2.82.5: 50n.

2.83.3: $73 \mathrm{n}$.

2.84.1: 140n., 144

2.84.2: 148n., 153n.

2.86.1: 129

2.88.1: 32

2.88.2: $97 \mathrm{n}$.

2.88.3: 25

3.2.2: 169 n.

3.3.2: $31,82,83 \mathrm{n}$.

3.3.3: 33

3.4.2: 83

3.6.2: $53 \mathrm{n}$.

3.7.1: $98 \mathrm{n}$.

3.7.2: 38n., 108

3.8.1: $100 \mathrm{n}$.

3.9.2: $100 \mathrm{n}$.

3.9.3: $100 \mathrm{n}$.

3.10.1-2: 101

3.10.1: 100, 101, 106

3.10.2: 105

3.10.3: 102

3.11.2: 103, 105

3.12.1: 85,103

3.12.2-3: 104

3.12.2: $87 \mathrm{n}$.

3.12.3: 89,101

3.12.6: 101

3.13.1: 86n., 100n.

3.14.1: 101,105

3.14.2: 105

3.14.3: 105

3.14.4: $105 \mathrm{n}$.

3.15.1: 105, 106, 108n.

3.15.2: 103n., 106, 107, 167

3.15.3: 106-107

3.16.1:32, 95n., 116
3.16.2: 107

3.16.3: 87n., 89, 103, 107

3.16.4: 108

3.17.1: 108

3.17.4: 108, 109

3.18.1: 108

3.19.2: 100n., 109, 110, 139

3.22.1: 120n., 122n.

3.25.2-28.2: $43 n$.

3.25.2: $118 \mathrm{n}$.

3.29.4: 138,147

3.30.2: 25 n.

3.30.3: 58

3.30.4: $30 \mathrm{n}$.

3.31.1: 136

3.33.1-35.3: 109n., 140n.

3.33.2: $141 \mathrm{n}$.

3.33.3: 109n.

3.34.6: 140-141, 142, 146n.

3.35.1: $102 \mathrm{n}$.

3.38.1: 118

3.39.4: 146 n.

3.43.5-6: 136

3.47.2: $38 \mathrm{n}$.

3.48.1: $53 \mathrm{n}$.

3.48.2: $38 \mathrm{n}$.

3.49-51: 134

3.56.2: $27 \mathrm{n}$.

3.56.3: 136

3.56.4: 136

3.64.2: $103 \mathrm{n}$.

3.65.1-3: 28-29

3.65.1: 177

3.65.3: 124

3.67.3: 131n.

3.72.3: 116,138

3.76.2: 166n.

4.1.1: 38n., 115, 142

4.1.2: 115, 117, $137 \mathrm{n}$.

4.1.3: 115, 117, 151

4.2.1: 138

4.2.2: 138

4.2.3: 115

4.3.1: 142-143, 154

4.3.2: 137,143

4.3.3: 140n., 143-146, 149

4.3.4: 145, 150, 164n.

4.3.5: 146

4.4-6: $115 n$. 
4.4.2: $38 \mathrm{n}$.

4.4.3: 29, 38n.

4.6.1: 29

4.7-8: 137

4.7.1: $115,137,143$

4.7.2: 137-138, 146n., 147

4.7.3: 138,145

4.8.1: 136, 138

4.8.2: 138-139

4.8.3-5: 139

4.9.1: 139

4.10.1: 32, 33

4.10.2-11.3: 139

4.10.2: 138, 141n., 145

4.11.1: 32

4.11.2: 137n., 138n.

4.12.1: 153

4.12.2: 148n., 153, 154

4.12.3: 154

4.12.4: $162 \mathrm{n}$.

4.13.2: 129

4.17.1: $154 \mathrm{n}$.

4.17.2: 155

4.17.3: 161,162

4.18.1-20.4: 162n.

4.18.1: 155, 160n.

4.19.1: 155

4.20.4: 169n.

4.21.1: $38 \mathrm{n}$.

4.21.3: 168n.

4.28.1-30.1: 129

4.29.4: 129

4.30.2: 118 n.

4.30.3: 118,135

4.31.4: $38 \mathrm{n}$.

4.32.1: $26,38 \mathrm{n}$.

4.33.3: 28,119

4.34.1: 37n., 166, 168

4.34.2: 118, 166-168, 171

4.34.3: $25 \mathrm{n}$.

4.35.1: 170

4.35.2: 170

4.35.3: 170

4.35.4: 29,171

4.35.6-7: 165

4.37.2-38.3: 171

4.37.2: 171

4.39.1:38n, 145n, 146, 149,150,151,153n.

4.39.2: 138, 147, 148n.
4.39.3: 147, 151n.

4.39.4: 147-148, 149

4.40.1-2: 148-149

4.40.1: 101n., 150

4.40.2: 140 n.

4.40.3: 149

4.40.4-5: 150

4.40.4: 140n., 149-150

4.40.5: 138,150

4.40.6: 149n., 150, 151

4.40.7: 143, 151

4.41.1: $138 \mathrm{n}$.

4.41.2: 39

4.49.3: $162 \mathrm{n}$.

4.50.6: $132 \mathrm{n}$.

4.52.1: $164 \mathrm{n}$.

4.52.2: 83, 96n.

4.53.1: 96 n.

4.53.2: 32

4.57.1-2: $103 \mathrm{n}$.

4.57.1: 151

4.57.3: 33

4.58.2: $122 \mathrm{n}$.

4.59.3: 163

4.60.1-2: 163

4.60.2-3: 163-164

4.60.2: $163 n$.

4.65.6: 32

4.68-70: 155

4.68.1: 156, 158n., 160n.

4.68.2-70.4: 155

4.68.2: 156, 159n.

4.68.3: 157, 159n., 160

4.68.4: 158, 160, 162

4.69.1: 158

4.69.2: 157n., 159, 162

4.69.3: 159, 160-161

4.70.1-2: 160

4.70.1: 156, 159n., 160

4.70.3: 156

4.70.4: 160

4.71.1: 37n., 111, 159n., 161

4.71.3: $103 n$.

4.73.2: $51 \mathrm{n}$.

4.74.3: 156n.

5.1: $123 \mathrm{n}$.

5.3.2: 169 n.

5.9.2: 32

5.10.1-2: 164n. 


\begin{tabular}{|c|c|}
\hline 5.10.1: 46n. & 13.1.1: $57 \mathrm{n}$. \\
\hline 6.2.1: 145,152 & 13.9.3: $37 \mathrm{n}$. \\
\hline 6.2.5: $128 \mathrm{n}$ & 13.17.2: 32 \\
\hline 6.2.6: $128 \mathrm{n}$ & 13.20.2: 31,33 \\
\hline 6.4.1:38n., 135, 162n. & 13.23.1: $120 \mathrm{n}$. \\
\hline 6.5.1-7.1: 169n. & 13.26.2: 30 \\
\hline 6.6: 8n. & 13.31.1: 29, 31 \\
\hline 6.6.1: 31 & 13.32.2: 38n. \\
\hline $6.7 .5: 29$ & 13.33.1: 38n. \\
\hline 6.8.2: $117,147 \mathrm{n}$. & 13.49: 37n. \\
\hline 6.8.4: $103 \mathrm{n}$ & 13.57.6: 132n. \\
\hline 6.8.5: 166n. & 14.2.1-2: 31 \\
\hline 6.10.3: $128 \mathrm{n}$. & 14.2.2: 32 \\
\hline 6.16.2: 8n. & 14.8.5: 83n. \\
\hline 6.19.1: 120n. & 14.9.3: $122 \mathrm{n}$. \\
\hline 6.19.4: 132n. & 14.12.1:37n. \\
\hline 6.20.2: $122 \mathrm{n}$. & 14.29.1: 38n. \\
\hline 6.21.1: 8n. & 14.48.3-49.3: 37n. \\
\hline 6.22.1: 46n. & 14.50.2: $171 \mathrm{n}$ \\
\hline 6.23.2: 47n., 83n., 164 & 14.62.2: 38n. \\
\hline 6.24.2: $83 \mathrm{n}$ & 15.6.3: 38n. \\
\hline 6.25.2: 96n. & 15.15.3: 47n. \\
\hline 6.29.4: 145,152 & 15.16.1: 32 \\
\hline 6.31-6.33: 8n. & 15.20.2-22.1: 37n. \\
\hline 6.33.1: $141 \mathrm{n}$. & 15.23.4: 37n. \\
\hline 6.36-6.37: 8n. & 15.38.1: 32 \\
\hline 6.38.1: 37n. & 15.41.1: 32 \\
\hline 6.38.2-3: 135 & 15.53.4: 32 \\
\hline 6.39.2: 8n. & 15.61.3: 31 \\
\hline 6.44.3: $132 \mathrm{n}$ & $15.65: 32$ \\
\hline 6.47.2: 166n. & 15.74.3: 31 \\
\hline 6.50.3: $103 \mathrm{n}$ & 16.6.1: 32,33 \\
\hline $6.51: 8 \mathrm{n}$ & 16.7.2: 166n. \\
\hline 6.51.1: 53n. & 16.14.1: 38n., 122n. \\
\hline 6.51.3: $115 \mathrm{n}$ & 16.21.1-22.5: 37n. \\
\hline *7.1.1: 26n. & 16.21.1: 38n. \\
\hline 11.11.1: 2 & 16.22.3: 31n. \\
\hline 11.24: 33 & 16.24.1-29.2: 37n. \\
\hline $11.27: 32$ & 16.33.2-35.2: 37n. \\
\hline 11.32.1: 47n. & $16.35: 3$ \\
\hline 11.34.1: 32 & 16.35.1: 157n. \\
\hline 12.10.1:38n. & Dialogus de Oratoribus \\
\hline 12.22.1: $122 \mathrm{n}$. & 1.1-2: 2 \\
\hline 12.24.2: 31 & $2.1: 2$ \\
\hline 12.25.1: $53 \mathrm{n}$ & Historiae \\
\hline $12.40 .5: 37 \mathrm{n}$ & 1.1.1-2: 28 \\
\hline 12.42.2: $145 \mathrm{n}$ & 1.1.1: $45 \mathrm{n}$. \\
\hline 12.67.1: 32 & 1.1.4: 177 \\
\hline 12.68.3: $122 \mathrm{n}$. & 3.25.2-3: 19n. \\
\hline
\end{tabular}


3.51: $19 \mathrm{n}$.

Historia Augusta

10.3: 1

Plínio-o-Moço

Epistulae

1.6: $2 \mathrm{n}$.

2.1.6: 2

2.11.17: $2 \mathrm{n}$

4.13.10: $2 \mathrm{n}$.

5.8.4: 19

5.8.5: $19 \mathrm{n}$.

6.16: 2

6.20: 2

7.20: 2

7.33.1: 2

$8.7: 2$

9.14: 173

9.23.2-3: $1 \mathrm{n}$.

Plínio-o-Velho

Naturalis Historia

7.76: 2

Plutarco

Aratus

49: 39n.

Políbio

12.25: $22 \mathrm{n}$.

Rhetorica ad Herennium

1.6.10: 19

1.8.13: 20, 23

Quintiliano

Institutio Oratoria

8.5.3: 30n.

10.1.31: 20,23

10.1.32: 20

10.1.33: 20

10.1.34: 20

Sidónio Apolinar

Epistulae

4.14.1: 1

4.22.2: 1

Suetónio

Iulius

73: $169 n$.

Vitrúvio

De Architectura

5.1: 120 


\section{Volumes publicados na ColecÇáo "Varia" - \\ SÉRIE MoNografiaS}

1. Mariana Montalvão Matias, Paisagens naturais e paisagens da alma no drama senequiano. "Troades" e "Thyestes" (Coimbra, CECH, 2009).

2. João Paulo Barros Almeida, Sentimento e conhecimento na poesia de Camilo Pessanha (Coimbra, CECH, 2009).

3. Cristina Santos Pinheiro, Opercurso de Dido, rainha de Cartago, na Literatura Latina (Coimbra, CECH, 2010).

4. Ricardo Nobre, Intrigas Palacianas nos Annales de Tácito. Processos e tentativas de obtenção de poder no principado de Tibério (Coimbra, CECH/CEC, 2010). 
Impressão:

Simões \& Linhares, Lda.

Av. Fernando Namora, n. ${ }^{\circ} 83$ Loja 4 3000 Coimbra 
Este estudo analisa o modo como o discurso de Tácito transmite e dota uma mensagem de significado em ambientes misteriosos de intriga. O mistério e a incerteza que ela evoca respondem, no geral, à busca de evasão que o leitor da Antiguidade procurava na historiografia. Nesta perspectiva, um escritor como Tácito labora num espaço limitado de informação, tematizando assuntos ligados às dicotomias revelação-ocultação e silêncio-palavra.

A informação dada explicitamente joga com o grau de conhecimento do leitor, que terá ainda a tarefa de interpretar omissões, sugestões, insinuações e implicações. De facto, porque utiliza mais implicações do que explicitações, Tácito enfatiza certos caracteres e incidentes, de modo a moldar a percepção e o entendimento que o leitor terá daquela informação no decorrer da narrativa. Para isso, o autor escolhe a focalização, o modo de representação do discurso (directo, indirecto, indirecto livre), e constrói isotopias, concretizadas por meio de encadeamentos de vocábulos não escolhidos ao acaso. Desta maneira, é possível apreciar, no campo da estética literária, as páginas dos Annales com um interesse constante, que a uariatio renova. 